DIEGO DOMINGOS DA SILVA

REMOÇÃO BIOLÓGICA DO NITROGÊNIO PELA VIA CURTA DE LIXIVIADO DE ATERRO SANITÁRIO OPERANDO UM REATOR EM BATELADAS SEQUENCIAIS (SBR) 


\title{
REMOÇÃO BIOLÓGICA DO NITROGÊNIO PELA VIA CURTA DE LIXIVIADO DE ATERRO SANITÁRIO OPERANDO UM REATOR EM BATELADAS SEQUENCIAIS (SBR)
}

\author{
Dissertação apresentada à Escola \\ Politécnica da Universidade de São Paulo \\ como parte dos requisitos para a \\ obtenção do título de Mestre em \\ Engenharia. \\ Área de Concentração: \\ Engenharia Hidráulica e Sanitária \\ Orientador: \\ Prof. Dr. Pedro Alem Sobrinho
}


Este exemplar foi revisado e alterado em relação à versão original, sob responsabilidade única do autor e com a anuência de seu orientador.

São Paulo, de junho de 2009.

Assinatura do autor

Assinatura do orientador

FICHA CATALOGRÁFICA

Silva, Diego Domingos da

Remoção biológica do nitrogênio pela via curta de lixiviado de aterro sanitário operando um reator em bateladas sequen ciais (SBR) / D.D. da Silva. -- ed.rev. -- São Paulo, 2009.

$164 \mathrm{p}$.

Dissertação (Mestrado) - Escola Politécnica da Universidade de São Paulo. Departamento de Engenharia Hidráulica e Sanitária.

1. Nitrogênio (Remoção) 2. Nitrificação 3. Resíduos sólidos I. Universidade de São Paulo. Escola Politécnica. Departamento de Engenharia Hidráulica e Sanitária II. t. 
A minha mãe Cleunice Cecareli, exemplo de força e perseverança, a meu Pai, Laércio Domingos e minhas irmãs Mileidy e Tatielly pelo apoio incondicional e alegria contagiante. 


\section{AGRADECIMENTOS}

A Deus, pela dádiva da vida.

Ao Professor Dr. Pedro Alem Sobrinho, por quem tenho profunda admiração profissional e pessoal, pela confiança, respeito e orientação firme e dedicada durante a condução deste trabalho.

À professora $\mathrm{Dr}^{\mathrm{a}}$. Dione Mari Morita, pelos ensinamentos e contribuições de fundamental importância a este trabalho.

Ao professor Dr. Roque Passos Piveli, pelo apoio, confiança e ensinamentos durante esta pesquisa.

Ao amigo Luciano Mattos Queiroz pela ajuda, compreensão e ensinamentos imprescindíveis à realização deste trabalho.

Aos grandes amigos e companheiros Humberto Carlos Ruggeri e Rodrigo Cezar Monteiro, pela amizade, respeito, compreensão e incentivo ao longo do mestrado.

À amiga Fernanda Maria Urquieta pelo respeito, carinho e conselhos destinados a mim.

À colega Mailer Sene Amaral, pela paciência e companheirismo nas horas de laboratório.

Aos companheiros de laboratório, Lúcia, Aline (em memória), Gilberto, Bárbara e Simone.

Ao amigo de república Diogo Carlos Bernardes de Souza pelo apoio, amizade e companheirismo nas horas de estudo e nos momentos de descontração.

Ao grande amigo Daniel Rodolfo Medeiros Gerding, pelos ensinamentos e apoio nas horas difíceis.

Ao meu cunhado José Francisco Pires Junior, pelo apoio e dedicação incondicional.

Aos funcionários do Laboratório de Saneamento da Poli-USP, Fábio Campos e Laerte Carvalho, pela fundamental ajuda e respeito.

Aos funcionários Ricardo Souza, Ângela Mizuta, Odorico Borges, lara Raposo pela eficiência e respeito sempre dispensados a mim.

À CAPES pelo fornecimento da bolsa de auxílio.

A companhia de saneamento do estado de São Paulo (SABESP), pelo fornecimento do lixiviado de aterro.

À Fundação de Amparo a Pesquisa do Estado de São Paulo - FAPESP, pelo apoio financeiro. 
A todos os Brasileiros que através de sua contribuição, muitas vezes injusta, me proporcionaram estudar em uma universidade de qualidade. 
SILVA, D.D. Remoção biológica do nitrogênio pela via curta de lixiviado de aterro sanitário operando um reator em bateladas sequenciais (SBR). 2009. 198 f. Dissertação (Mestrado) - Escola Politécnica da Universidade de São Paulo, São Paulo - SP.

\section{RESUMO}

O presente trabalho avaliou a remoção do nitrogênio amoniacal de liquido percolado de aterro sanitário através do processo de nitritação/desnitritação (via curta) utilizando a própria matéria orgânica presente no lixiviado como fonte de carbono para o processo de desnitritação. Foi também avaliada a remoção de nitrogênio amoniacal do lixiviado através do processo de "stripping" de amônia. Para o processo de "stripping" foram utilizados dois sistemas, o primeiro era constituído por um reator (R-2) com volume útil de $20 \mathrm{~L}$ mantido sobre agitação mecânica (palheta) e o segundo era composto de uma coluna cilíndrica, com volume de lixiviado de 10L, mantida sob aeração. Além da remoção de nitrogênio houve também uma diminuição na concentração de DQO, DBO e COT durante os ciclos de "stripping". A taxa volumétrica de remoção de amônia durante os ciclos de "stripping" variou entre 78 e 86,95 mg N-NH$/$ L.dia. Para a avaliação da remoção de nitrogênio através da via curta (via nitrito), foi utilizado um reator operado em bateladas seqüenciais (SBR1) com volume útil de $20 \mathrm{~L}$. O reator foi operado por um período de aproximadamente 1 ano. A avaliação do processo de nitritação/desnitritação se deu em 4 fases distintas; na primeira fase o sistema foi alimentado com $2 \mathrm{~L}$ de lixiviado bruto, na segunda fase o sistema $\mathrm{R}-1$ foi alimentado com lixiviado pré tratado $(\mathrm{N}$ $\mathrm{NH}_{3 \text { lixiviado }} \cong 1200 \mathrm{mg} / \mathrm{L}$ ), na fase três o sistema foi também alimentado com $2 \mathrm{~L}$ de percolado pré-tratado $\left(\mathrm{N}-\mathrm{NH}_{3 \text { lixiviado }} \cong 900 \mathrm{mg} / \mathrm{L}\right)$ e por fim, na fase 40 sistema foi alimentado com $4 \mathrm{~L}$ de lixiviado pré-tratado $\left(\mathrm{N}-\mathrm{NH}_{3 \text { lixiviado }} \cong 900 \mathrm{mg} / \mathrm{L}\right.$ ). Nas duas primeiras fases da pesquisa a remoção de nitrogênio foi relativamente eficiente, variando entre 80 e 90\%, porém mesmo com a concentração de amônia livre variando entre 0,18 e 20,7 mg/L não houve a inibição da nitratação durante a etapa aerada dos ciclos de tratamento. Durante as fases 1 e 2, a fase anóxica foi relativamente longa sendo que, as taxas específicas de desnitritação variaram entre 0,0100 e 0,0148 $\mathrm{Kg} \mathrm{NO}_{3}^{-}, \mathrm{NO}_{2}^{-} / \mathrm{Kg}$ SSV.dia. $\mathrm{Na}$ fase 3, após a mudança na alimentação do sistema, o reator R-1 entrou em regime de equilíbrio e a inibição da nitratação foi praticamente total (acima de 95\%). Mesmo com a completa inibição da nitratação, a etapa anóxica durante os ciclos de tratamento da fase 3 continuou sendo relativamente longa (72 h em média) remetendo assim, a uma falta de matéria orgânica para a redução do nitrito durante a fase anóxica. Na fase 4, apesar da não inibição da nitratação durante os primeiros ciclos, nos ciclos que se seguiram a inibição foi quase total, demonstrando claramente a adaptação do sistema às condições necessárias ao acúmulo de nitrito. A manutenção do $\mathrm{pH}$ da massa líquida próximo a 8,3 foi determinante para o acúmulo de nitrito durante todas as fases da pesquisa. Nas fases 1 e 2 houve a necessidade de controle do $\mathrm{pH}$ com adição de alcalinizante, já nas fases 3 e 4 esse controle não foi necessário. 
SILVA, D.D Biological Nitrogen removal through nitritation of landfill leachate operating a sequencing batch reactor (SBR). 2009. $198 \mathrm{f}$. Thesis (Master's) Escola Politécnica da Universidade de São Paulo, São Paulo - SP.

\section{ABSTRACT}

The present work evaluates the biological ammonia removal of a landfill leachate, through nitritation/denitritation as well as the utilization of the organic compounds present in the landfill leachate, as carbon source to denitritation process. It also evaluates the ammonia removal of landfill leachate by the ammonia stripping process. It has been used two systems for the stripping process, the first one was constituted of a reactor (R-2) with $20 \mathrm{~L}$ useful volume kept on mechanical shaking (vane) and the second one was composed of a cylindrical column, with a $10 \mathrm{~L}$ of landfill leachate volume, kept on aeration. Beyond the biological ammonia removal it also had a reduction in the COD, BOD and TOC concentration during the stripping cycles. The ammonia removal volumetric rate during the stripping cycles have varied between 78 e $86,95 \mathrm{mg} \mathrm{N}-\mathrm{NH}_{3} / \mathrm{L}$.day. In order to evaluate the ammonia removal through the short cut (via nitrite) one has used a sequencing batch reactor (SBR-1) with a $20 \mathrm{~L}$ useful volume. The reactor was been operated by a period of approximately 1 year. The assessment of nitritation/denitritation process has happened in 4 distinct phases: in the first one the system was fed on $2 \mathrm{~L}$ of heavy landfill leachate; in the second the system R-1 was fed on pre-treated landfill leachate $\left(\mathrm{N}-\mathrm{NH}_{3 \text { leachate }} \cong 1200 \mathrm{mg} / \mathrm{L}\right)$; in the third phase the system was also fed on $2 \mathrm{~L}$ of pre-treated landfill leachate $\left(\mathrm{N}-\mathrm{NH}_{3 \text { leachate }} \cong 900 \mathrm{mg} / \mathrm{L}\right)$; and finally, in the fourth phase it was fed on $4 \mathrm{~L}$ of pre-treated landfill leachate $\left(\mathrm{N}^{-\mathrm{NH}_{3} \text { leachate }} \cong 900 \mathrm{mg} / \mathrm{L}\right)$. In the two first phases of this research the biological ammonia removal was been relatively efficient, varying between 80 and $90 \%$, however, even with the free ammonia varying between 0,18 and $20,70 \mathrm{mg} / \mathrm{L}$, it has not had nitratation inhibition during the aerated stage of the treatment cycles. During phases 1 and 2 the anoxic phase was relatively long and specific denitritation rates have varied between 0,0100 and $0,0148 \mathrm{Kg} \mathrm{NO}_{3}{ }^{-}, \mathrm{NO}_{2}{ }^{-} / \mathrm{Kg} \mathrm{VSS}$.day. In phase 3, after the change of system feeding, the R-1 reactor has entered in balance regime and the nitratation inhibition has been practically total (above 95\%). Even with the complete nitratation inhibition, the anoxic phase during the phase 3 treatment cycles have continued being relatively long (72h on average), thus sending to a lack of organic compounds for the nitrite reduction in this phase. In phase 4 , although the not inhibition of nitratation during the first cycles, in the followed cycles the inhibition has been almost total, demonstrating clearly the system adaptation to the necessary conditions to the nitrite accumulation. The maintenance of $\mathrm{pH}$ of liquid mass next to 8,3 has been determinative for the accumulation of nitrite during all phases of this research. In phases 1 and 2 it have been necessary to control the $\mathrm{pH}$ alkalinizing the system, already in phases 3 and 4 this control has not been necessary. 


\section{ÍNDICE}

FICHA CATALOGRÁFICA

1 INTRODUÇÃO

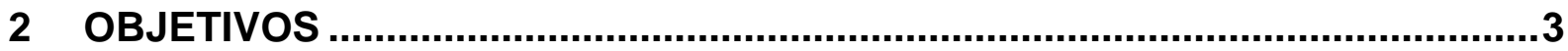

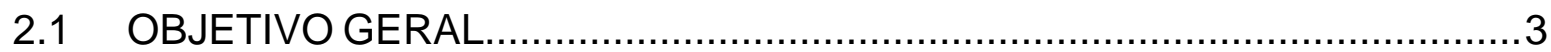

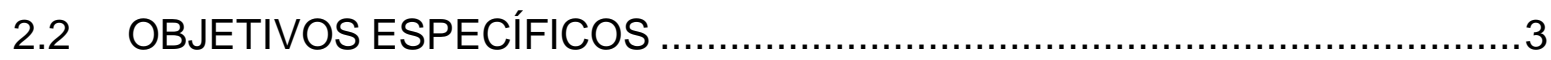

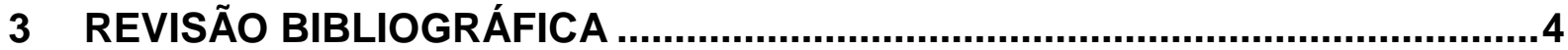

3.1 PRINCIPÍOS GERAIS DE ATERRO SANITÁRIO....................................

3.2 PRINCÍPIOS GERAIS DA DECOMPOSIÇÃO EM ATERROS SANITÁRIOS .......................6

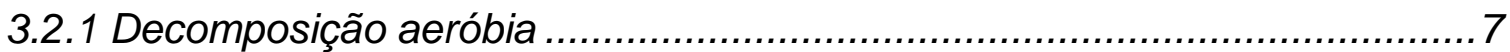

3.2.2 Fase acetogênica (anaeróbia) ........................................................ 8

3.2.3 Decomposição anaeróbia (metanogênese) ……..................................

3.3 CARACTERISTICAS GERAIS DA DISPOSIÇÃO DO LIXO NO BRASIL.........9

3.4 GERAÇÃO E CARACTERÍSTICAS DO LIXIVIADO DE ATERRO SANITÁRIO 11

3.4.1 Fatores que afetam a qualidade do lixiviado........................................... 13

3.4.1.1 Variações temporais no lixiviado ..............................................15

3.5 TRATAMENTO DE LIQUIDOS PERCOLADOS DE ATERRO ......................16

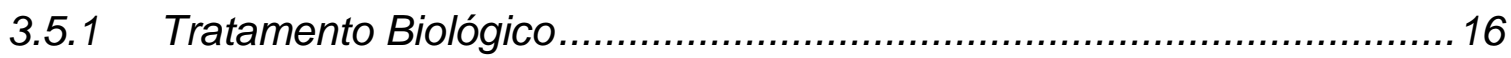

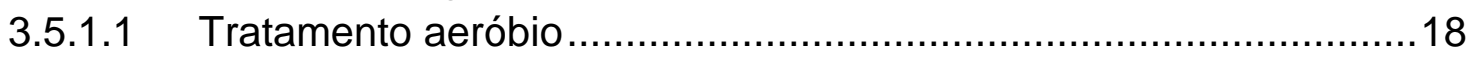

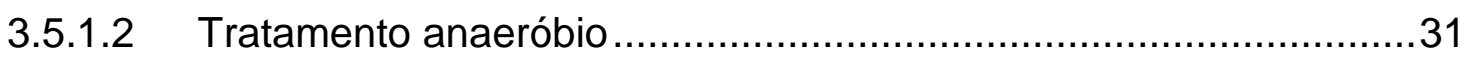

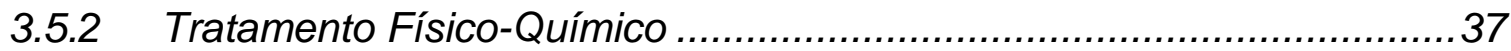

3.5.3 Tratamento do lixiviado juntamente com esgoto doméstico ..................43

3.5.4 Uso do aterro como um bioreator .......................................................4

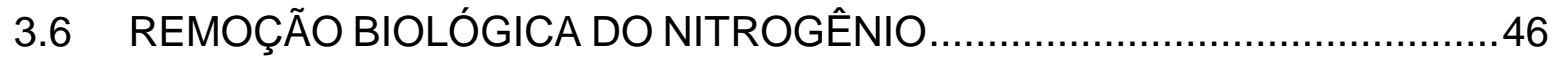

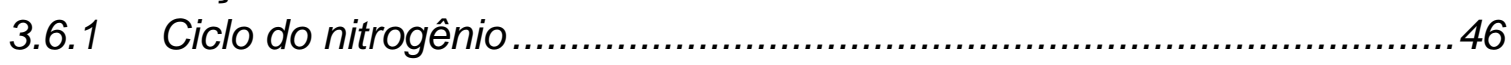

3.6.2 Problemas causados pelo lançamento de nitrogênio em águas naturais 47

3.6.3 Controle do nitrogênio perante a legislação ........................................48

3.6.4 Remoção biológica do nitrogênio presente em águas residuárias..........50

3.6.4.1 Remoção biológica do nitrogênio via nitrito .......................................54

3.6.4.2 Acúmulo de nitrito em sistemas biológicos de tratamento de efluentes

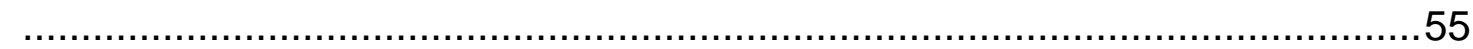

3.6.5 Processos alternativos para a remoção do nitrogênio ..........................58

3.6.5.1 Processo SHARON (Single Reactor High Activity Ammonia Removal

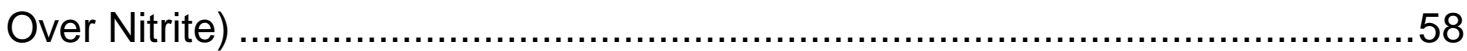

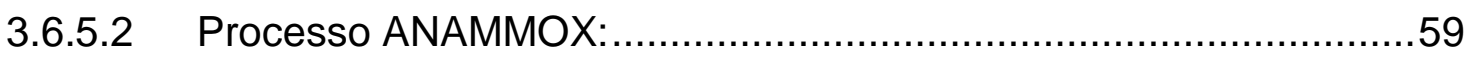

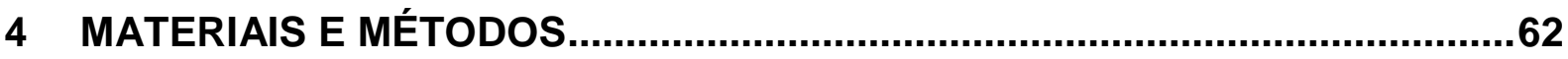

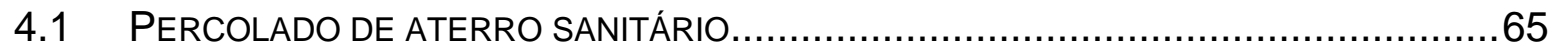




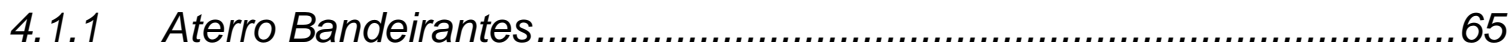

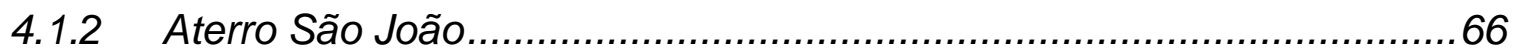

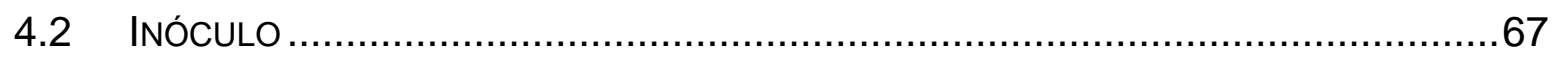

4.3 PRÉ-TRATAMENTO FíSICO DO LIXIVIADO DE ATERRO SANITÁRIO .........................67

4.3.1 Pré-tratamento do lixiviado por "stripping" de amônia com agitação

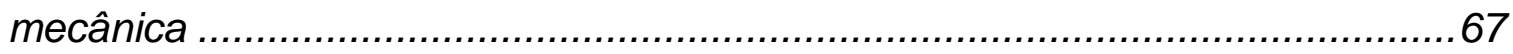

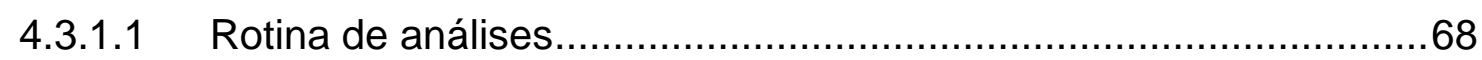

4.3.2 Pré-tratamento do lixiviado por "stripping" de amônia com sistema de aeração69

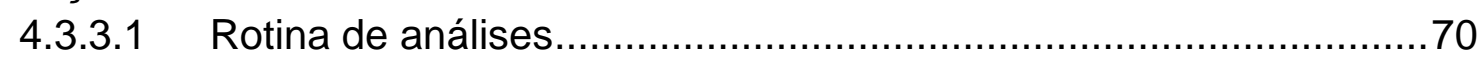

4.4 SISTEMA EM BATELADAS SEQÜENCIAIS (R-1) ......................................... 71

4.4.1 Etapa 01 - Utilização do lixiviado bruto para alimentação do sistema 71

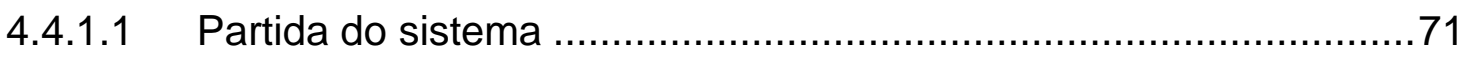

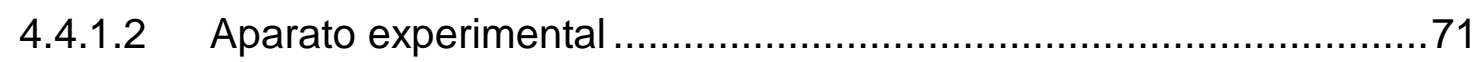

4.4.1.3 Procedimentos de rotina ...........................................................

4.4.1.4 Operação do sistema ................................................................

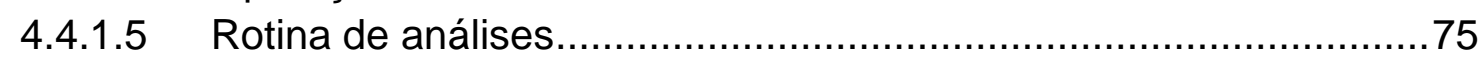

4.4.2 Fase 02 - Utilização do lixiviado pré-tratado ("stripping" de amônia do lixiviado bruto até a concentração de $1200 \mathrm{mg}-\mathrm{N}-\mathrm{NH}_{4} / \mathrm{L}$ ) para a alimentação do sistema 77

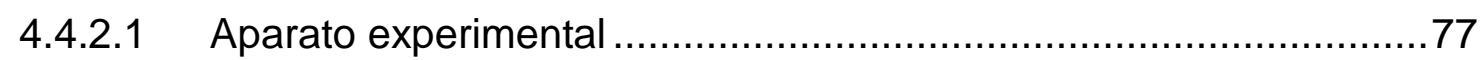

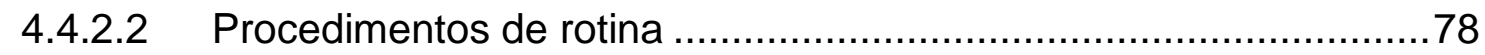

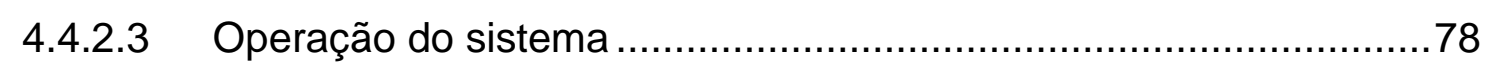

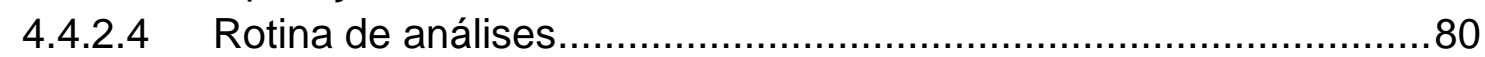

4.4.3 Fase 03 - Utilização do lixiviado pré-tratado ("stripping" de amônia do lixiviado bruto até a concentração de $900 \mathrm{mg} \mathrm{N}-\mathrm{NH}_{3} / \mathrm{L}$ ) para a alimentação do sistema 81

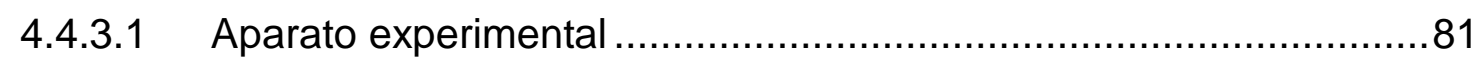

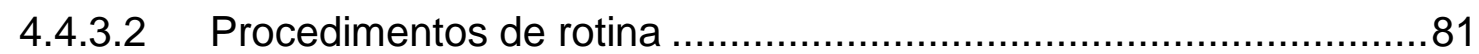

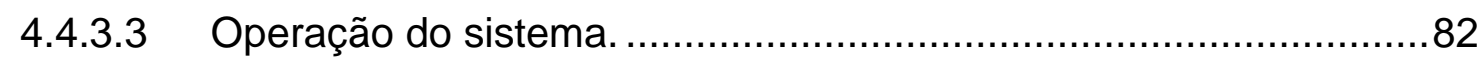

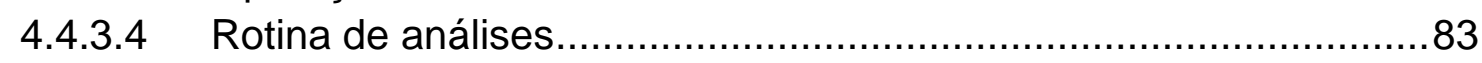

4.4.4 Fase 04 - Utilização do lixiviado pré-tratado ("stripping" de amônia do lixiviado bruto até a concentração de $900 \mathrm{mg} \mathrm{N}-\mathrm{NH}_{4} / \mathrm{L}$ ) para a alimentação do

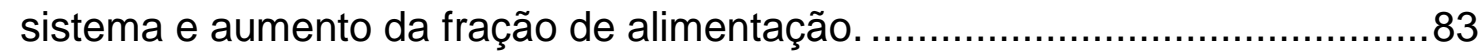

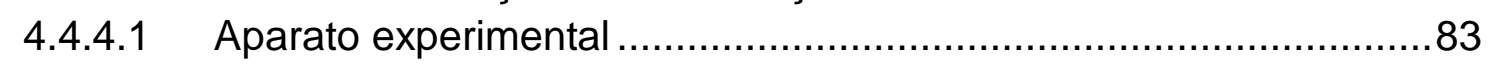

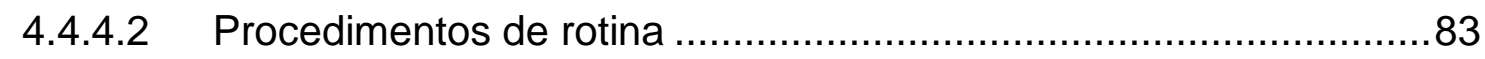

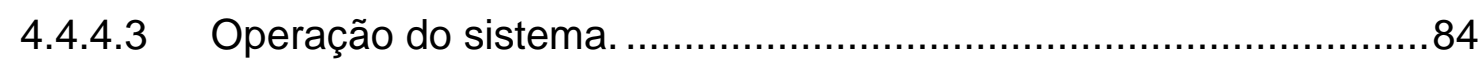

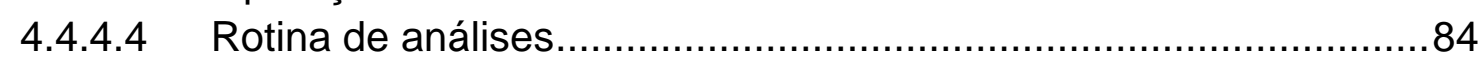

4.5 CÁlCULO DO BALANÇO DE MASSA EXECUTADO DURANTE A PESQUISA (SISTEMA R-1) 84

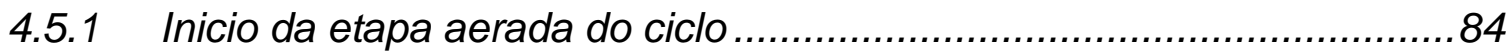

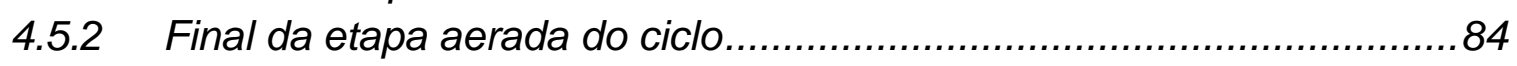

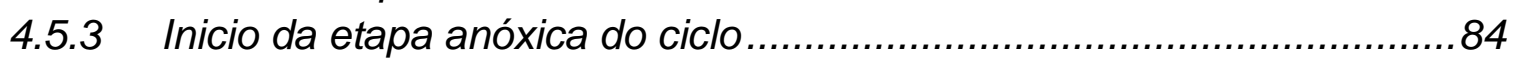




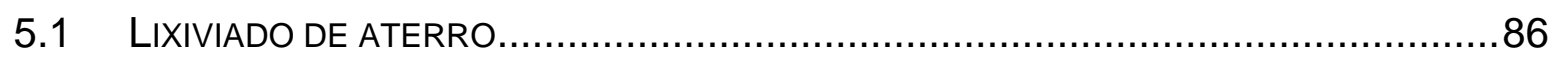

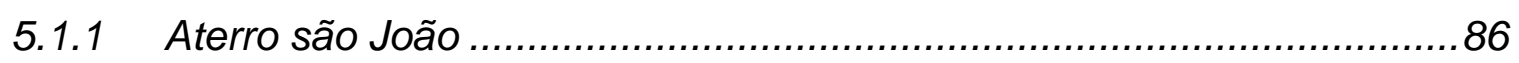

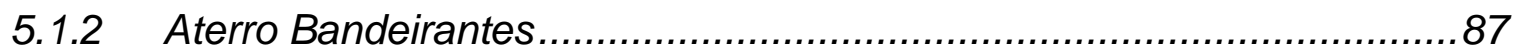

5.2 PRÉ-TRATAMENTO Fí́SICO DO LIXIVIADO DE ATERRO SANITÁRIO ...........................88

5.2.1 Pré-tratamento do lixiviado por "stripping" de amônia com agitação mecânica

5.2.1.1 Concentração do nitrogênio amoniacal no final do "stripping" igual a

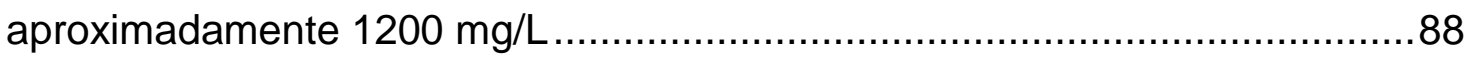

5.2.1.2 Concentração do nitrogênio amoniacal no final do "stripping" igual a

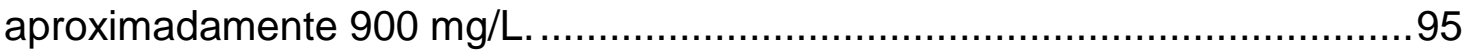

5.2.2 Pré-tratamento do lixiviado por "stripping" de amônia com sistema de aeração 105

5.2.2.1 Concentração do nitrogênio amoniacal no final do "stripping" igual a aproximadamente $1200 \mathrm{mg} / \mathrm{L}$ 105

5.2.2.2 Concentração do nitrogênio amoniacal no final do "stripping" igual a

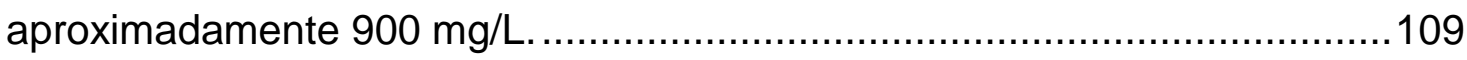

5.3 SISTEMA EM BATELADAS SEQÜENCIAIS (R-1) ...........................................119

5.3.1 Fase 01 - Alimentação do sistema utilizando lixiviado bruto - Partida do sistema 119

5.3.2 Fase 02 - alimentação do sistema com lixiviado pré-tratado ("stripping" de amônia até a concentração de aproximadamente $1200 \mathrm{mg} / \mathrm{L}$ )..... 125 5.3.3 Fase 03 - alimentação do sistema com lixiviado pré-tratado ("stripping" de amônia até a concentração de aproximadamente $900 \mathrm{mg} / \mathrm{L}$ )..... 133 5.3.4 Fase 04 - alimentação do sistema com $4 L$ de lixiviado pré-tratado ("stripping" de amônia até a concentração de aproximadamente 900 mg/L).... 149

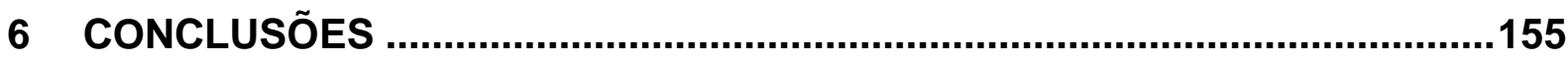

7 SUGESTÕES PARA PRÓXIMAS PESQUISAS …......................................157

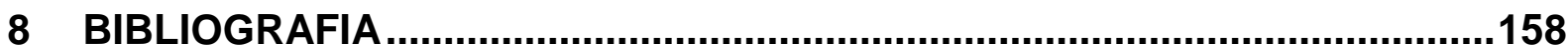




\section{LISTA DE FIGURAS}

Figura 5 - Representação esquemática de um reator UASB. Fonte: Adaptado de

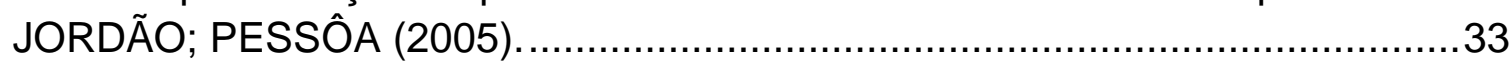

Figura 8 - Vista aérea do aterro Bandeirantes. Fonte: MELLIS, 2004 .....................65

Figura 9 - Desenho esquemático do sistema R-2 ….........................................68

Figura 10 - Desenho esquemático do sistema COL-1 ..........................................70

Figura 13 - Desenho esquemático do aparato experimental utilizado na segunda

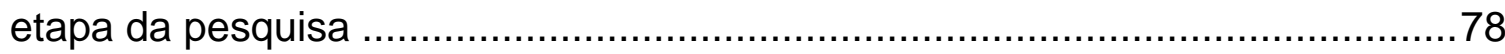

Figura 14 - Desenho esquemático da operação dos ciclos de tratamento do sistema R-1 na

Figura 17 - Perfis temporais das concentrações de $\mathrm{DQO}$ e N-NH${ }_{3}$ durante os ciclos de "stripping" da primeira fase - Sistema R-2.

Figura 18 - Variação temporal do $\mathrm{pH}$ do lixiviado durante o primeiro ciclo de "stripping" (sistema R-2/Fase 1).

Figura 19 - - Variação temporal da alcalinidade total do lixiviado durante o primeiro ciclo de "stripping" (sistema R-2/Fase 1). ...................................................91

Figura 20 - Perfis das concentrações de $\mathrm{N}^{-\mathrm{NH}_{3}}$ durante os ciclos de "stripping" do lixiviado provindo do aterro São João - concentração de $\mathrm{N}_{-} \mathrm{NH}_{3}$ final de aproximadamente $1200 \mathrm{mg} / \mathrm{L}$.

Figura 21 - Concentrações médias de $\mathrm{N}^{-\mathrm{NH}_{3}}$ durante os ciclos 1,4 e 5 de "Stripping" - Aterro São João.

Figura 22 - Perfis das concentrações de $\mathrm{N}^{-\mathrm{NH}_{3}}$ durante os ciclos de "stripping" do lixiviado provindo do aterro Bandeirantes - concentração de $\mathrm{N}-\mathrm{NH}_{3}$ final de aproximadamente $1200 \mathrm{mg} / \mathrm{L}$

Figura 23 - Concentrações médias de $\mathrm{N}-\mathrm{NH}_{3}$ durante os ciclos de "Stripping" - Aterro Bandeirantes

Figura 24 - Perfis temporais da concentração de DQO dos primeiros 4 primeiros ciclos de "stripping" do lixiviado bruto (sistema R-2)......................................98

Figura 25 - Perfis temporais da concentração de DQO dos primeiros 4 ciclos seguintes de "stripping" do lixiviado bruto (sistema R-2). .................................99

Figura 26 - Perfis temporais das concentrações de DQO e COT dos 4 ciclos seguintes de "stripping" do lixiviado bruto (sistema R-2). ................................99

Figura 27 - Perfis temporais das concentrações de DQO e COT dos 4 ciclos seguintes de "stripping" do lixiviado bruto (sistema R-2)................................100

Figura 28 - Perfis temporais das concentrações de DQO e COT dos 4 últimos ciclos de "stripping" do lixiviado bruto (sistema R-2).

Figura 29 - Variação temporal do $\mathrm{pH}$ do lixiviado durante o primeiro ciclo de "stripping" (sistema R-2/Fase 2). 102

Figura 30 - Variação temporal da alcalinidade total do lixiviado durante o primeiro

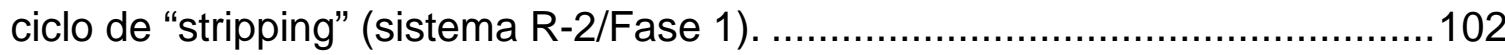

Figura 31 - Perfis das concentrações de $\mathrm{N}-\mathrm{NH}_{3}$ durante os 20 ciclos de "stripping". 
Figura 32 - Concentrações médias de $\mathrm{N}^{-\mathrm{NH}_{3}}$ durante os ciclos de "Stripping" Sistema R-2

Figura 33 - Perfis temporais das concentrações de $\mathrm{DQO}$ e N-NH${ }_{3}$ durante os ciclos de "stripping" da primeira fase - Sistema COL-1

Figura 34 - Perfis das concentrações de $\mathrm{N}^{-\mathrm{NH}_{3}}$ durante os ciclos de "stripping" do lixiviado provindo do aterro São João - concentração de $\mathrm{N}_{-} \mathrm{NH}_{3}$ final de aproximadamente $1200 \mathrm{mg} / \mathrm{L}$.

Figura 35 - Perfis das concentrações de $\mathrm{N}-\mathrm{NH}_{3}$ durante os ciclos de "stripping" do lixiviado provindo do aterro Bandeirantes - concentração de $\mathrm{N}-\mathrm{NH}_{3}$ final de aproximadamente $1200 \mathrm{mg} / \mathrm{L}$.

Figura 36 - Concentrações médias de N-NH3 durante os ciclos de "Stripping" Aterro São João.

Figura 37 - Concentrações médias de $\mathrm{N}-\mathrm{NH}_{3}$ durante os ciclos de "stripping" - Aterro Bandeirantes.

Figura 38 - Perfis temporais das concentrações de DQO dos 4 primeiros ciclos de "stripping" do lixiviado bruto (sistema COL-1).

Figura 39 - Perfis temporais das concentrações de DQO dos 4 ciclos seguintes de "stripping" do lixiviado bruto (sistema COL-1).

Figura 40 - Perfis temporais das concentrações de DQO e COT dos 4 ciclos seguintes de "stripping" do lixiviado bruto (sistema COL-1).....

Figura 41 - Perfis temporais das concentrações de DQO e COT dos 4 ciclos seguintes de "stripping" do lixiviado bruto (COL-1).

Figura 42 - Perfis temporais das concentrações de DQO e COT dos 4 últimos ciclos de "stripping" do lixiviado bruto (sistema COL-1).

Figura 43 - Variação temporal do $\mathrm{pH}$ do lixiviado durante o primeiro ciclo de "stripping" (sistema COL-1/Fase 2).

Figura 44 - Variação temporal da concentração de alcalinidade do lixiviado durante 0 primeiro ciclo de "stripping" (sistema COL-1/Fase 2).

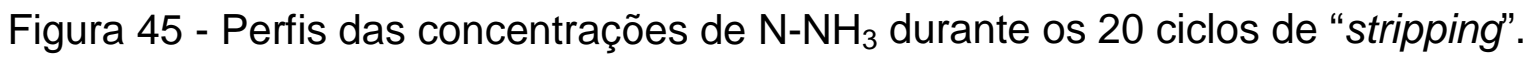

Figura 46 - Concentrações médias de $\mathrm{N}-\mathrm{NH}_{3}$ durante os ciclos de "Stripping" Sistema COL-1.

Figura 47 - Perfis temporais das concentrações de $\mathrm{DBO}, \mathrm{N}^{-\mathrm{NO}_{2}}{ }^{-} \mathrm{N}_{-} \mathrm{NO}_{3}{ }^{-}$e N-NH${ }_{3}+$ durante o primeiro ciclo de tratamento do reator R-1/Fase 1 - Aterro São João.

Figura 48 - Perfis temporais das concentrações de $\mathrm{DBO}, \mathrm{N}^{-\mathrm{NO}_{2}}{ }^{-}, \mathrm{N}_{-} \mathrm{NO}_{3}{ }^{-}$e N-NH${ }_{3}+$ durante o segundo ciclo de tratamento do reator R-1/Fase 1 - Aterro Bandeirantes.

Figura 49 - Perfis temporais das concentrações de $\mathrm{DBO}, \mathrm{N}_{-} \mathrm{NO}_{2}^{-}, \mathrm{N}_{-} \mathrm{NO}_{3}^{-}$e N-NH${ }_{3}^{+}$ durante o ultimo ciclo de tratamento do reator R-1/Fase1 - Aterro Bandeirantes.

Figura 50- Perfis temporais das concentrações de $\mathrm{DBO}, \mathrm{N}_{-} \mathrm{NO}_{2}{ }^{-}, \mathrm{N}^{-\mathrm{NO}_{3}}{ }^{-}$e N- $\mathrm{NH}_{3}+$ durante o primeiro ciclo de tratamento do reator R-1/Fase 2 - Aterro São João. 
Figura 51 - Perfis temporais das concentrações de $\mathrm{DBO}, \mathrm{N}-\mathrm{NO}_{2}{ }^{-}, \mathrm{N}-\mathrm{NO}_{3}{ }^{-}$e $\mathrm{N}-\mathrm{NH}_{3}+$ durante o segundo ciclo de tratamento do reator R-1/Fase 2 - Aterro Bandeirantes. 128

Figura 52 - Perfis temporais das concentrações de $\mathrm{DBO}, \mathrm{N}-\mathrm{NO}_{2}^{-}, \mathrm{N}-\mathrm{NO}_{3}{ }^{-}$e N-NH${ }_{3}^{+}$ durante o terceiro ciclo de tratamento do reator $\mathrm{R}-1 /$ Fase 2 - Aterro Bandeirantes. 129

Figura 53 - Perfis temporais das concentrações de $\mathrm{DBO}, \mathrm{N}-\mathrm{NO}_{2}^{-}, \mathrm{N}_{-} \mathrm{NO}_{3}{ }^{-}$e $\mathrm{N}-\mathrm{NH}_{3}+$ durante o quarto ciclo de tratamento do reator R-1/Fase 2 - Aterro São João. 130

Figura 54 - Perfis temporais das concentrações de $\mathrm{DBO}, \mathrm{N}-\mathrm{NO}_{2}^{-}, \mathrm{N}-\mathrm{NO}_{3}^{-}$e N-NH${ }_{3}+$ durante o quinto ciclo de tratamento do reator R-1/Fase 2 - Aterro São João. 131

Figura 55 - Perfis temporais das concentrações de $\mathrm{DBO}, \mathrm{N}-\mathrm{NO}_{2}{ }^{-}, \mathrm{N}-\mathrm{NO}_{3}{ }^{-}$e $\mathrm{N}-\mathrm{NH}_{3}+$ durante os dois primeiros ciclos de tratamento do reator $\mathrm{R}-1 /$ Fase 3 - Aterro Bandeirantes.

Figura 56 - Perfil da concentração de alcalinidade durante a etapa anóxica do segundo ciclo de tratamento - Fase3.

Figura 57 - Perfis das concentrações de $\mathrm{N}^{-N \mathrm{~N}_{2}}{ }^{-}$durante os 10 primeiros ciclos de tratamento - Fase 3

Figura 58 - Perfis das concentrações de $\mathrm{N}_{-} \mathrm{NO}_{2}{ }^{-}$durante os 10 últimos ciclos de tratamento - Fase 3

Figura 59 - Concentrações médias de $\mathrm{N}^{-N_{2}}{ }_{2}^{-}$durante a etapa anóxica dos 10 primeiros ciclos de tratamento do sistema R-1 - Fase 3.

Figura 60 - Concentrações médias de $\mathrm{N}-\mathrm{NO}_{2}{ }^{-}$durante a etapa anóxica dos 10 últimos ciclos de tratamento do sistema R-1 - Fase 3.

Figura 61 - Variação da concentração de $\mathrm{N}-\mathrm{NO}_{2}{ }^{-}$durante a fase anóxica dos 10 primeiros ciclos de tratamento do reator R-1 - fase 3 .

Figura 62 - Variação da concentração de N-NO2- durante a fase anóxica dos 10 ultimos ciclos de tratamento do reator R-1 - fase 3 .

Figura 63 - Perfis das concentrações de COT durante os 10 últimos ciclos de tratamento - Fase 3

Figura 64 - Perfis temporais das concentrações de $\mathrm{N}-\mathrm{NO}_{2}{ }^{-}, \mathrm{N}-\mathrm{NO}_{3}{ }^{-}$e $\mathrm{N}-\mathrm{NH}_{3}+$ durante o primeiro ciclo de tratamento do reator $\mathrm{R}-1 / \mathrm{Fase} 4$.

Figura 65 - Perfis temporais das concentrações de $\mathrm{N}_{-} \mathrm{NO}_{2}{ }^{-}, \mathrm{N}-\mathrm{NO}_{3}{ }^{-}$e $\mathrm{N}-\mathrm{NH}_{3}+$ durante os dois ciclos seguintes de tratamento do reator $\mathrm{R}-1 /$ Fase 4.

Figura 66- Perfis temporais das concentrações de $\mathrm{N}-\mathrm{NO}_{2}^{-}, \mathrm{N}-\mathrm{NO}_{3}{ }^{-}$e N-NH $\mathrm{NH}_{3}+$ durante os dois ciclos finais de tratamento do reator $\mathrm{R}-1 /$ Fase 4 . 


\section{LISTA DE TABELAS}

Tabela 1 - Etapas do processo de lodos ativados em bateladas. ............................23

Tabela 2 - Padrões de qualidade das formas de nitrogênio para os cursos d'água ..49

Tabela 3 - Padrões de lançamento para as formas do nitrogênio para corpos d'água classe 2 no estado de São Paulo

Tabela 4 - Cronograma de alimentação do sistema R-1 de acordo com o lixiviado utilizado.

Tabela 5 - Freqüência de amostragem e métodos analíticos dos ciclos de "stripping" para o sistema R-2

Tabela 6 - Freqüência de amostragem e métodos analíticos dos ciclos de tratamento da primeira fase da pesquisa. .76

Tabela 7 - Freqüência de amostragem e métodos analíticos dos ciclos de tratamento da segunda fase da pesquisa....

Tabela 8 - Características físico-químicas do lixiviado do aterro São João 86

Tabela 9 - Características físico-químicas do lixiviado do aterro Bandeirantes..........87

Tabela 10 - Características físico-químicas do lixiviado durantes os ciclos de "stripping"......

Tabela 11 - Características físico-químicas do lixiviado durantes os ciclos de "stripping".

Tabela 12 - Características físico-químicas do lixiviado durantes os ciclos de "stripping".

Tabela 13 - Características físico-químicas do lixiviado durantes os ciclos de "stripping"......

Tabela 14 - Características físico-químicas e taxas do primeiro ciclo de tratamento utilizando o sistema R-1 (primeira fase - aterro São João)

Tabela 15 - Características físico-químicas e taxas do segundo ciclo de tratamento utilizando o sistema R-1 (primeira fase - aterro Bandeirantes) .

Tabela 16 - Características físico-químicas e taxas do ultimo ciclo de tratamento utilizando o sistema R-1 (primeira fase - aterro Bandeirantes) .

Tabela 17 - Características físico-químicas e taxas do primeiro ciclo de tratamento utilizando o sistema R-1 (segunda fase - Aterro São João).

Tabela 18 - Características físico-químicas e taxas do segundo ciclo de tratamento utilizando o sistema R-1 (segunda fase - Aterro Bandeirantes).

Tabela 19 - Características físico-químicas e taxas do terceiro ciclo de tratamento utilizando o sistema R-1 (segunda fase - Aterro Bandeirantes).

Tabela 20 - Características físico-químicas e taxas do quarto ciclo de tratamento utilizando o sistema R-1 (segunda fase - Aterro São João).

Tabela 21 - Características físico-químicas e taxas do quinto ciclo de tratamento utilizando o sistema R-1 (segunda fase - Aterro São João).

Tabela 22 - Características físico-químicas e taxas dos 2 primeiros ciclos de tratamento utilizando o sistema R-1 (terceira fase). 
Tabela 23 - Características físico-químicas e taxas referentes aos 20 ciclos de tratamento utilizando o sistema R-1 (terceira fase).

Tabela 24 - Características físico-químicas e taxas referentes aos 5 ciclos de tratamento utilizando o sistema R-1 (quarta fase). 153 


\section{LISTA DE ABREVIATURAS E SIGLAS}
A/M
Relação Alimento/Microrganismos
ANAMMOX
Anaerobic Ammonium Oxidation
APHA
American Public Health Association
AWWA
American Water Works Association
CETESB
Companhia de Tecnologia de Saneamento Ambiental
CONAMA
Conselho Nacional do Meio Ambiente
DBO
Demanda Bioquímica de Oxigênio
DQO
Demanda Química de Oxigênio
COT
Carbono Orgânico Total
ETA
Estação de Tratamento de Água
ETE
Estação de Tratamento de Esgoto
h
horas
kg
kilograma
$\mathbf{L}$
litros
mg
miligrama
$\mathrm{mL}$
mililitro
N.T
Nitrogênio Total
O.D.
Oxigênio Dissolvido
OLAND
Oxygen-limited autotrophic nitrification denitrification
pH
Potencial Hidrogeniônico
SBR
Sequencing Batch Reactor
R-1
Reator 1
R-2
Reator 2
COL-1
Coluna 1
SHARON
Single Rector High Activity Ammonia Removal Over Nitrite
S.M.A.
Secretaria de Meio Ambiente
S.N.D.
Simultaneous Nitrification and Denitrification
SS
Sólidos em Suspensão
SST
Sólidos em Suspensão Totais
SSV
Sólidos em Suspensão Voláteis
$\mathbf{T}$
Temperatura
TDH
Tempo de Detenção Hidráulico 
UASB

USP

USEPA

UV

WEF
Upflow Anaerobic Sludge Bioreactor

Universidade de São Paulo

United States Environmental Protect Agency

Ultra Violeta

Water Environment Federation 


\section{LISTA DE SÍMBOLOS}

C Graus Celsius

$\mathbf{e}^{-} \quad$ Elétron livre

Ka Constante de ionização da amônia na condição de equilíbrio

Kb Constante de ionização do nitrito na condição de equilíbrio

Kw Constante de ionização da água

Ko Constante de saturação em termos de oxigênio

$\boldsymbol{\mu}_{\text {máx }}$ Velocidade máxima específica de crescimento

$\boldsymbol{\mu} \quad$ Velocidade específica de crescimento

N Relativo ao símbolo do elemento nitrogênio

$\mathbf{N}-\mathrm{NO}_{\mathbf{x}} \quad$ nitrito + nitrato

$\% \quad$ Porcentagem 


\section{INTRODUÇÃO}

Um dos grandes desafios a ser superado pela sociedade atual é o gerenciamento adequado de resíduos sólidos.

A quantidade de resíduos sólidos produzidos no mundo é elevada, sendo que, o desenvolvimento constante das nações, aumento da população e aumento do poder de consumo, tem levado a uma crescente geração de resíduos.

O gerenciamento adequado de resíduos sólidos, em seu sentido amplo, abrange a geração, estocagem local, coleta, transferência, transporte, processamento e recuperação, e disposição dos resíduos sólidos.

No Brasil, em localidades onde existe um gerenciamento efetivo dos resíduos sólidos, a disposição final destes resíduos é feita, em sua quase totalidade, em aterros sanitários.

Aterro sanitário pode ser definido como: "um processo utilizado para a disposição de resíduos sólidos no solo, particularmente lixo domiciliar, fundamentado em critérios de engenharia e normas operacionais específicas, permitindo um confinamento seguro em termos de controle ambiental e proteção a saúde publica" (IPT/CEMPRE, 2000).

Atualmente a disposição de resíduos industriais e municipais em aterros é o método mais difundido e econômico para a disposição de resíduos sólidos em países subdesenvolvidos ou em desenvolvimento, contudo, a tendência mundial principalmente em países desenvolvidos é que, os resíduos sólidos sejam tratados utilizando-se outros processos, como por exemplo, a incineração. Apesar de inúmeras restrições, o aterro sanitário tem sido utilizado como uma das alternativas para a disposição destes resíduos, de maneira a minimizar os efeitos negativos ao meio ambiente e a saúde pública

A escassez de áreas e a elevada quantidade de lixiviado gerada são os principais problemas da disposição de resíduos sólidos em aterros sanitários.

Os resíduos sólidos depositados em aterros decompõem-se através da combinação de processos químicos, físicos e biológicos. A decomposição produz subprodutos 
sólidos, líquidos e gasosos. Embora a decomposição física e química dos materiais presentes no lixo seja importante para a estabilização do aterro, a decomposição biológica desempenha o papel mais importante deste processo.

Devido ao alto poder poluente dos líquidos percolados, é necessário que seja feita a coleta, armazenamento e posterior tratamento desses líquidos. Dentre as tecnologias existentes para este fim destacam-se os tratamentos biológicos, a recirculação do lixiviado através do aterro e os tratamentos físico-químicos.

O lixiviado apresenta uma alta concentração de matéria orgânica refratária tornando o tratamento através de processos físico-químicos muito oneroso. O "stripping" com injeção de ar e filtração através de membranas têm sido os métodos físicos mais utilizados para o tratamento de lixiviado de aterro. Entre os métodos de tratamentos químicos para o tratamento de lixiviado, a coagulação-floculação, oxidação química ou eletroquímica são os mais utilizados, porém, para despejos brutos estas tecnologias não tem se mostrado muito eficientes.

Compostos orgânicos nitrogenados tais como amônia $\left(\mathrm{NH}_{3}\right)$ e íon amônio $\left(\mathrm{NH}_{4}^{+}\right)$, bem como vários compostos nitrogenados orgânicos, são usualmente encontrados no lixiviado. A contaminação de rios pelo lançamento de grandes quantidades de nitrogênio orgânico associadas a altas concentrações de fósforo podem provocar o processo de eutrofização

No lixiviado o nitrogênio na forma amoniacal pode alcançar concentrações muito elevadas, que podem inibir alguns processos biológicos de remoção de matéria orgânica, bem como causar toxicidade à vida aquática.

Com isso, a necessidade da remoção de compostos nitrogenados, presentes em altas concentrações em lixiviados, é de extrema necessidade, sendo que a utilização de processos de tratamento que visam uma melhora na eficiência de remoção destes compostos, bem como da matéria carbonácea presente no percolado, se faz cada vez mais necessário; Assim, o estudo da remoção do nitrogênio por via curta (via nitrito) juntamente com a remoção da matéria orgânica biodegradável, pode ser uma boa alternativa para a remoção biológica de nitrogênio presente no lixiviado de aterro, garantindo uma melhor qualidade do efluente final a ser lançado nos corpos d'água após o tratamento. 


\section{OBJETIVOS}

\subsection{OBJETIVO GERAL}

O objetivo global da presente pesquisa foi avaliar a remoção biológica do nitrogênio e de matéria orgânica, presente em líquido percolado de aterros sanitários, pela via curta (via nitrito), utilizando o próprio lixiviado como fonte de carbono para a etapa anóxica do processo (desnitritação), operando um sistema de lodos ativados em bateladas seqüenciais (SBR) em escala piloto.

\subsection{OBJETIVOS ESPECÍFICOS}

Os objetivos específicos da pesquisa foram:

- Avaliar a remoção de nitrogênio do lixiviado de aterro através do processo de "stripping" de amônia.

- Avaliar a utilização do percolado de aterro como fonte de carbono para os microrganismos responsáveis pela redução do nitrito na etapa anóxica do ciclo de tratamento.

- Obter as taxas de nitritação e desnitritação para o liquido percolado de aterro.

- Avaliar os requisitos operacionais para maximizar a nitritação. 


\section{REVISÃO BIBLIOGRÁFICA}

\subsection{PRINCIPÍOS GERAIS DE ATERRO SANITÁRIO}

Aterro sanitário pode ser definido como um método baseado em conceitos científicos, econômicos e de engenharia para se dispor resíduos sólidos, no solo, de maneira a se minimizar os riscos ambientais e à saúde pública (QASIM; CHIANG 1994; IPT/CEMPRE, 2000).

A operação de um aterro sanitário pode ser descrita, de maneira básica e simplista, como um conjunto de atividades que contempla o espalhamento dos resíduos sólidos em camadas sobre o solo, posterior compactação dos mesmos e por fim a cobertura, com terra, da camada compactada no final de cada dia de operação.

De acordo com ASSIS (1999), o uso de aterro sanitário como forma de disposição de resíduos sólidos, principalmente domésticos, teve início no Brasil na década de 1970, sendo que, na época, este método sofreu inúmeras críticas devido aos riscos que eles poderiam apresentar. Contudo, com o passar do tempo, o aterro sanitário passou a ser o método mais difundido método para a disposição de resíduos sólidos no Brasil.

Segundo MASSUKADO (2004), o aterro sanitário é considerado o melhor método para a disposição de resíduos sólidos, principalmente pela relativa simplicidade de operação e pelo baixo custo de operação e implantação.

Apesar de ser um dos métodos mais eficazes para a disposição de resíduos sólidos, os aterros sanitários podem causar inúmeros problemas ambientais, dentre eles estão, a lixiviação horizontal direta dos resíduos pelas águas subterrâneas, a lixiviação vertical dos resíduos pelas águas de percolação e a transferência de gases produzidos na decomposição dos resíduos para a atmosfera (ASSIS, 1999). É importante salientar que, tanto a lixiviação vertical como a horizontal dos resíduos sólidos do aterro, podem causar não só a contaminação dos recursos hídricos próximos ao local do aterro (lençol freático, nascentes, recarga de aqüífero), como também a contaminação do solo sobre o qual o aterro foi implementado, sendo que, a recuperação de solos contaminados por compostos provindos do lixiviado é onerosa. 
De acordo com QUASIM; CHIANG (1994), o controle e tratamento do lixiviado é o aspecto mais importante a ser considerado no desenvolvimento e operação de um aterro sanitário.

Devido aos inúmeros intervenientes, sejam ambientais, operacionais, econômicos, sociais e de saúde publica, a escolha da futura localização do aterro deve seguir critérios rigorosos e é uma das etapas mais difíceis do processo de implantação do mesmo. Dentre os principais fatores a serem analisados estão: características do resíduo que será disposto, tamanho da população atendida, modo da coleta e transporte dos resíduos, características hidrológicas, climatológicas e geológicas do local e custos de transporte (QUASIM; CHIANG, 1994; McBEAN; ROVERS; FARQUHAR, 1995; IPT/CEMPRE 2000).

A resolução CONAMA 001/86 deve ser consultada para realizar o Estudo de Impacto Ambiental (EIA) e Relatório de Impacto Ambiental (RIMA) quando se pretende desenvolver um projeto de aterros sanitários.

A concepção adotada para o tratamento do lixo aterrado é um importante parâmetro operacional a ser avaliado. De acordo com IPT/CEMPRE (2000), são três as formas de concepção para o tratamento do lixo:

1) Concepção anaeróbia tradicional: neste caso o resíduo é disposto em células com sistemas de proteção devidamente projetados. Estas células devem ser providas de um sistema completo de drenagem de gases e de líquidos percolados.

2) Concepção aeróbia: nesta condição os resíduos são decompostos com o auxílio da insuflação de ar dentro da massa de lixo, o que acarreta num maior custo de operação. A implantação de sistemas de coleta de gás e de percolado é indispensável para o bom funcionamento do processo.

3) Concepção biológica: este processo consiste na inoculação de microrganismos específicos da decomposição de matéria orgânica em células rigorosamente controladas; os microrganismos tem por função acelerar o processo de inertização do lixo.

Levando em conta os inúmeros problemas ambientais que podem surgir ao longo do período de operação de um aterro sanitário, devem-se adotar critérios construtivos 
rigorosos durante a construção do mesmo, tais como: sistema eficiente de impermeabilização do solo sobre o qual o aterro será implantado, rede completa de drenagem dos líquidos percolados e água pluvial e um sistema eficaz de coleta e tratamento dos gases gerados durante a decomposição do lixo.

Algumas vantagens pertinentes ao uso do aterro sanitário como forma de disposição de resíduos sólidos são: o controle da proliferação de vetores, possibilidade da disposição de lodos gerados no tratamento de água e esgotos domésticos e o baixo custo de operação. Já as desvantagens incluem: a locação de grandes áreas para a implantação do empreendimento, longo período necessário para a estabilização do aterro e o surgimento de grandes interferências na sua operação, causados principalmente por fatores meteorológicos (MASSUKADO, 2004).

\subsection{PrincíPIOS GERAIS dA DECOMPOSIÇÃo EM ATERROS SANITÁRIOS}

Os resíduos sólidos depositados em aterros decompõem-se através da combinação de processos químicos, físicos e biológicos. Tal decomposição produz subprodutos sólidos, líquidos e gasosos. Os processos biológicos agem na matéria orgânica presente no lixo antes mesmo de sua disposição no aterro. Contudo, a interdependência entre os três processos requer que tanto os processos físicos quanto os químicos sejam levados em consideração na decomposição biológica. Como exemplo, os processos físicos e químicos influenciam a disponibilidade de nutrientes essênciais para a ação biológica (QASIM; CHIANG, 1994; McBEAN; ROVERS; FURQUHAR, 1995).

Vários fatores interagem na decomposição do lixo em aterros, e um dos principais subprodutos dessa decomposição é o lixiviado, que pode variar tanto em qualidade como em quantidade (QUASIM; CHIANG, 1994).

A ação de bactérias anaeróbias (acetogênicas e metanogênicas), acelera o processo de decomposição do lixo, enquanto que a percolação da água de chuva carreia os subprodutos de degradação para as camadas inferiores do aterro(QUASIM; CHIANG, 1994). 
A decomposição física dos resíduos sólidos resulta na quebra ou movimento dos componentes do lixo devido principalmente à ação da descarga de água, sendo que estes movimentos são influenciados por fatores como gradiente de pressão e concentração do meio (McBEAN; ROVERS; FURQUHAR, 1995).

Os processos químicos tais como hidrólise, dissolução/precipitação, sorção/desorção e troca iônica, são importantes na decomposição do lixo. A decomposição química geralmente resulta na alteração das características e mobilidade dos componentes do lixo (McBEAN; ROVERS; FURQUHAR, 1995).

De acordo com QUASIM; CHIANG (1994), os processos biológicos ocorridos dentro do aterro são influenciados principalmente por fatores ambientais (temperatura, $\mathrm{pH}$ ), movimento de percolação da água, disponibilidade de macro e micronutrientes e a presença de compostos tóxicos ou inibitórios.

A decomposição da matéria orgânica em aterros sanitários, que é um dos processos originários do percolado, ocorre em três fases: 1) decomposição aeróbia; 2) decomposição anaeróbia (fase acetogênica); 3) decomposição anaeróbia (fase metanogênica) (QASIM; CHIANG, 1994; McBEAN; ROVERS; FURQUHAR, 1995).

\subsubsection{DECOMPOSIÇÃO AERÓBIA}

A fase aeróbia de decomposição do lixo é predominante inicialmente, ocorrendo geralmente nas primeiras camadas do aterro e com a presença de oxigênio. Esta fase é geralmente muito curta devido principalmente à limitação de oxigênio dissolvido e a alta Demanda Bioquímica de Oxigênio (DBO), proveniente da matéria orgânica constituinte do lixo. Nesta fase, os microrganismos aeróbios degradam a matéria orgânica, transformando-a em dióxido de carbono, água e resíduos orgânicos parcialmente degradados. Durante este processo é produzida uma grande quantidade de calor, fazendo com que a temperatura fique bem acima da ambiente, podendo atingir valores acima de $70^{\circ} \mathrm{C}$ (QUASIM; CHIANG, 1994; McBEAN; ROVERS; FURQUHAR, 1995).

Segundo QUASIM; CHIANG (1994), espera-se que o lixiviado produzido nesta fase contenha uma grande quantidade de sais solúveis, como por exemplo, o $\mathrm{NaCl}$. 


\subsubsection{FASE ACETOGÊNICA (ANAERÓBIA)}

Como conseqüência da queda na concentração de oxigênio dissolvido na fase de decomposição aeróbia, há o aparecimento de organismos facultativos anaeróbios, que dão continuidade ao processo de degradação da matéria orgânica. Nesta fase, conhecida também como acetogênica, uma grande quantidade de ácidos orgânicos voláteis são produzidos bem como dióxido de carbono, hidrogênio e amônia. A produção destes ácidos, juntamente com o hidrogênio, abaixam o pH do sistema para valores entre 4 e 5 . A queda no $\mathrm{pH}$ ajuda na solubilização de compostos inorgânicos, que, associados à alta concentração de ácidos voláteis, conferem ao lixiviado uma alta intensidade iônica.

QUASIM; CHIANG (1994) relatam que a DBO nesta fase é alta devida principalmente à grande concentração de ácidos voláteis e o potencial redox é reduzido a valores abaixo de zero.

\subsubsection{DECOMPOSIÇÃO ANAERÓBIA (METANOGÊNESE)}

Esta fase ocorre devido ao aumento da população de bactérias metanogênicas. As bactérias metanogênicas são estritamente anaeróbias e se desenvolvem melhor em meio neutro ( $\mathrm{pH}$ entre 6.6 e 7.3). Os ácidos voláteis produzidos na fase anterior e a matéria orgânica biodegradável resultante são convertidos pelas bactérias metanogênicas, em metano e dióxido de carbono. A queda na concentração de ácidos voláteis faz com que o pH do meio aumente (QUASIM; CHIANG, 1994; McBEAN; ROVERS; FURQUHAR, 1995).

QUASIM; CHIANG (1994), relatam que quando o pH do meio se aproxima de 7, a quantidade de compostos orgânicos solubilizados é pequena e há também uma queda na condutividade.

Os ácidos graxos voláteis servem como substrato para o crescimento as bactérias metanogênicas, contudo, altas concentrações podem inibir seu crescimento.

Com o passar dos anos, a taxa de decomposição das bactérias metanogênicas pode diminuir devido a diminuição de substrato. Tal fato pode provocar o restabelecimento 
de condições aeróbias já que o oxigênio continua a ser introduzido no meio trazido pela água de percolação do aterro (QUASIM; CHIANG, 1994).

Outros gases além do metano são produzidos durante a decomposição anaeróbia como, por exemplo, $\circ \mathrm{H}_{2} \mathrm{~S}$. $\mathrm{O}$ gás sulfídrico é produzido pelos microrganismos redutores de sulfato (McBEAN; ROVERS; FURQUHAR, 1995).

\subsection{CARACTERISTICAS GERAIS DA DISPOSIÇÃO DO LIXO NO BRASIL}

Os resíduos sólidos gerados nas atividades domésticas, sociais e industriais aumentaram significativamente em quantidade e variedade como conseqüência do crescimento populacional, do desenvolvimento tecnológico e das mudanças no padrão de consumo da sociedade brasileira. O problema da disposição inadequada de resíduos sólidos tem sido, ao longo do tempo, uma preocupação constante dos gestores municipais quando se discute a questão do saneamento básico (IBGE, 2002).

Apesar de não ser necessariamente do escopo deste trabalho vale salientar que a disposição inadequada de resíduos sólidos acarreta também em grandes problemas sociais como, por exemplo, a presença de catadores em lixões. De acordo com NUNESMAIA (2002), a presença de catadores é um indicativo do mercado de recicláveis, sendo que tais catadores se expõem a inúmeros riscos, dentre eles, a exposição a doenças e a acidentes.

Como a gestão de resíduos sólidos é caracterizada essencialmente pela prestação de serviços, não possuindo mecanismos que caracterizam a permanência física do sistema, o engajamento da administração municipal é essencialmente necessária, o que torna o sistema muito frágil, devido principalmente a mudanças na administração (IBGE, 2000).

Baseado em levantamentos feitos pelo Instituto Brasileiro de Geografia e Estatística (IBGE) nos anos de 2000, 2002 e 2005, pode-se concluir que a disposição final dos resíduos sólidos coletados no Brasil é feita, na sua maioria, em aterros sanitários, aterros controlados e lixões. Segundo a Pesquisa Nacional de Saneamento (PNSB) 
realizada pelo IBGE em $2000,47,1 \%$ do lixo coletado no país é disposto em aterros sanitários, 22,3\% em aterros controlados e 30,5\% em lixões, ou seja, mais de 69\% do lixo coletado no Brasil está sendo destinado em aterros sanitários/controlados. Porém em relação ao número de municípios estes resultados não são muito favoráveis já que, 63,6 \% utilizam lixões como forma de disposição final de resíduos sólidos e apenas $32,2 \%$ destinam o lixo gerado adequadamente $13,8 \%$ em aterros sanitários e $18,4 \%$ em aterros controlados), sendo que 5\% não informaram qual a destinação final de seus resíduos. O Quadro 1 demonstra a destinação final do lixo em relação ao número total de distritos que possuem coleta de resíduos, bem como a divisão de acordo com as grandes regiões brasileiras.

Quadro 1 - Distritos com serviços de limpeza e/ou coleta de lixo, por unidades de destinação final do lixo coletado, segundo as grandes regiões e unidade da federação.

\begin{tabular}{|l|c|c|c|c|c|c|c|c|c|}
\hline \multirow{2}{*}{$\begin{array}{c}\text { Unidade } \\
\text { da }\end{array}$} & \multicolumn{7}{|c|}{ Distritos com Limpeza e/ou coleta de lixo } \\
\cline { 2 - 11 } $\begin{array}{c}\text { Federação } \\
\text { e Grandes } \\
\text { Regiões }\end{array}$ & Total & $\begin{array}{c}\text { Vaza- } \\
\text { douro } \\
\text { a Céu } \\
\text { aberto } \\
\text { (lixão) }\end{array}$ & $\begin{array}{c}\text { Vaza- } \\
\text { douro } \\
\text { em } \\
\text { áreas } \\
\text { alagadas }\end{array}$ & $\begin{array}{c}\text { Aterro } \\
\text { contro- } \\
\text { lado }\end{array}$ & $\begin{array}{c}\text { Aterro } \\
\text { sani- } \\
\text { tário }\end{array}$ & $\begin{array}{c}\text { Aterro } \\
\text { de } \\
\text { resíduos } \\
\text { especiais }\end{array}$ & $\begin{array}{c}\text { Usinas } \\
\text { de } \\
\text { Compos- } \\
\text { tagem }\end{array}$ & $\begin{array}{c}\text { Usinas } \\
\text { de } \\
\text { reci- } \\
\text { clagem }\end{array}$ & $\begin{array}{c}\text { Incine- } \\
\text { ração }\end{array}$ \\
\hline \multicolumn{1}{|c|}{ Brasil } & 8381 & 5993 & 63 & 1868 & 1452 & 810 & 260 & 596 & 325 \\
\hline Norte & 512 & 488 & 8 & 44 & 32 & 10 & 1 & & 4 \\
\hline Nordeste & 2714 & 2538 & 7 & 169 & 134 & 69 & 19 & 28 & 7 \\
\hline $\begin{array}{l}\text { Centro- } \\
\text { Oeste }\end{array}$ & 563 & 406 & 1 & 132 & 125 & 29 & 6 & 19 & 3 \\
\hline Sudeste & 2846 & 1713 & 36 & 785 & 683 & 483 & 117 & 198 & 210 \\
\hline Sul & 1746 & 848 & 11 & 738 & 478 & 219 & 117 & 351 & 101 \\
\hline
\end{tabular}

Fonte: Adaptado da PNSB 2000.

Quando se trata da disposição de Resíduos Sólidos de Serviço de Saúde, a situação é ainda mais alarmante, pois apenas $9,5 \%$ dos municípios brasileiros encaminham este tipo de resíduos para aterros especiais (IBGE, 2000).

No que diz respeito à disposição final de resíduos sólidos industriais, dos 674 municípios que fazem este tipo de coleta, apenas $6,8 \%$ dos resíduos coletados são incinerados, 8,7 \% são dispostos em aterros industriais, 83\% em aterros domésticos e o restante (1,5\%), tem outras formas de disposição (IBGE, 2000). 
A pesquisa realizada pelo IBGE em 2002, apontando as causas da poluição hídrica do ar e do solo mostrou que, dos 5560 municípios pesquisados, 699 apontaram o lixiviado de aterro como fonte de contaminação do solo. Tal pesquisa mostrou ainda que 1949 municípios brasileiros adotaram a implantação de aterros sanitários como forma de controle da poluição e que somente 159 municípios brasileiros possuem aterro industrial para a disposição de resíduos tóxicos e perigosos.

Um estudo realizado pela Secretaria Nacional de Saneamento Ambiental e intitulado, “Diagnóstico do Manejo de Resíduos Sólidos Urbanos 2005”, demonstrou que, dos municípios brasileiros consultados, $26,7 \%$ dispõem seu resíduos sólidos em lixões, $33 \%$ em aterro controlado e 40,3\% em aterros sanitários. Vale salientar que no referido estudo, foram compilados dados de apenas 176 municípios brasileiros já que, segundo a Secretaria Nacional de Saneamento Ambiental, não há nenhuma obrigatoriedade legal e a participação dos municípios é voluntária; alguns deles não enviam os dados e outros os enviam incompletos ou com valores absurdos. Ainda segundo este levantamento, em relação à quantidade de resíduos coletados, 68,5 \% é disposto em aterros sanitários, 25,2\% em aterros controlados e 6,5\% em lixões, dados estes referentes somente aos 176 municípios participantes do estudo.

Levando em conta o panorama geral da disposição de resíduos sólidos no Brasil é de extrema importância a adoção de medidas que diminuam os impactos gerados em conseqüência da adoção dos sistemas utilizados para tais disposições; dentre estas medidas está o tratamento adequado do lixiviado gerado em aterros e a transformação dos lixões em aterros sanitários.

\subsection{GERAÇÃO E CARACTERÍSTICAS DO LIXIVIADO DE ATERRO SANITÁRIO}

O lixiviado de aterro sanitário pode ser definido como um líquido de cor escura, odor desagradável e alto poder poluidor, resultante da decomposição da matéria orgânica por meio de microrganismos existentes no sistema. A percolação das águas de chuva pela massa de resíduos arrasta consigo o lixiviado, bem como outros materiais em solução ou suspensão (PASCHOALATO, 2000). 
Uma das principais fontes da água presente em aterros é a precipitação. Parte dessa água é perdida através do escoamento superficial, outra parte é retornada para a atmosfera através da evapotranspiração superficial e o restante é armazenada no solo (camada usada na cobertura da célula de lixo). Quando a água armazenada excede a capacidade de saturação do solo, a umidade excedente percola através do solo. A água provinda da percolação do solo é transportada para a massa de lixo, fazendo com que a mesma também se sature. Assim como no solo a água excedente percola pela massa de lixo formando assim o lixiviado. A figura 1 mostra um esquema de formação do lixiviado em aterros.

\section{Precipitação}

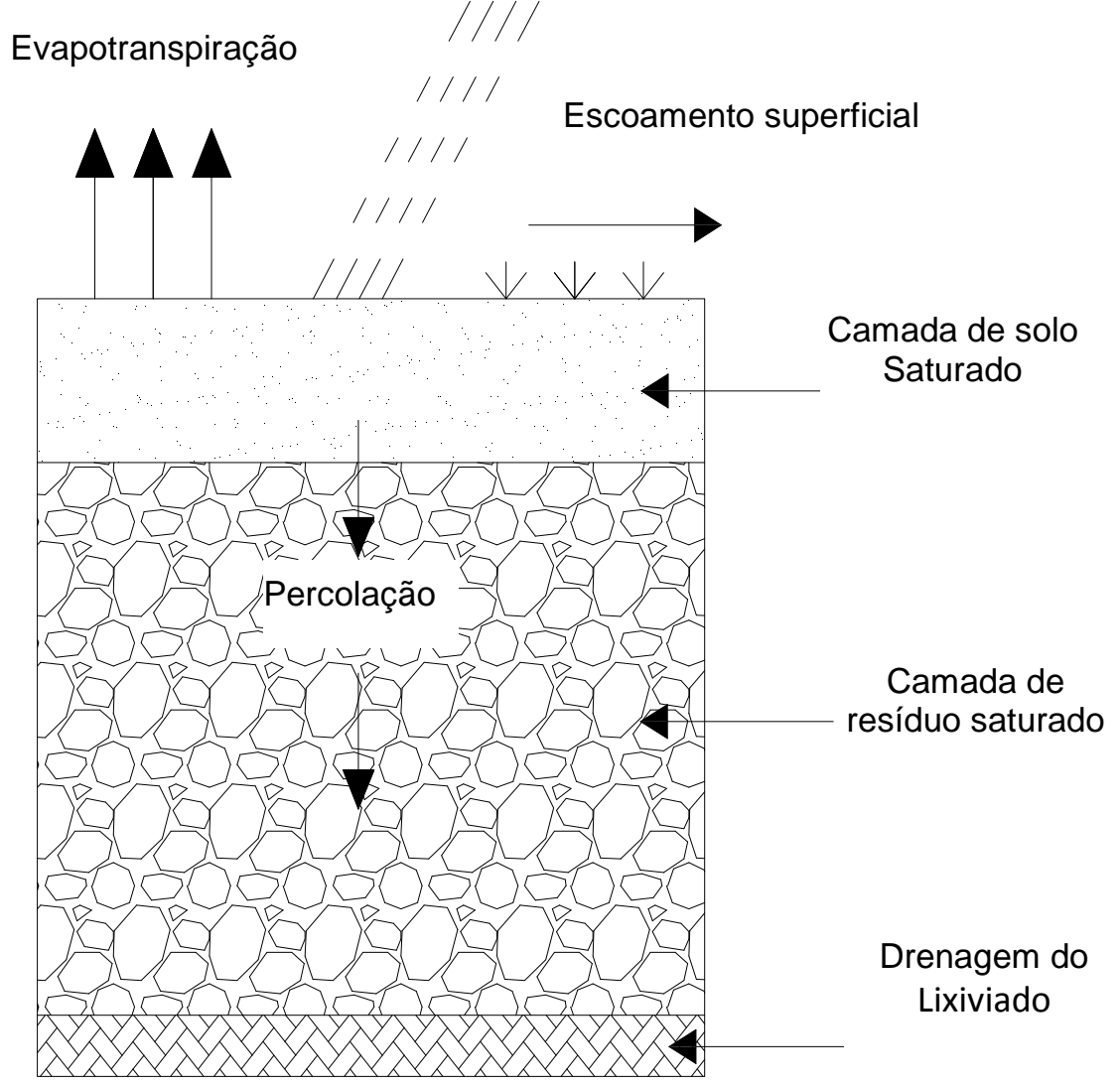

Figura 1 - Dinâmica do fluxo de água em um aterro sanitário. Fonte: adaptado de QUASIM; CHIANG, 1994.

Numerosas reações químicas e físicas ocorrem na água de infiltração que percola através da massa de lixo. Como resultado, inúmeros compostos orgânicos e inorgânicos são lixiviados para fora da massa de lixo. Os produtos dessa complexa combinação de reações são potencialmente transportados através da percolação do lixiviado. Durante os movimentos subseqüentes, processos físicos como por 
exemplo, a difusão, ocorrem em adição às reações químicas e biológicas (McBEAN; ROVERS; FURQUHAR, 1995).

Segundo McBEAN; ROVERS; FURQUHAR, (1995), o lixiviado contém muitos constituintes que podem ser encontrados tanto em esgoto doméstico como em efluentes industriais. Pode-se saber muito sobre o estado ou a idade do lixo no aterro monitorando-se a qualidade dos lixiviado. O processo básico de decomposição do lixo afeta as característica do gás produzido no aterro bem como a qualidade do percolado, sendo que esta informação é de extrema importância no desenvolvimento de sistemas de tratamento.

São inúmeros os fatores que podem alterar as características do percolado produzido no aterro. De acordo com QUASIM; CHIANG (1994); McBEAN; ROVERS; FURQUHAR (1995), os principais são:

- Composição do resíduo sólido;

- Forma de operação do aterro;

- Altura da camada de lixo;

- Fatores climáticos;

- Condições hidrogeológicas nas proximidades do local do aterro;

- Condições na massa de lixo, tais como atividades químicas e biológicas, presença de umidade, temperatura, pH e o grau de estabilização.

\subsubsection{FATORES QUE AFETAM A QUALIDADE DO LIXIVIADO}

Os esforços despendidos nos últimos anos para entender os processos que controlam a qualidade e a variabilidade do lixiviado têm sido focados principalmente em estudos lisimétricos, estes estudos identificam os componentes mais importantes do desenvolvimento e operação do aterro que afetam significativamente a composição do lixiviado. (McBEAN; ROVERS; FURQUHAR, 1995).

Além dos fatores citados no item 3.4, existem outros que podem influenciar na qualidade do lixiviado. O conhecimento destes fatores é de suma importância para a escolha do tipo de sistema adequado para o tratamento do mesmo. Dentre estes fatores estão: disposição do lixo juntamente com lodos resultantes de estações de 
tratamento de água (ETA) e tratamento de esgoto doméstico (ETE), disposição do lixo junto com resíduos perigosos e disposição do lixo com resíduos adsorventes.

Disposição do lixo com lodos de ETE: segundo QUASIM; CHIANG (1994), a disposição do lixo juntamente com lodos de ETE pode aumentar a umidade da massa de resíduo e como conseqüência, aumenta a geração de lixiviado. Os microrganismos e nutrientes presentes em grandes quantidades no lodo de ETE aumentam a taxa de estabilização biológica do aterro sanitário bem como provocam o aceleramento da atividade metanogênica do meio.

Disposição do lixo com lodos de ETA: Além do aumento da umidade da massa de resíduo, como dito anteriormente, a disposição do lodo de ETA no aterro pode provocar o aumento da presença de metais (produtos químicos contendo metais utilizados no tratamento de água) no lixiviado. Com exceção da maior acidificação do meio (aumento da atividade acetogênica), a presença destes metais não muda significativamente a qualidade química do lixiviado.

Disposição do lixo com resíduos perigosos: A disposição do lixo doméstico com resíduos perigosos pode ocasionar impactos dependedo de inúmeros fatores dentre eles, as propriedades físico-químicas dos despejos, mobilidade destes despejos no meio (aterro), as características globais estabelecidas durante a fase de estabilização biológica do lixo. Os aterros sanitários têm uma capacidade finita de processamento e atenuação dos constituintes orgânicos e inorgânicos presentes nos resíduos perigosos, assim quando esta capacidade é excedida os compostos não processados serão mobilizados para o lixiviado. A concentração de metais pesados pode ser atenuada por processos microbiológicos mediados por processos físicoquímicos, porém alguns desses metais são resistentes a estes processos o que pode provocar a inibição da fase metanogênica do processo de estabilização do aterro (QUASIM; CHIANG, 1994).

Disposição do lixo com resíduos adsorventes: A disposição de lixo juntamente com resíduos adsorventes como, por exemplo, cinzas de incinerador, calcário, pode reduzir a mobilidade de alguns constituintes perigosos do lixiviado. Isso deve-se a adsorção de íons metálicos e com menos freqüência à formação de compostos solúveis de cálcio e carbonato (QUASIM; CHIANG, 1994). 
De acordo McBEAN; ROVERS; FURQUHAR (1995), a temperatura da massa de lixo também influencia na qualidade do lixiviado já que, a mesma afeta o crescimento bacteriano. Elevadas temperaturas favorecem a maior solubilidade de sais bem como o aumento da velocidade cinética de reações químicas.

\subsubsection{Variações temporais no lixiviado}

Variações na qualidade do lixiviado com o tempo são esperadas já que, a composição do mesmo depende do processo de degradação biológica, e a matéria orgânica continua a sofrer estabilização com o tempo (QUASIM; CHIANG, 1994).

A maior concentração de poluentes no lixiviado se dá nos primeiros anos de vida do aterro (2 a 3 anos). Esta tendência se aplica também a outros constituintes como, por exemplo, DBO, DQO, COT e população microbiológica. Com o passar do tempo (3 a 5 anos), estes constituintes decrescem. Outros compostos têm sua concentração diminuída no lixiviado com o passar dos anos dentre eles estão: ferro, zinco, fosfato, sódio, cobre, nitrogênio orgânico, sólidos totais e sólidos em suspensão (QASIM; CHIANG, 1994; McBEAN; ROVERS; FURQUHAR, 1995).

Nos lixiviados provenientes de aterros não estabilizados, a maior parte dos compostos orgânicos é composto de ácidos graxos voláteis de cadeia curta (acético, propiônico e butírico). A segunda maior parte é devida, geralmente, a presença de ácidos fúlvicos e húmicos (compostos com peso molecular intermediário). Com o passar dos anos, a proporção destes componentes se altera. Há um decréscimo na concentração de ácidos graxos voláteis e um aumento na de ácidos fúlvicos e húmico. Outro composto que tem sua concentração aumentada no lixiviado com o passar do tempo, é o nitrogênio amoniacal (QASIM; CHIANG, 1994; McBEAN; ROVERS; FURQUHAR, 1995).

Devido ao fato do nitrogênio amoniacal ser um dos mais problemas significantes de poluição, a longo tempo, em aterros sanitários, é possível que sua presença determine quando o aterro é biologicamente estável e quando o monitoramento do mesmo poderá ser reduzido ou não ser necessário (BERGE; REINHART; BATARSEH, 2007). 


\subsection{TRATAMENTO DE LIQUIDOS PERCOLADOS DE ATERRO}

Diante do grande potencial poluidor do lixiviado de aterro caracterizado nos itens anteriores, é de extrema importância que se faça o tratamento do mesmo com o intuito de evitar os possíveis danos ambientais e à saúde pública.

Dentre as alternativas técnicas utilizadas para o tratamento do percolado de aterro sanitário estão o tratamento biológico (aeróbio e anaeróbio) e os tratamentos físicoquímicos.

A combinação do tratamento biológico e físico-químico pode ser também utilizada, sendo que muitas vezes a existência de um só tipo de tratamento não é suficiente para que se possa atingir a eficiência desejada. Em adição a estes tratamentos é possível que se faça a recirculação do lixiviado através do aterro, sendo este processo uma complementação dos tratamentos descritos anteriormente (QASIM; CHIANG, 1994; McBEAN; ROVERS; FURQUHAR, 1995).

O lixiviado pode ainda ser diluído em esgoto doméstico e posteriormente encaminhado para ser submetido ao mesmo tratamento dispensado a este.

Apesar das medidas adotadas em muitos países para se reduzir a quantidade de aterros sanitários (compostagem, incineração, reciclagem) e a modernização das técnicas de engenharia empregadas no desenvolvimento de aterros sanitários, a geração do lixiviado ainda é uma conseqüência inevitável da pratica de se dispor o lixo mesmo em aterros modernos (WISZNIOWSKI et al., 2006).

A seleção e o desenvolvimento do processo adequado para o tratamento do lixiviado não é nada simples. Fatores importantes devem ser levados em conta para a escolha do melhor tratamento a ser utilizado, o que inclui, características do lixiviado, custos, alternativas de descarga do lixiviado, alternativas tecnológicas e variações temporais da vazão e concentração dos compostos do lixiviado (QASIM; CHIANG, 1994; McBEAN; ROVERS; FURQUHAR, 1995).

\subsubsection{Tratamento Biológico}

Sem levar em conta o tipo de efluente, o processo de tratamento biológico consiste em controlar o ambiente requerido para o desenvolvimento ideal dos microrganismos 
envolvidos. Os microrganismos são responsáveis pela conversão da matéria carbonácea coloidal e dissolvida e elementos inorgânicos (Nitrogênio, Fósforo, Cálcio, etc.), em novos tecidos celulares, água e/ou inúmeros gases (metano, gás carbônico, etc.) (WISZNIOWSKI et al., 2006).

A utilização do substrato (material orgânico afluente) pelos microrganismos é conhecida como metabolismo. O material orgânico metabolizado é transformado quimicamente em produtos finais estáveis através de um processo que libera energia. A transformação bioquímica do material orgânico é conhecida como catabolismo. Outro processo que ocorre simultaneamente ao catabolismo, é o anabolismo que é a assimilação ou síntese de nova célula. A figura 2 representa esquematicamente o metabolismo de material orgânico (VAN HAANDEL; MARAIS, 1999).

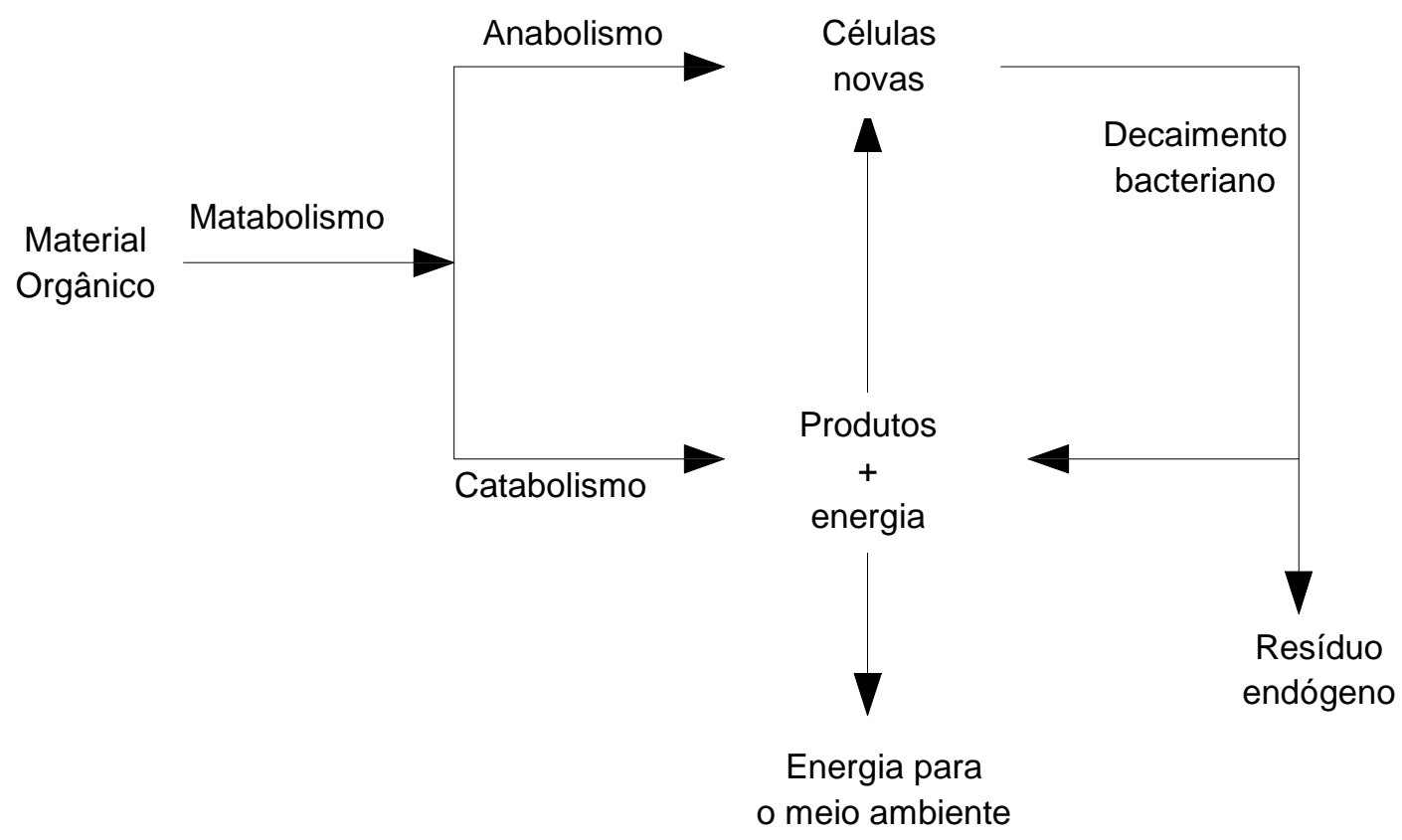

Figura 2 - Representação esquemática dos processos metabólicos da decomposição aeróbia. Fonte: adaptado de VAN HAANDEL; MARAIS, 1999.

De acordo com QASIM; CHIANG (1994), os processos envolvidos no tratamento biológico devem basear-se na otimização das condições ambientais no intuito de melhorar a degradação de matéria orgânica. Os métodos utilizados para aperfeiçoar a degradação biológica incluem: controle do nível de oxigênio dissolvido, adição de nutrientes, aumento na concentração de microrganismos e controle de alguns fatores ambientais $(\mathrm{pH}$, temperatura e grau de mistura). 
O objetivo do tratamento biológico do lixiviado é transformar os constituintes orgânicos em compostos estáveis, não putrescíveis, além de uma remoção eficiente de compostos nitrogenados.

Quando a relação DBO:DQO do lixiviado for alta $(>0,4)$, a melhor opção de tratamento, é o biológico, já que o mesmo é muito efetivo para a redução de materiais orgânicos biodegradáveis que podem ser caracterizados pela DBO. Além disso, o tratamento biológico pode contribuir para a redução de sólidos em suspensão e nitrogênio na forma amoniacal (McBEAN; ROVERS; FURQUHAR, 1995; QASIM; CHIANG, 1994).

A remoção de metais pesados presentes no lixiviado, pode dar-se pela precipitação como sulfeto ou carbonato, complexação com matéria orgânica ou adsorvidos no lodo.

De acordo com WISZNIOWSKI et al. (2006), os principais processos biológicos de tratamento (lodos ativados e filtros biológicos) são bem conhecidos e vem sendo aplicados eficientemente em esgotos domésticos. Contudo quando se trata de lixiviado, estes sistemas necessitam de algumas modificações, principalmente no que diz respeito aos parâmetros de controle operacional.

\subsubsection{Tratamento aeróbio}

Todos os processos aeróbios são baseados no mesmo princípio, ou seja, a decomposição da matéria orgânica por microrganismos na presença de oxigênio tendo como produtos finais dióxido de carbono e água. Os processos aeróbios se diferenciam pela maneira com que os microrganismos se apresentam no sistema, se em suspensão ou fixados em um meio suporte.

O conhecimento sobre o tipo de matéria orgânica presente no lixiviado é de suma importância para se determinar a quantidade de oxigênio necessária para a eficiência do processo de tratamento já que, o lixiviado, quando provindo de aterro "jovem", apresenta em sua composição uma grande quantidade de ácidos graxos voláteis, que são facilmente biodegradados em meio aeróbio, necessitando, relativamente, de uma grande quantidade de oxigênio para sua eficiente degradação, porém os percolados provindos de aterros "velhos" possuem uma 
grande proporção de matéria orgânica refratária necessitando assim, de uma melhor avaliação sobre a quantidade de oxigênio necessária para a estabilização destes compostos (McBEAN; ROVERS; FURQUHAR, 1995).

Além da decomposição de matéria orgânica, o tratamento aeróbio pode ser utilizado na remoção de nitrogênio, seja pela incorporação do mesmo pela biomassa dos microrganismos ou pelo processo de oxidação (oxidação do nitrogênio a nitrato) e posterior desnitrificação (redução do nitrato a nitrogênio gás).

Os processos de tratamento biológico aeróbio mais comuns para o tratamento de percolado são: lodos ativados (convencionais e em batelada), lagoas aeradas, filtros biológicos aeróbios e reatores biológicos de contato (biodiscos).

Lodo ativado convencional: O principio deste sistema é a remoção de material orgânico de águas residuárias, colocando-as em contato com lodo ativado (flocos constituídos de microrganismos e formados durante o processo de remoção do material orgânico), sendo que esta mistura de água residuária e lodo ativado é conhecida como licor misto. No licor misto, os flocos são mantidos em suspensão através da agitação provocada pelo sistema de aeração, que também tem a função de fornecer oxigênio para a oxidação do material orgânico. Depois de passar pelo tanque de aeração, o licor misto é encaminhado até o decantador, onde haverá uma separação da fase sólida e líquida, sendo que a fase sólida (lodo) é recirculada até o tanque de aeração e a fase liquida descartada (VAN HAANDEL; MARAIS, 1999). Um esquema básico do sistema de lodos ativados pode ser visto na figura 3. 


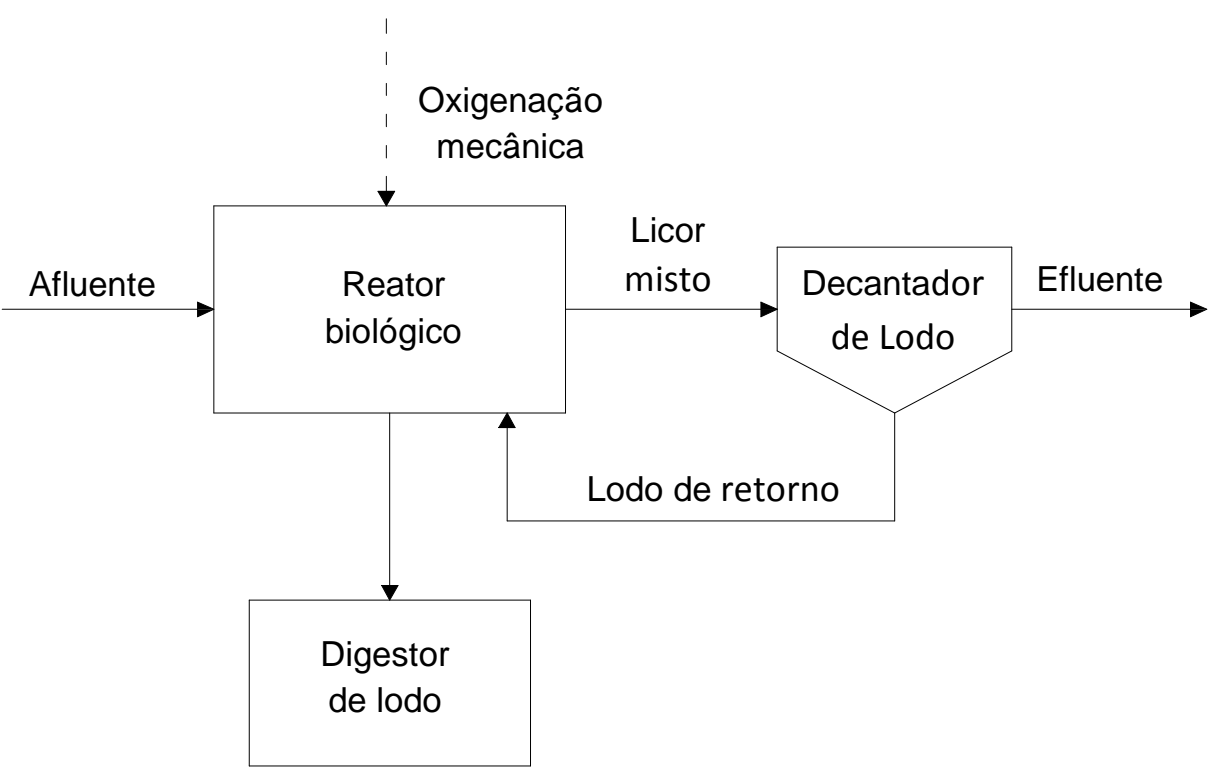

Figura 3 - Representação esquemática do funcionamento de um sistema de lodo ativado contínuo. Fonte: adaptado de VAM HAANDEL; MARAIS, 1999.

Com o intuito de se reduzir custos e aumentar a eficiência, o sistema de lodos ativados evoluiu ao longo do tempo fazendo com que surgissem algumas variantes do processo clássico, das quais as principais são: aeração decrescente, aeração escalonada, aeração modificada, aeração prolongada, lodos ativados em batelada e lodos ativados de estabilização por contato ("contact stabilization") (JORDÃO; PESSÔA, 2005).

O processo de lodo ativado e suas variantes vêm sendo largamente utilizado para o tratamento de lixiviado de aterro, demonstrando uma alta eficiência na remoção de matéria orgânica (DQO e DBO), bem como de compostos nitrogenados.

Devido à grande quantidade e variedade de compostos orgânicos presentes no lixiviado, os parâmetros operacionais do processo de lodo ativado, devem ser rigorosamente controlados, de maneira a propiciar uma extensiva atividade biológica para a estabilização desta matéria orgânica (QASIM; CHIANG, 1994).

Problemas como a inibição da atividade biológica pela presença de metais pesados, deficiência de nutrientes para os microrganismos e extensivo tempo de aeração para a estabilização da matéria orgânica presente no lixiviado, são pertinentes ao processo de lodo ativado tratando percolado de aterro (QASIM; CHIANG, 1994). 
Lodo ativado em bateladas seqüenciais: o primeiro sistema de lodos ativados em bateladas foi usado em 1914 por Ardem e Lockett, sendo que no sistema utilizado por eles, a água residuária era introduzida em um reator biológico que continha lodo ativado; depois de se encher o reator o mesmo era aerado, resultando na oxidação da matéria orgânica. Cessada a reação, a aeração era desligada e o lodo era separado da água residuária por sedimentação. Após o descarte da água tratada iniciava-se um novo ciclo de tratamento (VAN HAANDEL; MARAIS, 1999).

A partir da década de 1980 os reatores em batelada passaram a ser aplicados para o tratamento de uma variedade maior de efluentes. Isso se deve, em parte, ao maior conhecimento do processo, ao emprego de vertedores flutuantes mais confiáveis e ao desenvolvimento de instrumentos de controle mais eficientes (VON SPERLING, 2002).

A seqüência operacional de um reator em bateladas é, geralmente, composta das seguintes etapas: enchimento; reação; sedimentação; descarte do efluente tratado e repouso (VAN HAANDEL; MARAIS, 1999; JORDÃO; PESSÔA, 2005). A figura 4 mostra as diferentes etapas de operação de um reator de bateladas seqüenciais e a tabela 1 traz as informações pertinentes a cada fase do processo. 


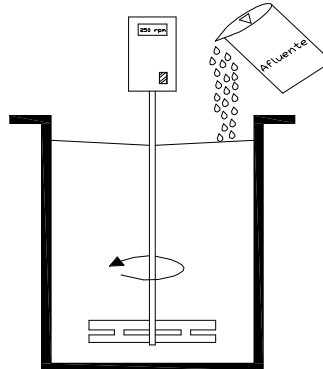

Enchimento com agitação

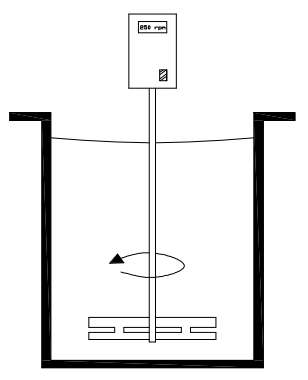

Reação com agitação

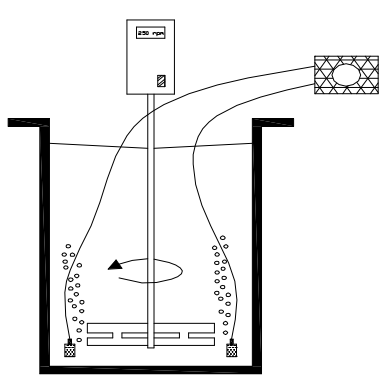

Enchimento com agitação $e$ aeracão

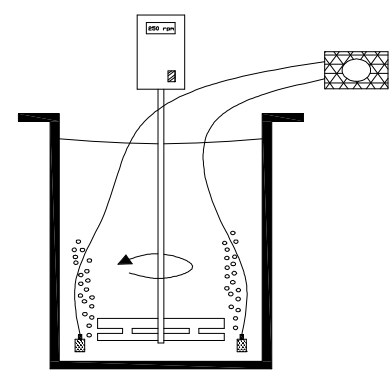

Reação com agitação e aeração

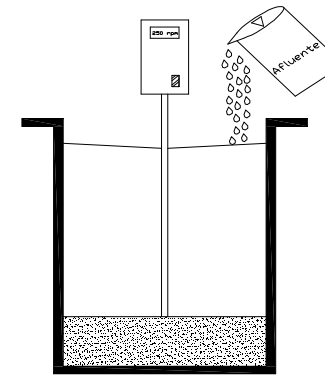

Enchimento em repouso

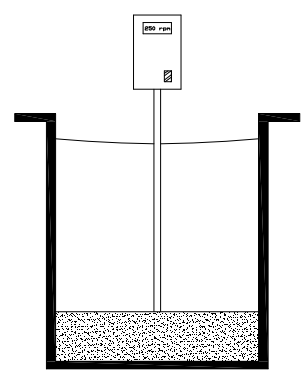

Sedimentação

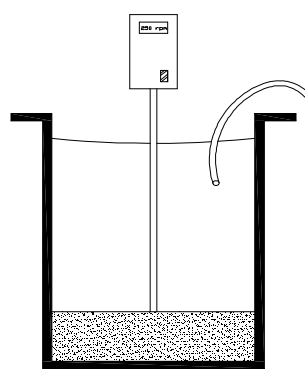

Descarte

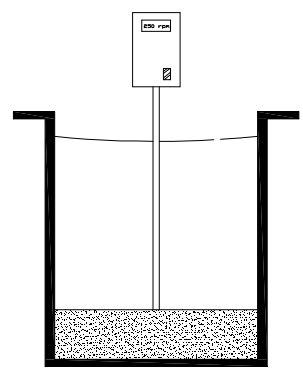

Repouso

Figura 4 - Etapas de operação de um sistema de lodos ativados em bateladas seqüenciais (Fonte: Adaptado JORDÃO; PESSÔA, 2005). 
Tabela 1 - Etapas do processo de lodos ativados em bateladas.

\begin{tabular}{|c|c|c|}
\hline $\begin{array}{l}\text { ETAPAS DO } \\
\text { CICLO }\end{array}$ & FINALIDADE & PARTICULARIDADE \\
\hline $\begin{array}{l}\text { Enchimento } \\
\text { com agitação }\end{array}$ & $\begin{array}{l}\rightarrow \text { Adição do Substrato } \\
\rightarrow \text { Ocorrência de reações anóxicas ou } \\
\text { anaeróbias }\end{array}$ & $\begin{array}{l}\rightarrow \text { O enchimento é feito com } \\
\text { mistura e sem aeração }\end{array}$ \\
\hline $\begin{array}{l}\text { Enchimento com } \\
\text { agitação e } \\
\text { aeração }\end{array}$ & $\begin{array}{l}\rightarrow \text { Adição do Substrato } \\
\rightarrow \text { Oxidação da matéria orgânica e N-NH}{ }_{4}^{+} \\
\rightarrow \text { Redução da duração do ciclo }\end{array}$ & $\begin{array}{l}\rightarrow \text { O enchimento é feito com } \\
\text { mistura e com aeração }\end{array}$ \\
\hline $\begin{array}{l}\text { Enchimento } \\
\text { em repouso }\end{array}$ & $\begin{array}{l}\rightarrow \text { Adição do Substrato } \\
\rightarrow \text { Ocorrência mínima de reações }\end{array}$ & $\begin{array}{l}\rightarrow \text { O enchimento é feito sem } \\
\text { mistura e sem aeração }\end{array}$ \\
\hline $\begin{array}{c}\text { Reação } \\
\text { com agitação }\end{array}$ & $\begin{array}{l}\rightarrow \text { Desnitrificação } \\
\rightarrow \text { Ocorrência de reações anóxicas ou } \\
\text { anaeróbias }\end{array}$ & $\begin{array}{l}\rightarrow \text { As reações ocorrem } \\
\text { com mistura e sem aeração }\end{array}$ \\
\hline $\begin{array}{l}\text { Reação com } \\
\text { agitação e } \\
\text { Aeração }\end{array}$ & $\begin{array}{l}\rightarrow \text { Oxidação de matéria orgânica } \\
\rightarrow \text { Ocorrência de reações aeróbias } \\
\rightarrow \text { Nitrificação }\end{array}$ & $\begin{array}{l}\rightarrow \text { As reações ocorrem com } \\
\text { mistura e com aeração }\end{array}$ \\
\hline Sedimentação & $\rightarrow$ Separação da fase sólida-liquida & $\begin{array}{l}\rightarrow \text { Ocorre sem mistura e sem } \\
\text { aeração }\end{array}$ \\
\hline Descarte & $\rightarrow$ Remoção do efluente tratado & $\begin{array}{l}\rightarrow \text { Ocorre sem mistura e sem } \\
\text { aeração }\end{array}$ \\
\hline Repouso & $\begin{array}{l}\rightarrow \text { Descarte do lodo em excesso } \\
\rightarrow \text { Ajustes operacionais para o início do } \\
\text { novo ciclo }\end{array}$ & $\begin{array}{l}\rightarrow \text { Ocorre sem mistura e sem } \\
\text { aeração }\end{array}$ \\
\hline
\end{tabular}

Fonte: VON SPERLING (2005).

Dentre as principais vantagens associadas ao tratamento de efluentes utilizando sistemas de bateladas seqüenciais estão: (VAN HAANDEL; MARAIS, 1999; JORDÃO; PESSÔA, 2005; VON SPERLING, 2002).

- O processo não necessita de bombas de recirculação de lodo;

- O tanque do sistema em batelada serve também como tanque de equalização o que propicia ao sistema uma maior resistência a cargas de choque e variações de vazão afluente;

- Simplicidade na operação do sistema;

- Boa sedimentabilidade do lodo produzido;

- O processo não necessita de um decantador final e não há equipamentos específicos para a sedimentação.

O processo de lodos ativados em bateladas seqüenciais (SBR) vem sendo usado largamente nos últimos anos para o tratamento de líquidos percolados de aterros 
sanitários, principalmente quando utilizado para a remoção de nitrogênio pelo processo de nitrificação/desnitrificação.

O tratamento apresenta também uma relativa eficiência na remoção de matéria orgânica, principalmente aquela provinda de aterros considerados "jovens" (não estabilizados), onde a fração de matéria orgânica recalcitrante é menor.

Em estudo realizado por KLIMIUK; KULIKOWSKA (2006), para avaliar a remoção de matéria orgânica de lixiviado de aterro, quatro reatores em bateladas seqüenciais foram operados com quatro tempos de detenção hidráulicos (TDH de 12h, 6h, 3h e 2h) e três formas de alimentação para cada TDH (alimentação em curto espaço de tempo; alimentação durante um longo período de tempo durante a mistura e sem aeração; alimentação por um longo período de tempo durante a aeração).

Os resultados desta pesquisa demonstraram uma eficiência de remoção da DBO (DBO afluente $=517 \mathrm{mg} / \mathrm{L}$ ) acima de $97 \%$ para as três formas de alimentação sendo que, houve um pequeno acréscimo na eficiência de remoção com o aumento do tempo de detenção hidráulico. Isto pode ser explicado pelo fato do aterro analisado não ser ainda estabilizado, tendo em sua composição uma alta concentração de matéria orgânica biodegradável, que é eficientemente removida até para um baixo TDH (KLIMIUK; KULIKOWSKA, 2006).

Já em termos de DQO (DQO afluente $=1348 \mathrm{mg} / \mathrm{L})$ a variação na eficiência de remoção foi mais significativa. Como na $\mathrm{DBO}$, houve um acréscimo na remoção de DQO com o aumento do tempo de detenção hidráulico, porém foram encontradas diferenças significativas na eficiência de remoção de DQO para as diferentes formas de alimentação para o mesmo TDH. A eficiência na remoção de DQO foi maior, para o mesmo TDH, quando a alimentação se deu em um longo período de tempo. $O$ curto tempo de alimentação, associado ao menor TDH, pode ter causado um desequilíbrio na assimilação do substrato, já que os microrganismos, nestas condições, primeiramente acumulam e armazenam o substrato para depois metabolizá-lo, o que poderia explicar a menor eficiência na remoção de DQO quando a alimentação se deu em um curto período de tempo e TDH de 2 dias (KLIMIUK; KULIKOWSKA, 2006). 
LAITINEN; LUONSI; VILEN (2006), encontraram eficiências de remoção acima de 94\% e de 99\% para DBO e nitrogênio amoniacal respectivamente, em um sistema de lodos ativados em bateladas tratando lixiviado de aterro, com TDH variando entre 4 e 8 dias. A concentração afluente de DBO deste estudo foi de, $1240 \mathrm{mg} / \mathrm{L}$ e a de nitrogênio amoniacal de $210 \mathrm{mg} / \mathrm{L}$.

O reator SBR convencional (lodo em suspensão) pode apresentar algumas variações, como por exemplo, ser operado como um biofilme preenchido com um meio suporte para o crescimento dos microrganismos. Este tipo de reator foi operado por TENGRUI et al. (2007) para avaliar a remoção de nitrogênio amoniacal de um lixiviado de aterro sanitário constituído de uma grande parcela de matéria orgânica biorefratária (aterro "velho"). Os resultados demonstraram uma eficiência na remoção de $\mathrm{N}^{-\mathrm{NH}_{4}}{ }^{+}$acima de $99 \%$ para um tempo de detenção de 9 horas. A concentração inicial de $\mathrm{N}-\mathrm{NH} 4^{+}$era de $1100 \mathrm{mg} / \mathrm{L}$. A taxa de conversão de nitrogênio encontrada foi de $0,51 \mathrm{Kg} \mathrm{NT} / \mathrm{m}^{3}$.d, para uma temperatura variando entre $30-33^{0} \mathrm{C}$ e $\mathrm{pH}$ entre 7,4 e 8,6 .

Devido a presença de grandes concentrações de compostos nitrogenados e matéria orgânica, muitas vezes recalcitrante, em lixiviados de aterros, os pesquisadores tem cada vez mais buscado alternativas de tratamento que melhorem a eficiência de remoção destes compostos, sendo que a associação do tratamento biológico com o tratamento físico-químico é uma dessas alternativas.

Em trabalho realizado por UYGUR; KARGI (2004), no intuito de avaliar a remoção de nutrientes (nitrogênio e fósforo) e matéria orgânica, um reator SBR foi utilizado no tratamento de lixiviado de aterro previamente tratado por um processo físicoquímico. Neste trabalho foi também avaliada a eficiência na remoção destes constituintes em outras duas condições: 1) diluição do lixiviado com esgoto doméstico no volume 1/1 (v/v), mais a adição de carvão ativado granulado (PAC); 2) diluição do lixiviado com esgoto doméstico no volume $1 / 1(\mathrm{v} / \mathrm{v})$, sem a adição de PAC. O tratamento físico-químico utilizado foi coagulação-floculação (dosagem de $1 \mathrm{~g} \mathrm{CaO} / \mathrm{L}$ em $\mathrm{pH}=12$ ) seguido de "stripping" de amônia sendo que, o intuito deste pré-tratamento foi estabelecer uma relação entre DQO/N/P de 100/6/2. Os resultados demonstram um aumento na eficiência de remoção de matéria orgânica e fósforo, quando se diluiu o lixiviado com esgoto doméstico. Já as maiores eficiências 
de remoção (DQO, fósforo, $\mathrm{N}-\mathrm{NH}_{4}^{+}$) foram obtidas quando foi adicionado ao reator o

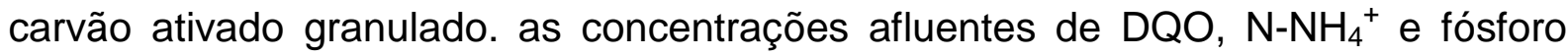
eram de 1.400, 107 e 65 mg/L respectivamente). As eficiências de remoção foram as seguintes:

- Lixiviado pré-tratado: 62\% para DQO, 31\% para $\mathrm{N}_{-} \mathrm{NH}_{4}{ }^{+}$e $19 \%$ para fósforo.

- Lixiviado pré-tratado diluído com esgoto 1/1 (v/v): 64\% para DQO, 23\% para $\mathrm{N}-\mathrm{NH}_{4}^{+}$e $26 \%$ para fósforo.

- Lixiviado pré-tratado diluído com esgoto $1 / 1$ (v/v) e com adição de CAP (dosagem 1g/L): $75 \%$ para DQO, 44\% para $\mathrm{N}^{-\mathrm{NH}_{4}}{ }^{+}$e $44 \%$ para fósforo.

O reator de lodo ativado em bateladas seqüenciais é um dos mais eficientes sistemas que podem ser utilizados na remoção de nitrogênio, seja pelo processo convencional de nitrificação/desnitrificação ou por outras variações do sistema; isso se dá, em parte, pela facilidade de controle operacional do processo. As remoções de matéria orgânica nestes sistemas são significantes, porém, como o lixiviado traz em sua composição uma grande quantidade de compostos não biodegradáveis, a associação do sistema SBR com um sistema físico-químico, para a remoção destes constituintes, se mostra como uma boa alternativa.

Lagoas aeradas: As lagoas aeradas constituem uma modalidade do processo de tratamento por lagoas de estabilização, onde o suprimento de oxigênio é efetuado por dispositivos eletromecânicos, com a finalidade de manter uma concentração de oxigênio dissolvido em toda ou parte da massa liquida (JORDÃO; PÊSSOA, 2005).

McBEAN; ROVERS; FURQUHAR (1995) relatam que as lagoas aeradas têm grande capacidade de estabilização de efluentes com presença de matéria orgânica refratária de alto peso molecular dependendo é claro, do tempo de detenção. Este é o caso, por exemplo, de lixiviado proveniente de aterros estabilizados.

Devido ao fato das lagoas aeradas, geralmente, não proporcionarem uma boa mistura da massa líquida, uma porção dos sólidos pode depositar-se no fundo do sistema o que pode causar o desenvolvimento de processos de decomposição anaeróbia nesta região, transformando o sistema em uma lagoa aerada facultativa (QASIM; CHIANG, 1994; VON SPERLING, 1996). 
Em pesquisa realizada por MOSER (2003), para estudar a remoção de nitrogênio e matéria orgânica de lixiviado de aterro sanitário utilizando sistemas de lagoas aeradas, três condições operacionais foram investigadas. A primeira condição foi a utilização de uma lagoa aerada com tempo de detenção celular de 50 dias e temperatura média de $25{ }^{\circ} \mathrm{C}$ (Lag 50,25); para a segunda condição a lagoa foi operada com tempo de detenção celular de 40 dias e temperatura de $25{ }^{\circ} \mathrm{C}$ (Lag 40,25); e na terceira condição a lagoa foi operada com 80 dias de detenção celular e temperatura de $20^{\circ} \mathrm{C}$ (Lag 80,20$)$. As eficiências médias na remoção de DQO para as condições Lag 50,25; Lag 40,25 e Lag 80,20 foram de 49\%, 31,6\% e 61,6\% respectivamente. Já as eficiências médias na remoção de nitrogênio amoniacal para as condições Lag 50,25; Lag 40,25 e Lag 80,20 foram de 96,5\%, 94\% e 88,3\% respectivamente. A maior eficiência média na remoção de DBO (99,6\%), foi obtida na condição Lag 80,20. Como era de se esperar, as maiores eficiências na remoção de matéria orgânica estão associadas aos maiores tempos de detenção. No que se refere à remoção de nitrogênio amoniacal, a maior eficiência foi condicionada a maior temperatura (LAG 50,25), ratificando assim a influencia da temperatura no processo de nitrificação.

A escolha do uso de lagoas aeradas para o tratamento de lixiviado deve levar em conta fatores como: concentração de matéria orgânica biodegradável no efluente, já que este sistema é mais indicado para o tratamento de efluentes com altas concentrações de compostos biodegradáveis; disponibilidade de área e energia elétrica; necessidade de um pós-tratamento, já que a concentração de sólidos em suspensão no afluente é alta.

Filtros biológicos percoladores: O mecanismo de funcionamento dos filtros biológicos percoladores consiste na alimentação e percolação contínua do afluente através de um meio suporte. A contínua passagem do efluente pelos interstícios do sistema promove o crescimento de microrganismos aderidos ao meio suporte, sendo os mesmos responsáveis pela degradação da matéria orgânica que percola continuamente através do filtro. A condição aeróbia do sistema é garantida pela passagem de oxigênio através dos espaços vazios constituintes do meio suporte. Quando as condições do filtro são favoráveis ao crescimento de microrganismos, mais matéria orgânica é decomposta, provocando assim a síntese de novas células. O crescimento excessivo da biomassa prejudica a passagem de oxigênio para as 
camadas internas da biomassa sendo que nestas camadas, o processo de oxidação se dá anaerobiamente (JORDÃO; PESSÔA, 2005).

De acordo com carga orgânica volumétrica aplicada, os filtros biológicos podem ser classificados como: filtros de baixa taxa; filtros de taxa intermediária; filtros de alta taxa (JORDÃO; PESSÔA, 2005).

Devido ao curto tempo de contato do efluente com os microrganismos aderidos ao meio suporte, a remoção de compostos orgânicos não é alta. Por isso, a recirculação do efluente do filtro se faz necessária. O processo pode ser usado como póstratamento de outro sistema biológico, já que o mesmo não é eficiente quando utilizado como única alternativa de tratamento (QASIM; CHIANG, 1994).

O processo de nitrificação não é normalmente obtido em filtros biológicos, com exceção daqueles com taxas de aplicação muito baixas (carga orgânica volumétrica e carga hidráulica), ou então os filtros de dois estágios, ambos podendo produzir efluentes bem nitrificados (QASIM; CHIANG, 1994; JORDÃO; PESSÔA, 2005).

Os filtros biológicos consomem baixa quantidade de energia quando comparados a outros sistemas de tratamento como, por exemplo, lodos ativados. Contudo, há algumas limitações na sua capacidade de tratamento de lixiviado de aterro com altas concentrações de compostos orgânicos. Dentre elas estão, o não suprimento do oxigênio necessário para manter o sistema aeróbio e/ou o crescimento excessivo de biomassa provocando, rapidamente, a comatação do filtro (McBEAN; ROVERS; FURQUHAR, 1995).

KNOX (1985) estudou, durante dois anos, o processo de nitrificação em um filtro biológico preenchido por anéis randômicos de plástico corrugado. O lixiviado estudado era proveniente de um aterro estabilizado, que possuía uma baixa concentração de matéria orgânica biodegradável. Os estudos indicaram que a amônia presente no lixiviado foi completamente nitrificada sendo que, a taxa máxima de nitrificação encontrada, ficou em torno de $309 \mathrm{mg} \mathrm{N}-\mathrm{NH}_{3} \cdot \mathrm{m}^{-2} \cdot \mathrm{d}^{-1}$ para uma temperatura de $16^{\circ} \mathrm{C}$. Durante o período da pesquisa não houve inibição no processo de nitrificação. Esta pesquisa revelou, devido ao seu longo tempo de duração, as flutuações na concentração durante o período de estudo, tanto de nitrogênio amoniacal quanto de matéria orgânica. Este fato se coloca como uma 
dificuldade de se utilizar filtros percoladores para o tratamento de lixiviado em escala real.

Processos com material suporte em suspensão: Este tipo de tratamento, conhecido também como "moving bed biofilm reactor-MBBR", consiste na introdução de um material suporte nos tanques de aeração dos processos de lodos ativados (contínuos ou em batelada), ao qual são aderidas colônias de microrganismos. O material de enchimento pode ocupar de 25 a 75\% do volume do tanque de aeração, mantendo-se em suspensão pela própria agitação provocada pelo sistema de aeração (fase aerada), ou então por hélices de agitação, no caso de reatores anóxicos. O crescimento do biofilme aderido ao meio suporte aumenta a concentração de biomassa no tanque de aeração, reduzindo o volume requerido para o mesmo (JORDÃO; PESSÔA, 2005).

O processo MBBR tem sido muito utilizado no processo de nitrificação e desnitrificação de efluentes com altas concentrações de nitrogênio, como por exemplo, o lixiviado de aterro. O processo de nitrificação, em sistemas MBBR, tem demonstrado ser bastante dependente da concentração de oxigênio dissolvido no reator (HEM et al., 1994).

WELANDER; HENRYSSOW; WELANDER, (1997) investigaram a influência do tempo de detenção hidráulico e da temperatura na nitrificação de lixiviado de aterro sanitário, utilizando um sistema MBBR. O uso de diferentes meios suportes foi também avaliado bem como a remoção de matéria orgânica. Os resultados deste trabalho demonstraram que o sistema MBBR se mostrou como uma boa alternativa para a nitrificação de lixiviado de aterro sanitário, já que as taxas de nitrificação foram as mesmas encontradas, em pesquisas anteriores, em sistemas de lodos ativados sendo que, as maiores taxas de nitrificação encontradas são referentes as temperaturas mais altas. Os pesquisadores concluíram também, que os sistemas MBBR tem algumas vantagens em relação ao sistema com biomassa em suspensão como, por exemplo, o pequeno risco de perda de biomassa devido a problemas de separação, simplicidade de operação e baixa influência da temperatura nas taxas de nitrificação, pois como demonstrado no estudo, mesmo para baixas temperaturas (5 ${ }^{0} \mathrm{C}$ ), a eficiência da nitrificação foi acima de $75 \%$. A eficiência na remoção de DQO (DQO afluente $=800-1300 \mathrm{mg} / \mathrm{L})$ foi baixa $(25-30 \%)$. Este resultado já era esperado, 
pois o lixiviado analisado era previamente tratado em uma lagoa aerada com alto TDH (14 d).

Há grandes possibilidades para o aprimoramento dos sistemas MBBR, a serem utilizados como alternativa de tratamento para líquidos percolados de aterros sanitários como, por exemplo, o desenvolvimento de novos meios suporte que propiciem maiores eficiências para este tipo de despejo.

Reatores biológicos de contato (RBC): Os reatores biológicos de contato (conhecidos também como biodiscos) consistem em uma série de placas circulares de plástico (discos) montados sobre um eixo que gira lentamente. Estes discos ficam parcialmente imersos ( $40 \%$ do disco) em um tanque através do qual escoa o efluente em tratamento. Os discos são espaçados de forma a permitir que o ar passe pela superfície exposta. Os microrganismos crescem aderidos aos discos, e são expostos alternadamente ao ar e ao efluente. A biomassa chega a cobrir completamente o disco, até o ponto que pelo próprio peso se desprendem para serem removidos por sedimentação no decantador secundário (QASIM; CHIANG, 1994; JORDÃO; PESSÔA, 2005).

SPENGEL; DZOMBAK (1991) realizaram um estudo com o intuito de avaliar o processo de nitrificação e a remoção de matéria orgânica em um reator biológico de contato, tratando lixiviado de aterro sanitário. Os resultados deste trabalho mostraram que houve uma completa nitrificação do lixiviado, quando o sistema foi submetido a uma carga hidráulica variando entre $5-15 \mathrm{~m}^{3} \cdot \mathrm{m}^{-2} \cdot \mathrm{d}^{-1}$. Contudo a eficiência na remoção de matéria orgânica (DQO) foi de no máximo 38\%. A baixa relação DBO/DQO (menor que 0,1 ) pode explicar esta pequena remoção de matéria orgânica.

CASTILLO; VERGARA; MORENO, (2007) investigaram o uso de RBC para o tratamento de lixiviado de aterro sanitário pré-tratado. Na primeira fase da pesquisa, o reator foi operado com diferentes tipos de material suporte, taxas variáveis de carga orgânica aplicada (taxas entre 9,2 e 17 g-DQO.m-2.dia-1) e velocidade de rotação de 4 rpm. Os resultados desta fase demonstraram que a maior eficiência na remoção de DQO (75\%) foi obtida, quando se utilizou como material suporte, discos de acetato perfurados e taxa de aplicação igual a 17 g-DQO.m-2.dia-1. Para a segunda fase da pesquisa, o material suporte de acetato perfurado foi utilizado para 
investigar a remoção de DQO no sistema quando sujeito a diferentes tempos de detenção hidráulico $(54,44,39,24$ e 17h) bem como diferentes velocidades de rotação (3, 6 e 9 rpm). Os resultados desta fase demonstraram que, como era de se esperar, a maior remoção de DQO foi relativa ao maior tempo de detenção hidráulico e a menor velocidade de rotação, isso para uma concentração de DQO do lixiviado variando entre 2500 e $9000 \mathrm{mg} . \mathrm{DQO} / \mathrm{L}$. Durante todo o período do experimento, a concentração de oxigênio dissolvido no meio ficou abaixo de $0.4 \mathrm{mg}-\mathrm{O}_{2} / \mathrm{L}$, isso devido a alta carga orgânica aplicada no sistema. Contudo, a baixa concentração de oxigênio dissolvido não foi limitante para o crescimento do biofilme, já que a maior parte deste oxigênio foi obtido através do contato do biofilme com o ar.

\subsubsection{Tratamento anaeróbio}

O Tratamento anaeróbio de esgoto é um processo complexo que envolve vários tipos de bactérias trabalhando conjuntamente, dentre elas as bactérias facultativas e anaeróbias.

O principio do tratamento anaeróbio baseia-se na conversão de compostos orgânicos em metano e dióxido de carbono em um ambiente livre de oxigênio. Conceitualmente a digestão anaeróbia pode ser descrita como um processo de três estágios que envolvem: 1) hidrólise, liquefação e fermentação; 2) formação de hidrogênio e acido acético (acetogênese); 3) formação de metano (metanogênese) (PARKIN; OWEN, 1986).

Para que o tratamento anaeróbio seja eficiente, existem algumas condições que devem ser atendidas no intuito de propiciar o melhor desenvolvimento das bactérias que governam o processo bem como aperfeiçoar a operação do mesmo. Dentre estes fatores estão: tempo retenção de hidráulica ótimo ; mistura adequada (contato substrato-bactéria); $\mathrm{pH}$ apropriado; controle de temperatura adequado; concentração de nutrientes adequada; ausência ou controle de materiais tóxicos (PARKIN; OWEN, 1986).

No inicio o tratamento anaeróbio era utilizado somente para a estabilização de lodos provenientes de tratamentos de efluentes, porém, com a evolução da digestão anaeróbia, o mesmo passou a ser utilizado como alternativa para o tratamento de 
efluentes, principalmente domésticos (VAN HAANDEL; MARAIS, 1999; JORDÃO; PESSÔA, 2005).

Segundo VAN HANDEL; MARAIS (1999), as principais vantagens da utilização dos sistemas anaeróbios para o tratamento de efluentes são:

- Remoção de material orgânico a uma alta taxa volumétrica;

- Baixa produção de lodo;

- Lodo produzido já é estabilizado.

Os processos anaeróbios têm sido também utilizados no tratamento de lixiviado de aterro sanitário, porém, este tipo de tratamento é moderadamente eficiente na remoção da matéria orgânica presente no lixiviado (QASIM; CHIANG, 1994).

Outras vantagens atribuídas à utilização do processo anaeróbio para o tratamento de lixiviado são: o gás metano gerado durante o processo pode ser utilizado na geração de energia para o suprimento de outros processos de tratamento; o sistema não necessita de equipamentos de aeração, o que representa uma diminuição no consumo de energia. Em contrapartida, o processo apresenta algumas desvantagens como por exemplo, a necessidade de altas temperaturas para atingir um eficiente tratamento; relativo longo tempo de detenção; remoção incompleta de orgânicos e redução limitada de N-NH 3 (McBEAN; ROVERS; FURQUHAR, 1995).

A utilização de um tratamento complementar ao anaeróbio é uma boa alternativa para suprir as desvantagens pertinentes a este processo. Porém, devido às características do efluente provindo da digestão anaeróbia, a utilização de alguns sistemas de pós-tratamento pode ser prejudicada.

Os principais sistemas de tratamento anaeróbio utilizados no tratamento de líquido percolado de aterro sanitário são o reator UASB (Upflow Anaerobic Sludge Blanket) e os filtros anaeróbios.

Reatores UASB: este sistema é conhecido também como reator de manta de lodo; nele o lodo encontra-se em suspensão, agregado na forma de floco. As bactérias formam flocos ou grânulos que podem possuir boa sedimentabilidade. Esta massa de bactérias forma uma manta de lodo no interior do reator (JORDÃO; PESSÔA, 2005). 
De acordo com JORDÃO; PESSÔA (2005), as principais partes constituintes de um reator UASB são: 1) câmara de digestão; 2) separador de fases; 3) zona de transição; 4) zona de sedimentação; 5) zona de acumulação de gás. Um esquema do reator UASB pode ser visto na figura 5 .

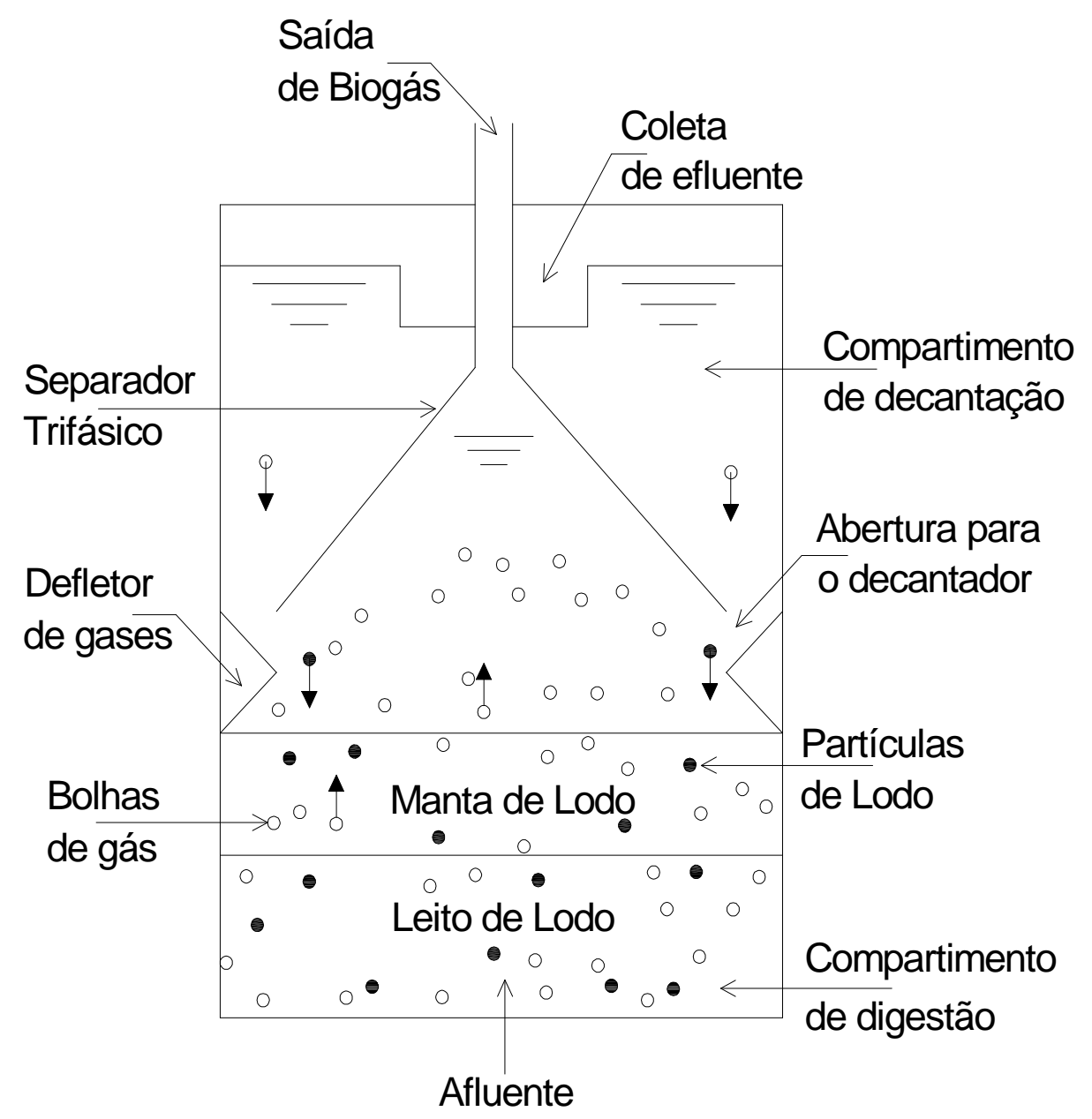

Figura 5 - Representação esquemática de um reator UASB. Fonte: Adaptado de JORDÃO; PESSÔA (2005).

O reator UASB é o sistema de tratamento anaeróbio mais utilizado no tratamento de efluentes a taxa elevada. A água residuária entra no fundo do reator e segue uma trajetória ascendente, passando pelo compartimento de digestão, atravessando a abertura existente no separador de fases e entrando no compartimento de decantação. $O$ efluente que entra no reator é digerido anaerobiamente ao passar pela manta de lodo, o que resulta na produção de gás e no crescimento de lodo (VAN HAANDEL; MARAIS, 1999). 
Devido a remoção ineficiente de nitrogênio amoniacal em sistemas anaeróbios, a associação destes com outros sistemas que promovam uma remoção eficiente de nitrogênio amoniacal, se faz necessário.

IM et al. (2001) estudou a remoção de matéria orgânica e nitrogênio de lixiviado em um sistema anaeróbio-aeróbio. Neste trabalho o reator anaeróbio foi utilizado tanto para a redução de matéria orgânica como para o processo de desnitrificação; para isso o efluente provindo do tratamento aeróbio era recirculado para o reator anaeróbio. Neste caso a concentração de DQO e de $\mathrm{N}-\mathrm{NH}_{4}{ }^{+}$afluente era de 24.400 $\mathrm{mg} / \mathrm{L}$ e $1.682 \mathrm{mg} / \mathrm{L}$ respectivamente. A máxima taxa de remoção de DQO no reator anaeróbio foi de $15,2 \mathrm{Kg} \mathrm{DQO} \cdot \mathrm{m}^{-3}$, já no reator aerado, a taxa máxima de remoção de $\mathrm{N}-\mathrm{NH}_{4}{ }^{+}$e a taxa máxima de nitrificação foram de $0.84 \mathrm{~N}-\mathrm{NH}_{4}{ }^{+} \cdot \mathrm{m}^{-3} \cdot \mathrm{d}^{-1}$ e $0,50 \mathrm{~kg} \mathrm{~N}-$ $\mathrm{NO}_{3}{ }^{-} \cdot \mathrm{m}^{-3} \cdot \mathrm{d}^{-1}$ respectivamente. A eficiência da desnitrificação no reator anaeróbio foi de $100 \%$ para todas as faixas de carga volumétrica de $\mathrm{N}-\mathrm{NH}_{4}{ }^{+}$aplicadas, sendo que somente $10-20 \%$ da matéria orgânica removida no reator anaeróbio foi devido à desnitrificação e o restante $80-90 \%$ devido à metanogênese. Outra observação importante desta pesquisa é que, tanto a eficiência na remoção de $\mathrm{N}_{-} \mathrm{NH}_{4}{ }^{+}$como a taxa de nitrificação decresceu com o aumento da carga volumétrica de $\mathrm{N}-\mathrm{NH}_{4}{ }^{+}$ aplicada.

AGDAG; SPONZA (2005) operaram um sistema anaeróbio-aeróbio para a remoção de matéria orgânica e nitrogênio de lixiviado de aterro. O sistema era composto por dois reatores UASB em série seguido de um reator aerado. As eficiências na remoção de DQO no primeiro e no segundo reator UASB bem como do reator aerado e do sistema global foram de 58,62, 65 e 72\%, respectivamente. A concentração de DQO afluente do sistema era de 20.000 mg/L. Neste trabalho podese observar que a eficiência de remoção da matéria orgânica aumentou com o aumento da carga orgânica volumétrica aplicada $\left(\mathrm{kg} \mathrm{DQO} \cdot \mathrm{m}^{-3} \cdot \mathrm{d}^{-1}\right)$. Este fato atesta que os sistemas anaeróbios são mais eficientes quando submetidos a altas cargas orgânicas. A eficiência na remoção de $\mathrm{N}^{-\mathrm{NH}_{4}}{ }^{+}$, do sistema como um todo foi acima de $99 \%$.

CASTILLO; VERGARA; MORENO (2006) também realizaram trabalho para avaliar a remoção de matéria orgânica em um reator UASB tratando lixiviado de aterro. Nesta pesquisa o reator UASB foi operado com vários tempos de detenção hidráulica. A 
máxima eficiência na remoção de DQO foi de $62 \%$ para o TDH de 54 h e uma carga orgânica volumétrica de $3273 \mathrm{~g} \mathrm{DQO} \cdot \mathrm{m}^{-3} \cdot \mathrm{d}^{-1}$. A eficiência na remoção de matéria orgânica aumentou com o aumento do TDH, demonstrando que quanto maior 0 tempo de contato entre o efluente e os microrganismos presentes na manta de lodo do reator UASB, maior será a remoção de matéria orgânica. A produção específica de metano encontrada, para o TDH de $54 \mathrm{~h}$, foi de $0.29 \mathrm{~m}^{3}-\mathrm{CH}_{4} \cdot \mathrm{Kg}_{-} \mathrm{DQO}{ }^{-1}$ removida.

Importantes considerações devem ser levadas em conta no desenvolvimento de sistemas anaeróbios e aeróbios associados para serem utilizados no tratamento de lixiviado de aterro, principalmente no sentido de se evitar a inibição do processo de nitrificação.

Apesar de o processo anaeróbio ser mais eficiente a "altas" temperaturas, o mesmo pode ser também operado a baixas temperaturas. Em pesquisa realizada por KETTUNEN; RINTALA (1998) um reator UASB foi utilizado para o tratamento de percolado de aterro a temperaturas relativamente baixas $\left(13-23^{\circ} \mathrm{C}\right)$. A eficiência na remoção de $\mathrm{DQO}$ foi de $50-55 \%$ para uma temperatura de $13-14^{\circ} \mathrm{C}$ e uma carga orgânica volumétrica aplicada de $2 \mathrm{~kg}-\mathrm{DQO} \cdot \mathrm{m}^{-3} \cdot \mathrm{d}^{-1}$. Já para a temperatura de $20^{\circ} \mathrm{C} \mathrm{e}$ carga orgânica volumétrica de $4 \mathrm{~kg}$-DQO. $\mathrm{m}^{-3} \cdot \mathrm{d}^{-1}$, a eficiencia na remoção de DQO foi de $75 \%$. Apesar do inóculo do reator UASB ser um lodo digerido mesofílico $\left(37^{\circ} \mathrm{C}\right)$, houve uma boa adaptação do mesmo a baixas temperaturas, sendo este fato confirmado pelo aumento significativo da atividade metanogênica mesmo para baixas temperaturas $\left(11^{\circ} \mathrm{C}\right)$.

Filtro anaeróbio: os filtros anaeróbios são reatores preenchidos com material suporte inerte. Os microrganismos crescem aderidos ao meio suporte, assim como nos filtros aerados, formando um biofilme. Os filtros anaeróbios são geralmente de fluxo ascendente, podendo em alguns casos ser de fluxo descendente (JORDÃO; PESSÔA, 2005).

No filtro anaeróbio, o lodo é imobilizado pela sua agregação ao material de enchimento. A água residuária escoa pelos vazios entre o material suporte. Nos primeiros filtros anaeróbios usava-se como material de enchimento rochas vulcânica, mas com a evolução do processo os materiais passaram a ser também utilizados 
como material suporte, de maneira a propiciar uma maior área específica para a aderência do lodo, aumentando assim o contato entre o lodo e o material orgânico afluente (VAN HAANDEL; MARAIS, 1999).

Segundo VAN HAANDEL; MARAIS (1999) existem algumas desvantagens no uso de filtros anaeróbios tais como: 1) alto custo do material de enchimento, que se equivale ao custo de construção do reator 2) ocorrência de entupimentos, principalmente quando o efluente tem uma alta concentração de sólidos em suspensão.

Os filtros anaeróbios de fluxo ascendente podem ser aplicados no tratamento de lixiviado, principalmente com o objetivo de remoção de matéria orgânica.

CHANG (1989) operou um filtro anaeróbio com o objetivo de avaliar a remoção de matéria orgânica de lixiviado de aterro (aterro novo com grande parcela de matéria orgânica biodegradável). Para uma temperatura de $35^{\circ} \mathrm{C}$ e uma carga orgânica volumétrica de $13 \mathrm{~kg}$-DQO $\cdot \mathrm{m}^{-3} \cdot \mathrm{d}^{-1}$, a eficiência na remoção de DQO solúvel foi maior que $92 \%$ porém, quando a carga orgânica volumétrica foi aumentada para $21,7 \mathrm{~kg}$ DQO. $\mathrm{m}^{-3} \cdot \mathrm{d}^{-1}$ esta eficiência caiu para $70 \%$. Neste trabalho também foi observado, um grande acúmulo de ferro no sistema no final do período de operação.

BIDONE et al. (2007) operaram dois filtros anaeróbios de fluxo ascendente em escala real, com objetivo principal de avaliar a remoção de matéria orgânica presente no lixiviado de aterro sanitário. Os filtros foram operados em série e tinham como material de enchimento brita $n^{0} 3$. A eficiência média de remoção global do sistema foi de 59\% em termos de DBO, 55\% em termos de DQO e $53 \%$ em termos de COT. A maior redução de matéria orgânica se deu no primeiro filtro, sendo que no segundo filtro essa redução foi quase insignificante. Este resultado mostra que não é interessante a operação de dois filtros anaeróbios em série para o tratamento do lixiviado em questão. 


\subsubsection{TRATAMENTo FísıCo-Químico}

O tratamento físico-químico consiste na adição de produtos químicos no afluente de maneira a melhorar a remoção de contaminantes, sendo que esta adição é quase sempre acompanhada de um processo físico. Assim, o tratamento físico é sempre usado em conjunção com o químico bem como com o tratamento biológico (QASIM; CHIANG, 1994).

Com o processo de estabilização dos aterros sanitários, a proporção de compostos facilmente biodegradáveis no lixiviado diminui, provocando assim uma diminuição na eficiência dos processos biológicos de tratamento. Essa diminuição se dá devido a decomposição anaeróbia que ocorre na massa de lixo e com isso, a matéria orgânica existente no percolado possui uma grande parcela de compostos refratários. Estes compostos são difíceis de serem assimilados pelos microrganismos presentes comumente em sistemas biológicos. Portanto, o uso de outros tipos de tratamento complementares ao biológico como, o físico-químico, fazse necessário (QASIM; CHIANG, 1994; McBEAN; ROVERS; FURQUHAR, 1995).

O uso de processos físico-químicos como única alternativa de tratamento é indicado somente quando o lixiviado é provindo de um aterro muito "velho" (McBEAN; ROVERS; FURQUHAR, 1995).

De acordo com QASIM; CHIANG (1994); McBEAN; ROVERS; FURQUHAR (1995) os principais tratamentos físico-químicos utilizados para percolado de aterro sanitário são:

- Tratamentos químicos: coagulação e precipitação, adsorção por carvão e oxidação química;

- Tratamentos físicos: arraste com ar (Air "stripping"), floculação e sedimentação, osmose reversa e ultrafiltração.

Coagulação, floculação, precipitação e sedimentação: os princípios destes processos estão completamente desenvolvidos sendo que, os mesmos são comumente utilizados no tratamento de uma infinidade de efluentes industriais, bem como de esgoto doméstico. Apesar da coagulação, floculação, precipitação e sedimentação serem processos individuais, eles estão correlacionados e geralmente 
são combinados formando um único sistema de tratamento No lixiviado estes processos são geralmente utilizados para a remoção de matéria orgânica e metais pesados (QASIM; CHIANG, 1994; McBEAN; ROVERS; FURQUHAR, 1995).

AMOKRANE; COMEL; VERON (1997) estudaram a utilização da coagulação floculação como pré-tratamento de lixiviado de aterro. Para isso foram executados vários ensaios de "jar-test" a fim de se determinar a melhor dosagem de coagulante para o tratamento eficiente do lixiviado. Os coagulantes usados foram cloreto férrico e sulfato de alumínio. Os resultados indicaram que a dosagem ótima tanto para o cloreto férrico como para o sulfato de alumio foi similar, ficando em torno de 0,035 mol. $L^{-1}$. Contudo, para a mesma dosagem, as eficiências obtidas com o cloreto férrico foram superiores. As eficiências médias na remoção de DQO e turbidez, para o cloreto férrico, foram de $94 \%$ e $55 \%$ respectivamente, e $42 \%$ e $87 \%$ e para o sulfato de alumínio. $\mathrm{O} \mathrm{pH}$ ótimo, referente a maior eficiência de remoção e a dosagem ótima, foi de 5 para o cloreto férrico e 5,5 para o sulfato de alumínio, sendo que houve um decréscimo na eficiência de remoção, tanto de DQO como de turbidez, com o aumento do $\mathrm{pH}$.

Adsorção por carvão ativado: Uma grande variedade de compostos orgânicos e inorgânicos podem ser removidos de efluentes através da adsorção por carvão ativado. O carvão ativado possui uma alta área superficial adsorvente (500-1500 $\left.\mathrm{m}^{2} \cdot \mathrm{g}^{-1}\right)$. Este processo de tratamento, geralmente, é mais eficiente no tratamento de efluentes que tenham compostos com baixa solubilidade em água, alto peso molecular, baixa polaridade e baixo grau de ionização. Alguns compostos orgânicos biorefratários podem também ser removidos através da adsorção em carvão ativado (QASIM; CHIANG, 1994).

Uma das desvantagens da utilização deste tratamento é que, para efluentes com grande quantidade de matéria orgânica, é necessário o uso de grande quantidade de carvão. Além disso, o tratamento com este material é um processo de transferência, ou seja, a matéria orgânica não será oxidada e sim transferida de ambiente.

De acordo com McBEAN; ROVERS; FURQUHAR (1995) o tratamento utilizando carvão ativado, geralmente, ocorre em colunas que podem ser de fluxo ascendente ou de fluxo descendente. 
O uso do carvão ativado pode ser utilizado eficientemente na remoção de solventes e compostos tóxicos e refratários, muitos destes encontrados no lixiviado de aterro sanitário (QASIM; CHIANG, 1994; McBEAN; ROVERS; FURQUHAR, 1995).

Como já reportado anteriormente no item 3.5.1.1 (lodos ativados em bateladas seqüenciais), o uso de carvão ativado granulado pode aumentar a eficiência na remoção de matéria orgânica e nitrogênio amoniacal em sistemas tratando percolado de aterro sanitário.

RODRÍGUEZ et al. (2004) realizaram trabalho para avaliar a remoção da matéria orgânica presente em percolado de aterro sanitário; para isso o lixiviado foi submetido a ação de vários materiais adsorventes, dentre eles o carvão ativado e algumas resinas (XAD-4, XAD-8). Os resultados demonstraram que a maior eficiência na remoção de DQO (>80\%), foi obtida quando se utilizou o carvão ativado. O tempo de contato entre o lixiviado e o carvão ativado foi de $2 \mathrm{~h}$, sendo que para tempos maiores que este não houve aumento significativo na remoção de matéria orgânica.

Processos Oxidativos: os processos de oxidação química foram usados, inicialmente, em processos industriais com o objetivo de se destruir cianetos, fenóis e outros compostos orgânicos (QASIM; CHIANG, 1994).

A oxidação química pode ser usada como pré-tratamento no sentido de eliminar constituintes que podem atrapalhar outros métodos de tratamento; ou então podem ser utilizados como pós-tratamento, objetivando a remoção dos traços de contaminantes provindos do tratamento anterior (QASIM; CHIANG, 1994).

Nos últimos anos, inúmeros trabalhos vêm sendo desenvolvidos com o objetivo de se tratar liquidos percolados de aterros sanitários utilizando processos oxidativos.

Os processos oxidativos são usados principalmente no tratamento de lixiviado provindo de aterro sanitário já estabilizado (lixiviado "velho"), já que o mesmo possuiu uma grande parcela de compostos recalcitrantes que, geralmente, não são removidos em tratamentos biológicos (WANG; SMITH; GAMAL EL-DIN, 2003).

Os chamados processos oxidativos avançados também podem ser utilizados no tratamento de lixiviado. O principal objetivo da aplicação de processos oxidativos 
avançados em lixiviado de aterro é remoção dos compostos recalcitrantes ou então, transformar estes compostos em substâncias que podem ser removidas mais facilmente em tratamentos biológicos subseqüentes (WANG; SMITH; GAMAL ELDIN, 2003).

De Acordo com WANG; SMITH; GAMAL EL-DIN, (2003), os principais agentes oxidantes utilizados nos processos oxidativos avançados são, ozônio com peróxido de hidrogênio, ozônio com luz ultravioleta, peróxido de hidrogênio com luz ultravioleta, o processo fenton e o processo photo-fenton.

WU et al. (2003) utilizou o ozônio $\left(\mathrm{O}_{3}\right)$ combinado com UV, para o tratamento de lixiviado de aterro pré-tratado (coagulação-floculação com adição de cloreto férrico). Os resultados mostraram que, após o tratamento $\left(\mathrm{O}_{3}+\mathrm{UV}\right)$, a porcentagem de compostos de altíssimo peso molecular (> $10 \mathrm{kDa}$ ), decresceram de $34 \%$ para $9 \%$, para uma dosagem aplicada de $1,2 \mathrm{~g}^{\mathrm{I}^{-1}}$ de $\mathrm{O}_{3}$ (lâmpada de $200 \mathrm{~W}$ ). Este fato contribuiu para que a relação $\mathrm{DBO} / \mathrm{DQO}$, do lixiviado pré-tratado, passasse de 0,1 para 0,5 após o tratamento, demonstrando assim o aumento da biodegradabilidade do lixiviado quando submetido a este tipo de processo.

Arraste com ar (Air "stripping"): o arraste com ar é um processo que transfere contaminantes da fase líquida para a fase gasosa (ar). Os contaminantes não são eliminados nos processos de arraste com ar e, sim, separados fisicamente da fase líquida.

O arraste é utilizado na remoção de compostos voláteis como a amônia e os compostos orgânicos voláteis (COV's) (QASIM; CHIANG, 1994; McBEAN; ROVERS; FURQUHAR, 1995).

No processo de Air "stripping" para a remoção de nitrogênio amoniacal o efluente tem o seu pH inicialmente elevado (aproximadamente 11-12) com o auxílio de algum tipo de alcalinizante (cal hidratada ou soda caustica). Com este valor de $\mathrm{pH}$, o íon amônio converte-se quase que totalmente à forma gasosa, $\mathrm{NH}_{3}$. Após este processo, o efluente é distribuído sobre torres de gotejamento, que podem ser preenchidas com material constituído de PVC (barras cilíndricas ou de seção triangular). O gotejamento provocado pelo contato da água com o material de 
enchimento das colunas facilita o araste da amônia, que pode ser recolhida em outra coluna, evitando assim a poluição do ar (PIVELI; KATO, 2006).

$\mathrm{Na}$ maioria dos efluentes o nitrogênio amoniacal pode estar presente na forma de gás $\left(\mathrm{NH}_{3}\right)$ ou nitrogênio na forma ionizada $\left(\mathrm{NH}_{4}{ }^{+}\right)$, o íon amônio. O equilíbrio entre a forma ionizada e a forma não ionizada, depende do $\mathrm{pH}$ conforme representado na Equação 15.

$$
\mathrm{NH}_{4}^{+}+\mathrm{OH}^{-} \leftrightarrow \mathrm{NH}_{3}+\mathrm{H}_{2} \mathrm{O}
$$

De acordo com MetCalf \& Eddy (2003) para valores de pH em torno 8, apenas 5,3\% da concentração do nitrogênio amoniacal se encontra na forma não ionizada e para valores de $\mathrm{pH}$ em torno de 10 , da concentração total de nitrogênio amoniacal, $85 \%$ se encontra na forma não ionizada, o que facilita o processo de "stripping" de amônia. Assim, quanto maior o pH do efluente melhor será a eficiência do processo de "stripping".

Apesar de ser uma alternativa para remoção de nitrogênio amoniacal, existem inúmeras limitações ao uso desta tecnologia dentre elas estão:

- Necessidade de múltiplos estágios para reduzir a concentração de nitrogênio a níveis apropriados para descarte;

- Altos custos operacionais devido a necessidade de adição de alcalinizantes (elevação do pH) bem como posterior adição de ácidos para correção do pH antes do descarte;

- Presença de incrustações nas torres de "stripping" e tubulações devido a formação de carbonato de cálcio e óxidos de ferro.

- Parada do processo para a limpeza das torres de "stripping" bem como das tubulações;

- Liberação de amônia na forma gasosa para a atmosfera, sendo este gás um potencial poluidor do meio ambiente bem como causador de doenças;

- Potencial liberação de odores. 
Um dos maiores problemas pertinentes aos líquidos percolados de aterro é a alta concentração de nitrogênio amoniacal. O "stripping" de amônia é um dos métodos utilizados para a diminuição desta alta concentração de nitrogênio amoniacal. No "stripping", o nitrogênio é transferido da massa líquida através do arraste com ar.

O principal objetivo do "stripping" de amônia é atenuar a concentração de nitrogênio amoniacal do lixiviado de maneira a melhorar a eficiência de remoção deste composto em sistemas biológicos de tratamento.

AMARAL et al. (2008) realizou trabalho para avaliar a biodegradabilidade anaeróbia de lixiviado quando submetido ao pré-tratamento por air "stripping" bem como do lixiviado bruto. Neste caso o lixiviado bruto teve o pH ajustado para 9,5 (adição de $\mathrm{NaOH}$ ) e posteriormente aerado por um período de $12 \mathrm{~h}$ sendo que, após o período aerado o pH foi novamente ajustado para 7 (adição de $\mathrm{H}_{3} \mathrm{PO}_{4}$ ). Os resultados deste trabalho demonstram uma remoção de $80 \%$ de amônia (concentração afluente igual a $1271 \mathrm{mg} / \mathrm{L}$ ) porém, houve uma pequena elevação na concentração de DQO e uma redução na concentração de DBO. Os valores da DBO e DQO afluente eram de 120 e 2443 mg/L respectivamente. Devido à redução da DBO a biodegradabilidade anaeróbia do lixiviado diminuiu (diminuição da produção de metano).

CHEUNG; CHU ; WONG (1997) estudaram o pré-tratamento de percolado de aterro através do processo de "stripping". Neste caso, o lixiviado foi submetido a diferentes vazões de ar (0,1 e $5 \mathrm{~L} / \mathrm{min})$. Os ensaios foram realizados com e sem a adição de alcalinizante (hidróxido de cálcio com concentração de $10.000 \mathrm{mg} / \mathrm{L}$ ). A maior redução na concentração de amônia foi para a vazão de $5 \mathrm{~L} / \mathrm{min}$ ( $90 \%$ de remoção). Já a remoção de DQO variou entre 24 e 47\%. Segundo os autores a remoção da DQO foi em conseqüência do processo de precipitação devido a adição de hidróxido de cálcio.

Além do $\mathrm{pH}$ a temperatura influência diretamente no processo de "stripping". LOPES et al. (2003) realizaram trabalho no intuito de verificar a influência da temperatura e do $\mathrm{pH}$ do lixiviado quando submetido ao processo de "stripping". Neste caso o lixiviado foi submetido a uma variação de $\mathrm{pH}$ entre 8 e 13 e uma variação de temperatura entre 25 e $55{ }^{\circ} \mathrm{C}$. Os resultados demonstram que o pH é mais influente na remoção de nitrogênio amoniacal do que a temperatura. Para este trabalho em específico, para um mesmo valor de $\mathrm{pH}$ (13) a remoção de nitrogênio amoniacal 
subiu de $46,8 \%$ para $58,3 \%$ quando a temperatura aumentou de $25{ }^{\circ} \mathrm{C}$ para $55{ }^{0} \mathrm{C}$, ou seja, um aumento de $11,5 \%$. Já para um mesmo valor de temperatura $\left(45^{\circ} \mathrm{C}\right)$, a remoção de nitrogênio amoniacal subiu de 3,6\% $(\mathrm{pH}=8)$ para 56,4\% $(\mathrm{pH}=13)$, ou seja, um aumento de 52,8\%. Neste caso a concentração afluente de nitrogênio amoniacal era de $1000 \mathrm{mg} / \mathrm{L}$.

Osmose reversa: A osmose reversa é um processo de desmineralização geralmente utilizado na produção de água de alta qualidade. O processo consiste em permear o liquido através de uma membrana semipermeável a altas pressões (acima de $10.000 \mathrm{kN} \cdot \mathrm{m}^{-2}$. As membranas usadas no processo podem ser de vários materiais sendo os mais comuns, o acetato de celulose e a poliamida (nylon) (QASIM; CHIANG, 1994).

QASIM; CHIANG, (1994); McBEAN; ROVERS; FURQUHAR, (1995) relatam que o processo de osmose reversa geralmente necessita de um pré-tratamento, principalmente para o ajuste do $\mathrm{pH}$ e retirada de compostos que prejudiquem a membrana. A remoção de alguns metais, como ferro e magnésio, para diminuir a formação de incrustações no sistema também é necessária.

CHIANESE; RANAURO; VERDONE (1998) em experimento realizado, com o objetivo de avaliar o tratamento de lixiviado de aterro em um sistema de osmose reversa, relataram que a eficiência na remoção de metais pesados, em especial Zinco, Cobre e Cadmo, diminuiu com o aumento da concentração de DQO do lixiviado. Além disso, a remoção de DQO aumentou com o também aumento da pressão de operação do sistema de osmose reversa.

\subsubsection{TRATAMENTO DO LIXIVIADO JUNTAMENTE COM ESGOTO DOMÉSTICO}

O tratamento do lixiviado de aterro juntamente com esgoto doméstico tem se mostrado uma boa alternativa, principalmente, quando o sistema está localizado próximo ao aterro, já que com o aumento da vazão do percolado com o tempo, o custo de transporte pode tornar esta alternativa inviável. Além desta, outras considerações devem ser levadas em conta quando se pretende tratar o lixiviado de aterro juntamente com o esgoto doméstico, dentre elas estão: a capacidade do sistema assimilar a vazão de lixiviado, possíveis depreciações dos componentes do sistema de tratamento pelos compostos presentes no percolado, compatibilidade do 
sistema com as características do lixiviado e a capacidade de tratamento do lodo, que terá sua produção aumentada (QASIM; CHIANG, 1994; McBEAN; ROVERS; FURQUHAR, 1995).

De acordo com McBEAN; ROVERS; FURQUHAR (1995), o tratamento dado ao lixiviado em sistemas de tratamento de esgotos domésticos tem como função a remoção de $\mathrm{DBO}$ e sólidos em suspensão, remoção de $\mathrm{N}-\mathrm{NH}_{3}$, desinfecção e adsorção/precipitação de alguns metais. Os impactos no sistema de tratamento de esgoto, provocados pelos constituintes do lixiviado, geralmente são pequenos devido ao fator de diluição, contudo este fator é limitado.

Vários autores têm tentado determinar a proporção de lixiviado que pode ser adicionada ao sistema de tratamento de esgotos domésticos, porém esta relação pode variar de acordo com o percolado.

ÇEÇEN; ÇAKIROGLU (2001) reportaram que, para o caso estudado, a fração máxima de lixiviado que pode ser tratada com esgoto doméstico foi de $20 \%(\mathrm{v} / \mathrm{v})$, sendo que para frações maiores que esta, o tratamento sofreu inibição; este fato pode ter sido causado pela alta concentração de compostos refratários encontrada no efluente. $O$ processo de nitrificação foi intenso, ocasionando assim uma alta eficiência na remoção de nitrogênio amoniacal.

\subsubsection{USO DO ATERRO COMO UM BIOREATOR}

Uma das alternativas de tratamento do lixiviado é a sua recirculação para dentro da massa de lixo, provocando assim uma nova percolação do mesmo através do aterro. A recirculação faz com que o aterro funcione como um digestor anaeróbio não controlado, acelerando assim a estabilização dos compostos orgânicos presentes no lixiviado. O uso da recirculação não elimina a necessidade de tratamento do percolado, já que o excesso do mesmo deverá ser tratado (QASIM; CHIANG, 1994; McBEAN; ROVERS; FURQUHAR, 1995).

Segundo McBEAN; ROVERS; FURQUHAR (1995) a recirculação do lixiviado pode ser feita durante os primeiros anos de funcionamento do aterro quando a produção de percolado é baixa ou então nula. Pode-se também usar a recirculação para se 
evitar problemas com o transporte do lixiviado, principalmente em finais de semana, ou então problemas causados por picos excessivos na produção do percolado.

QASIM; CHIANG (1994); McBEAN; ROVERS; FURQUHAR (1995) afirmam que as principais vantagens da utilização da recirculação do lixiviado em aterros sanitários são:

- Aceleração do processo de estabilização do aterro;

- Redução sustentada de compostos orgânicos do lixiviado;

- Adiamento do início do tratamento do lixiviado;

- Redução nos custos de tratamento do lixiviado, além de o processo ser considerado um tratamento de baixo custo;

- Melhora nas taxas de produção do gás metano.

BERGE et al. (2007) estudaram dois aterros sanitários em escala piloto operados como biorreatores e submetidos a diferentes temperaturas. Os resultados revelaram uma completa remoção do nitrogênio presente no lixiviado. O percolado foi produzido nos próprios aterros avaliados e posteriormente recirculado para dentro da massa de lixo. A remoção do nitrogênio foi obtida, em sua maioria, pelo processo de nitrificação/desnitrificação, sendo que as taxas de desnitrificação decresceram com o aumento da temperatura do aterro. $\mathrm{O}$ aumento da temperatura fez com que a taxa de nitrificação também aumentasse, provocando assim uma alta concentração de nitrato no meio, sendo este fato uma possível explicação para a inibição do processo de desnitrificação. A presença de zonas anóxicas e aeradas dentro da massa de lixo, contribuíram para o estabelecimento do processo de nitrificação/desnitrificação, sendo que o suprimento de oxigênio no aterro foi mantido pela introdução artificial de ar. 


\subsection{REMOÇÃO BIOLÓGICA DO NITROGÊNIO}

\subsubsection{CICLO DO NITROGÊNIO}

O nitrogênio molecular $\left(N_{2}\right)$ representa a grande parte do nitrogênio existente na terra. A utilização desta forma de nitrogênio pelas plantas e algas pode se dar pelo processo de fixação biológica ou então pela ocorrência de reações químicas provocadas por descargas elétricas na atmosfera.

O nitrogênio orgânico constituinte do tecido de uma planta pode ser incorporado ao tecido animal através do processo de alimentação dos mesmos. A morte, seguida da decomposição de animais e vegetais, juntamente com as transformações sofridas pelos compostos orgânicos presentes nos esgotos, provocam a formação de nitrogênio amoniacal nas águas. $\mathrm{O}$ nitrogênio amôniacal presente na água pode sofrer um processo de oxidação biológica, convertendo-se a nitrito $\left(\mathrm{NO}_{2}{ }^{-}\right)$e posteriormente a nitrato $\left(\mathrm{NO}_{3}{ }^{-}\right)$. O processo de oxidação da amônia a nitrito é executado, em sua maioria, por um grupo de bactérias denominadas Nitrosomonas $s p$, já as bactérias conhecidas como Nitrobacter $s p$ são as responsáveis pela conversão do nitrito a nitrato, sendo todo este processo conhecido como nitrificação. O processo de nitrificação ocorre somente em meio aeróbio. Completando o ciclo, o nitrogênio oxidado $\left(\mathrm{NO}_{2}{ }^{-}, \mathrm{NO}_{3}{ }^{-}\right)$é reduzido a nitrogênio gasoso $\left(\mathrm{N}_{2}\right)$ por microrganismos heterotróficos facultativos, em ambientes com ausência de oxigênio molecular, conhecidos também como anóxicos (PIVELI; KATO 2006).

As atividades antrópicas tem uma grande parcela de contribuição no aporte de nitrogênio em águas naturais, dentre estas atividades se destacam: esgotos domésticos; escoamento das águas pluviais pelos solos fertilizados com produtos ricos em amônia; águas residuárias oriundas da degradação do lixo urbano (lixiviado de aterro) (PIVELI; KATO 2006).

A figura 6 mostra o ciclo do nitrogênio na natureza. 


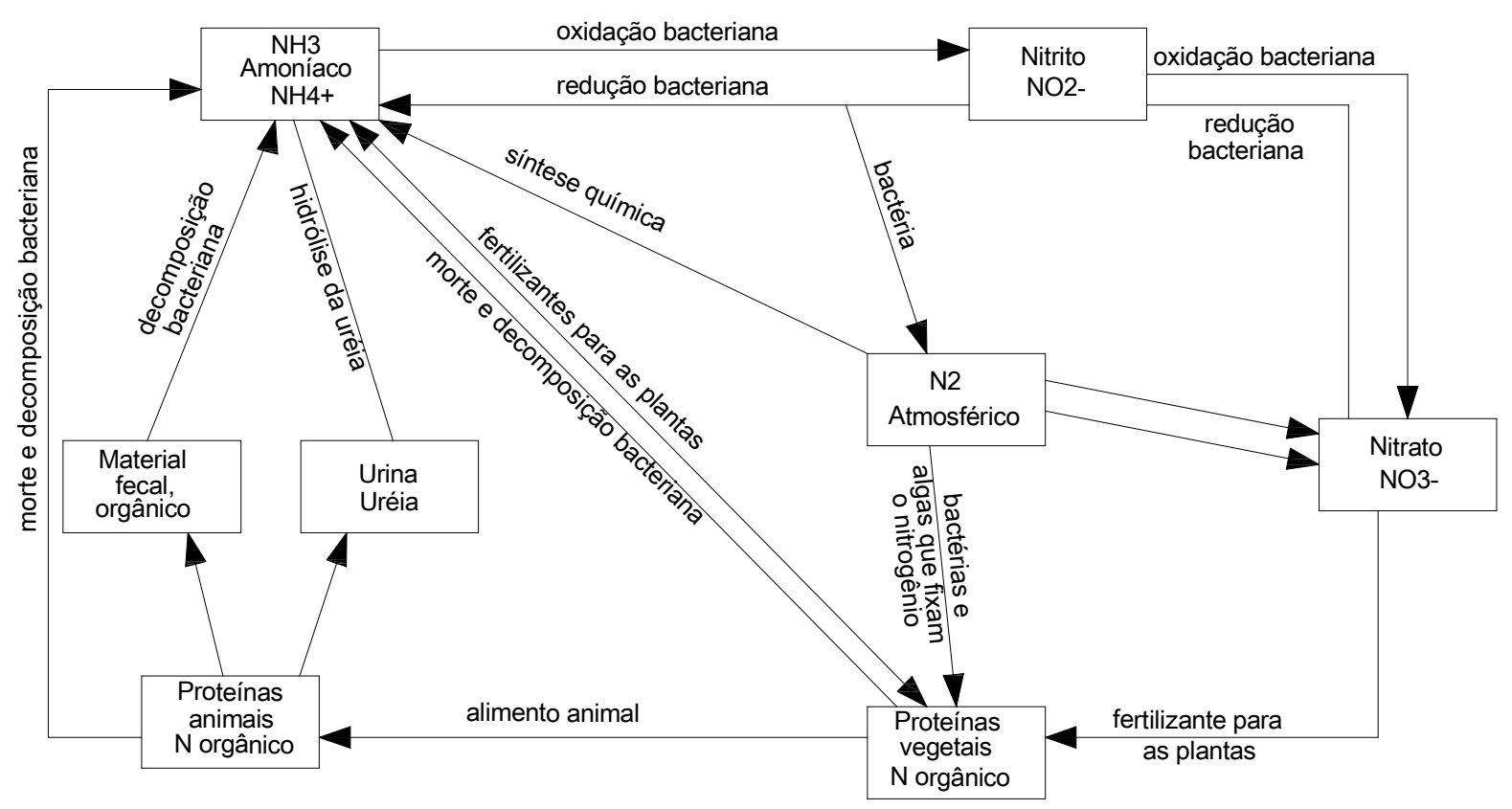

Figura 6 - Ciclo do nitrogênio na natureza. Fonte: METCALF \& EDDY 2003

\subsubsection{Problemas causados pelo lançamento de nitrogêNio em águas NATURAIS}

Um dos objetivos do tratamento de águas residuárias é a redução da carga orgânica presente nos despejos. Com o passar do tempo descobriu-se que, somente a redução de matéria orgânica não era suficiente para manter o equilíbrio do ambiente aquático, que é o principal receptor dos lançamentos de efluentes. Com isso foi necessário desenvolver tratamentos que minimizassem a concentração de macronutrientes, principalmente nitrogênio e fósforo, presentes nos despejos.

O lançamento sem controle de compostos nitrogenados presentes em águas residuárias podem causar os seguintes prejuízos (PIVELI; KATO, 2006):

1. Quando descarregado nas águas naturais juntamente com outros macronutrientes, podem provocar o enriquecimento do meio tornando-o mais fértil ocasionando assim o crescimento excessivo de alguns seres vivos, especialmente algas, processo este conhecido como eutrofização. A morte seguida da decomposição destes organismos causa a poluição do ambiente aquático, além de consumir o oxigênio dissolvido do meio. 
2. Aumento da demanda de desinfectante nas estações de tratamento de água (ETA's) já que o cloro reage com o íon amônio $\left(\mathrm{NH}_{4}{ }^{+}\right)$formando cloraminas que são desinfectantes menos eficazes que o ácido hipocloroso.

3. Toxicidade a vida aquática, já que algumas espécies não suportam concentrações acima de $0,1 \mathrm{mg} / \mathrm{L}$ de $\mathrm{N}-\mathrm{NH}_{3}$.

4. O nitrato é tóxico, causando uma doença denominada Metaemoglobinemia infantil, que é letal para crianças. O nitrato é reduzido a nitrito na corrente sanguínea, competindo com o oxigênio livre e incapacitando a troca de oxigênio.

\subsubsection{CONTROLE DO NITROGÊNIO PERANTE A LEGISLAÇÃO}

Os órgãos ambientais, com o intuito de evitar problemas de saúde pública, regulamentam o lançamento de efluentes contendo nitrogênio.

A resolução $n^{0} 357$ de 17 de março de 2005 elaborada pelo Conselho Nacional do Meio Ambiente (CONAMA), que dispõe sobre a classificação dos corpos de água e dá diretrizes ambientais para o seu enquadramento, bem como estabelece as condições e padrões de lançamento de efluentes, estabelece como limite para o lançamento de nitrogênio amoniacal total, uma concentração inferior a $20 \mathrm{mg} \mathrm{N} / \mathrm{L}$. Contudo, a resolução CONAMA 397/08 não mais estabelece limite para o lançamento de nitrogênio amoniacal para efluentes exclusivamente domésticos.

É importante ressaltar que a resolução CONAMA 357 permite aos órgãos ambientais estaduais adotarem valores mais restritivos que o estabelecido, quando comprovados efeitos tóxicos e agudos em organismos aquáticos ou inviabilizar o abastecimento às populações; da mesma forma, a resolução permite a adoção de valores mais elevados do que o preconizado, associando testes ecotoxicológicos, toxicológicos e estudo de dispersão no corpo receptor, de maneira a não prejudicar os usos previstos para o corpo d'água.

A resolução CONAMA 357 por meio do artigo $32, \S 1^{0}$, estabelece que o lançamento de efluentes deve atender simultaneamente às condições e padrões de lançamento de efluentes e não ocasionar a ultrapassagem das condições e padrões de qualidade da água, estabelecidos para as respectivas classes, nas condições e 
vazões de referência. Os padrões estabelecidos para os cursos d'água, relativos as formas de nitrogênio, podem ser vistos na tabela 1.

Tabela 2 - Padrões de qualidade das formas de nitrogênio para os cursos d'água

\begin{tabular}{cccc}
\hline Parâmetro Águas doces Classe 1 e 2 & $\begin{array}{c}\text { Águas Salinas } \\
\text { Classe 1 }\end{array}$ & $\begin{array}{c}\text { Águas Salobras } \\
\text { Classe 1 }\end{array}$ \\
\hline Nitrato & $10,0 \mathrm{mg} \mathrm{N} / \mathrm{L}$ & $0,40 \mathrm{mg} \mathrm{N} / \mathrm{L}$ & $0,40 \mathrm{mg} \mathrm{N} / \mathrm{L}$ \\
\hline Nitrito & $1,0 \mathrm{mg} \mathrm{N} / \mathrm{L}$ & $0,07 \mathrm{mg} \mathrm{N} / \mathrm{L}$ & $0,07 \mathrm{mg} \mathrm{N} / \mathrm{L}$ \\
\hline & $\begin{array}{c}3,7 \mathrm{mg} \mathrm{N} / \mathrm{L}, \text { para } \mathrm{pH}<7,5 \\
\mathrm{mg} \mathrm{N} / \mathrm{L}, \text { para } 7,5<\mathrm{pH} \\
<8,0\end{array}$ & \\
$\begin{array}{c}\text { Nitrogênio } \\
\text { Amoniacal } \\
\text { Total }\end{array}$ & $\begin{array}{c}2,0 \mathrm{mg} \mathrm{N} / \mathrm{L}, \text { para } 8,0<\mathrm{pH} \\
<8,5\end{array}$ & $0,40 \mathrm{mg} \mathrm{N} / \mathrm{L}$ & $0,40 \mathrm{mg} \mathrm{N} / \mathrm{L}$ \\
& $0,5 \mathrm{mg} \mathrm{N} / \mathrm{L}$, para $\mathrm{pH}>8,5$ & & \\
\hline
\end{tabular}

Fonte: Adaptado Brasil 2005

O estado de São Paulo por meio do decreto $n^{0}$ 8.468, de 8 de setembro de 1976, que dispõe sobre a prevenção e o controle de poluição das águas, preconiza em seu artigo 18, a definição dos padrões de emissão para efluentes de qualquer fonte poluidora lançados, direta ou indiretamente, nas coleções de água. Além de obedecerem aos limites deste artigo, os efluentes não poderão conferir ao corpo receptor características em desacordo com o enquadramento do mesmo, na classificação das águas. A tabela 2 traz os padrões de qualidade para o nitrogênio em água doce classe 2.

Tabela 3 - Padrões de lançamento para as formas do nitrogênio para corpos d'água classe 2 no estado de São Paulo

\begin{tabular}{cc}
\hline Parâmetro & Águas doces Classe 2 \\
\hline Nitrato & $10,0 \mathrm{mg} \mathrm{N} / \mathrm{L}$ \\
\hline Nitrito & $1,0 \mathrm{mg} \mathrm{N} / \mathrm{L}$ \\
\hline Amônia & $0,5 \mathrm{mg} \mathrm{N} / \mathrm{L}$ \\
\hline
\end{tabular}

Fonte: Adaptado do Decreto 8.468 de 8 de setembro de 1976, do estado de São Paulo 


\subsubsection{REMOÇÃO BIOLÓGICA DO NITROGÊNIO PRESENTE EM ÁGUAS RESIDUÁRIAS}

A remoção de nitrogênio depende dos objetivos a serem alcançados pelo tratamento bem como da necessidade de se adequar o despejo aos padrões de qualidade preconizados pelos órgãos ambientais.

A remoção biológica de nitrogênio é realizada em duas etapas, a nitrificação e a desnitrificação. No processo de nitrificação a amônia é oxidada a nitrato na presença de oxigênio (ambiente aeróbio). Já no processo de desnitrificação, o nitrato formado é utilizado como aceptor de elétrons para a respiração biológica, em ambiente com ausência de oxigênio molecular, provocando assim a redução do mesmo a nitrogênio molecular.

O processo de nitrificação é realizado por dois tipos de bactérias autotróficas, as bactérias que oxidam a amônia e as bactérias que oxidam nitrito. Recentemente, descobriu-se que além da espécie Nitrosomonas $s p$, a espécie Nitrosospira $s p$ é também responsável pela oxidação da amônia a nitrito. Na oxidação de nitrito a nitrato as espécies predominantes são a Nitrobacter sp e a Nitrospira sp. A maioria das bactérias nitrificantes é quimolito-autotróficas, ou seja, obtém todo o carbono necessário às suas atividades vitais a partir do $\mathrm{CO}_{2}$ (PHILIPS; LAANBROEK; VERSTRAETE, 2002).

A primeira etapa da nitrificação é a oxidação da amônia a nitrito tendo a hidroxilamina $\left(\mathrm{NH}_{2} \mathrm{OH}\right)$ como composto intermediário. Esta reação é endotérmica (equação 1). Depois dessa etapa, a hidroxilamina é convertida a nitrito usando o oxigênio como aceptor de elétrons, numa reação que gera energia (equação 2).

$$
\begin{aligned}
& \mathrm{NH}_{3}+\mathrm{O}_{2}+2 \mathrm{H}^{+}+2 \mathrm{e}^{-} \longrightarrow \mathrm{NH}_{2} \mathrm{OH}+\mathrm{H}_{2} \mathrm{O} \\
& \mathrm{NH}_{2} \mathrm{OH}+\mathrm{H}_{2} \mathrm{O} \longrightarrow \mathrm{NO}_{2}^{-}+5 \mathrm{H}^{+}+4 \mathrm{e}^{-} \\
& 0.5 \mathrm{O}_{2}+2 \mathrm{H}^{+} \longrightarrow 2 \mathrm{e}^{-}+\mathrm{H}_{2} \mathrm{O}
\end{aligned}
$$

$$
\mathrm{NH}_{3}+1.5 \mathrm{O}_{2} \longrightarrow \mathrm{NO}_{2}^{-}+\mathrm{H}^{+}+\mathrm{H}_{2} \mathrm{O}\left(\Delta \mathrm{G}=-275 \mathrm{~kJ} \mathrm{~mol} \mathrm{~N}^{-1}\right)
$$

Depois desta etapa, o nitrito é oxidado a nitrato (eq. 4). A reação geral da nitrificação bem como a geração total da energia do processo pode ser visualizada nas equações 5 e 6 . 
$\mathrm{NO}_{2}^{-}+\mathrm{H}_{2} \mathrm{O} \longrightarrow \mathrm{NO}_{3}^{-}+2 \mathrm{H}^{+}+2 \mathrm{e}^{-}$

$0.5 \mathrm{O}_{2}+2 \mathrm{H}^{+}+2 \mathrm{e}^{-} \longrightarrow \mathrm{H}_{2} \mathrm{O}$

$\mathrm{NO}_{2}^{-}+0.5 \mathrm{O}_{2} \longrightarrow \mathrm{NO}_{3}^{-}\left(\Delta \mathrm{G}=75 \mathrm{~kJ} \mathrm{~mol} \mathrm{~N}^{-1}\right)$

$\mathrm{NH}_{3}+2 \mathrm{O}_{2} \longrightarrow \mathrm{NO}_{3}^{-}+\mathrm{H}^{+}+\mathrm{H}_{2} \mathrm{O}\left(\Delta \mathrm{G}=350 \mathrm{~kJ} \mathrm{~mol} \mathrm{~N}^{-1}\right)$

O coeficiente de síntese celular dos microrganismos nitrificantes é baixo, isso pode ser explicado pelo fato de que $80 \%$ da energia gerada pelas bactérias que oxidam amônio é consumida para a fixação do $\mathrm{CO}_{2}$, sendo que para cada átomo de carbono fixado, as bactérias precisam oxidar 35 moléculas de $\mathrm{NH}_{3}$ ou então 100 moléculas de nitrito.

Levando em consideração as equações 1 a 6 e a figura 7, que mostra a variação do numero de oxidação do nitrogênio nos processos de nitrificação e desnitrificação, pode-se calcular o consumo de oxigênio para o processo de nitrificação.

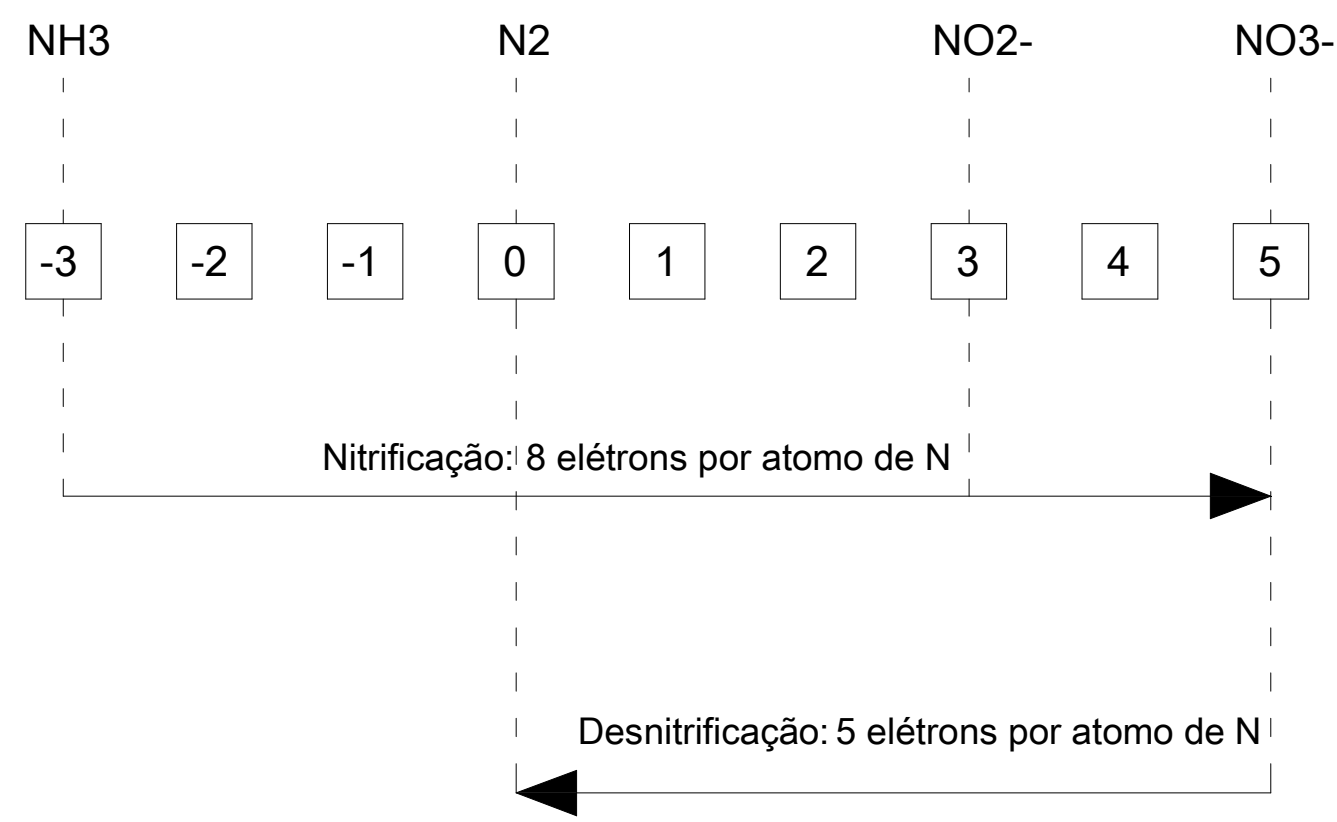

Figura 7 - Variação do número de oxidação do nitrogênio Fonte: adaptado de VAN HAANDEL: MARAIS, (1999).

Assim o consumo de oxigênio para a nitrificação é de $1 \mathrm{~mol} \mathrm{~N}-\mathrm{NH}_{3}=64 / 14=4,57$ $\mathrm{mg} \mathrm{O}_{2} / \mathrm{mg} \mathrm{N}$. 
O processo de nitrificação consome a alcalinidade do meio, este consumo pode ser estequiometricamente determinado. Na nitrificação há produção de dois mols de $\mathrm{H}^{+}$ por mol de nitrato formado. Levando em conta que a produção de $1 \mathrm{~mol}$ de $\mathrm{H}^{+}$é equivalente ao consumo de $1 \mathrm{~mol}$ de alcalinidade ou $50 \mathrm{~g} \mathrm{CaCO}_{3}$, para a nitrificação:

Variação de alcalinidade $=-100 / 14=-7,14 \mathrm{mg} \mathrm{CaCO} \cdot \mathrm{mg}^{-1} \cdot \mathrm{L}^{-1}$.

Outra fase do processo de remoção de nitrogênio é a desnitrificação. Nesta fase as formas oxidadas do nitrogênio (nitrato e nitrito), são reduzidas a nitrogênio gasoso por bactérias heterotróficas facultativas. Este processo ocorre na ausência de oxigênio molecular.

No processo de desnitrificação, cada óxido de nitrogênio é catalisado por uma enzima específica, geralmente referida como óxido de nitrogênio redutase (nitrito redutase, nitrato redutase, nitroso redutase, etc). Em cada fase do processo de redução, as formas oxidadas de nitrogênio servem como aceptoras de elétrons para a respiração, acompanhada da oxidação de compostos orgânicos como doadores de elétrons para a geração de energia e novas células (PHILIPS; LAANBROEK; VERSTRAETE, 2002).

Ainda de acordo com a figura 7, no processo de desnitrificação há uma transferência de 5 elétrons por átomo de nitrogênio na redução do oxidante nitrato para nitrogênio molecular, ou seja, 5 dos 8 elétrons liberados pelo nitrogênio amoniacal na sua oxidação para nitrato são recuperados. Assim uma fração igual a 5/8 do oxigênio necessário para a nitrificação pode ser recuperado como oxigênio equivalente no processo de desnitrificação $\left(5 / 8=0,625-0,625 * 4,57=2,86 \mathrm{mg} \mathrm{O}_{2} / \mathrm{mg} . \mathrm{N}\right)$.

Desta maneira, o consumo líquido de oxigênio para a remoção de nitrogênio, utilizando o processo de nitrificação e desnitrificação, é de:

$$
4,57-2,86=1,71 \mathrm{mg} \mathrm{O}_{2} / \mathrm{mg} \cdot \mathrm{N}
$$

Além da recuperação de oxigênio, a etapa de desnitrificação proporciona a recuperação de $1 \mathrm{~mol}$ de alcalinidade. Com isso pode-se concluir que o processo de nitrificação/desnitrificação apresenta um consumo de alcalinidade de $3,57 \mathrm{mg}$ $\mathrm{CaCO}_{3} / \mathrm{mg}$.N. Este fato aliado a também recuperação de oxigênio, demonstra que sistemas projetados com as etapas de nitrificação/desnitrificação podem ser mais 
econômicos do que os projetados somente com a etapa de nitrificação (VAN HAANDEL: MARAIS, 1999).

No processo de desnitrificação, algumas bactérias podem utilizar compostos inorgânicos como doadores de elétrons, como por exemplo, hidrogênio e amônia (BOCK; SCHMIDT; ZART, 1995).

Um processo diferente da desnitrificação pode ocorrer em sistemas de remoção de nitrogênio, sendo o mesmo conhecido como redução desassimilatória do nitrato; nele há a formação do íon amônio como produto final ao invés do $\mathrm{N}_{2}$, embora ambos os processos tem o nitrito como primeiro intermediário. O processo de redução desassimilatória do nitrato é realizado por bactérias fermentativas (Enterobacteriaceae, Aeromonas, Vibrio spp., Closteridium sp.) (PHILIPS; LAANBROEK; VERSTRAETE, 2002). A equação 7 caracteriza a reação ocorrida durante o processo.

$$
\mathrm{NO}_{3}{ }^{-}+4 \mathrm{H}_{2}+2 \mathrm{H}^{+} \longrightarrow \mathrm{NH}_{4}^{+}+3 \mathrm{H}_{2} \mathrm{O}
$$

As bactérias fermentativas do nitrato competem com as desnitrificantes. A redução desassimilatória é favorecida em ambientes nos quais a presença do aceptor de elétrons é limitada em relação ao doador de elétrons, ou seja, quando a concentração de nitrito e nitrato é baixa (PHILIPS; LAANBROEK; VERSTRAETE, 2002).

Outra reação semelhante à redução desassimilatória é a redução assimilatória do nitrato a íon amônio. Apesar da similaridade dos processos, as enzimas e as funções de cada um são diferentes. Na redução assimilatória, o íon amônio produzido é incorporado como tecido celular e utilizado como fonte complementar para os microrganismos (PHILIPS; LAANBROEK; VERSTRAETE, 2002).

Outro passo importante na remoção biológica de nitrogênio é se determinar o consumo de substrato para a desnitrificação. Os microrganismos heterotróficos, para obtenção de energia (catabolismo) e síntese de material celular (anabolismo), utilizam compostos orgânicos como fornecedores de elétrons em reações de oxiredução. Baseado em princípios termodinâmicos é possível determinar a fração da energia, presente nas moléculas de compostos orgânicos, que é transformada em 
biomassa, sendo esta fração denominada coeficiente de síntese celular (Y) (VAN HAANDEL; MARAIS, 1999).

Através do coeficiente de síntese celular $(\mathrm{Y})$ e da fração de DQO utilizada pelos microrganismos para o anabolismo $\left(\mathrm{f}_{\mathrm{CV}}\right)$ é possível se determinar as frações de DQO utilizadas pelos microrganismos heterotróficos em seus processos metabólicos. Considerando $\mathrm{Y}=0.45 \mathrm{mg} \mathrm{SSV} / \mathrm{mg} \mathrm{DQO} \mathrm{O}_{\text {consumida }}$ e $\mathrm{f}_{\mathrm{CV}}=1,48 \mathrm{mg} \mathrm{DQO} / \mathrm{mg} \mathrm{SSV}$, temse:

$$
f_{C V} \times Y=1,48 \times 0,45=0.67
$$

Assim $(1-0,67)=0.33$, podendo concluir que $2 / 3$ da DQO consumida nos sistemas de tratamento é sintetizada, enquanto $1 / 3$ é oxidada, consumindo oxigênio na

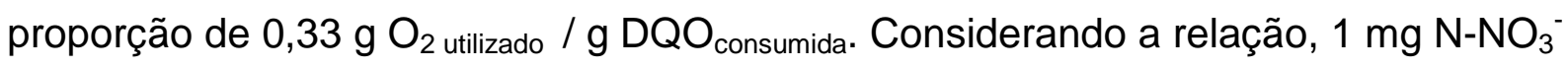
$\cong 2,86 \mathrm{mg} \mathrm{O}_{2}$, assim espera-se que o consumo teórico de substrato durante a desnitrificação seja igual á: $\mathrm{DQO}_{\text {consumida }}=\mathrm{mg} \mathrm{N}-\mathrm{NO}_{3}$ reduzido $\mathrm{X} 2,86 / 0.33 \cong 8.6 \mathrm{mg}$

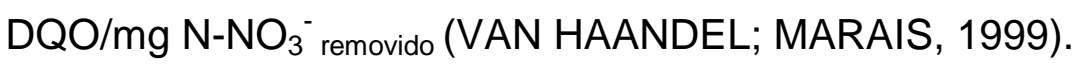

\subsubsection{Remoção biológica do nitrogênio via nitrito}

Os processos biológicos de tratamento, principalmente os que utilizam nitrificação e denitrificação, são uma boa alternativa para a remoção de nitrogênio. Contudo, estes processos podem acarretar em um aumento no volume total do reator (PENG et al., 2004).

Inicialmente o acúmulo de nitrito era considerado um efeito indesejado em sistemas de tratamento de efluentes, principalmente por sua potencial toxicidade, porém com o passar do tempo este processo passou a ser de interesse de muitos pesquisadores, devido à possibilidade de economia no dimensionamento de sistemas de aeração em estações de tratamento de efluentes.

Recorrendo-se as equações 1 e 2 e também a figura 7, nota-se que quando 0 nitrogênio é oxidado somente até nitrito e posteriormente reduzido a nitrogênio molecular, a economia de oxigênio requerida pode ser de $25 \%((1.5 \times 32) / 14)=3,43$ $\mathrm{mg} \mathrm{O}_{2} / \mathrm{mg} \mathrm{N}$. Além disso, dos 6 elétrons transferidos durante a etapa de oxidação da amônia a nitrito, três são recuperados no processo de desnitritação assim: 


$$
\left(\frac{3}{6}\right) \times 3,43 \mathrm{mg} \mathrm{O}_{2} \cdot \mathrm{mgN}^{-1}=1,71 \mathrm{mg} \mathrm{o}_{2} \cdot \mathrm{mgN}^{-1}
$$

Com isso o consumo teórico de DQO para a desnitritação é:

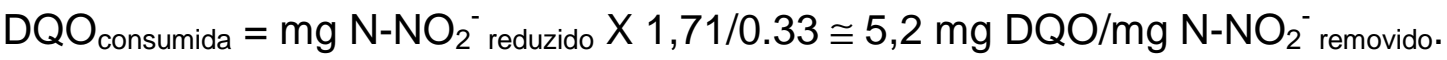

Considerando que o consumo de DQO para a desnitrificação completa é de $8.6 \mathrm{mg}$ $\mathrm{DQO} / \mathrm{mg} \mathrm{N}^{-N_{3}}{ }_{3}^{-}$removido, a economia de fonte de carbono quando se utiliza o processo de nitritação/desnitritação é igual a:

$\left(\frac{8,6-5,2}{8,6}\right) \times 100 \cong 40 \%$

Em alguns casos a relação $\mathrm{C} / \mathrm{N}$ do efluente é baixa, provocando a escassez da fonte de carbono necessária ao processo de desnitrificação. Assim a remoção de nitrogênio via nitritacão/desnitritação (via nitrito) pode ser uma boa alternativa para minimizar este problema (PENG et al., 2004).

Além do menor consumo de oxigênio e de substrato em relação a nitrificação completa, a remoção de nitrogênio pela via simplificada pode trazer outros benefícios como, maiores taxas de desnitrificação, menor produção de lodo na fase anóxica e redução nos volumes dos tanques de tratamento (TURK; MAVINIC, 1987).

\subsubsection{Acúmulo de nitrito em sistemas biológicos de tratamento de efluentes}

O acúmulo de nitrito é resultado, geralmente, de uma modificação na cinética de desenvolvimento das bactérias oxidantes de amônio bem como das bactérias oxidantes de nitrito. Como o nitrito é um intermediário tanto da nitrificação como da desnitrificação, ele pode acumular-se tanto em ambientes aeróbios como ambientes anóxicos. O nitrito pode ser produzido tanto através do amônio quanto através do nitrato, que pode ser reduzido, produzindo nitrito, através de uma infinidade de caminhos (PHILIPS; LAANBROEK; VERSTRAETE, 2002).

O desequilíbrio enzimático no desenvolvimento das bactérias responsáveis pelo processo de nitrificação/desnitrificação, resultando no acúmulo de nitrito, pode ser 
induzido através da manipulação de inúmeros parâmetros dentre eles: a concentração de amônio no afluente; idade do lodo; potencial hidrogeniônico (pH); temperatura; concentração de oxigênio dissolvido; presença de substâncias tóxicas; razão DQO/nitrogênio e tipo de operação do sistema de tratamento (contínuo ou em bateladas seqüenciais) (MARTIENSSEN; SCHOPS, 1996; GÓRSKA; CICHO; MIKSCH, 1997; PHILIPS; LAANBROEK; VERSTRAETE, 2002; AKERMAN, 2005; KIM, D.; KIM, S., 2006; QUEIROZ 2006; CIUDAD et al., 2007).

ANTHONISEN et al (1976) descreveram que o acúmulo de nitrito poderia estar relacionado com as concentrações de amônia livre a ácido nitroso $\left(\mathrm{HNO}_{2}\right)$, sendo que certas concentrações destes compostos poderiam ser inibitórias a todo o processo de nitrificação. Este trabalho permitiu ainda a descoberta de informações importantes ao processo de nitrificação, dentre elas se destacam:

- As concentrações inibitórias de amônia livre para as bactérias que oxidam a amônia ficaram em torno de 10 a $150 \mathrm{mg} \mathrm{NH} / \mathrm{L}$, já para as bactérias que oxidam o nitrito, esta concentração foi de 0,1 a $10 \mathrm{mg} \mathrm{NH} / \mathrm{L}$. Este fato demonstra que a concentração inibitória para as oxidantes de amônia foi maior que as encontradas para as oxidantes de nitrito.

- A inibição dos organismos nitrificantes, em geral, deu-se para concentrações de ácido nitroso entre 0,22 e 2,8 $\mathrm{mg} \mathrm{HNO}_{2} / \mathrm{L}$.

- Fatores como adaptação dos microrganismos e temperatura, afetaram as concentrações inibitórias de amônia livre e de ácido nitroso.

- Os modelos de nitrificação podem ser modificados, através de alterações em seus parâmetros operacionais, de maneira a diminuir ou aumentar os efeitos da inibição do processo devido a presença de ácido nitroso ou amônia livre.

O equilíbrio da amônia livre pode ser representada pela equação de equilíbrio 11.

$$
\mathrm{NH}_{4}{ }^{+}+\mathrm{OH}^{-} \longrightarrow \mathrm{NH}_{3}+\mathrm{H}_{2} \mathrm{O}
$$

Através das equações 12 e 13, propostas por ANTHONISEN et al (1976), pode-se determinar a concentração de amônia livre e ácido nitroso em meios aquáticos, de acordo com o pH. 
Amônia livre $\left(\frac{m g \mathrm{NH}_{3}}{L}\right)=\frac{17}{14} \times\left(\frac{N A T \times 10^{p H}}{\frac{K_{a}}{K_{w}}+10^{p H}}\right)$

Onde,

NAT = Nitrogênio amoniacal total (íon amônio + amônia livre) $(\mathrm{mg} / \mathrm{L})$

$\mathrm{K}_{\mathrm{a}}=10^{-9,24}$ (Constante de ionização da amônia no equilíbrio a $20{ }^{\circ} \mathrm{C}$ )

$\mathrm{K}_{\mathrm{w}}=0,69 \times 10^{-14} \quad$ (Constante de ionização da água a $20^{\circ} \mathrm{C}$ )

$K_{a} / K_{w}=e^{(6,344 /(273+T)}$

$\mathrm{T}=$ Temperatura em ${ }^{0} \mathrm{C}$

Ácido Nitroso Livre $\left(\frac{m g \mathrm{HNO}_{2}}{L}\right)=\frac{46}{14} \times\left(\frac{N-\mathrm{NO}_{2}^{-}\left(\frac{m g}{L}\right)}{K_{b} \times 10^{p H}}\right)$

Onde,

$K_{b}=e^{(-2300 /(273+T)}$ (Constante de ionização do nitrito no equilíbrio).

Através das equações 11 e 12 ANTHONISEN et al (1976) puderam observar que a temperatura influenciava de maneira significativa no equilíbrio entre $\mathrm{NH}_{3} / \mathrm{NH}_{4} \mathrm{e}$ $\mathrm{HNO}_{2} / \mathrm{NO}_{2}{ }^{-}$. Acréscimos na temperatura têm como conseqüência aumento na concentração de amônia livre, favorecendo assim o acúmulo de nitrito.

PHILIPS; LAANBROEK; VERSTRAETE, (2002) afirmaram que a presença do ín amônio poderia favorecer o acúmulo de nitrito, porém o efeito da amônia livre $\left(\mathrm{NH}_{3}\right)$ é mais significativo para o processo. A amônia livre é uma inibidora competitiva da atividade da enzima nitrito-oxidoredutase, que está localizada na membrana celular das bactérias oxidantes de nitrito.

A temperatura pode influenciar também 0 crescimento dos microrganismos nitrificantes. PHILIPS; LAANBROEK; VERSTRAETE (2002) afirmam que a temperatura ótima para a nitritação é maior que para a nitratação, porém para temperaturas superiores a $25{ }^{\circ} \mathrm{C}$, o crescimento específico máximo das Nitrobacter $s p$ é inferior ao das Nitrossomonas sp, favorecendo, assim, o acúmulo de nitrito. 
Outro parâmetro importante pertinente a eficiência no acúmulo de nitrito, é a concentração de oxigênio dissolvido no meio. Baixas concentrações de oxigênio dissolvido influenciam de maneira mais significativa as bactérias oxidantes de nitrito do que as que oxidam amônio (GARRIDO et al., 1996; PHILIPS; LAANBROEK; VERSTRAETE, 2002).

CIUDAD et al., 2007 demonstraram que o acúmulo de nitrito foi favorecido pela diminuição da concentração de oxigênio dissolvido no meio.

\subsubsection{PROCESSOS ALTERNATIVOS PARA A REMOÇÃO DO NITROGÊNIO}

\subsubsection{Processo SHARON (Single Reactor High Activity Ammonia Removal Over Nitrite)}

O processo SHARON foi desenvolvido na Universidade Técnica de Delft. Ele se baseia no princípio da diferença das velocidades específicas de crescimento das bactérias que oxidam o amônio e as que oxidam nitrito, associado a um tempo de detenção celular baixo. A temperatura de operação deste processo faz com que o crescimento das bactérias que oxidam nitrito seja menor, permitindo assim o descarte das mesmas do sistema de tratamento.

No processo SHARON, o reator é mantido a altas temperaturas, favorecendo assim o crescimento das bactérias que oxidam amônio, já que para altas temperaturas a velocidade específica de crescimento destas bactérias é maior do que a das bactérias oxidantes de nitrito. Assim, o descarte dos organismos que oxidam nitrito é feito de acordo com a idade do lodo, que deve ser escolhida baseada na idade mínima para manutenção dos organismos que oxidam amônia (VERSTRAETE; PHILIPS, 1998).

MULDER; VAN KEMPEN (1997) destacam que as principais vantagens do processo SHARON são os baixos custos de implantação, operação e manutenção, já que o sistema é composto apenas de um reator e o investimento em aeração é reduzido. Contudo, a manutenção da temperatura no sistema é uma dificuldade do processo.

O processo SHARON pode ser usado como pré-tratamento em estações com sistemas com limitada capacidade de aeração e de desnitrificação (VERSTRAETE; PHILIPS, 1998). 


\subsubsection{Processo ANAMMOX:}

Em 1990, o laboratório de biotecnologia em Delft reportou a descoberta de um novo processo, no qual o amônio era convertido a nitrogênio gás, tendo o nitrito como aceptor de elétrons, sendo que tal processo ocorria em condições anaeróbias. Posteriormente, tal processo recebeu a denominação de ANAMMOX (VERSTRAETE; PHILIPS, 1998).

Vale ressaltar que o processo ANAMOX necessita de uma etapa aeróbia para a remoção de nitrogênio (nitritação), ou seja, o sistema não é puramente anaeróbio.

Em síntese a reação que governa o processo pode ser visualizada através da equação 14.

$$
\mathrm{NO}_{2}^{-}+\mathrm{NH}_{4}^{+} \longrightarrow \mathrm{N}_{2}+2 \mathrm{H}_{2} \mathrm{O}
$$

O processo ANAMMOX é autotrófico, não necessitando de uma fonte adicional de carbono para o processo de desnitrificação, além disso, se o processo for precedido de uma etapa de nitrificação, com acúmulo de nitrito, somente parte da amônia necessitará ser oxidada, já que o restante será convertido a nitrogênio gás, tendo o nitrito como aceptor de elétrons. Este fato permite não só a redução da demanda de oxigênio para a oxidação do amônio como também a demanda de matéria orgânica para o processo de desnitrificação (VERSTRAETE; PHILIPS, 1998).

De acordo com FUX; SIEGRIST (2004), a relação ótima nitrito/amônio para o processo ANAMOX deve ser de 1,3, sendo esta relação teórica. Este fato faz com que o controle operacional do processo se torne difícil, pois além de se estabelecer a relação ótima, deve-se evitar que a amônia seja oxidada a nitrato.

FUX; SIEGRIST (2004) reportam que a remoção autotrófica de nitrogênio no processo ANAMMOX é feita exclusivamente por microrganismos da ordem dos Planctomicetos, contudo algumas bactérias do gênero Nitrossomonas $s p$ podem remover amônia em condições anaeróbias.

Os microrganismos responsáveis pelo processo ANAMMOX tem uma taxa de crescimento específico muito baixa (cerca de $0,0027 \mathrm{~h}^{-1}$ ), sendo que o tempo de duplicação da população destes microrganismos é de aproximadamente 11 dias. 
Este fato faz com que a produção de lodo no sistema seja baixíssima (FUX; SIEGRIST (2004).

A falta de caracterização dos organismos responsáveis pelo processo ANAMMOX fez com que o mesmo tivesse várias denominações e variaçoes, uma delas é o processo OLAND (Oxygen-limited Autotrophic Nitrification-denitrification). Neste processo uma cultura rica em microrganismos autotróficos é desenvolvida para depois ser utilizada como um biocatalisador no tratamento de efluentes ricos em nitrogênio amoniacal, sendo que, o cerne de todo o processo é o controle do oxigênio fornecido (VERSTRAETE; PHILIPS, 1998).

KUAI; VERSTRAETE (1998) desenvolveram trabalho com o intuito de estudar o processo OLAND para a remoção de nitrogênio amoniacal. Neste experimento, os principais parâmetros operacionais controlados foram $\mathrm{opH}$ e a demanda de oxigênio. Os resultados mostraram que para uma taxa de aplicação volumétrica da ordem de $0,13 \mathrm{~g}$ de N-NH${ }_{4}^{+} \cdot \mathrm{L}^{-1} \cdot \mathrm{d}^{-1}$, a eficiência na remoção de nitrogênio foi de $40 \%$. A taxa de remoção especifica de nitrogênio determinada foi de $50 \mathrm{mg} \mathrm{N} \cdot \mathrm{L}^{-1} \cdot \mathrm{d}^{-1}$.

Além da diminuição da demanda de oxigênio e fonte de carbono, o processo ANAMOX apresenta ainda como vantagem, a não produção de óxido nitroso $\left(\mathrm{N}_{2} \mathrm{O}\right)$ e dióxido de carbono $\left(\mathrm{CO}_{2}\right)$ e reduzidos custos operacionais (FUX; SIEGRIST, 2004).

O processo ANAMMOX é uma boa alternativa para o tratamento de percolado de aterro sanitário já que, os problemas decorrentes da baixa relação $\mathrm{DQO} / \mathrm{N}$ podem ser suprimidos devido principalmente ao fato de que, a demanda por matéria orgânica no processo é menor do que a necessária aos processos tradicionais de tratamento.

GANIGUÉ et al. 2007 utilizaram o processo ANAMMOX para o tratamento de lixiviado de aterro sanitário. $O$ tratamento mostrou-se bastante eficiente para altas taxas de aplicação volumétrica de amônia $\left(1-1,5 \mathrm{~kg} \mathrm{~N} \cdot \mathrm{m}^{-3} \cdot \mathrm{d}^{-1}\right)$. A porcentagem de conversão de amônia a nitrito variou entre $60-40 \%$, sendo a formação de nitrato baixíssima. A atividade das bactérias que oxidam amônia mostrou-se totalmente dependente do $\mathrm{pH}$ e da alcalinidade. $\mathrm{O}$ trabalho permitiu ainda determinar o valor médio da constante de inibição pela amônia livre $\left(\mathrm{k}_{1, F A}=605,48 \pm 87,18 \mathrm{mg} \mathrm{N}-\right.$ 
$\left.\mathrm{NH}_{3} \cdot \mathrm{L}^{-1}\right)$ bem como a constante média de inibição pelo ácido nitroso $\left(\mathrm{k}_{\mathrm{l}, \mathrm{FNA}}=0.49 \pm\right.$ $\left.0.09 \mathrm{mg} \mathrm{N}-\mathrm{HNO}_{2} \cdot \mathrm{L}^{-1}\right)$. 


\section{MATERIAIS E MÉTODOS}

A pesquisa para a avaliação da remoção biológica de nitrogênio de lixiviado de aterro sanitário pela via curta, foi conduzida em quatro etapas distintas. A opção por se conduzir a pesquisa em quatro fases não foi pré-estabelecida, ou seja, ao longo da condução do trabalho é que se pode definir as mudanças de fase e assim, dividir a pesquisa em quatro etapas. Na primeira etapa da pesquisa utilizou-se lixiviado bruto para a alimentação do sistema biológico (SBR) e nas três etapas posteriores o lixiviado utilizado na alimentação do sistema biológico (SBR) passou por um prétratamento físico. O fluxograma abaixo traz todas as etapas da pesquisa.

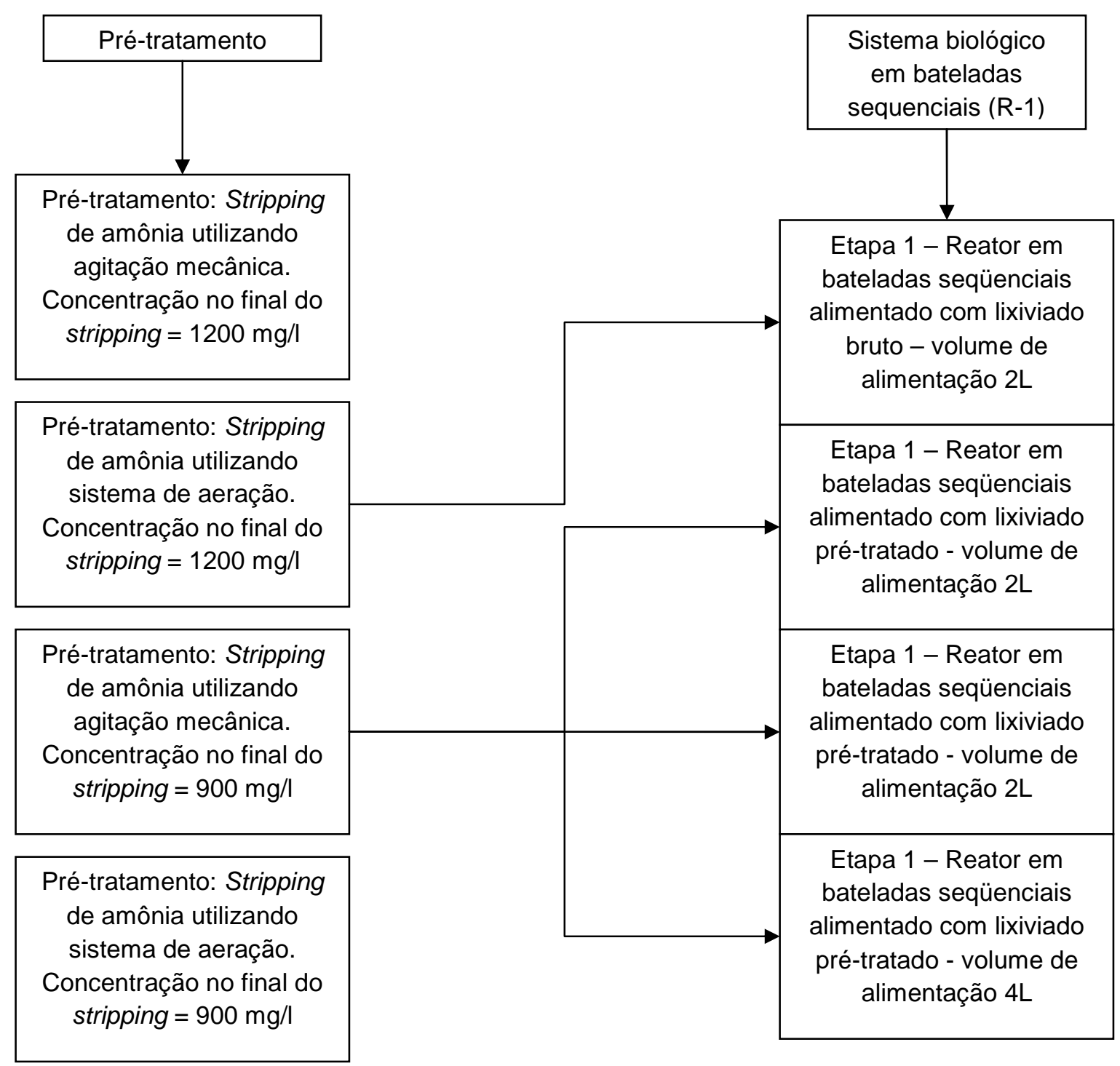


A mudança de etapas durante a condução do trabalho foi condicionada pelos resultados obtidos em cada etapa. Ao analisar os resultados da primeira fase optouse por iniciar uma nova fase com novos parâmetros operacionais já que, os resultados obtidos nesta etapa não foram satisfatórios, fato este que se repetiu na segunda fase da investigação.

A primeira etapa tinha como objetivo investigar as condições operacionais relevantes para o acúmulo de nitrito na massa líquida do reator, em um determinado período de tempo sobre condições aeróbias. Nesta etapa o efluente utilizado foi o lixiviado bruto provindo de dois aterros diferentes sendo que, os único parâmetro operacional controlado nesta fase foi o $\mathrm{pH}$ da massa líquida. A investigação foi conduzida em um reator em bateladas seqüenciais com volume útil de $20 \mathrm{~L}(\mathrm{R}-1)$ inoculado com $18 \mathrm{~L}$ de lodo biológico e alimentado com $2 \mathrm{~L}$ de lixiviado bruto contendo uma concentração de nitrogênio amoniacal em torno de $2500 \mathrm{mg} \mathrm{N} / \mathrm{L}$.

De acordo com os resultados obtidos na primeira fase da investigação, os quais não foram satisfatórios, optou-se por fazer um pré-tratamento físico que tinha por objetivo, a diminuição da concentração de nitrogênio amoniacal do lixiviado a valores próximos a $1200 \mathrm{mg} \mathrm{N} / \mathrm{L}$. O tratamento físico utilizado para a redução da concentração de nitrogênio amoniacal, foi o "stripping" de amônia. Assim, o sistema R-1 passou a ser alimentado com lixiviado pré-tratado, sendo que nesta fase procurou-se novamente avaliar a inibição da nitratação, ou seja, o acúmulo de nitrito. Como na fase anterior, nesta etapa o único parâmetro operacional controlado foi o $\mathrm{pH}$. Vale salientar que o controle do pH (adição de alcalinizante), tanto na primeira quanto na segunda etapa foi necessário para manter o $\mathrm{pH}$ da massa líquida acima ou igual a 8,3 já que, segundo literatura, a inibição da nitratação pode ser favorecida quando o pH da massa líquida for mantido acima deste valor.

Por fim, terminada a segunda etapa, partiu-se para a terceira etapa da investigação pois, os resultados desta fase foram novamente insatisfatórios. Nesta fase também optou-se por executar um pré-tratamento físico para o lixiviado bruto ("stripping" de amônia) contudo, o intuito deste pré-tratamento foi a diminuição da concentração do nitrogênio amoniacal a valores da ordem de $900 \mathrm{mg} \mathrm{N} / \mathrm{L}$. Em todas as fases da pesquisa um dos principais objetivo foi avaliar as condições operacionais 
necessárias para o eficiente acúmulo de nitrito na fase aerada do processo de tratamento.

Avaliadas as três fases da investigação, o reator R-1 foi operado tomando-se como base as condições operacionais obtidas na terceira fase da investigação, ou seja, o mesmo passou a ser alimentado com lixiviado pré-tratado contendo uma concentração de nitrogênio amoniacal de aproximadamente $900 \mathrm{mg} \mathrm{N} / \mathrm{L}$. Assim o sistema R-1 passou a ser investigado como uma alternativa para a remoção biológica do nitrogênio de liquido percolado de aterro sanitário. Vale salientar que, em todas as fases da pesquisa, foi avaliada a utilização do lixiviado como fonte de carbono para o processo de desnitritação, sendo este um importante objetivo da pesquisa.

No intuito de avaliar a tratabilidade do sistema de tratamento quando sujeito a condições operacionais diferentes, optou-se por executar uma nova etapa de tratamento (fase 4); nesta fase o reator $R-1$ foi alimentado com $4 \mathrm{~L}$, ao invés de $2 \mathrm{~L}$, de lixiviado de aterro pré-tratado $\left(\mathrm{N}_{-} \mathrm{NH}_{4}{ }^{+}=900 \mathrm{mg} / \mathrm{L}\right)$, ou seja, a fração de alimentação do sistema passou de $10 \%$ para $20 \%$ do volume do reator.

A duração das etapas do ciclo de tratamento (enchimento, anóxica, aerada, repouso e descarte) do sistema R-1 foi ajustada durante a pesquisa com o objetivo de alcançar melhores eficiências para o processo de tratamento. 


\subsection{Percolado de aterro sanitário}

Para a condução da pesquisa foi utilizado lixiviado provindo de dois aterros sanitários diferentes.

\subsubsection{ATERRO BANDEIRANTES}

O aterro Bandeirantes fica localizado no $\mathrm{Km} 26$ da rodovia dos Bandeirantes/SP. A operação deste aterro foi iniciada em 1979, sendo que o mesmo já recebeu mais de 23 milhões de toneladas de lixo desde o inicio de sua operação. No final de sua operação, que se deu em março de 2007, o volume de lixo recebido diariamente pelo aterro bandeirantes era de 7 mil toneladas por dia; deste montante $60 \%$ eram de resíduos orgânicos, produzindo uma vazão de lixiviado em torno de $1500 \mathrm{~m}^{3} /$ dia. $\mathrm{Na}$ figura 8 é apresentada uma foto aérea da área onde está localizado o aterro Bandeirantes.

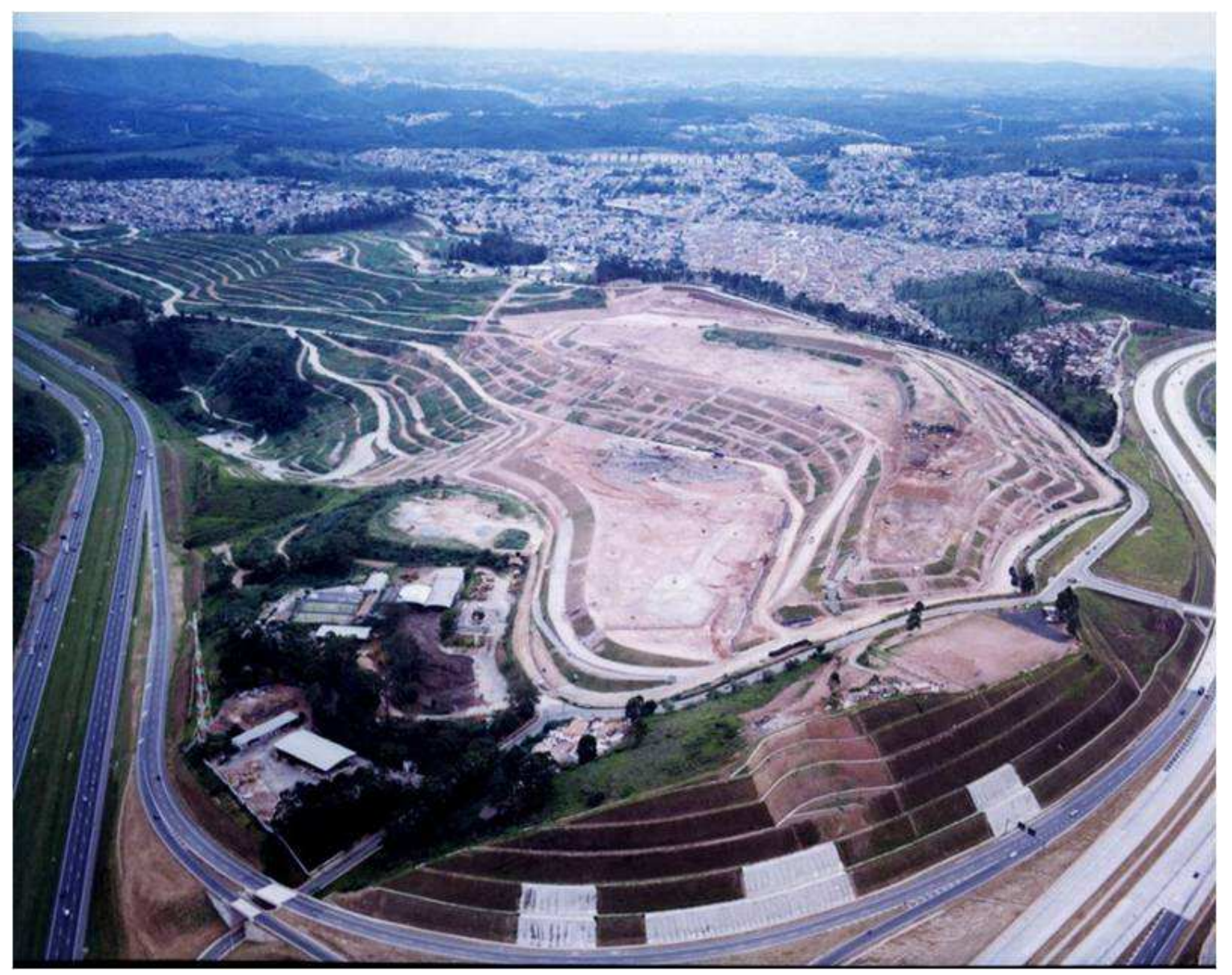

Figura 8 - Vista aérea do aterro Bandeirantes. Fonte: MELLIS, 2004. 


\subsubsection{ATERRO SÃo JOÃo}

O aterro São João fica localizado no Km 33 Estrada de Sapopemba/SP. A operação deste aterro foi iniciada em 1992, sendo que o mesmo já recebeu mais de 27,9 milhões de toneladas de lixo desde o inicio de sua operação. $O$ final da operação deste aterro se deu em Outubro de 2007 sendo que, o volume de lixo depositado diariamente no aterro São João, neste período, foi de 7 mil toneladas diárias. A vazão de lixiviado produzido durante os últimos meses de funcionamento do aterro ultrapassou $1800 \mathrm{~m}^{3} /$ dia.

Como as etapas iniciais ( 1 e 2 ) da pesquisa tinham como objetivo somente avaliar as condições ideais para uma eficiente remoção de nitrogênio (nitritação/desnitritação), foram utilizados, na alimentação do sistema R-1, lixiviados provindos dos dois aterros sanitários descritos anteriormente. $O$ objetivo não era comparar dois lixiviados com características diferentes mais sim "escolher" o que melhor se adequasse aos objetivos da pesquisa.

Já na fase 3 e 4, optou-se por alimentar o sistema R-1 com lixiviado proveniente apenas do aterro Bandeirantes. A Opção pelo aterro Bandeirantes foi devido ao fato do mesmo possuir características mais compatíveis (aterro "velho") com o objetivo da pesquisa. O cronograma simplificado da alimentação do sistema R-1 durante as etapas da pesquisa pode ser visualizado na tabela 4.

Tabela 4 - Cronograma de alimentação do sistema R-1 de acordo com o lixiviado utilizado

\begin{tabular}{|c|c|c|}
\hline Fase da Pesquisa & Ciclo & $\begin{array}{l}\text { Aterro gerador do lixiviado utilizado na alimentação do sistema } \\
\qquad \mathrm{R}-1\end{array}$ \\
\hline \multirow{3}{*}{$1^{\mathrm{a}}$} & 1 & Aterro São João \\
\hline & 2 & Aterro Bandeirantes \\
\hline & 3 & Aterro Bandeirantes \\
\hline \multirow{5}{*}{$2^{\mathrm{a}}$} & 1 & Aterro São João \\
\hline & 2 & Aterro Bandeirantes \\
\hline & 3 & Aterro Bandeirantes \\
\hline & 4 & Aterro São João \\
\hline & 5 & Aterro São João \\
\hline $3^{a}$ & Todos & Aterro Bandeirantes \\
\hline $4^{\mathrm{a}}$ & Todos & Aterro Bandeirantes \\
\hline
\end{tabular}




\subsection{INÓCULO}

O inóculo utilizado para a partida do sistema R-1 era proveniente da linha de retorno do decantador secundário de um sistema de lodos ativados integrante da estação de tratamento de esgotos domésticos de Barueri (ETE-Barueri). A ETE Barueri está em operação desde 1988 e tem capacidade para tratar até 9,5 mil litros de esgoto por minuto, sendo sua vazão de tratamento atual em torno de $7 \mathrm{mil} \mathrm{L} / \mathrm{s}$. O processo de tratamento da ETE Barueri é composto por lodos ativados convencionais com nível de tratamento secundário.

\subsection{Pré-tratamento físico do lixiviado de aterRo SANITÁRIO}

Como relatado anteriormente, nas etapas 2, 3 e 4 da pesquisa, o lixiviado foi submetido a um processo físico no sentido de se reduzir a concentração de nitrogênio amoniacal presente no mesmo. Para isto, utilizou-se o stripping de amônia que se deu em dois sistemas diferentes. O primeiro sistema era composto de uma simples agitação mecânica e o segundo constituído de um sistema de aeração.

\subsubsection{Pré-tratamento do lixiviado POR "StRIPPING" DE aMÔNIA COM AGITAÇÃO MECÂNICA}

Para esta etapa do sistema de tratamento foi utilizado um reator em acrílico (R-2) com dimensões internas de $25 \times 25 \times 40 \mathrm{~cm}$ mantido sobre agitação constante, favorecendo assim o "stripping" de amônia. O volume de lixiviado utilizado em cada ciclo de tratamento era de 20L. A agitação era provida por um agitador mecânico de palhetas simples marca Fuzzylogie, modelo CAT R100C, sendo que, a velocidade de rotação do sistema era mantida em aproximadamente $250 \mathrm{rpm}$. O "stripping" de amônia era mantido até que a concentração de nitrogênio amoniacal atingisse a concentração desejada, ou seja, o tempo de "stripping" era condicionado ao tempo decorrido para que a concentração de nitrogênio amoniacal do lixiviado atingisse um valor pré-estabelecido ( $1200 \mathrm{mg} / \mathrm{L}$ na fase 2 e $900 \mathrm{mg} / \mathrm{L}$ nas fases 3 e 4). A figura 9 traz um esquema do sistema R-2.

Não houve controle de $\mathrm{pH}$ no processo de "stripping", ou seja, o pH da massa líquida era o do próprio lixiviado. $\mathrm{O} \mathrm{pH}$ médio bem como outros parâmetros físico-químicos do lixiviado bruto serão apresentados no item resultados. 


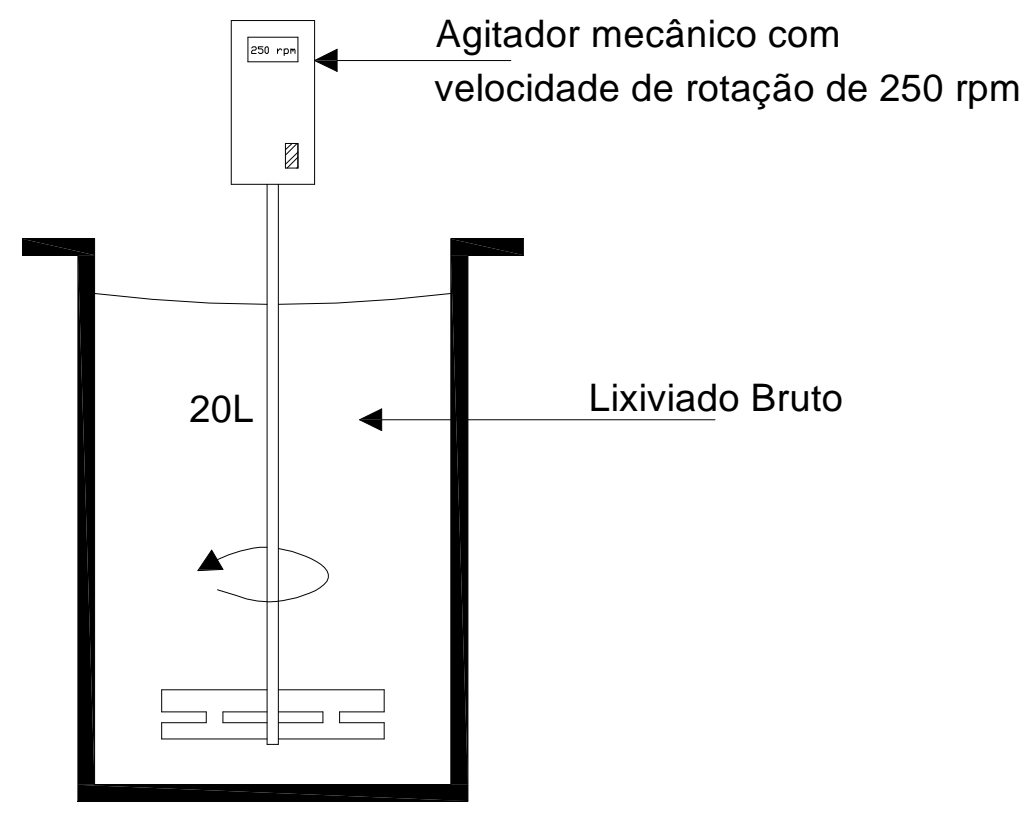

Figura 9 - Desenho esquemático do sistema R-2

\subsubsection{Rotina de análises}

A tabela 5 apresenta a seqüência de amostragem e os métodos analíticos realizados durante o "stripping" de amônia utilizando-se o sistema R-2, de acordo com o Standard Methods (APHA; AWWA; WEF, 1998).

Tabela 5 - Freqüência de amostragem e métodos analíticos dos ciclos de "stripping" para o sistema R-2

\begin{tabular}{|c|c|c|c|}
\hline Parâmetro & Fase do Ciclo & Freqüência & Método Utilizado \\
\hline DQO & $\begin{array}{l}\text { Durante o } \\
\text { "stripping" }\end{array}$ & $\begin{array}{c}\text { Inicio e final e a cada } 2 \\
\text { dias }\end{array}$ & Refluxo aberto \\
\hline DBO & $\begin{array}{l}\text { Durante o } \\
\text { "stripping" }\end{array}$ & $\begin{array}{l}\text { Inicio e Final do } \\
\text { Striping }\end{array}$ & $\begin{array}{l}\text { Método de } \\
\text { Winkler }\end{array}$ \\
\hline $\begin{array}{l}\text { Nitrogênio } \\
\text { Amoniacal }\end{array}$ & $\begin{array}{l}\text { Durante o } \\
\text { "stripping" }\end{array}$ & $\begin{array}{c}\text { Inicio e final e a cada } 2 \\
\text { dias }\end{array}$ & $\begin{array}{l}\text { Titulométrico } \\
\text { precedido de } \\
\text { destilação }\end{array}$ \\
\hline $\mathrm{pH}$ & $\begin{array}{l}\text { Durante o } \\
\text { "stripping" }\end{array}$ & A cada 2 dias & Eletrométrico \\
\hline Temperatura & $\begin{array}{l}\text { Durante o } \\
\text { "stripping" }\end{array}$ & Diariamente & $\begin{array}{l}\text { Termômetro de } \\
\text { mercúrio }\end{array}$ \\
\hline
\end{tabular}




\begin{tabular}{cccc}
\hline Parâmetro & Fase do Ciclo & Freqüência & Método Utilizado \\
\hline $\begin{array}{c}\text { Nitrogênio } \\
\text { Total Kjeldahl } \\
\text { (NKT) }\end{array}$ & $\begin{array}{c}\text { Durante o } \\
\text { "stripping" }\end{array}$ & $\begin{array}{c}\text { Inicio e Final do } \\
\text { Striping }\end{array}$ & $\begin{array}{c}\text { Titulométrico } \\
\text { precedido de } \\
\text { destilação e } \\
\text { digestão }\end{array}$ \\
\hline Alcalinidade & $\begin{array}{c}\text { Durante o } \\
\text { "stripping" }\end{array}$ & $\begin{array}{c}\text { Inicio e final e a cada 2 } \\
\text { dias }\end{array}$ & $\begin{array}{c}\text { Titulação } \\
\text { Potenciométrica }\end{array}$ \\
\hline Nitrito & $\begin{array}{c}\text { Durante o } \\
\text { "stripping" }\end{array}$ & $\begin{array}{c}\text { Inicio e Final do } \\
\text { Striping }\end{array}$ & Colorimétrico \\
\hline $\begin{array}{c}\text { Sólidos em } \\
\text { Suspensão } \\
\text { Totais (SST) }\end{array}$ & $\begin{array}{c}\text { Durante o } \\
\text { "stripping" }\end{array}$ & $\begin{array}{c}\text { Inicio e Final do } \\
\text { Striping }\end{array}$ & Gravimétrico \\
\hline $\begin{array}{c}\text { Sólidos em } \\
\text { Suspensão } \\
\text { Voláteis (SSV) }\end{array}$ & $\begin{array}{c}\text { Durante o } \\
\text { "stripping" }\end{array}$ & $\begin{array}{c}\text { Inicio e Final do } \\
\text { Striping }\end{array}$ & Gravimétrico \\
COT & $\begin{array}{c}\text { Durante o } \\
\text { "stripping" }\end{array}$ & $\begin{array}{c}\text { Inicio e final e a cada 2 } \\
\text { dias }\end{array}$ & Forno \\
\hline
\end{tabular}

\section{Análise de DQO}

Este trabalho teve uma particularidade importante pertinente à análise de DQO. Como o lixiviado de aterro possui uma parcela de compostos refratários, supunha-se que tais compostos não eram completamente digeridos durante o tempo habitual estabelecido ( $2 \mathrm{~h}$ ) para a análise de DQO por isso, decidiu-se executar analises de DQO do percolado com diferentes tempos de digestão ( $2 \mathrm{~h}$, 3h e $4 \mathrm{~h}$ ) para que fosse analisado se realmente havia uma digestão apenas parcial dos compostos presentes na amostra quanto a digestão era de apenas $2 \mathrm{~h}$. Os resultados demonstraram que houve uma diferença significativa na DQO de $2 \mathrm{~h}$ e $3 \mathrm{~h}$ (a DQO da amostra digerida por $3 \mathrm{~h}$ era mais elevada do que a de $2 \mathrm{~h}$ ); já entre a DQO de 3 e $4 \mathrm{~h}$ a diferença foi insignificante com isso, optou-se, durante toda a pesquisa, executar a análise de DQO com 3h de tempo de digestão.

\subsubsection{PRÉ-tRatamento do liXIVIado POR "StRIPPING" DE AMÔNIA COM SISTEMA DE AERAÇÃO}

Nesta etapa o lixiviado era submetido a um sistema de "stripping" formado por uma coluna (COL-1) mantida sobre aeração por bolhas grossas. A aeração era provida por uma bomba de aquário e controlada por um rotâmetro (marca Conault com vazão de ar máxima de 35L/h) que mantinha a vazão de ar na coluna em torno de 
30L/h. O volume de lixiviado, utilizado para o "stripping" na COL-1, foi de 10L. Assim, como o diâmetro interno da coluna é de $14 \mathrm{~cm}$, a altura da coluna de lixiviado (altura para a transferência de oxigênio) ficou em torno de $65 \mathrm{~cm}$. O "stripping" de amônia era mantido até que a concentração de nitrogênio amoniacal atingisse a concentração desejada. A figura 10 traz um esquema do sistema COL-1.

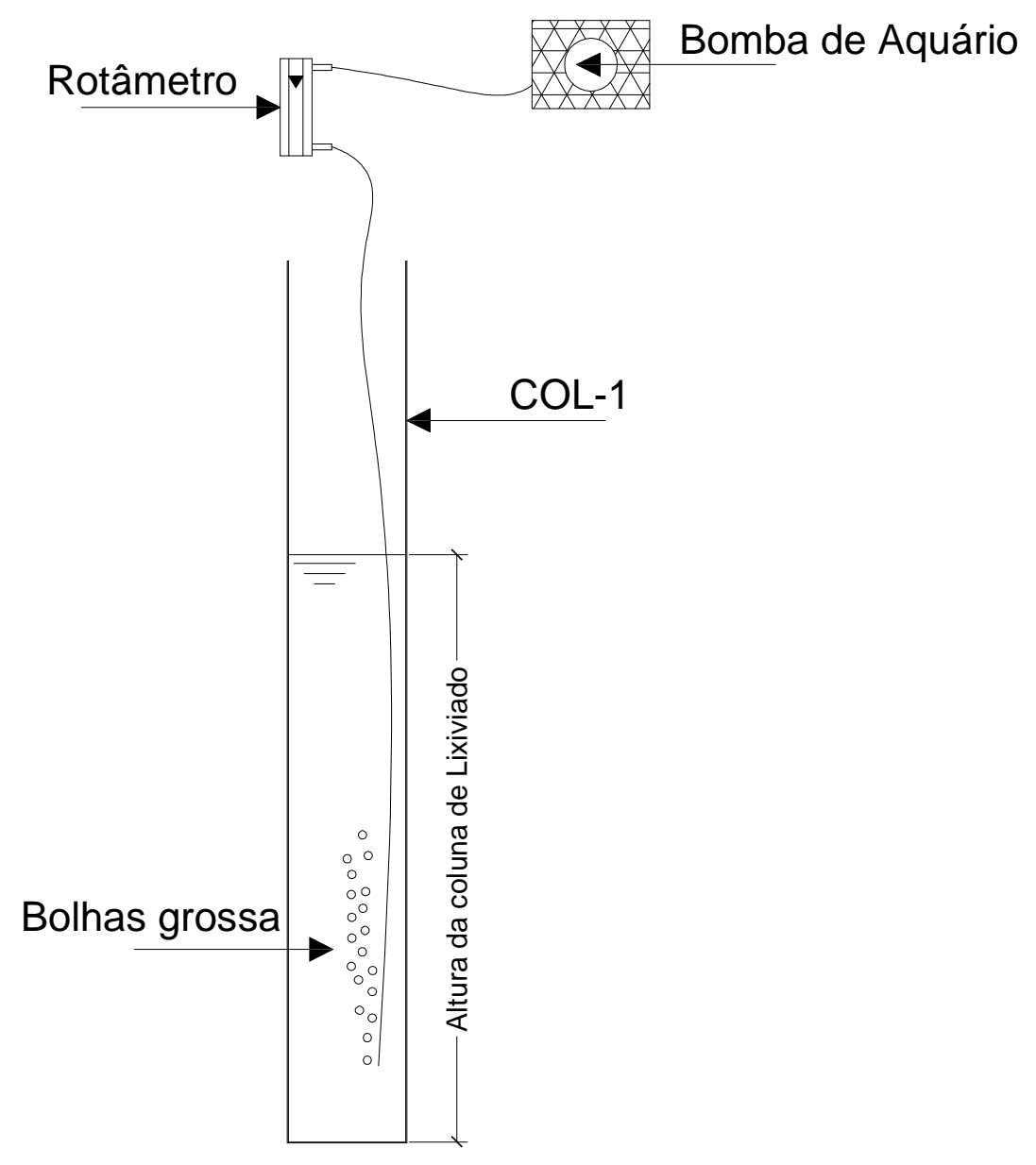

Figura 10 - Desenho esquemático do sistema COL-1

\subsubsection{Rotina de análises}

A rotina de análises para o sistema COL-1 foi o mesmo utilizado para o sistema R-2 e apresentado na tabela 5. Todas as análises foram executadas de acordo com o Standard Methods (APHA; AWWA; WEF, 1998). 
É importante ressaltar que o lixiviado utilizado para o "stripping" de amônia tanto para o sistema R-2 quanto para o sistema COL-1 era provindo do mesmo aterro, ou seja, evitou-se, para um mesmo ciclo de "stripping", o uso de um lixiviado para o sistema R-2 e outro lixiviado para o sistema COL-1.

Os procedimentos operacionais e as rotinas de análise dos sistemas R-2 e COL-1 foram semelhantes para as etapas 2,3 e 4 .

\subsection{SISTEMA EM BATELADAS SEQÜENCIAIS (R-1)}

O sistema em bateladas sequenciais R-1 tinha por objetivo avaliar a remoção de nitrogênio amoniacal de lixiviado através da via curta utilizando o próprio lixiviado como fonte de carbono para a etapa de desnitritação.

\subsubsection{ETAPA O1 - UTILIZAÇÃO DO LIXIVIADO BRUTO PARA ALIMENTAÇÃO DO SISTEMA}

\subsubsection{Partida do sistema}

Antes de se iniciarem os ciclos de tratamento o sistema R-1 foi inoculado com $18 \mathrm{~L}$ de lodo biológico e alimentado com $2 \mathrm{~L}$ de lixiviado bruto conforme especificado na tabela 4. O lodo utilizado era provindo de um sistema biológico com baixa eficiência na remoção de nitrogênio amoniacal, ou seja, não estava nitrificando. Na partida é que foi determinado que a etapa aeróbia terminaria quando a concentração de nitrogênio amoniacal no reator se aproximasse de $0 \mathrm{mg} \mathrm{N}-\mathrm{NH}_{4} / \mathrm{L}$.

\subsubsection{Aparato experimental}

A figura 11 apresenta um desenho esquemático do aparato experimental do sistema $\mathrm{R}-1$, utilizado na condução da primeira fase da pesquisa. 


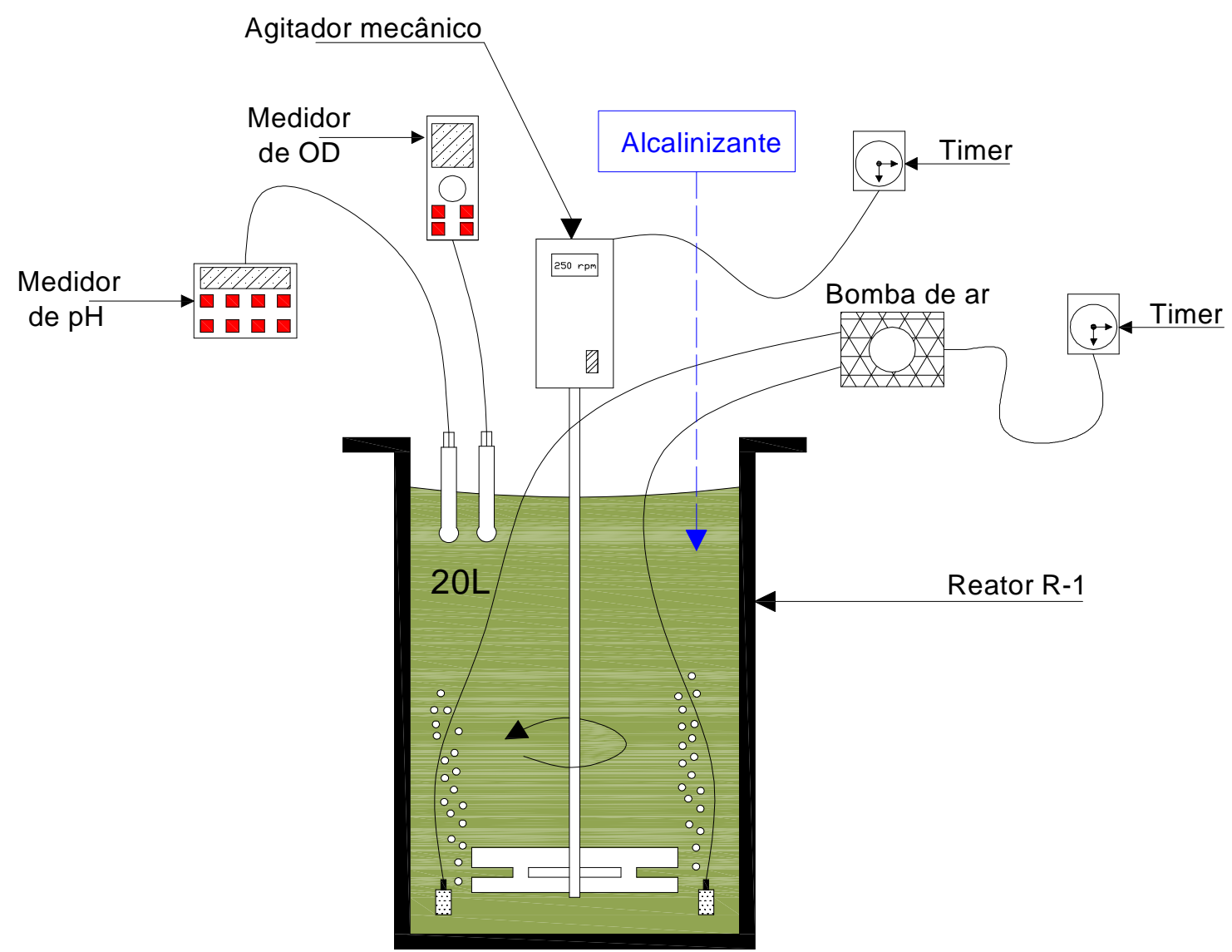

Figura 11 - Desenho esquemático do aparato experimental utilizado na primeira etapa da pesquisa

Os materiais e equipamentos utilizados na montagem do aparato experimental foram:

> Tanque de acrílico com dimensões internas de 22,5 x 22,5 x $50 \mathrm{~cm}$.

> Agitador mecânico de palheta simples marca Fuzzylogie, modelo CAT R100C.

> Medidor portátil de oxigênio dissolvido (marca YSI, modelo 55S), com um sensor de membrana que permitiu a leitura da concentração de oxigênio dissolvido (OD) na massa líquida do reator.

$>$ Controladores programáveis (timers) que permitiam a automação do sistema de acordo com os tempos das diferentes fases do ciclo de tratamento (enchimento, aeração, decantação e descarte).

> Medidor de $\mathrm{pH}$ de bancada, marca ORION, Modelo 720A, associado a um eletrodo potenciométrico, que permanecia o tempo todo imerso na massa liquida do reator.. 
> Bomba de ar similar a utilizada em aquários domésticos acoplada a pedras porosas

B Bureta manual de $50 \mathrm{ml}$, para dosagem de alcalinizante.

\subsubsection{Procedimentos de rotina}

Ao longo dos ciclos de tratamento foram desenvolvidas as seguintes atividades rotineiras:

> Calibração do sensor de $\mathrm{pH}$ utilizando padrões físico-químicos, conforme estabelecido pelo Standard Methods (APHA; AWWA; WEF, 1998).

> Limpeza e calibração do medidor de oxigênio dissolvido conforme recomendações do fabricante.

> Preparo da solução alcalinizante de hidróxido de sódio.

> Leitura do $\mathrm{pH}$ da massa líquida do reator.

> Aferição do volume útil ocupado pela massa líquida no reator.

\subsubsection{Operação do sistema}

Todos os ciclos desta etapa foram conduzidos utilizando-se o sistema R-1.

No primeiro ciclo de tratamento, após a inoculação do sistema conforme especificado no item 4.4.1.1, o sistema de aeração foi ligado juntamente com o agitador mecânico sendo que, o término da aeração se deu quando a concentração de nitrogênio amoniacal da massa não era mais detectada. Durante o período de aeração deste ciclo procurou-se manter $0 \mathrm{pH}$ da massa líquida em torno de 8,3 (exceto no ciclo 1). $\mathrm{O}$ controle do valor do $\mathrm{pH}$, mantido em torno de 8,3 para favorecer o acúmulo de nitrito, foi realizado por meio da adição manual de solução de hidróxido de sódio 1N (agente alcalinizante). Ainda na fase aerada, o ar introduzido no sistema pelas bombas de aquário (3 bombas), visava manter o valor da concentração de oxigênio dissolvido no meio abaixo de $1 \mathrm{mg} \mathrm{O}_{2} / \mathrm{L}$. Não houve controle de nenhum parâmetro operacional na fase aerada do ciclo, com exceção do $\mathrm{pH}$.

Terminada a fase aerada, foram descartados, por meio de sifonamento, $2 \mathrm{~L}$ de lixiviado "tratado". Depois do descarte, o sistema foi alimentado novamente com $2 \mathrm{~L}$ 


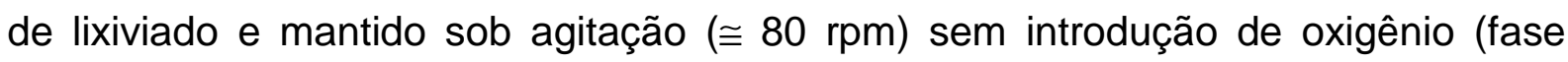
anóxica). O termino da fase anóxica se dava quando a concentração de nitrito/nitrato ${ }^{1}$, formado durante o período aerado, não era mais detectada. $O$ objetivo da fase anóxica do ciclo era avaliar a utilização do lixiviado como fonte de carbono para o processo de desnitritação/desnitrificação.

Vale lembrar que nesta fase da pesquisa a alimentação do sistema se dava de uma só vez, ou seja, os dois litros de lixiviado eram introduzidos no reator com o auxílio de uma proveta de $2 \mathrm{~L}$.

Terminada a fase anóxica, a aeração era novamente ligada (fase aerada) sendo que o término desta fase se dava conforme relatado anteriormente, terminando-se assim mais um ciclo de tratamento. Com isso, pode-se afirmar que o ciclo de tratamento iniciava-se na fase anóxica e terminava na fase aerada.

Apesar de durante os ciclos de tratamento não se utilizar mecanismos para o controle da temperatura do sistema R-1, a mesma era constantemente medida com auxílio de um termômetro manual de coluna de mercúrio. Um esquema do primeiro ciclo de tratamento, incluindo a partida do sistema R-1, pode ser visualizado através da figura 12. Vale lembrar que o esquema de operação do primeiro ciclo se repetiu para os ciclos posteriores com exceção da partida.

\footnotetext{
${ }^{1}$ Nos primeiros ciclos de tratamento formou-se, na fase aerada, tanto nitrito quanto nitrato, ou seja, não houve a inibição completa da nitratação por isso, a utilização da notação nitrito/nitrato.
} 


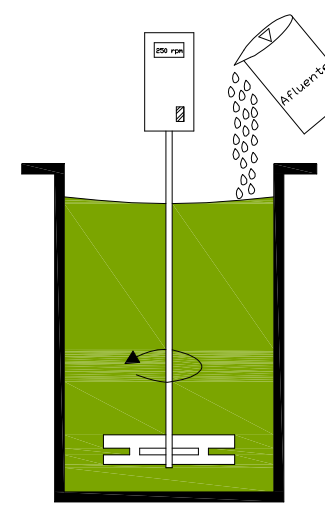

Alimentação com $2 \mathrm{~L}$ de lixiviado bruto e $18 \mathrm{~L}$ de lodo (partida)

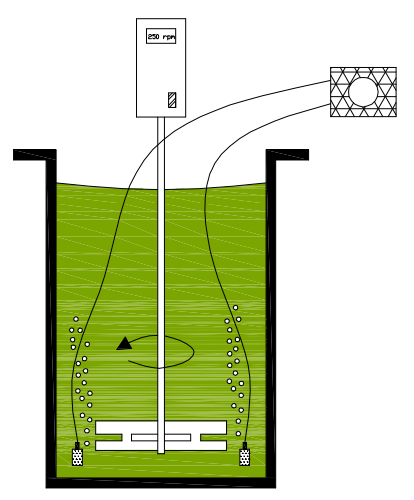

Fase Aerada com agitação (acúmulo de nitrito)

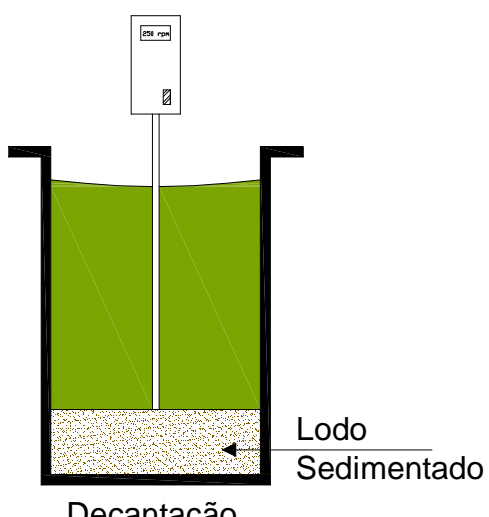

Decantação
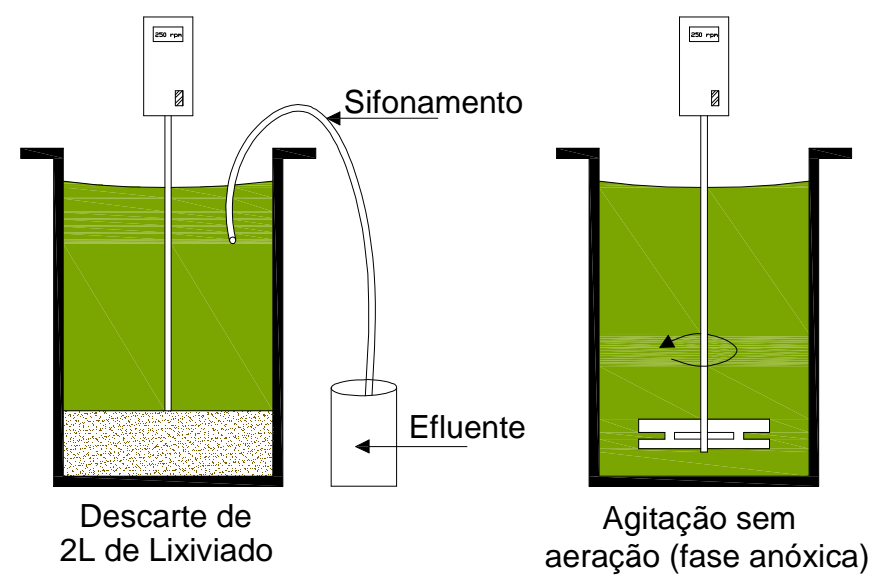

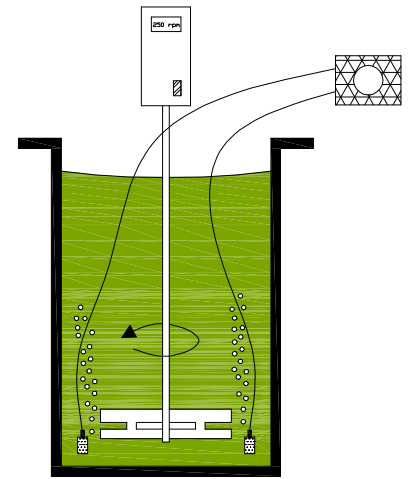

Nova aeração término do primeiro ciclo

Figura 12 - Desenho esquemático do primeiro ciclo de tratamento do sistema R-1 na primeira fase da pesquisa

Conforme apresentado na tabela 4 este modo de operação se repetiu por 3 ciclos. A interrupção do modo de operação do sistema R-1 no terceiro ciclo de tratamento, relativo à primeira fase da pesquisa, se deu baseado nos resultados obtidos nos 3 ciclos de tratamento.

\subsubsection{Rotina de análises}

A tabela 6 apresenta a seqüência de amostragem e os métodos analíticos aplicados durante a primeira fase da pesquisa, de acordo com o Standard Methods (APHA; AWWA; WEF, 1998). 
Tabela 6 - Freqüência de amostragem e métodos analíticos dos ciclos de tratamento da primeira fase da pesquisa

\begin{tabular}{|c|c|c|c|}
\hline Parâmetro & Fase do Ciclo & Freqüência & Método Utilizado \\
\hline \multirow{5}{*}{ DQO } & Inicio etapa anóxica & Sempre & \multirow{5}{*}{ Refluxo aberto } \\
\hline & $\begin{array}{l}\text { Durante etapa } \\
\text { anóxica }^{1}\end{array}$ & Amostras Pontuais $^{2}$ & \\
\hline & Final etapa anóxica & Sempre & \\
\hline & Inicio etapa aerada & Sempre & \\
\hline & Final etapa aerada & Sempre & \\
\hline \multirow{2}{*}{$\mathrm{DBO}^{3}$} & Etapa anóxica & Final da etapa & \\
\hline & Etapa aerada & Final da etapa & \\
\hline COT & Idem DQO & Idem DQO & Forno \\
\hline \multirow{6}{*}{ Nitrito } & Início etapa anóxica & Sempre & \multirow{6}{*}{ Colorimétrico } \\
\hline & Durante etapa & Após $1 \mathrm{~h}$ do inicio do & \\
\hline & anóxica & $\begin{array}{c}\text { ClClo } \\
\text { e amostras pontuais }{ }^{4}\end{array}$ & \\
\hline & Final etapa anóxica & Sempre & \\
\hline & Inicio etapa aerada & Sempre & \\
\hline & Final etapa aerada & Sempre & \\
\hline \multirow{2}{*}{$\begin{array}{l}\text { Nitrogênio } \\
\text { Amoniacal }\end{array}$} & Etapa anóxica & Inicio e final & \multirow{2}{*}{$\begin{array}{c}\text { Titulométrico } \\
\text { precedido de } \\
\text { destilação }\end{array}$} \\
\hline & Etapa aerada & Inicio e final & \\
\hline \multirow{2}{*}{ Alcalinidade } & Etapa anóxica & Inicio e final & Titulação \\
\hline & Etapa aerada & Inicio e final & Potenciométrica \\
\hline \multirow{2}{*}{$\begin{array}{l}\text { Sólidos em } \\
\text { Suspensão } \\
\text { Totais (SST) }\end{array}$} & Etapa anóxica & Uma vez durante o ciclo & Gravimétrico \\
\hline & Etapa aerada & Uma vez durante o ciclo & Gravimétrico \\
\hline \multirow{2}{*}{$\begin{array}{c}\text { Sólidos em } \\
\text { Suspensão } \\
\text { Voláteis } \\
\text { (SSV) }\end{array}$} & Etapa anóxica & Uma vez durante o ciclo & Gravimétrico \\
\hline & Etapa aerada & Uma vez durante o ciclo & Gravimétrico \\
\hline Temperatura & --------- & Permanentemente & $\begin{array}{c}\text { Termômetro de } \\
\text { Mercúrio }\end{array}$ \\
\hline $\mathrm{pH}$ & ---------- & Permanentemente & Eletrométrico \\
\hline $\begin{array}{l}\text { Oxigênio } \\
\text { Dissolvido }\end{array}$ & $\begin{array}{c}\text { Etapa } \\
\text { aerada/anóxica }\end{array}$ & Pontualmente $^{5}$ & $\begin{array}{l}\text { Eletrodo de } \\
\text { membrana }\end{array}$ \\
\hline
\end{tabular}

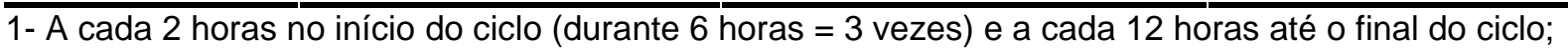

2 - Todas as vezes que eram feitas as análises de nitrito também eram executadas análises de DQO;

3 - Durante a análise foi acrescentada solução de TCMP (composto inibidor da nitrificação);

4 - Como a fase anóxica do ciclo de tratamento era muito longa optou-se por análises pontuais de nitrito durante a mesma, já que análises a cada 3 horas, por exemplo, se tornariam inviáveis e desnecessárias;

5 - Devido à inviabilidade da permanência do aparelho medidor de OD constantemente no reator, optou-se por fazer medidas pontuais do OD da massa líquida. 
Obs: as análises descritas acima foram executadas durante 20 ciclos completos referentes à terceira fase da pesquisa, bem como em todos os ciclos da etapa 1 e 2.

\subsubsection{FASE 02 - UTILIZAÇÃO DO LIXIVIADO PRÉ-TRATADO ("STRIPPING" DE AMÔNIA DO LIXIVIADO BRUTO ATÉ A CONCENTRAÇÃO DE 1200 MG-N- $\mathrm{NH}_{4} /$ L) PARA A ALIMENTAÇÃO DO SISTEMA}

Terminado os ciclos de tratamento da primeira fase da investigação, decidiu-se não mais utilizar o lixiviado bruto para a alimentação do sistema, devido principalmente às dificuldades encontradas na operação do sistema submetido a esta condição bem como o não êxito no acúmulo e nitrito; assim, decidiu-se alimentar o sistema com lixiviado pré-tratado. O pré tratamento tinha por objetivo a redução da concentração de nitrogênio amoniacal do lixiviado bruto a valores próximos a $1200 \mathrm{mg} / \mathrm{L} \mathrm{N}-\mathrm{NH}_{4}{ }^{+}$.

\subsubsection{Aparato experimental}

Nesta fase da pesquisa o reator R-1 foi novamente utilizado para avaliar a remoção biológica do nitrogênio do lixiviado de aterro. Além do reator R-1 foram utilizados os sistemas R-2 e COL-1 conforme especificado anteriormente. A figura 13 apresenta um desenho esquemático do aparato experimental do sistema $\mathrm{R}-1$, utilizado na condução da segunda fase da pesquisa. 


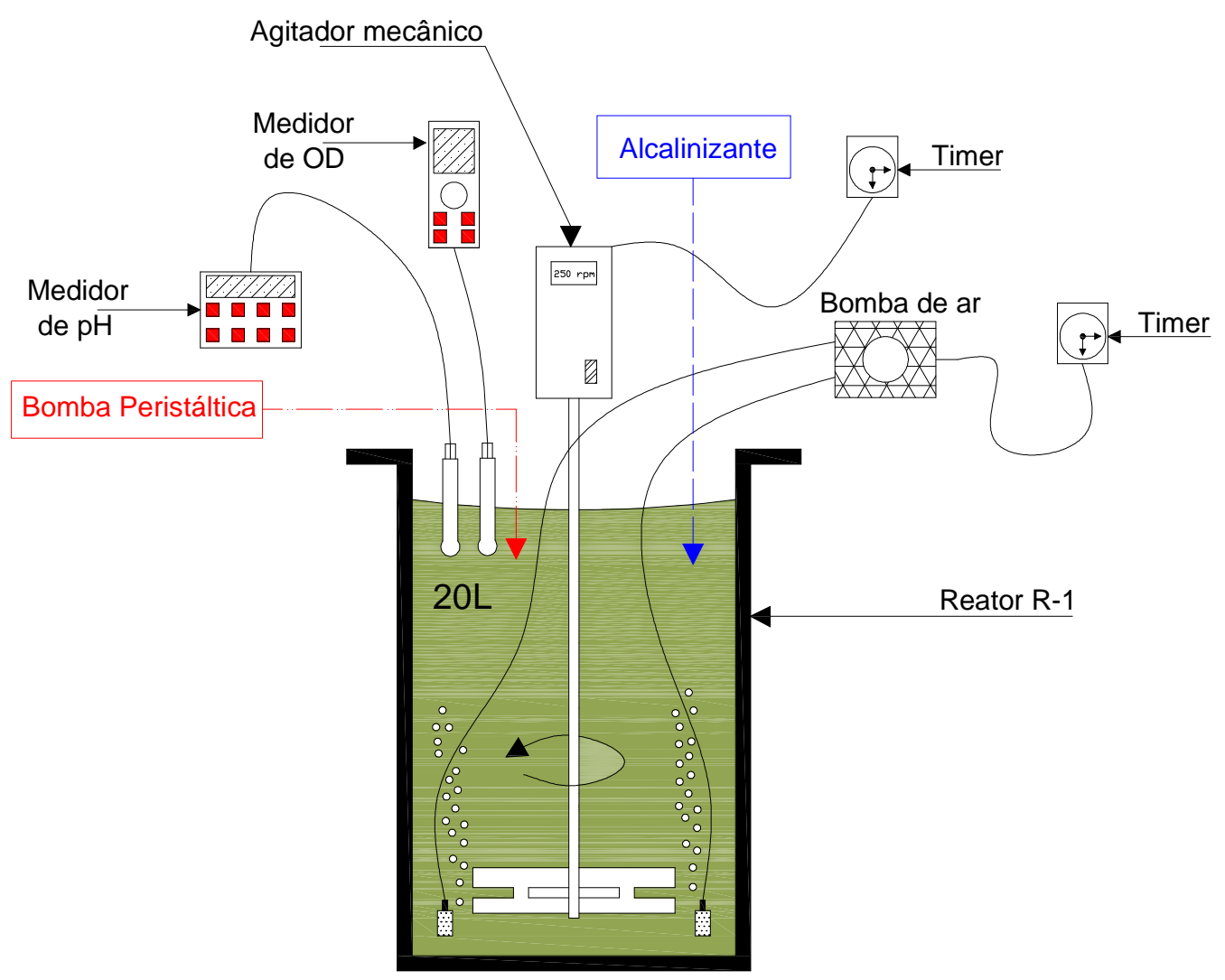

Figura 13 - Desenho esquemático do aparato experimental utilizado na segunda etapa da pesquisa

Pela figura 13 nota-se que 0 aparato experimental utilizado na segunda fase da pesquisa é o mesmo da primeira, com exceção do acréscimo de uma bomba peristáltica utilizada para a alimentação do sistema. A bomba utilizada tem as seguintes especificações:

> Bomba peristáltica multicanal, marca ProMinente, modelo CONCEPT, com vazão máxima de $1,45 \mathrm{~L} / \mathrm{h}$.

\subsubsection{Procedimentos de rotina}

Os procedimentos de rotina para esta fase foram os mesmos da primeira fase conforme especificado no item 4.4.1.3.

\subsubsection{Operação do sistema}

Nesta fase de operação optou-se por alimentar o sistema com auxílio de uma bomba peristáltica. O período estabelecido para a alimentação foi de $2 \mathrm{~h}$ com isso, levando 
em consideração um volume de alimentação de $2 \mathrm{~L}$, a vazão de trabalho da bomba durante esta fase foi ajustada para $1 \mathrm{~L} / \mathrm{h}$. O lixiviado pré-tratado era mantido em um recipiente (béquer de 2l) sobre agitação de onde era bombeado (bomba peristáltica) até o reator $\mathrm{R}-1$.

O objetivo da utilização de uma bomba peristáltica para a alimentação do sistema R-1 foi avaliar a redução do nitrito/nitrato (formado na etapa aerada do ciclo de tratamento), durante o período de alimentação.

Uma observação relevante da operação do sistema, foi que em toda a segunda fase da pesquisa, o lixiviado utilizado na alimentação do sistema era provindo do prétratamento R-2 (agitação mecânica), isso se deu pelo fato de que as características do lixiviado oriundo deste pré-tratamento eram mais "interessantes" para o tratamento biológico de remoção do nitrogênio.

Nesta fase não houve a necessidade de efetuar a partida do sistema já que, este procedimento foi executado na primeira fase da pesquisa.

O início do primeiro ciclo dessa fase se deu logo após o descarte do efluente tratado do ultimo ciclo da fase 1 (final da aeração).

Assim com exceção da alimentação do sistema, que nesta fase foi feita com auxílio de uma bomba peristáltica e do uso de lixiviado pré-tratado para alimentação do reator R-1, a operação do sistema foi igual à executada na primeira fase da pesquisa. É importante ressaltar que como na fase 1 , nesta fase houve a necessidade do controle do $\mathrm{pH}$ da massa líquida do reator $\mathrm{R}-1$ ( $\mathrm{pH}$ da massa líquida mantido próximo a 8,3). Os ciclos de tratamento pertinentes a esta fase da pesquisa podem ser visualizados através da figura 14 . 


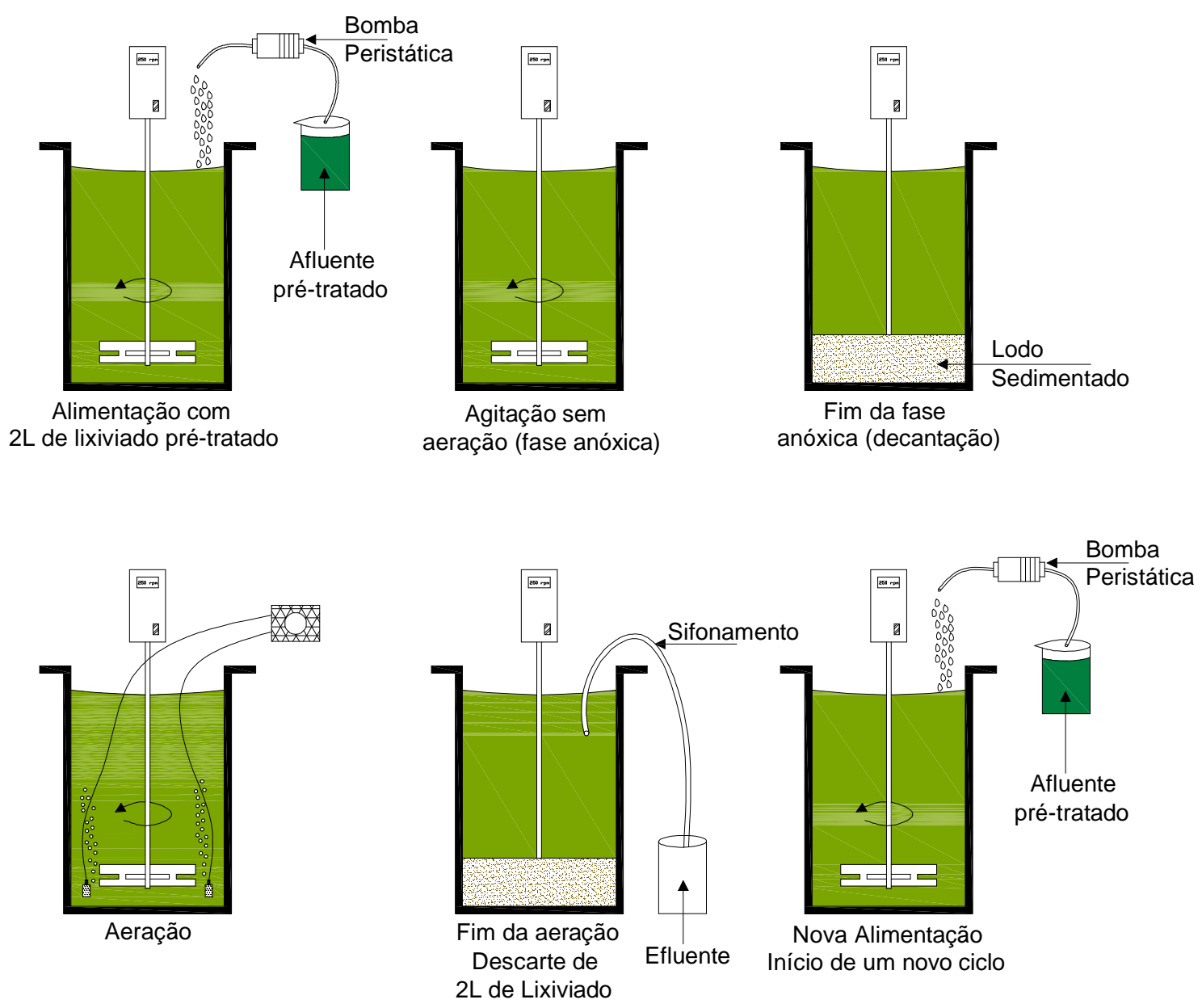

Figura 14 - Desenho esquemático da operação dos ciclos de tratamento do sistema R-1 na segunda fase da pesquisa.

\subsubsection{Rotina de análises}

A freqüência de amostragem e os métodos analíticos desta fase da investigação foram os mesmos estabelecidos para a etapa 1 (tabela 6), exceto a análise de nitrito e DQO, que eram também executados antes e depois do período de alimentação, conforme demonstrado na tabela 7. Os métodos analíticos foram todos executados de acordo com o Standard Methods (APHA; AWWA; WEF, 1998).

Tabela 7 - Freqüência de amostragem e métodos analíticos dos ciclos de tratamento da segunda fase da pesquisa

\begin{tabular}{cccc}
\hline Parâmetro & Fase do Ciclo & Freqüência & Método Utilizado \\
\hline DQO & Início da alimentação & Sempre & Refluxo aberto \\
\hline Nitrito & Final da alimentação & Sempre & Colorimétrico \\
\hline
\end{tabular}




\subsubsection{FASE O3 - UTILIZAÇÃO DO LIXIVIADO PRÉ-TRATADO ("STRIPPING" DE AMÔNIA DO LIXIVIADO BRUTO ATÉ A CONCENTRAÇÃO DE 900 MG N- $\mathrm{NH}_{3} /$ L) PARA A ALIMENTAÇÃO DO SISTEMA}

De acordo com os resultados obtidos na fase 2 optou-se por iniciar uma terceira fase da pesquisa. Nesta fase o sistema R-1 foi alimentado com lixiviado pré-tratado, sendo que este pré-tratamento era constituído novamente de um "stripping" de amônia do lixiviado (sistema R-2) até que a concentração de nitrogênio amoniacal do

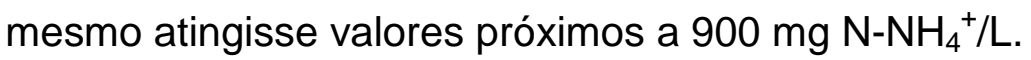

Nesta fase, abdicou-se do uso da bomba peristáltica para alimentar o sistema R-1. A alimentação voltou a ser feita de uma vez só com o auxílio de uma proveta de 2L. Esta decisão foi tomada devido ao fato de não se observar alterações consideráveis nos resultados experimentais quando se utilizou a bomba peristáltica para a alimentação do sistema já que, não houve redução significativa do nitrito/nitrato durante as duas horas de alimentação com a bomba peristáltica. Além disso, a operacionalidade do sistema foi otimizada quando o sistema passou a ser alimentado com a proveta.

Nesta fase não houve a necessidade do controle do $\mathrm{pH}$ da massa líquida do reator $\mathrm{R}-1$.

O início do primeiro ciclo dessa fase se deu logo após o descarte do efluente tratado do último ciclo da fase 2 (final da aeração).

\subsubsection{Aparato experimental}

O aparato experimental utilizado nesta fase foi o mesmo utilizado na primeira fase da pesquisa conforme especificado no item 4.4.1.2 e demonstrado na figura 11, além é claro, do aparato correspondente ao sistema R-2 (pré-tratamento)

\subsubsection{Procedimentos de rotina}

Os procedimentos de rotina para esta fase foram os mesmos da primeira fase conforme especificado no item 4.4.1.3. 


\subsubsection{Operação do sistema.}

O modo de operação do sistema $\mathrm{R}-1$ foi o mesmo utilizado na primeira fase da pesquisa, contudo, nesta fase não houve a necessidade da partida do sistema. Um esquema dos ciclos de tratamento desta fase da pesquisa pode ser visualizado através da figura 15.

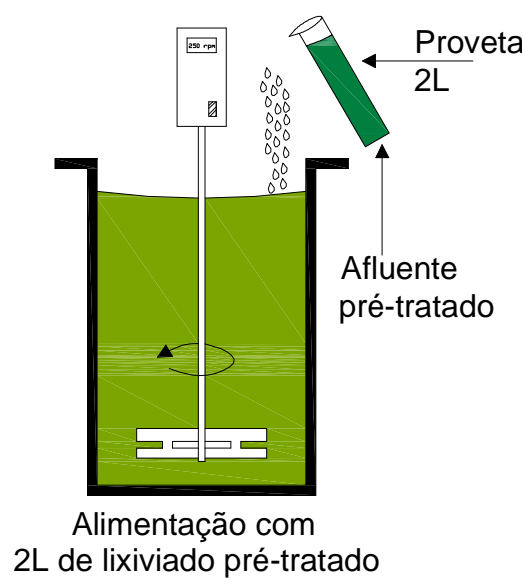

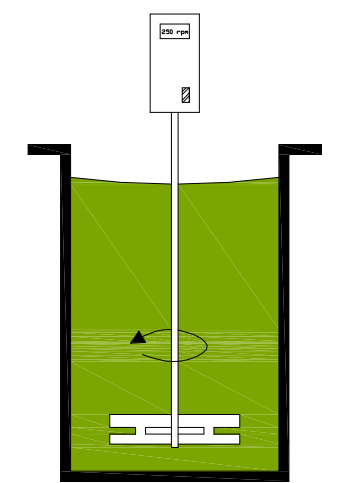

Agitação sem aeração (fase anóxica)

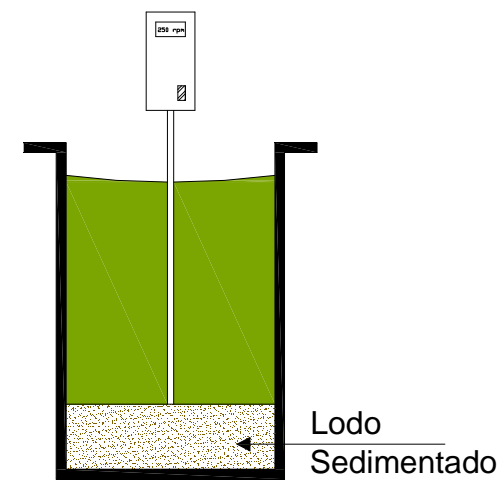

Fim da fase anóxica (decantação)
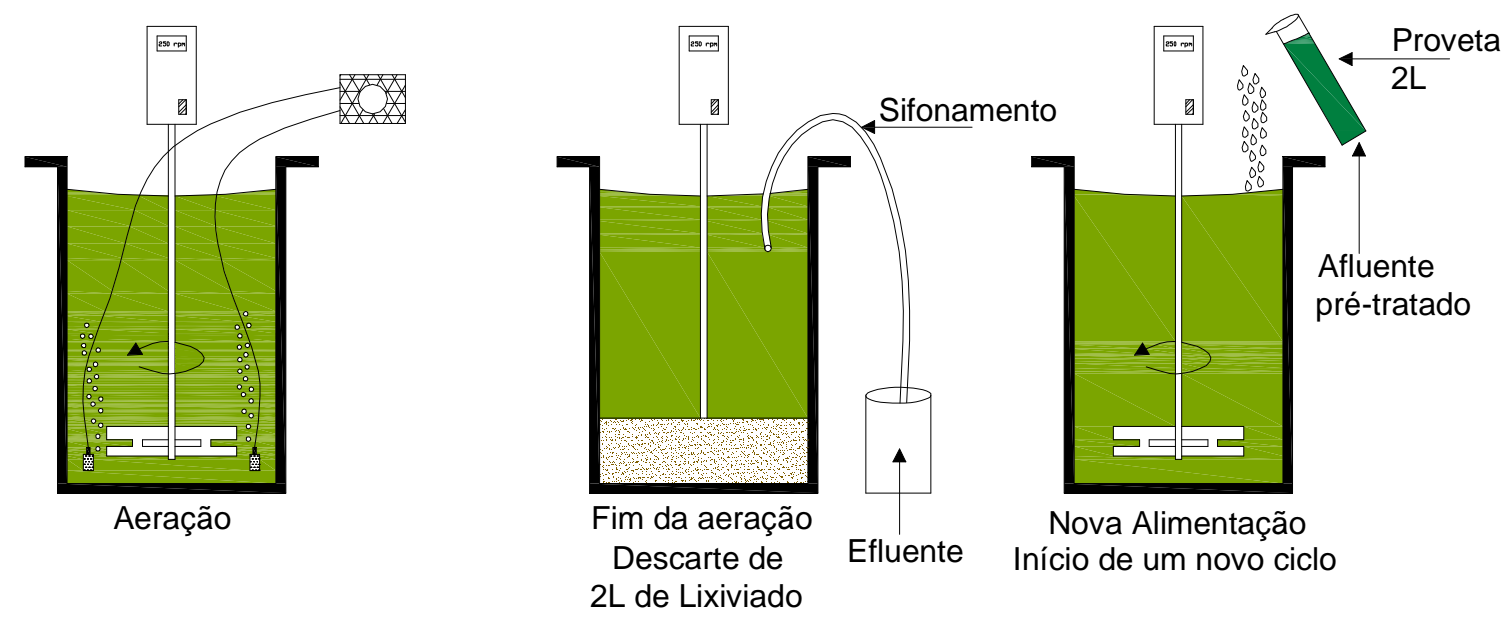

Figura 15 - Desenho esquemático da operação dos ciclos de tratamento do sistema R-1 na terceira da pesquisa.

Vale lembrar que assim como na segunda fase da pesquisa, o lixiviado utilizado para alimentar o sistema R-1 era provindo do sistema de pré-tratamento R-2. 


\subsubsection{Rotina de análises}

A freqüência de amostragem e os métodos analíticos desta fase da investigação foram os mesmos estabelecidos para a primeira fase (tabela 6). Os métodos analíticos foram todos executados de acordo com o Standard Methods (APHA; AWWA; WEF, 1998).

4.4.4 FASE 04 - UTILIZAÇÃO DO LIXIVIADO PRÉ-TRATADO ("STRIPPING" DE AMÔNIA DO LIXIVIADO BRUTO ATÉ A CONCENTRAÇÃO DE 900 MG N-NH $/$ L) PARA A ALIMENTAÇÃO DO SISTEMA E AUMENTO DA FRAÇÃO DE ALIMENTAÇÃO.

Como dito anteriormente, o objetivo desta fase da pesquisa foi avaliar o comportamento do sistema R-1 quando submetido à outra condição de operação. Para isso, o reator R-1 foi alimentado, no início da fase anóxica, com $4 \mathrm{~L}$ de lixiviado

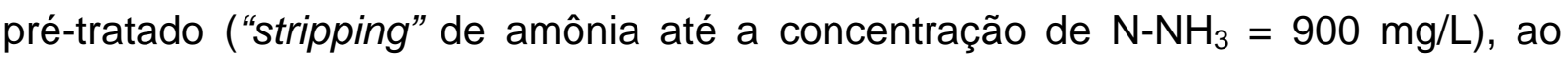
invés de $2 \mathrm{~L}$ como ocorrido na fase 1,2 , e 3.

A forma de alimentação foi a mesma utilizada na fase 1 e 3 da pesquisa, ou seja, o lixiviado era introduzido no reator R-1 de uma só vez. A alimentação mais uma vez contou com o auxílio de uma proveta de $2 \mathrm{~L}$.

É importante salientar que no final da etapa aeróbia eram descartados $4 \mathrm{~L}$ de lixiviado.

\subsubsection{Aparato experimental}

O aparato experimental utilizado nesta fase foi o mesmo utilizado na primeira fase da pesquisa conforme especificado no item 4.4.1.2 e demonstrado na figura 11, além é claro, do aparato correspondente ao sistema R-2 e COL-1 (pré-tratamento)

\subsubsection{Procedimentos de rotina}

Os procedimentos de rotina para esta fase foram os mesmos da primeira fase conforme especificado no item 4.4.1.3. 


\subsubsection{Operação do sistema.}

O modo de operação do sistema R-1 foi o mesmo utilizado na primeira fase da pesquisa, com exceção da etapa de alimentação, sendo a mesma executada de acordo com o procedimento relatado no item 4.4.4.

\subsubsection{Rotina de análises}

A freqüência de amostragem e os métodos analíticos desta fase da investigação foram os mesmos estabelecidos para a primeira fase (tabela 6). Os métodos analíticos foram todos executados de acordo com o Standard Methods (APHA; AWWA; WEF, 1998).

\subsection{Cálculo do baLANÇo de massa eXecutado dURANTE a PESQUisa (SISTEMA R-1)}

\subsubsection{INICIO DA ETAPA AERADA DO CICLO}

Massa de Namoniacal $=$ Concentração Namoniacal massa líquida $\mathrm{x}$ Volume da Massa Líquida

Massa de $\mathrm{N}^{-\mathrm{NO}_{2}}{ }^{-}=$Concentração $\mathrm{N}-\mathrm{NO}_{2}{ }^{-}$massa líquida $\times$Volume da Massa Líquida Massa de $\mathrm{N}^{-\mathrm{NO}_{3}}{ }^{-}(\mathrm{mg})$ = Concentração $\mathrm{N}-\mathrm{NO}_{3}{ }^{-}$massa líquida $\times$Volume da Massa Líquida

\subsubsection{FINAL DA ETAPA AERADA DO CICLO}

Massa de Namoniacal $=$ Concentração Namoniacal massa líquida $\mathrm{x}$ (Volume da Massa Líquida - Volume coletado para análises)

Massa de $\mathrm{N}^{-\mathrm{NO}_{2}}{ }^{-}=$Concentração $\mathrm{N}^{-N_{2}}{ }^{-}$massa líquida $\times$(Volume da Massa Líquida Volume coletado para análises)

Massa de $\mathrm{N}-\mathrm{NO}_{3}{ }^{-}=$Concentração $\mathrm{N}-\mathrm{NO}_{3}{ }^{-}$massa líquida $\times$(Volume da Massa Líquida Volume coletado para análises)

\subsubsection{INICIO DA ETAPA ANÓXICA DO CICLO}


Massa de $\mathrm{N}-\mathrm{NO}_{2}^{-}=$Massa de $\mathrm{N}^{-} \mathrm{NO}_{2}^{-}$(Final da Etapa Aeróbia) - (Volume descartado $\times$ Concentração $\mathrm{N}-\mathrm{NO}_{2}^{-}$massa líquida)

Massa de $\mathrm{N}^{-N_{3}}{ }_{3}^{-}(\mathrm{mg})=$ Massa de $\mathrm{N}^{-\mathrm{NO}_{3}}{ }^{-}$(Final da Etapa Aeróbia) - (Volume

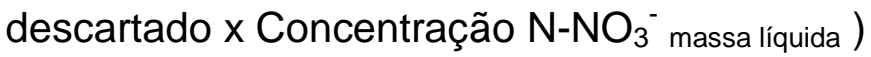

Volume descartado $=2,0$ litros (fase 1, 2 e 3) e 4,0 litros (fase 4) 


\section{RESULTADOS E DISCUSSÃO}

\section{$5.1 \quad$ LIXIVIADO DE ATERRO}

\subsubsection{ATERRO SÃo JOÃo}

Durante o período da pesquisa o aterro São João ainda recebia resíduo sólido, ou seja, os resíduos recebidos estavam em plena atividade de decomposição.

As características físico-químicas do lixiviado provindo do aterro São João podem ser vistas na tabela 8 .

Tabela 8 - Características físico-químicas do lixiviado do aterro São João

\begin{tabular}{|c|c|c|c|c|}
\hline Parâmetro & $\begin{array}{l}\mathrm{N}^{0} \text { de } \\
\text { dados }\end{array}$ & Mínimo & Máximo & Valor médio \\
\hline Demanda Química de Oxigênio (mg/L) & 4 & 7500 & 7830 & $7690 \pm 153$ \\
\hline $\begin{array}{l}\text { Demanda Bioquímica de Oxigênio } \\
\qquad(\mathrm{mg} / \mathrm{L})\end{array}$ & 4 & 1980 & 2400 & $2280 \pm 200$ \\
\hline Nitrogênio Amoniacal (mg/L) & 4 & 1940 & 2220 & $2075 \pm 121$ \\
\hline Nitrogênio Total Kjeldahl (mg/L) & 4 & 2140 & 2420 & $2240 \pm 124$ \\
\hline $\mathrm{pH}$ & 4 & 7,8 & 8,1 & 8,0 \\
\hline Temperatura & 4 & 22 & 27 & $24^{\circ} \mathrm{C}$ \\
\hline Alcalinidade $\left(\mathrm{mg} \mathrm{CaCO}_{3} / \mathrm{L}\right)$ & 4 & 8970 & 9880 & $9535 \pm 401$ \\
\hline Sólidos Totais (mg/L) & 4 & 16500 & 18860 & $17510 \pm 1084$ \\
\hline Sólidos em Suspensão Voláteis (mg/L) & 4 & 110 & 150 & $132 \pm 17$ \\
\hline
\end{tabular}




\subsubsection{ATERRO BANDEIRANTES}

O aterro Bandeirantes é considerado um aterro "velho" já que iniciou suas atividades a quase 30 anos e não recebe resíduos sólidos a mais de um ano. O lixiviado do aterro bandeirantes possui uma relativa concentração de compostos refratários 0 que dificulta sua tratabilidade quando submetido a processos de tratamento biológicos convencionais. A tabela 9 apresenta as características físico-químicas do lixiviado produzido no aterro Bandeirantes.

Tabela 9 - Características físico-químicas do lixiviado do aterro Bandeirantes

\begin{tabular}{|c|c|c|c|c|}
\hline Parâmetro & $\begin{array}{l}\mathrm{N}^{0} \text { de } \\
\text { dados }\end{array}$ & Mínimo & Máximo & Valor médio \\
\hline Demanda Química de Oxigênio (mg/L) & 20 & 6800 & 8000 & $7373 \pm 372$ \\
\hline $\begin{array}{l}\text { Demanda Bioquímica de Oxigênio } \\
\qquad(\mathrm{mg} / \mathrm{L})\end{array}$ & 20 & 1800 & 2500 & $2060 \pm 185$ \\
\hline Nitrogênio Amoniacal (mg/L) & 20 & 1950 & 2380 & $2183 \pm 93$ \\
\hline Nitrogênio Total Kjeldahl (mg/L) & 20 & 2050 & 2580 & $2343 \pm 114$ \\
\hline Carbono Orgânico Total (mg/L) & 11 & 1560 & 2230 & $1942 \pm 198$ \\
\hline $\mathrm{pH}$ & 20 & 7,9 & 8,3 & 8.1 \\
\hline Temperatura & 20 & 21 & 27 & $25^{\circ} \mathrm{C}$ \\
\hline Alcalinidade $\left(\mathrm{mg} \mathrm{CaCO}_{3} / \mathrm{L}\right)$ & 20 & 9650 & 12448 & $10720 \pm 784$ \\
\hline Sólidos Totais (mg/L) & 20 & 14350 & 21340 & $18155 \pm 1676$ \\
\hline Sólidos em Suspensão Voláteis (mg/L) & 20 & 40 & 130 & $92 \pm 22$ \\
\hline
\end{tabular}

Analisando as tabelas 8 e 9 observa-se que a concentração de matéria orgânica biodegradável (DBO) é maior no lixiviado do aterro São João apesar de a relação DBO/DQO dos dois aterros ser semelhantes. Já a concentração de nitrogênio amoniacal é maior no aterro Bandeirantes. Como já relatado, no inicio das atividades de um aterro o lixiviado apresenta uma alta concentração de matéria orgânica e uma "baixa" concentração de nitrogênio amoniacal; já após a estabilização do aterro, este quadro se inverte, ou seja, tem-se uma alta concentração de nitrogênio amoniacal e uma alta concentração de compostos refratários (menor concentração de matéria orgânica biodegradável). 


\subsection{Pré-tratamento físico do lixiviado de aterRo sanitáRIO}

\subsubsection{Pré-tratamento do lixiviado por "StRIPPING" DE aMÔNIA COM AGITAÇÃO MECÂNICA}

\subsubsection{Concentração do nitrogênio amoniacal no final do "stripping" igual a aproximadamente $1200 \mathrm{mg} / \mathrm{L}$}

Apesar de $\mathrm{o}$ controle de algumas condições ambientais (temperatura, $\mathrm{pH}$ ) influenciarem diretamente o "stripping" de amônia, nesta etapa da investigação procurou-se não fazer o controle destas condições já que, o intuito deste trabalho é que o "stripping" de amônia se "mostre" como um tratamento de nível operacional simplificado. Assim, o único parâmetro operacional controlado periodicamente foi velocidade de rotação do agitador do reator R-1 que permaneceu constante durante todo o período da investigação.

Através da figura 16 podem-se visualizar os perfis temporais das concentrações de $\mathrm{DQO}, \mathrm{N}-\mathrm{NH}_{4}{ }^{+}$e DBO dos cinco ciclos de "stripping" correspondentes a primeira fase da pesquisa. Já a tabela 10 traz as características físico-químicas do lixiviado durante os ciclos de "stripping".

Tabela 10 - Características físico-químicas do lixiviado durantes os ciclos de "stripping"

\begin{tabular}{|c|c|c|c|c|c|c|c|c|c|c|}
\hline & $\begin{array}{l}\text { Tempo } \\
\text { (d) }\end{array}$ & $\begin{array}{c}\text { Duração } \\
\text { do ciclo } \\
\text { (d) }\end{array}$ & $\begin{array}{l}\mathrm{DBO} \\
(\mathrm{mg} / \mathrm{l})\end{array}$ & $\begin{array}{l}\text { DQO } \\
(\mathrm{mg} / \mathrm{l})\end{array}$ & $\begin{array}{c}\mathrm{N}- \\
\mathrm{NH}_{3} \\
(\mathrm{mg} / \mathrm{l})\end{array}$ & $\begin{array}{c}\text { Remoção } \\
\text { de DBO } \\
(\%)\end{array}$ & $\begin{array}{l}\text { Remoção } \\
\text { DQO (\%) }\end{array}$ & $\mathrm{pH}$ & $\begin{array}{c}\text { Alcalinida } \\
\text {-de }(\mathrm{mg} \\
\left.\mathrm{CaCO}_{3} / \mathrm{L}\right)\end{array}$ & $\begin{array}{c}\text { SSV } \\
(\mathrm{mg} / \\
\mathrm{L})\end{array}$ \\
\hline
\end{tabular}

\begin{tabular}{|c|c|c|c|c|c|c|c|c|c|c|c|}
\hline \multirow{4}{*}{$\begin{array}{c}1 \\
\text { (São } \\
\text { João) }\end{array}$} & 0,0 & & 2400 & 7800 & 2200 & 39,6 & 21,0 & 8,1 & 9880 & 130 & 16780 \\
\hline & 4,0 & & & 7120 & 1870 & & & & & & \\
\hline & 8,0 & & & 6330 & 1430 & & & & & & \\
\hline & 9,0 & 10,0 & 1450 & 6160 & 1250 & & & 8,4 & 6780 & 210 & 17300 \\
\hline \multirow{4}{*}{$\begin{array}{c}2 \\
\text { (Bandei } \\
\text {-rantes) }\end{array}$} & 10,0 & & 2050 & 7150 & 2130 & 42,0 & 20,1 & 8,0 & 11230 & 110 & 18760 \\
\hline & 14,0 & & & 6720 & 1880 & & & & & & \\
\hline & 18,0 & & & 6020 & 1400 & & & & & & \\
\hline & 20,0 & 10,0 & 1190 & 5710 & 1220 & & & 8,3 & 7870 & 210 & 19350 \\
\hline \multirow{4}{*}{$\begin{array}{c}3 \\
\text { (Bandei } \\
\text {-rantes) }\end{array}$} & 21,0 & & 1940 & 6890 & 1950 & 36,6 & 20,5 & 8,2 & 11120 & 110 & 19100 \\
\hline & 25,0 & & & 6350 & 1830 & & & & & & \\
\hline & 29,0 & & & 5830 & 1450 & & & & & & \\
\hline & 31,0 & 10,0 & 1230 & 5480 & 1240 & & & 8,5 & 8210 & 190 & 19770 \\
\hline \multirow{4}{*}{$\begin{array}{c}4 \\
\text { (São } \\
\text { João) }\end{array}$} & 32,0 & & 2350 & 7640 & 2120 & 33,6 & 18,7 & 8,1 & 9750 & 150 & 17900 \\
\hline & 36,0 & & & 7180 & 1830 & & & & & & \\
\hline & 40,0 & & & 6530 & 1400 & & & & & & \\
\hline & 41,0 & 10,0 & 1560 & 6210 & 1220 & & & 8,5 & 6690 & 250 & 18550 \\
\hline
\end{tabular}




\begin{tabular}{|c|c|c|c|c|c|c|c|c|c|c|c|}
\hline Ciclo & $\begin{array}{l}\text { Tempo } \\
\text { (d) }\end{array}$ & $\begin{array}{l}\text { Duração } \\
\text { do ciclo } \\
\text { (d) }\end{array}$ & $\begin{array}{c}\mathrm{DBO}_{5}, \\
20 \\
(\mathrm{mg} / \mathrm{l})\end{array}$ & $\begin{array}{l}\text { DQO } \\
(\mathrm{mg} / \mathrm{l})\end{array}$ & $\begin{array}{c}\mathrm{N}- \\
\mathrm{NH}_{3} \\
(\mathrm{mg} / \mathrm{l})\end{array}$ & $\begin{array}{c}\text { Remoção } \\
\text { de DBO } \\
(\%)\end{array}$ & $\begin{array}{l}\text { Remoção } \\
\text { DQO (\%) }\end{array}$ & $\mathrm{pH}$ & $\begin{array}{c}\text { Alcalinida } \\
\text { de }(\mathrm{mg} \\
\left.\mathrm{CaCO}_{3} / \mathrm{L}\right)\end{array}$ & $\begin{array}{c}\text { SSV } \\
\text { (mg/ } \\
\mathrm{L})\end{array}$ & $\begin{array}{c}\mathrm{ST}(\mathrm{m} \\
\mathrm{g} / \mathrm{L})\end{array}$ \\
\hline \multirow{4}{*}{$\begin{array}{c}\mathbf{5} \\
\text { (São } \\
\text { João) }\end{array}$} & 42,0 & & 2380 & 7500 & 1940 & 35,3 & 18,4 & 8,0 & 8970 & 140 & 18860 \\
\hline & 46,0 & & & 7020 & 1750 & & & & & & \\
\hline & 50,0 & & & 6450 & 1360 & & & & & & \\
\hline & 52,0 & 10,0 & 1540 & 6120 & 1250 & & & 8,3 & 6100 & 190 & 19310 \\
\hline
\end{tabular}

Através da figura 17 pode-se observar que houve uma remoção de matéria orgânica do lixiviado, quando o mesmo foi submetido ao "stripping" de amônia, sendo este fato confirmado pela diminuição das concentrações DQO e DBO. Analisando-se a tabela 10 observa-se um aumento na concentração de sólidos (ST, SSV) após o "stripping", este fato denota para um crescimento de biomassa durante o tratamento, podendo ser esta biomassa, uma das responsáveis pela decomposição da matéria orgânica presente no lixiviado bruto. Este aumento da biomassa era visível já que, quando era feito o descarte do lixiviado após o término do "stripping" era possível visualizar a deposição (sedimentação) de sólidos no fundo do reator R-2.

Outros parâmetros também sofreram alterações significativas durante o ciclo de "stripping" de amônia como, por exemplo, o pH e a alcalinidade. A figura 18 traz a variação temporal do $\mathrm{pH}$ durante o primeiro ciclo de "stripping" e a figura 19 traz a variação temporal da alcalinidade total durante o mesmo ciclo. 


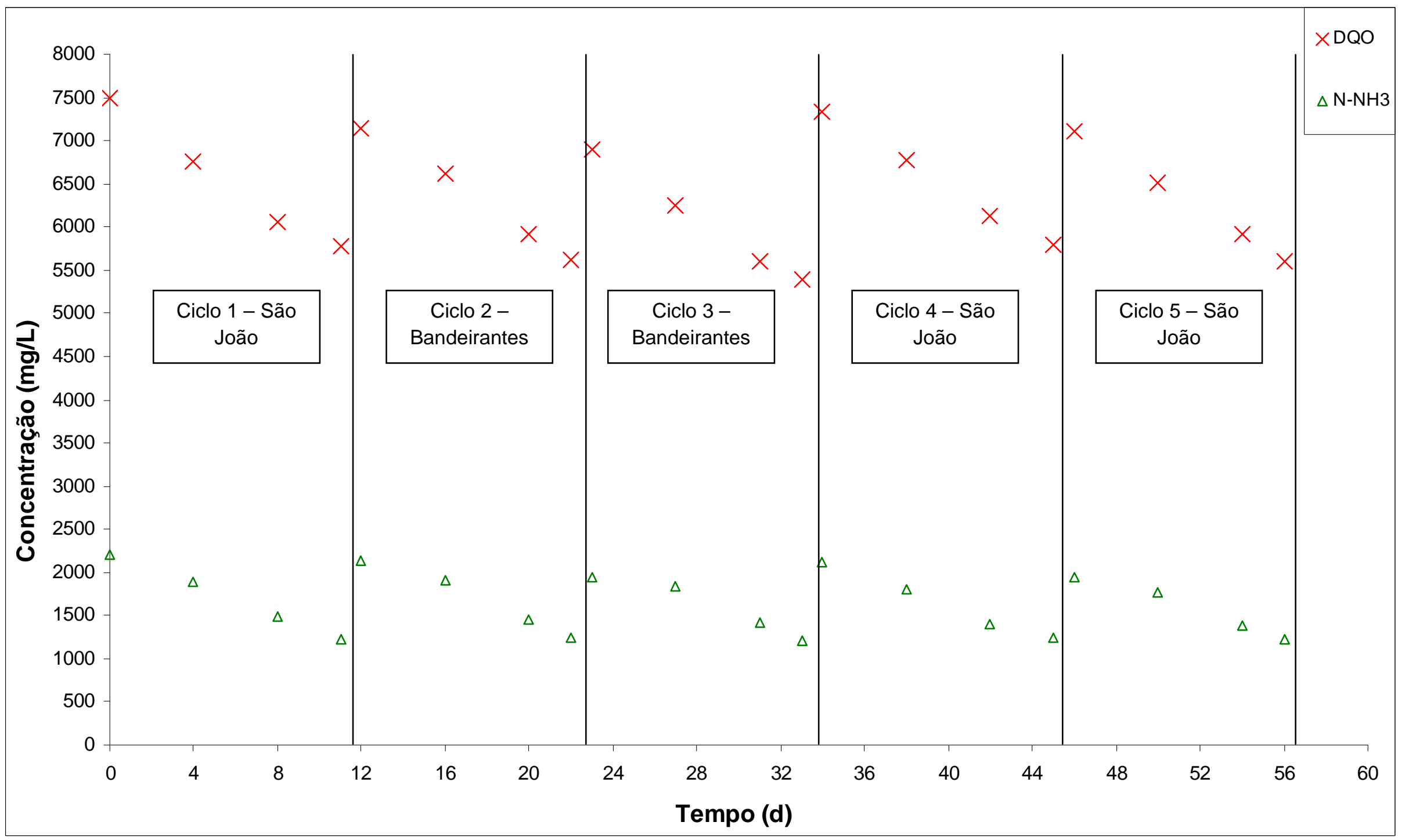

Figura 16 - Perfis temporais das concentrações de DQO e N-NH 3 durante os ciclos de "stripping" da primeira fase - Sistema R-2 


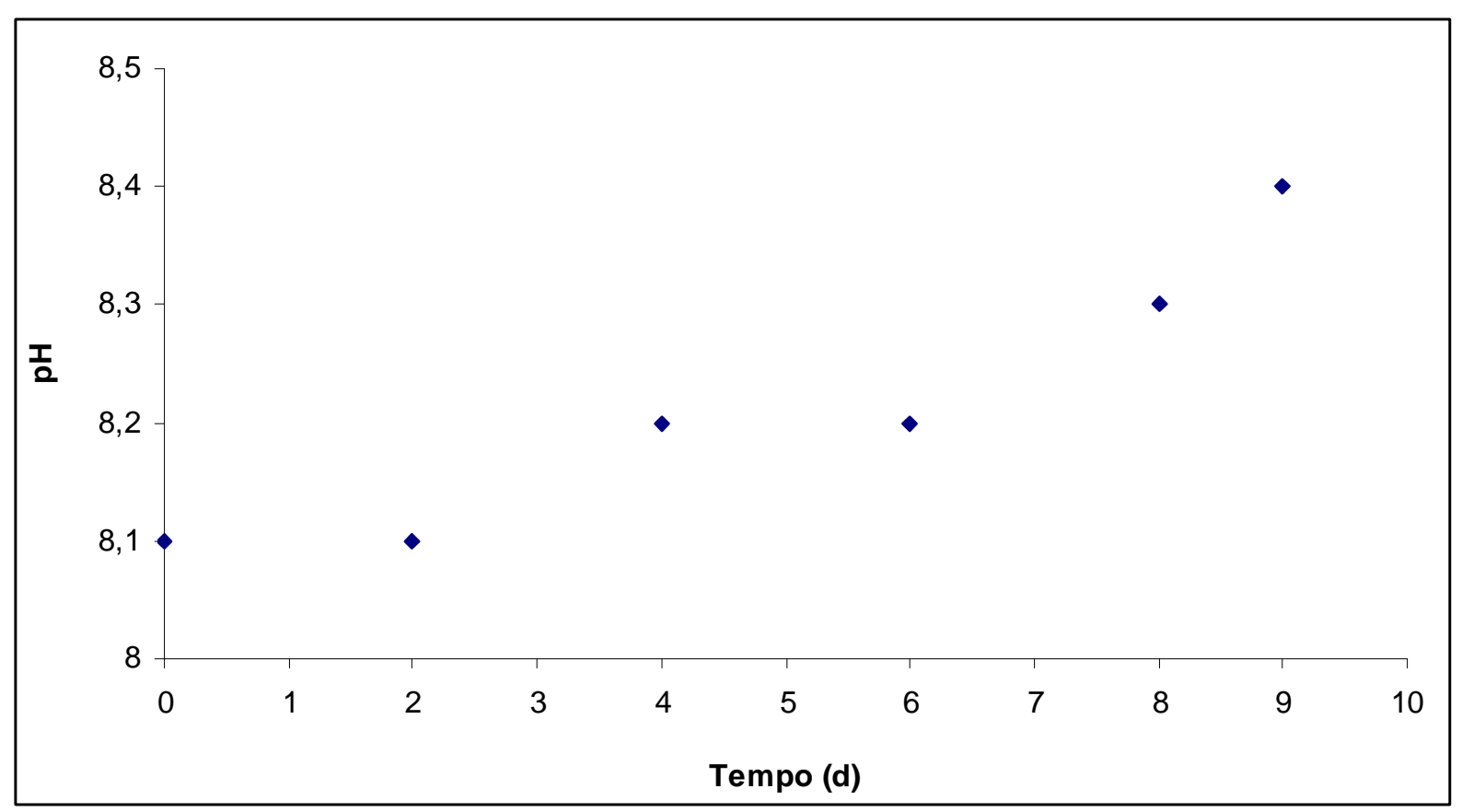

Figura 17 - Variação temporal do pH do lixiviado durante o primeiro ciclo de "stripping" (sistema R-2/Fase 1).

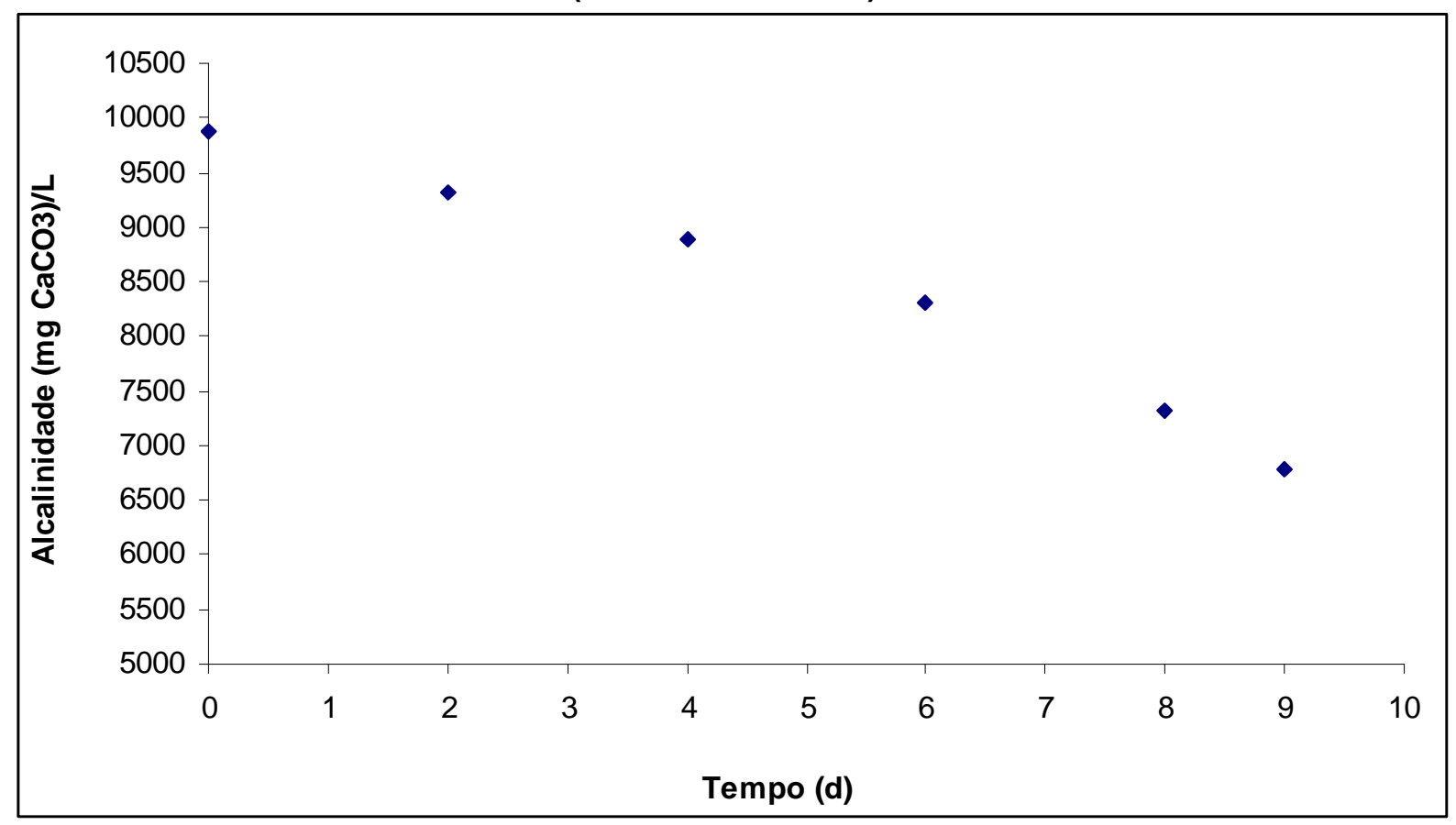

Figura 18 - - Variação temporal da alcalinidade total do lixiviado durante o primeiro ciclo de "stripping" (sistema R-2/Fase 1).

O aumento do $\mathrm{pH}$ durante o "stripping" se deu, possivelmente, pelo deslocamento do equilíbrio químico do íon amônio ao longo do ciclo já que houve uma diminuição da concentração de nitrogênio amoniacal da massa líquida do reator. 
Apesar do aumento do $\mathrm{pH}$, houve uma queda na concentração da alcalinidade durante o ciclo de "stripping". Segundo PARKES; JOLLEY; WILSON (2007) o "stripping" de amônia provoca o arraste de $\mathrm{CO}_{2}$ tendo como conseqüência a diminuição da alcalinidade total da massa líquida.

A Figura 20 demonstra a distribuição das concentrações de $\mathrm{N}-\mathrm{NH}_{3}$ durante os ciclos de "stripping" utilizando-se o lixiviado do aterro São João, já a figura 21 traz o gráfico dos valores médios das concentrações de $\mathrm{N}-\mathrm{NH}_{3}$ durante o ciclo.

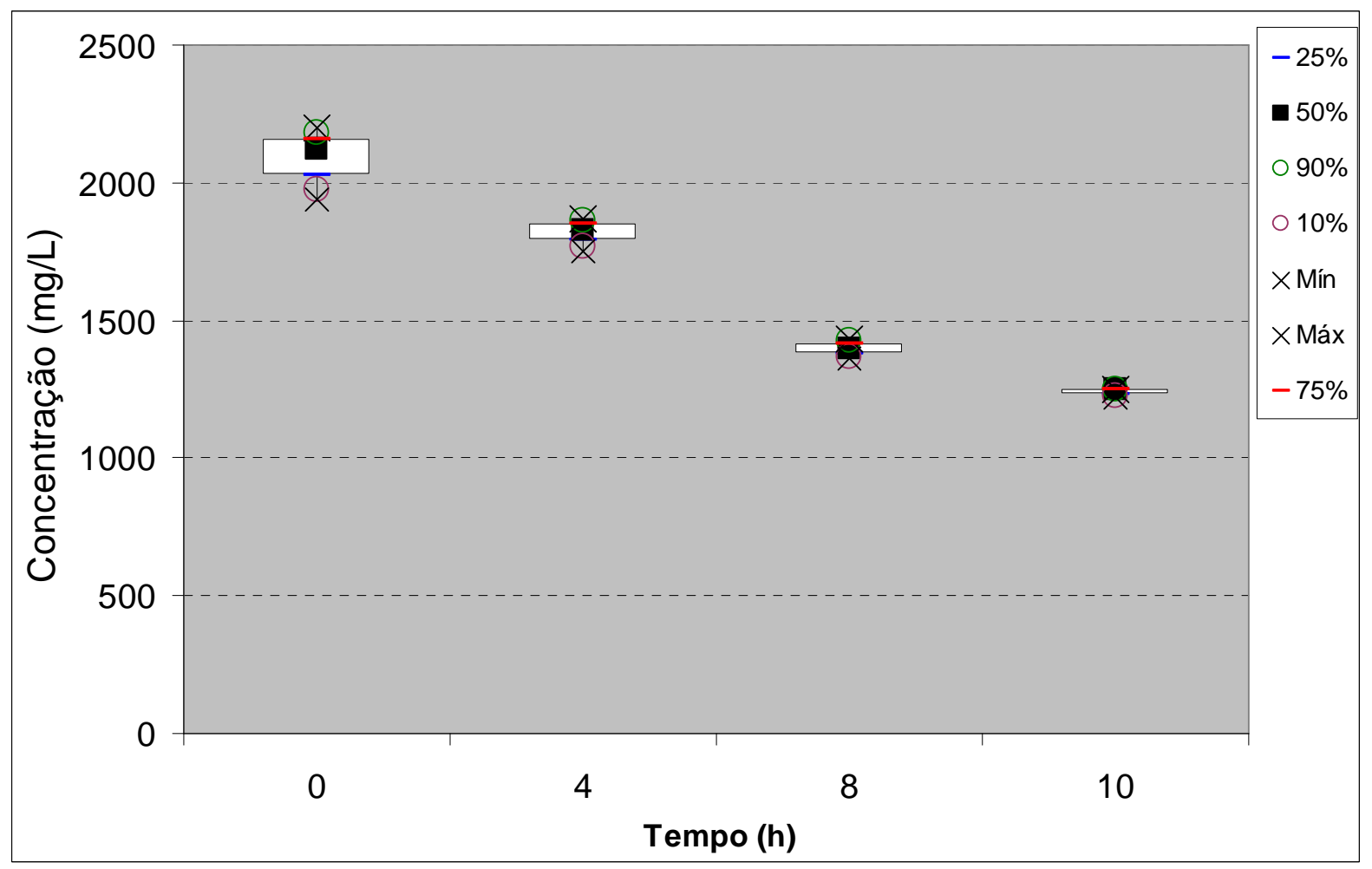

Figura 19 - Perfis das concentrações de $\mathrm{N}-\mathrm{NH}_{3}$ durante os ciclos de "stripping" do lixiviado provindo do aterro São João - concentração de $\mathrm{N}-\mathrm{NH}_{3}$ final de aproximadamente $1200 \mathrm{mg} / \mathrm{L}$. 


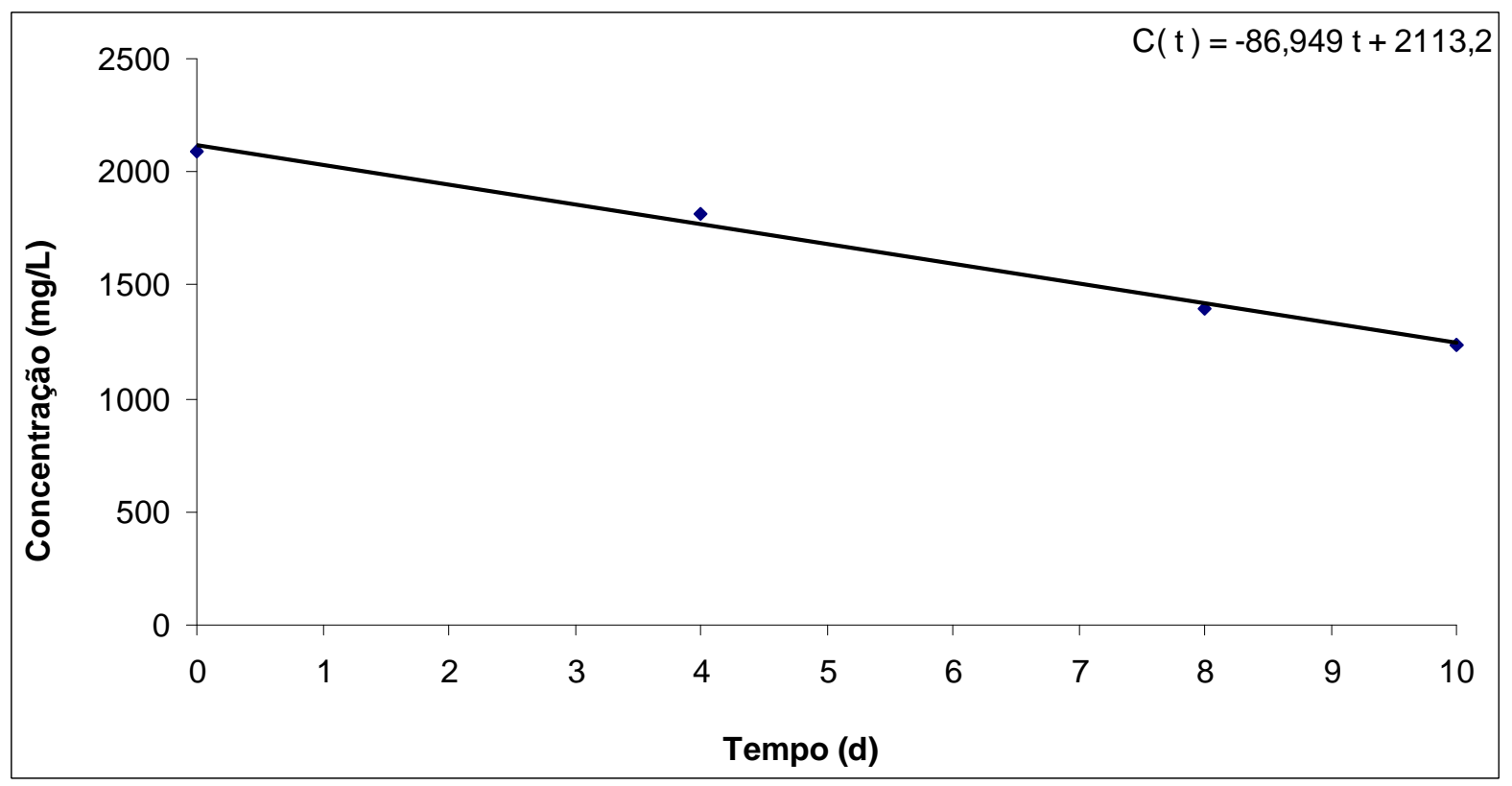

Figura 20 - Concentrações médias de $\mathrm{N}-\mathrm{NH}_{3}$ durante os ciclos 1, 4 e 5 de "Stripping" - Aterro São João.

Através da equação que representa a variação da concentração de $\mathrm{N}-\mathrm{NH}_{3}$ durante o tempo de "stripping", pode-se afirmar que a taxa média de transferência de amônia (K) durante os ciclos 1,4 e 5 foi igual a $86,95 \mathrm{mg} \mathrm{N}-\mathrm{NH}_{3} / \mathrm{L}$.dia. A figura 22 demonstra a distribuição das concentrações de $\mathrm{N}-\mathrm{NH}_{3}$ durante os ciclos de "stripping" utilizandose 0 aterro Bandeirantes e a figura 23 traz gráfico dos valores médios das concentrações de $\mathrm{N}-\mathrm{NH}_{3}$ durante o ciclo. Tanto para os ciclos utilizando lixiviado do aterro Bandeirantes quanto do aterro São João as equações cinéticas que representam o arraste de amônia durante o ciclo são de ordem zero. 


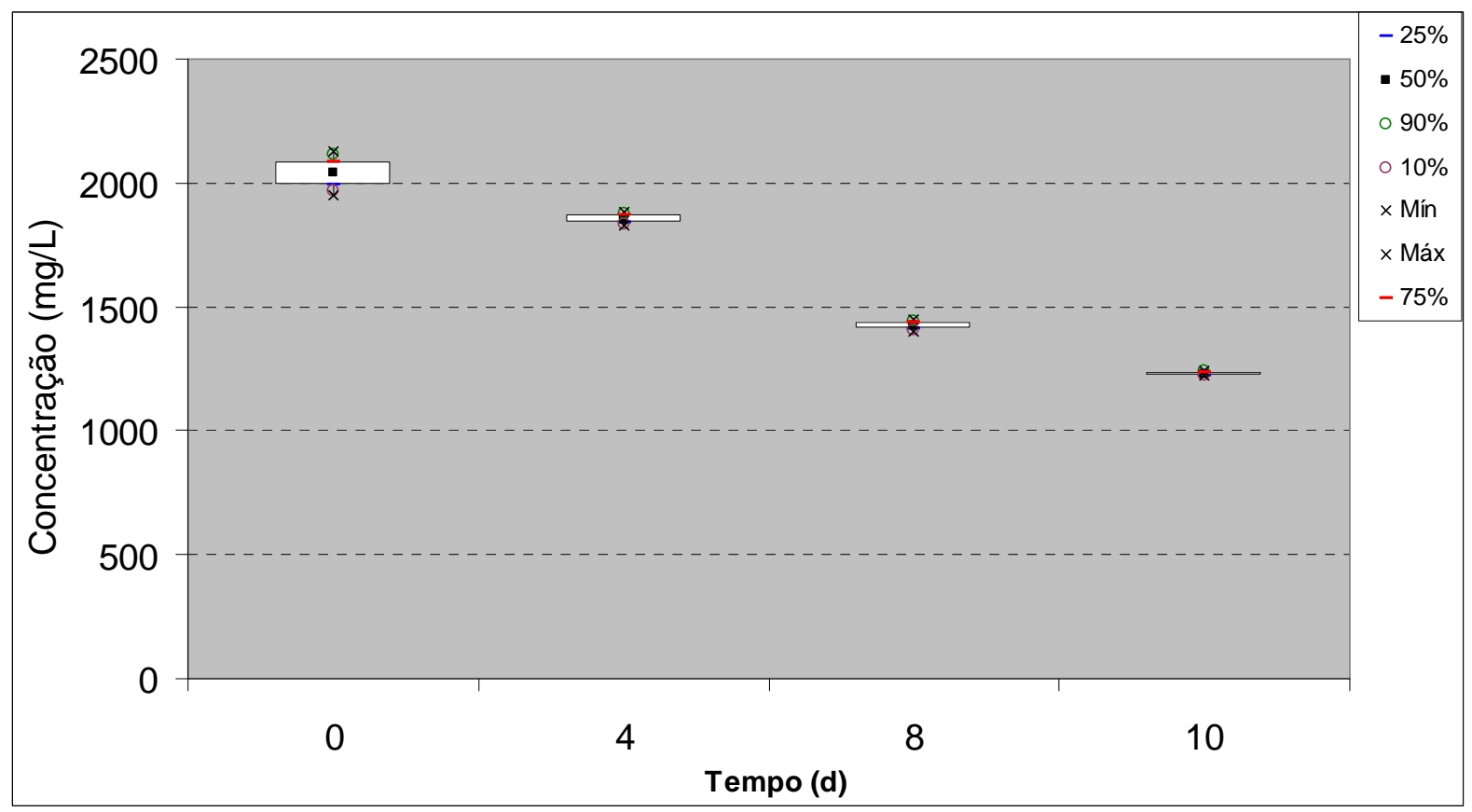

Figura 21 - Perfis das concentrações de $\mathrm{N}-\mathrm{NH}_{3}$ durante os ciclos de "stripping" do lixiviado provindo do aterro Bandeirantes - concentração de $\mathrm{N}^{-\mathrm{NH}_{3}}$ final de aproximadamente 1200 $\mathrm{mg} / \mathrm{L}$.

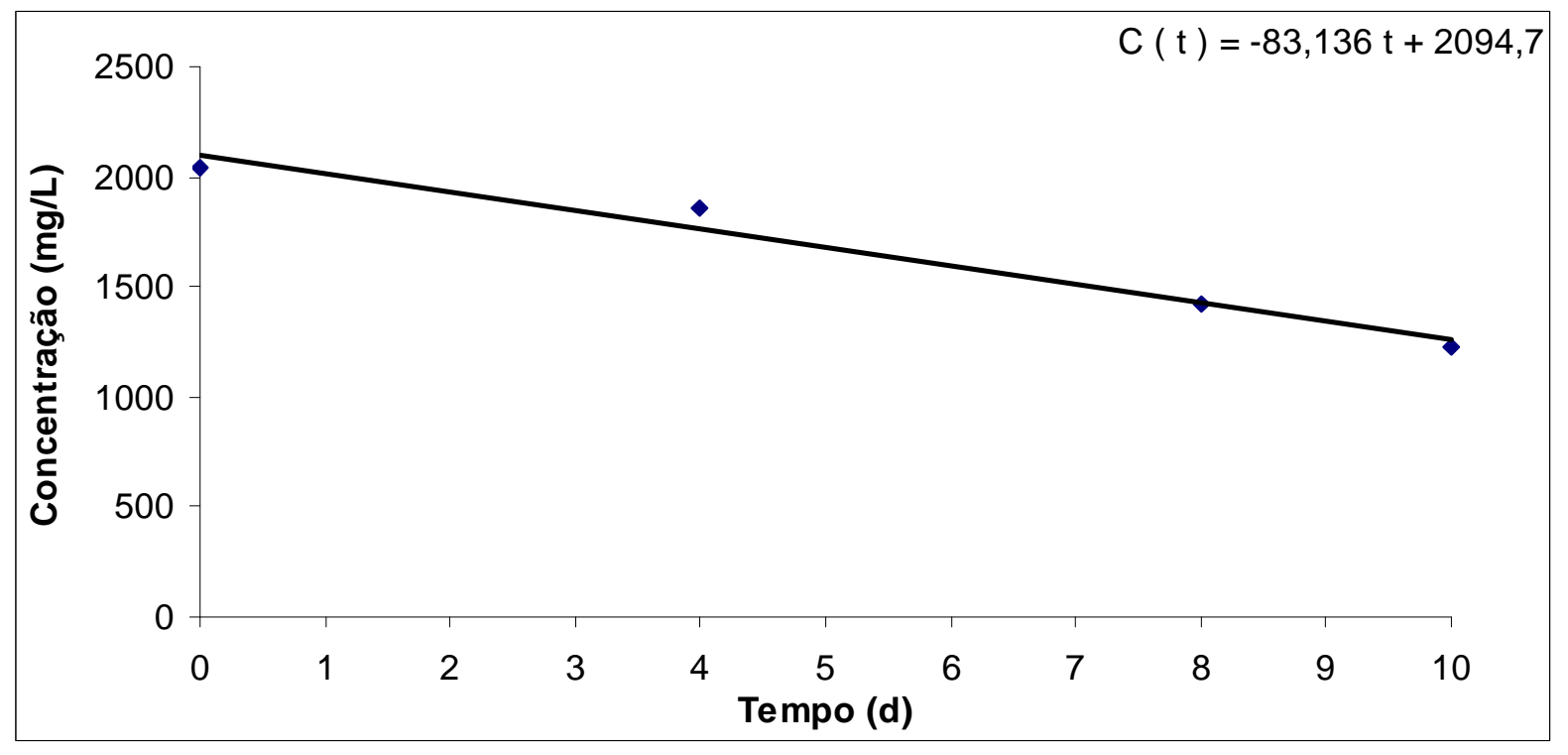

Figura 22 - Concentrações médias de $\mathrm{N}-\mathrm{NH}_{3}$ durante os ciclos de "Stripping" - Aterro Bandeirantes

Para os ciclos desta fase em que foi utilizado o aterro bandeirantes, a taxa média de transferência de $\mathrm{N}-\mathrm{NH}_{3}$ durante o "stripping" foi igual a 83,14 mg N-NH$/ 2$.dia. Vale ressaltar que esta taxa representa o comportamento do lixiviado do aterro bandeirantes durante somente dois ciclos de "stripping". 


\subsubsection{Concentração do nitrogênio amoniacal no final do "stripping" igual a aproximadamente $900 \mathrm{mg} / \mathrm{L}$.}

Como relatado anteriormente, devido às características do lixiviado pós-tratado da fase anterior ("stripping" de amônia até a concentração de $1200 \mathrm{mg} \mathrm{N}-\mathrm{NH}_{4}{ }^{+} / \mathrm{L}$ ), optou-se por efetuar o "stripping" do lixiviado até que a concentração de $\mathrm{N}_{-} \mathrm{NH}_{4}{ }^{+}$do mesmo atingisse o valor de $900 \mathrm{mg} / \mathrm{L}$. Esta mudança teve como objetivo principal obter melhores eficiências para o sistema de remoção de nitrogênio do lixiviado (sistema R-1).

Para tal finalidade, foram realizados 20 ciclos seguidos de "stripping". O lixiviado de aterro utilizado durante todos os ciclos era provindo somente do aterro bandeirantes. Não existe nenhuma justificativa específica em se utilizar somente o lixiviado provindo do aterro bandeirantes a não ser o fato de se padronizar o lixiviado durante a condução da pesquisa. A tabela 11 traz as características físico-químicas durante os 20 ciclos de "stripping".

Tabela 11 - Características físico-químicas do lixiviado durantes os ciclos de "stripping"

\begin{tabular}{|c|c|c|c|c|c|c|c|c|c|c|c|}
\hline Ciclo & $\begin{array}{l}\text { Tempo } \\
\text { (d) }\end{array}$ & $\begin{array}{l}\text { Duração } \\
\text { do ciclo } \\
\text { (d) }\end{array}$ & $\begin{array}{c}\mathrm{DBO} \\
(\mathrm{mg} / \mathrm{l})\end{array}$ & $\begin{array}{c}\mathrm{DQO} \\
(\mathrm{mg} / \mathrm{l})\end{array}$ & $\begin{array}{c}\mathrm{N}- \\
\mathrm{NH}_{3} \\
(\mathrm{mg} / \\
\mathrm{l} /\end{array}$ & $\begin{array}{c}\text { Remoção } \\
\text { de DBO } \\
(\%)\end{array}$ & $\begin{array}{l}\mathrm{COT}^{2}(\mathrm{mg} / \\
\mathrm{L})\end{array}$ & $\mathrm{pH}$ & $\begin{array}{l}\text { Alcalinidade } \\
(\mathrm{mg} \\
\left.\mathrm{CaCO}_{3} / \mathrm{L}\right)\end{array}$ & $\begin{array}{c}\mathrm{ST} \\
(\mathrm{mg} / \mathrm{L})\end{array}$ & $\begin{array}{l}\mathrm{SSV}( \\
\mathrm{mg} / \mathrm{L})\end{array}$ \\
\hline \multirow{5}{*}{1} & 0,0 & & 1900 & 7150 & 2200 & & - & 8,1 & 9860 & 18350 & 110 \\
\hline & 4,0 & & & 5560 & 1730 & & & & & & \\
\hline & 8,0 & & & 4230 & 1350 & & & & & & \\
\hline & 12,0 & & & 3750 & 1030 & & & & & & \\
\hline & 15,0 & 15 & 780 & 3490 & 910 & 58,9 & - & 8,7 & 5780 & 19300 & 195,0 \\
\hline \multirow{5}{*}{2} & 16,0 & & 2050 & 7530 & 2250 & & - & 8,3 & 11550 & 18400 & 90,0 \\
\hline & 20,0 & & & 5850 & 1980 & & & & & & \\
\hline & 24,0 & & & 5240 & 1540 & & & & & & \\
\hline & 28,0 & & & 4620 & 1150 & & & & & & \\
\hline & 32,0 & 15 & 800 & 4100 & 915 & 61,0 & - & 8,8 & 6100 & 20125 & 180,0 \\
\hline
\end{tabular}

\footnotetext{
${ }^{2}$ A análise de COT começou ser realizada a partir do décimo ciclo de stripping
} 


\begin{tabular}{|c|c|c|c|c|c|c|c|c|c|c|c|}
\hline Ciclo & $\begin{array}{c}\text { Tempo } \\
\text { (d) }\end{array}$ & $\begin{array}{l}\text { Duração } \\
\text { do ciclo } \\
\text { (d) }\end{array}$ & $\begin{array}{c}\mathrm{DBO} \\
(\mathrm{mg} / \mathrm{l})\end{array}$ & $\begin{array}{l}\text { DQO } \\
(\mathrm{mg} / \mathrm{l})\end{array}$ & $\begin{array}{c}\mathrm{N}- \\
\mathrm{NH}_{3} \\
(\mathrm{mg} / \\
\mathrm{l})\end{array}$ & $\begin{array}{c}\text { Remoção } \\
\text { de DBO } \\
(\%)\end{array}$ & $\begin{array}{c}\mathrm{COT} \\
(\mathrm{mg} / \mathrm{L})\end{array}$ & $\mathrm{pH}$ & $\begin{array}{c}\text { Alcalinidade } \\
(\mathrm{mg} \\
\left.\mathrm{CaCO}_{3} / \mathrm{L}\right)\end{array}$ & $\begin{array}{c}\mathrm{ST} \\
(\mathrm{mg} / \mathrm{L})\end{array}$ & $\begin{array}{l}\mathrm{SSV}( \\
\mathrm{mg} / \mathrm{L})\end{array}$ \\
\hline \multirow{5}{*}{3} & 33,0 & & 2100 & 6890 & 2380 & & - & 8,2 & 11200 & 17300 & 100 \\
\hline & 37,0 & & & 5530 & 1760 & & & & & & \\
\hline & 41,0 & & & 4890 & 1360 & & & & & & \\
\hline & 45,0 & & & 4110 & 1020 & & & & & & \\
\hline & 48,0 & 15 & 830 & 3850 & 900 & 60,5 & - & 8,7 & 6560 & 18600 & 210 \\
\hline \multirow{5}{*}{4} & 49,0 & & 1960 & 7110 & 2250 & & - & 7,9 & 10100 & 19340 & 75,0 \\
\hline & 53,0 & & & 6150 & 1800 & & & & & & \\
\hline & 57,0 & & & 5580 & 1450 & & & & & & \\
\hline & 61,0 & & & 4900 & 1100 & & & & & & \\
\hline & 64,0 & 15 & 910 & 4350 & 890 & 53,6 & - & 8,5 & 5980 & 20180 & 190,0 \\
\hline \multirow{5}{*}{5} & 65,0 & & 1980 & 6960 & 2180 & & - & 8,3 & 11230 & 18090 & 100 \\
\hline & 69,0 & & & 6100 & 1770 & & & & & & \\
\hline & 73,0 & & & 5670 & 1310 & & & & & & \\
\hline & 77,0 & & & 5150 & 1030 & & & & & & \\
\hline & 81,0 & 15 & 810 & 4850 & 920 & 59,1 & - & 8,7 & 6810 & 19680 & 250 \\
\hline \multirow{5}{*}{6} & 82,0 & & 2480 & 7610 & 2100 & & - & 8,1 & 10880 & 14350 & 110,0 \\
\hline & 86,0 & & & 6130 & 1780 & & & & & & \\
\hline & 90,0 & & & 5560 & 1390 & & & & & & \\
\hline & 94,0 & & & 5100 & 1100 & & & & & & \\
\hline & 97,0 & 15 & 860 & 4750 & 930 & 65,3 & - & 8,6 & 5110 & 15810 & 190,0 \\
\hline \multirow{5}{*}{7} & 98,0 & & 1870 & 6890 & 2230 & & - & 8,0 & 10560 & 18760 & 70 \\
\hline & 102,0 & & & 5990 & 1890 & & & & & & \\
\hline & 106,0 & & & 5300 & 1500 & & & & & & \\
\hline & 110,0 & & & 4180 & 1130 & & & & & & \\
\hline & 113,0 & 15 & 850 & 3760 & 930 & 54,5 & - & 8,7 & 6345 & 18900 & 170 \\
\hline \multirow{5}{*}{8} & 114,0 & & 2020 & 7140 & 2260 & & - & 8,3 & 11150 & 17680 & 65,0 \\
\hline & 118,0 & & & 6030 & 1810 & & & & & & \\
\hline & 122,0 & & & 5550 & 1450 & & & & & & \\
\hline & 126,0 & & & 5250 & 1120 & & & & & & \\
\hline & 129,0 & 15 & 790 & 4880 & 910 & 60,9 & - & 8,8 & 6450 & 19100 & 185,0 \\
\hline \multirow{5}{*}{9} & 130,0 & & 1910 & 6930 & 2180 & & - & 7,9 & 9720 & 18340 & 120 \\
\hline & 134,0 & & & 6100 & 1780 & & & & & & \\
\hline & 138,0 & & & 5230 & 1420 & & & & & & \\
\hline & 142,0 & & & 4700 & 1060 & & & & & & \\
\hline & 146,0 & 15 & 820 & 4030 & 920 & 57,1 & - & 8,6 & 5110 & 19700 & 210 \\
\hline \multirow{5}{*}{10} & 147,0 & & 2100 & 7540 & 2150 & 1850 & 1850 & 8,2 & 10640 & 15640 & 110,0 \\
\hline & 151,0 & & & 6030 & 1720 & & 1620 & & & & \\
\hline & 155,0 & & & 5620 & 1410 & & 1440 & & & & \\
\hline & 159,0 & & & 5040 & 1080 & & 1310 & & & & \\
\hline & 162,0 & 15 & 800 & 4590 & 920 & 61,9 & 1240 & 8,7 & 7140 & 17010 & 250,0 \\
\hline
\end{tabular}




\begin{tabular}{|c|c|c|c|c|c|c|c|c|c|c|c|}
\hline Ciclo & $\begin{array}{l}\text { Tempo } \\
\text { (d) }\end{array}$ & $\begin{array}{l}\text { Duração } \\
\text { do ciclo } \\
\text { (d) }\end{array}$ & $\begin{array}{c}\mathrm{DBO} \\
(\mathrm{mg} / \mathrm{l})\end{array}$ & $\begin{array}{c}\mathrm{DQO} \\
(\mathrm{mg} / \mathrm{l})\end{array}$ & $\begin{array}{c}\mathrm{N}- \\
\mathrm{NH}_{3} \\
(\mathrm{mg} / \\
\mathrm{l})\end{array}$ & $\begin{array}{c}\text { Remoção } \\
\text { de DBO } \\
(\%)\end{array}$ & $\begin{array}{c}\mathrm{COT} \\
(\mathrm{mg} / \mathrm{L})\end{array}$ & $\mathrm{pH}$ & $\begin{array}{l}\text { Alcalinidade } \\
\left(\mathrm{mg}_{3}\right. \\
\left.\mathrm{CaCO}_{3} / \mathrm{L}\right)\end{array}$ & $\begin{array}{c}\mathrm{ST} \\
(\mathrm{mg} / \mathrm{L})\end{array}$ & $\begin{array}{l}\mathrm{SSV}( \\
\mathrm{mg} / \mathrm{L})\end{array}$ \\
\hline \multirow{5}{*}{11} & 163,0 & & 2000 & 7800 & 2130 & & 1830 & 8,0 & 11620 & 21340 & 130 \\
\hline & 167,0 & & & 6780 & 1750 & & 1670 & & & & \\
\hline & 171,0 & & & 5500 & 1390 & & 1410 & & & & \\
\hline & 175,0 & & & 5100 & 1020 & & 1280 & & & & \\
\hline & 178,0 & 15 & 850 & 4910 & 910 & 57,5 & 1120 & 8,7 & 6740 & 22100 & 240 \\
\hline \multirow{5}{*}{12} & 179,0 & & 2120 & 7720 & 2200 & & 1980 & 7,9 & 10120 & 17600 & 80,0 \\
\hline & 183,0 & & & 6680 & 1810 & & 1790 & & & & \\
\hline & 187,0 & & & 5340 & 1400 & & 1610 & & & & \\
\hline & 191,0 & & & 5020 & 1060 & & 1470 & & & & \\
\hline & 194,0 & 15 & 860 & 4560 & 920 & 59,4 & 1360 & 8,4 & 6890 & 18560 & 175,0 \\
\hline \multirow{5}{*}{13} & 195,0 & & 1910 & 7830 & 2150 & & 2110 & 8,0 & 9875 & 17890 & 80 \\
\hline & 199,0 & & & 6680 & 1810 & & 1900 & & & & \\
\hline & 203,0 & & & 5340 & 1400 & & 1710 & & & & \\
\hline & 207,0 & & & 5020 & 1060 & & 1560 & & & & \\
\hline & 210,0 & 15 & 890 & 4560 & 920 & 53,4 & 1490 & 8,6 & 6500 & 19100 & 230 \\
\hline \multirow{5}{*}{14} & 211,0 & & 2100 & 7530 & 2200 & & 1940 & 8,1 & 12440 & 16780 & 110,0 \\
\hline & 215,0 & & & 6380 & 1760 & & 1810 & & & & \\
\hline & 219,0 & & & 5100 & 1380 & & 1680 & & & & \\
\hline & 222,0 & & & 4910 & 1100 & & 1430 & & & & \\
\hline & 226,0 & 15 & 910 & 4360 & 930 & 56,7 & 1310 & 8,8 & 7100 & 17800 & 200,0 \\
\hline \multirow{5}{*}{15} & 227,0 & & 2500 & 8000 & 2300 & & 1780 & 8,1 & 11560 & 19340 & 70 \\
\hline & 231,0 & & & 7150 & 1910 & & 1600 & & & & \\
\hline & 235,0 & & & 6600 & 1430 & & 1480 & & & & \\
\hline & 239,0 & & & 6150 & 1160 & & 1320 & & & & \\
\hline & 242,0 & 15 & 930 & 5780 & 910 & 62,8 & 1210 & 8,7 & 6680 & 21560 & 150 \\
\hline \multirow{5}{*}{16} & 243,0 & & 1950 & 7150 & 2130 & & 1560 & 8,0 & 9890 & 18670 & 40,0 \\
\hline & 247,0 & & & 6780 & 1750 & & 1410 & & & & \\
\hline & 251,0 & & & 5600 & 1400 & & 1260 & & & & \\
\hline & 255,0 & & & 5120 & 1020 & & 1100 & & & & \\
\hline & 258,0 & 15 & 810 & 4760 & 915 & 58,5 & 1010 & 8,7 & 5760 & 19500 & 160,0 \\
\hline \multirow{5}{*}{17} & 259,0 & & 2210 & 7520 & 2200 & & 2230 & 8,1 & 10140 & 19540 & 110 \\
\hline & 263,0 & & & 6880 & 1830 & & 2010 & & & & \\
\hline & 267,0 & & & 5940 & 1360 & & 1890 & & & & \\
\hline & 271,0 & & & 5120 & 1000 & & 1710 & & & & \\
\hline & 274,0 & 15 & 980 & 4760 & 910 & 55,7 & 1660 & 8,6 & 6120 & 21400 & 190 \\
\hline \multirow{5}{*}{18} & 275,0 & & 1980 & 6800 & 2020 & & 1870 & 7,9 & 10900 & 19320 & 90,0 \\
\hline & 279,0 & & & 6280 & 1680 & & 1710 & & & & \\
\hline & 283,0 & & & 5740 & 1350 & & 1570 & & & & \\
\hline & 287,0 & & & 5320 & 1040 & & 1420 & & & & \\
\hline & 291,0 & 15 & 860 & 5040 & 930 & 56,6 & 1350 & 8,5 & 7450 & 20780 & 215,0 \\
\hline
\end{tabular}




\begin{tabular}{|c|c|c|c|c|c|c|c|c|c|c|c|}
\hline Ciclo & $\begin{array}{l}\text { Tempo } \\
\text { (d) }\end{array}$ & $\begin{array}{l}\text { Duração } \\
\text { do ciclo } \\
\text { (d) }\end{array}$ & $\begin{array}{c}\mathrm{DBO} \\
(\mathrm{mg} / \mathrm{l})\end{array}$ & $\begin{array}{c}\text { DQO } \\
(\mathrm{mg} / \mathrm{l})\end{array}$ & $\begin{array}{c}\mathrm{N}- \\
\mathrm{NH}_{3} \\
(\mathrm{mg} / \\
\mathrm{l} /\end{array}$ & $\begin{array}{c}\text { Remoção } \\
\text { de DBO } \\
(\%)\end{array}$ & $\begin{array}{c}\text { COT } \\
(\mathrm{mg} / \mathrm{L})\end{array}$ & $\mathrm{pH}$ & $\begin{array}{c}\text { Alcalinidade } \\
\left(\mathrm{mg}_{3} / \mathrm{L}\right) \\
\mathrm{CaCO}^{2}\end{array}$ & $\begin{array}{c}\mathrm{ST} \\
(\mathrm{mg} / \mathrm{L})\end{array}$ & $\begin{array}{l}\mathrm{SSV}( \\
\mathrm{mg} / \mathrm{L})\end{array}$ \\
\hline \multirow{5}{*}{19} & 292,0 & & 2260 & 7670 & 1950 & & 1980 & 8,2 & 11340 & 15690 & 85 \\
\hline & 296,0 & & & 7000 & 1810 & & 1780 & & & & \\
\hline & 300,0 & & & 6540 & 1400 & & 1610 & & & & \\
\hline & 304,0 & & & 5850 & 1060 & & 1460 & & & & \\
\hline & 307,0 & 15 & 935 & 4870 & 920 & 58,6 & 1370 & 8,7 & 6780 & 16560 & 170 \\
\hline \multirow{5}{*}{20} & 308,0 & & 1800 & 7700 & 2210 & & 2140 & 8,0 & 9650 & 20670 & 110,0 \\
\hline & 312,0 & & & 6870 & 1840 & & 1910 & & & & \\
\hline & 316,0 & & & 6010 & 1450 & & 1760 & & & & \\
\hline & 320,0 & & & 5380 & 1080 & & 1620 & & & & \\
\hline & 323,0 & 15 & 800 & 4690 & 930 & 55,6 & 1530 & 8,6 & 5780 & 21790 & 250,0 \\
\hline
\end{tabular}

As figuras 24 e 25 demonstram o perfil de variação das concentrações de DQO para os 8 primeiros ciclos do "stripping" utilizando-se o sistema R-2, já as figuras 26,27 e 28 trazem o perfil de variação das concentrações de DQO e COT referentes aos últimos 12 ciclos do "stripping". É importante salientar que os ciclos foram seqüenciais por isso, as figuras trazem os dados de $4 \mathrm{em} 4$ ciclos.

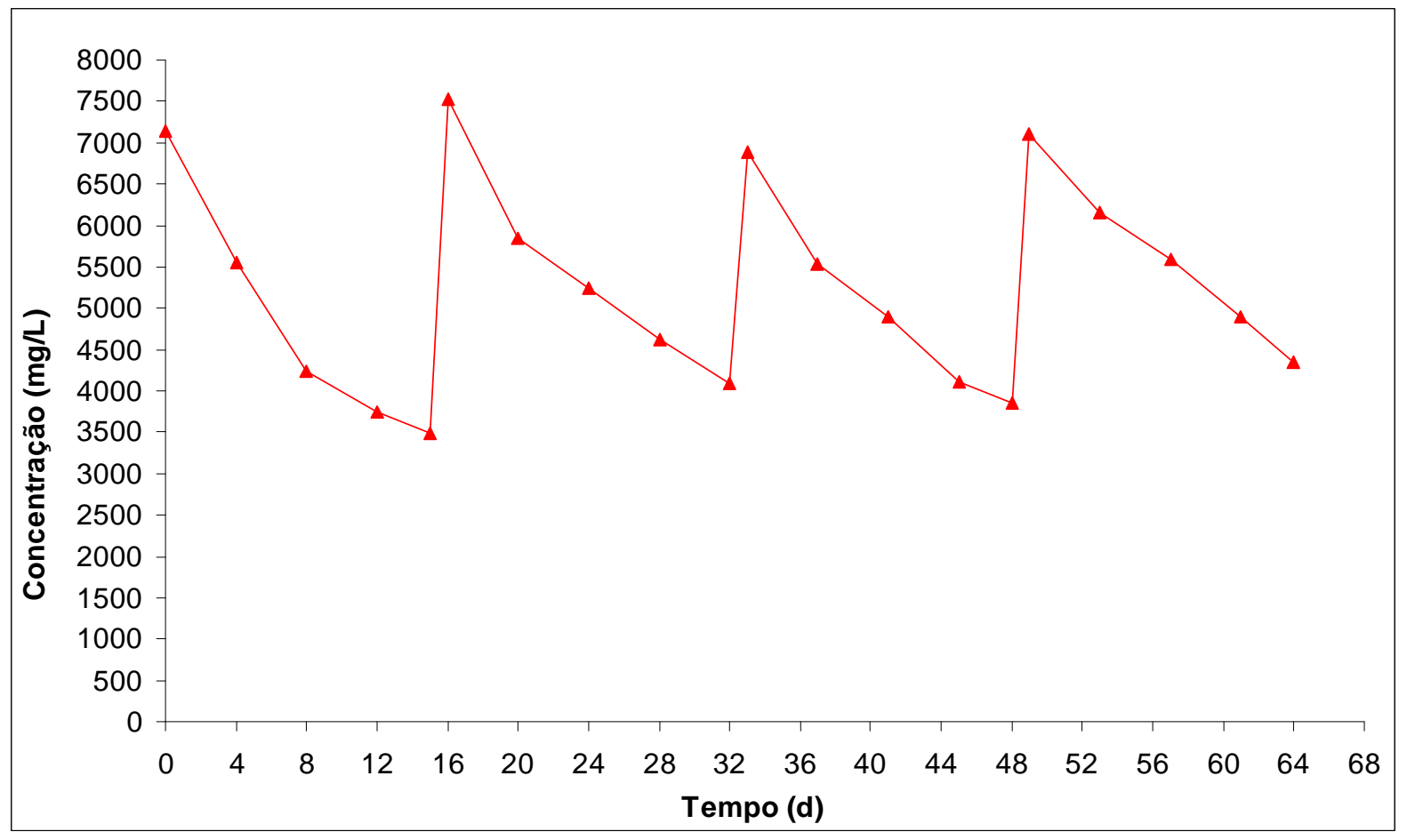

Figura 23 - Perfis temporais da concentração de DQO dos primeiros 4 primeiros ciclos de "stripping" do lixiviado bruto (sistema R-2). 


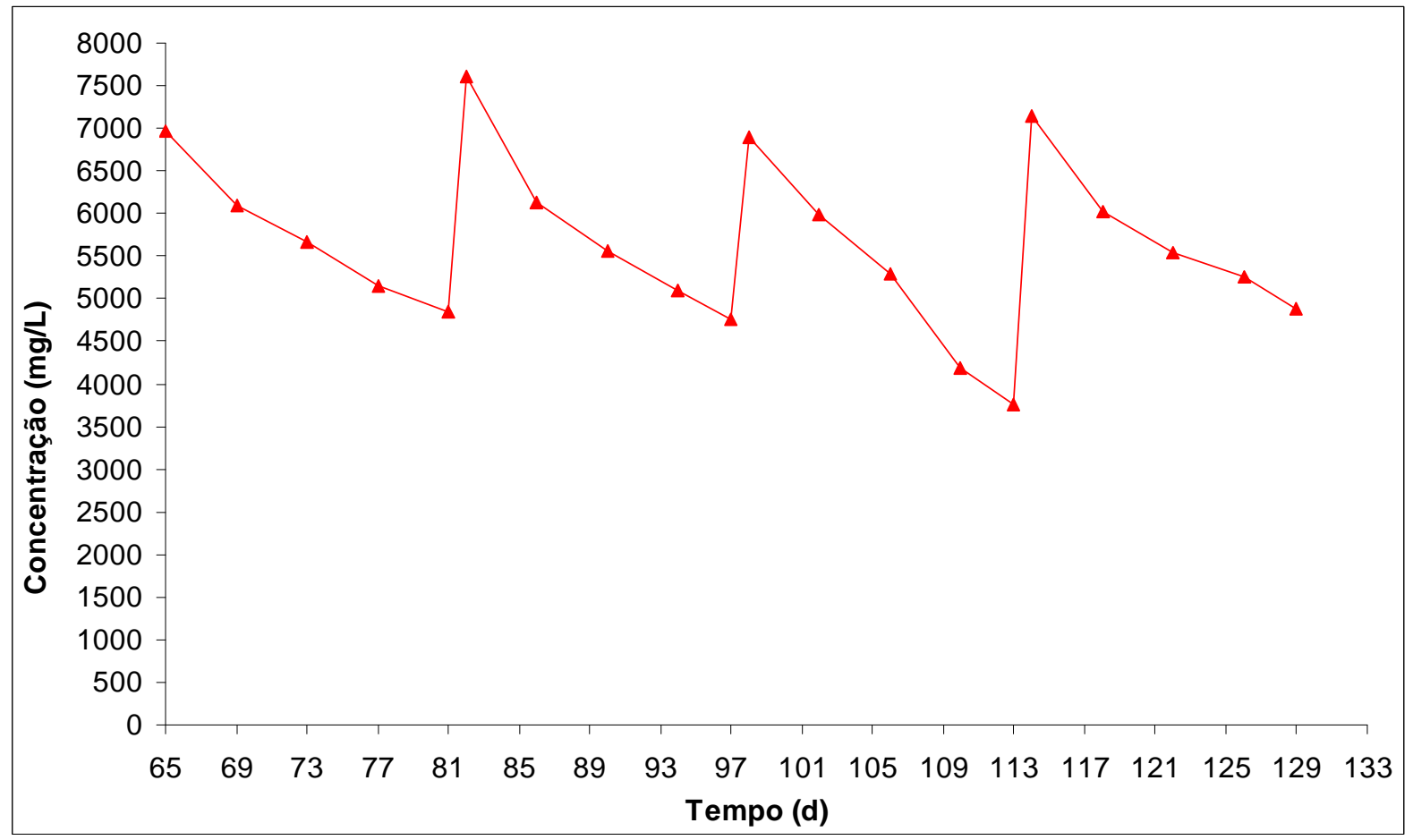

Figura 24 - Perfis temporais da concentração de DQO dos primeiros 4 ciclos seguintes de "stripping" do lixiviado bruto (sistema R-2).

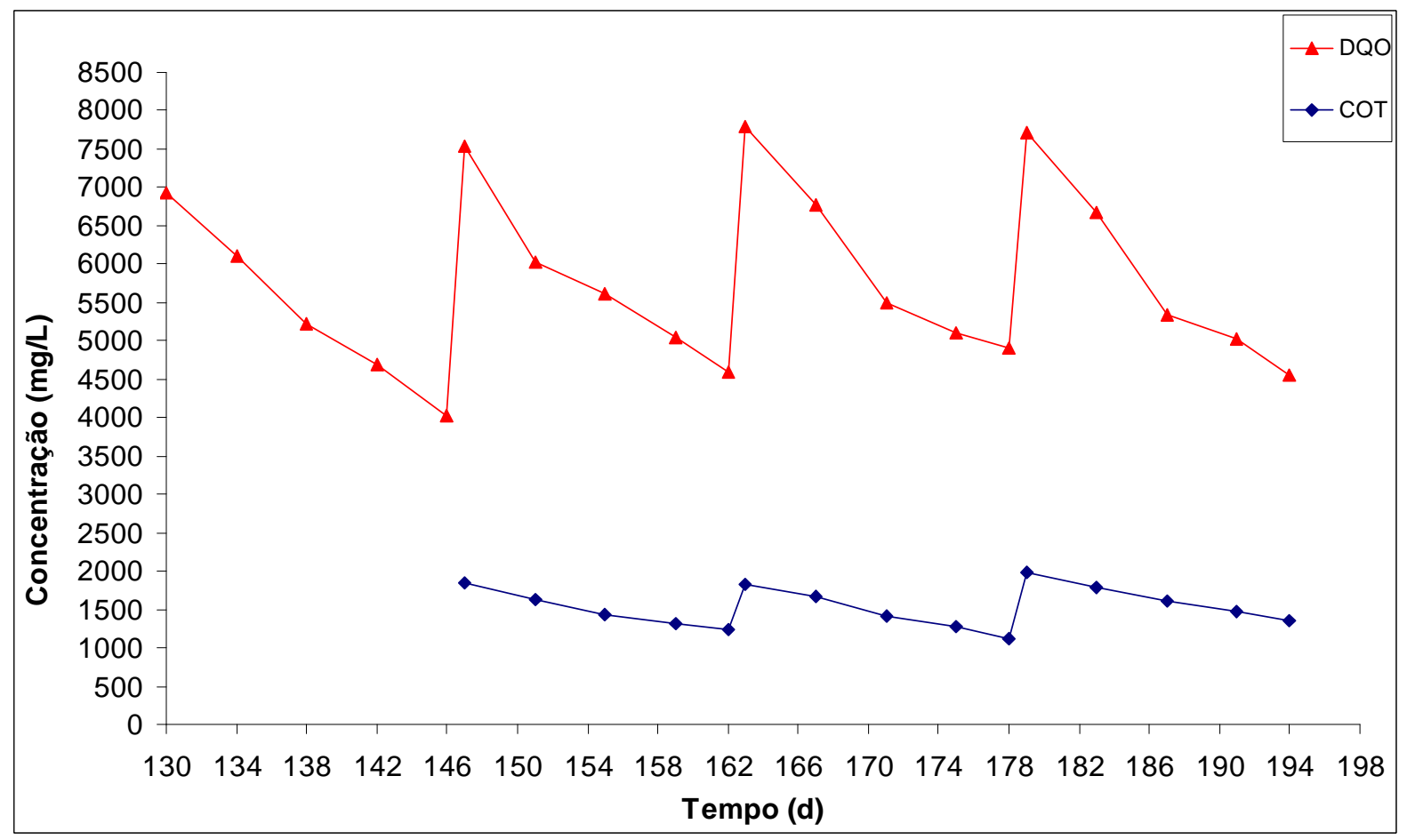

Figura 25 - Perfis temporais das concentrações de DQO e COT dos 4 ciclos seguintes de "stripping" do lixiviado bruto (sistema R-2). 


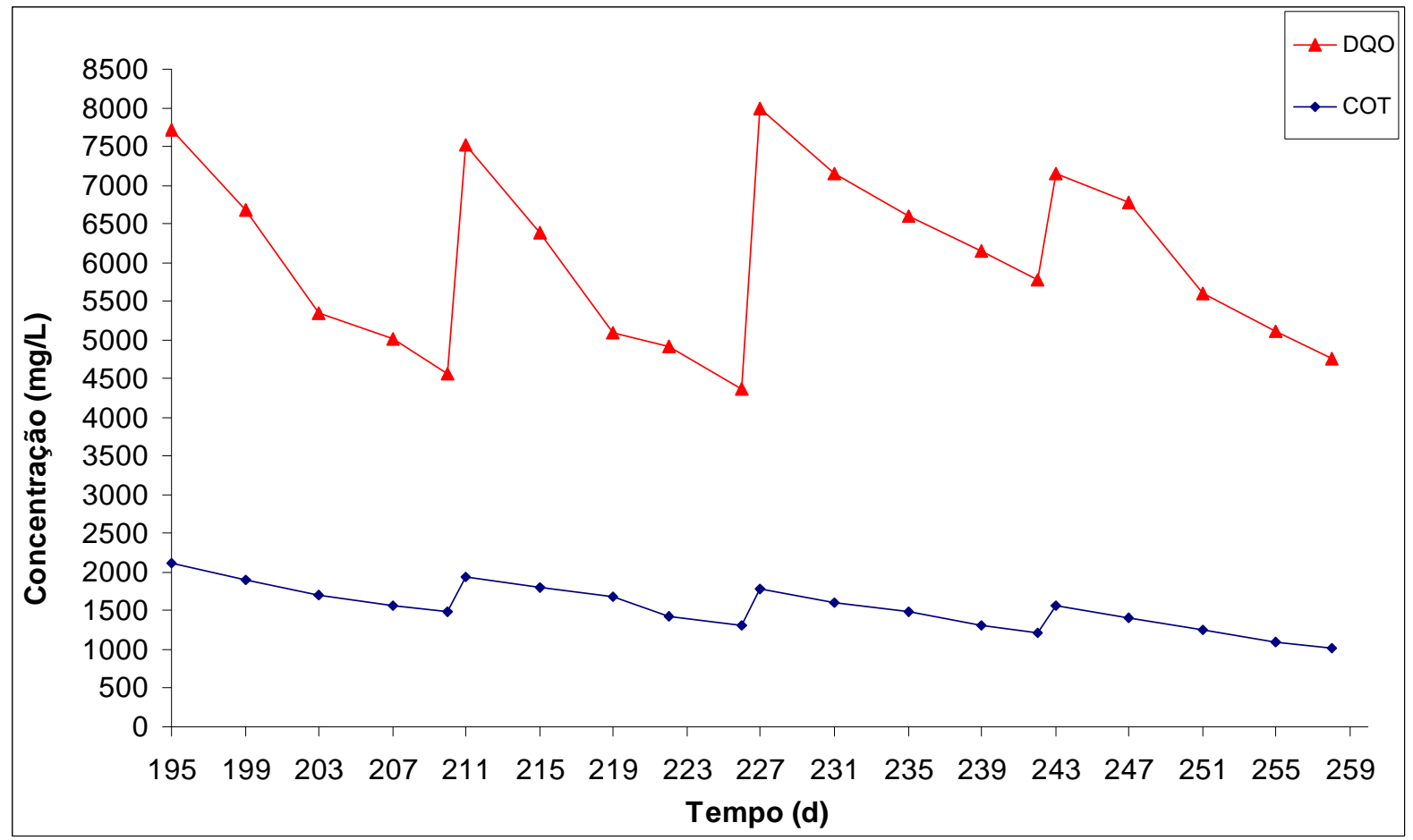

Figura 26 - Perfis temporais das concentrações de DQO e COT dos 4 ciclos seguintes de "stripping" do lixiviado bruto (sistema R-2).

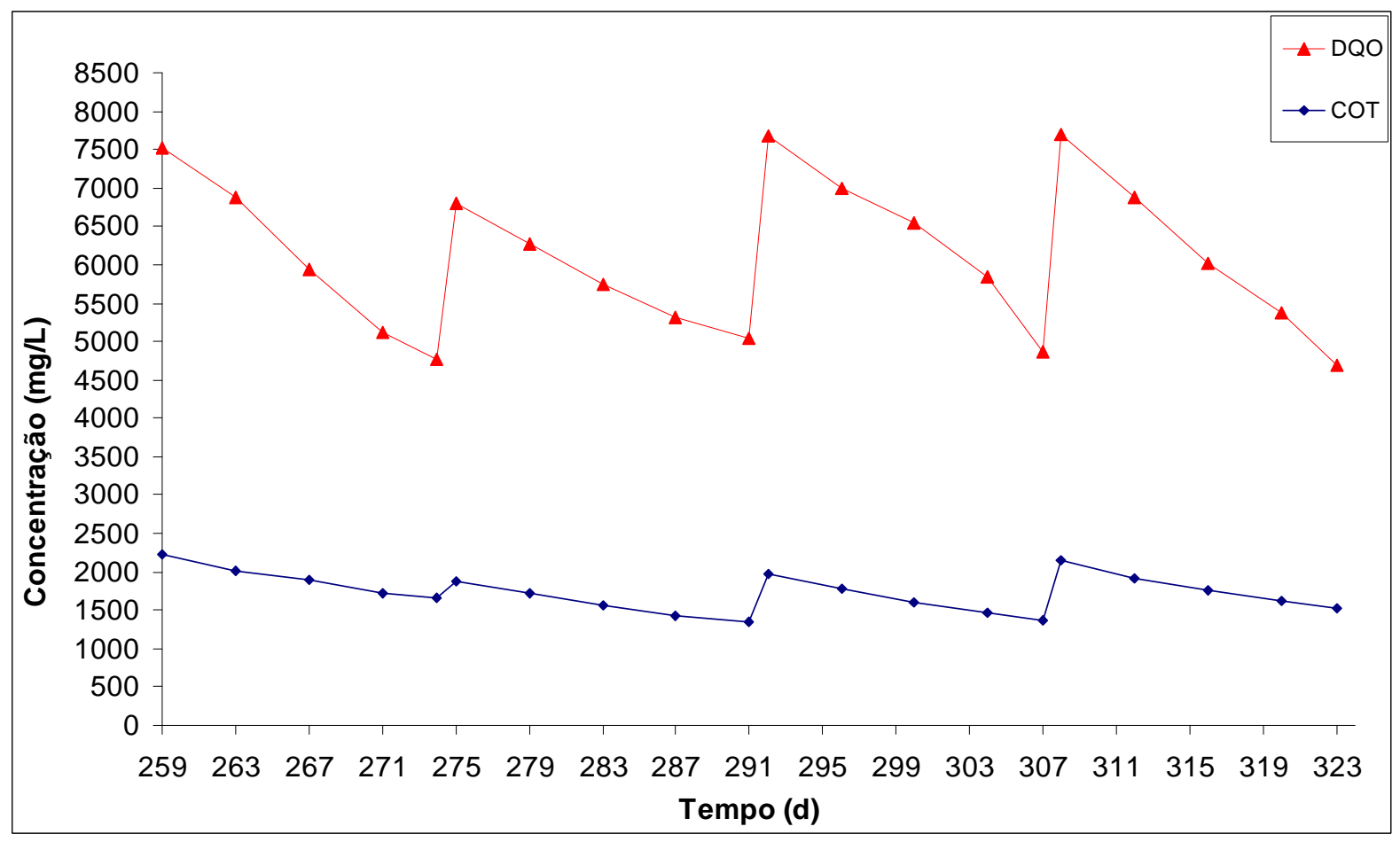

Figura 27 - Perfis temporais das concentrações de DQO e COT dos 4 últimos ciclos de "stripping" do lixiviado bruto (sistema R-2). 
Analisando-se as figuras 24 a 28 nota-se que, assim como na primeira fase da pesquisa, houve uma diminuição da concentração da matéria orgânica presente no lixiviado. Nesta fase a redução foi maior que na primeira fase já que, o tempo dos ciclos de "stripping" também foram maiores.

As remoções médias de DQO, DBO e COT durante os ciclos de "stripping" foram de $38,58 \%$ e $31 \%$ respectivamente.

Assim como na primeira fase do "stripping" houve um aumento na concentração de sólidos no sistema, denotando este fato para um possível crescimento de biomassa no reator, podendo ser esta biomassa a responsável pela diminuição de uma parcela da matéria orgânica do lixiviado. Nota-se através das figuras 24 a 28 que a redução da DQO foi maior nos primeiros dias de "stripping". A volatilização de alguns compostos como ácidos orgânicos voláteis pode também ser uma das causas da maior diminuição da $\mathrm{DQO}$ do percolado nos primeiros dias do ciclo.

$\mathrm{Na}$ figura 29é apresentado o perfil do pH durante o primeiro ciclo de "stripping", e na figura 30 é apresentado o perfil da concentração de alcalinidade durante o mesmo ciclo.

$\mathrm{O} \mathrm{pH}$ do lixiviado, como mostra a tabela 11, teve um aumento mais acentuado nesta fase da pesquisa obviamente causado pelo maior tempo de ciclo. Já a alcalinidade, assim como na fase anterior, apresentou uma queda. O motivo do aumento do $\mathrm{pH}$ bem como a diminuição da alcalinidade foram possivelmente os mesmos da primeira fase do "stripping".

A figura 31 apresenta a distribuição da concentração de $\mathrm{N}-\mathrm{NH}_{3}$ durante os 20 ciclos de "stripping" utilizando-se o sistema R-2. Já a figura 32 traz gráfico dos valores médios das concentrações de $\mathrm{N}-\mathrm{NH}_{3}$ durante o ciclo. 


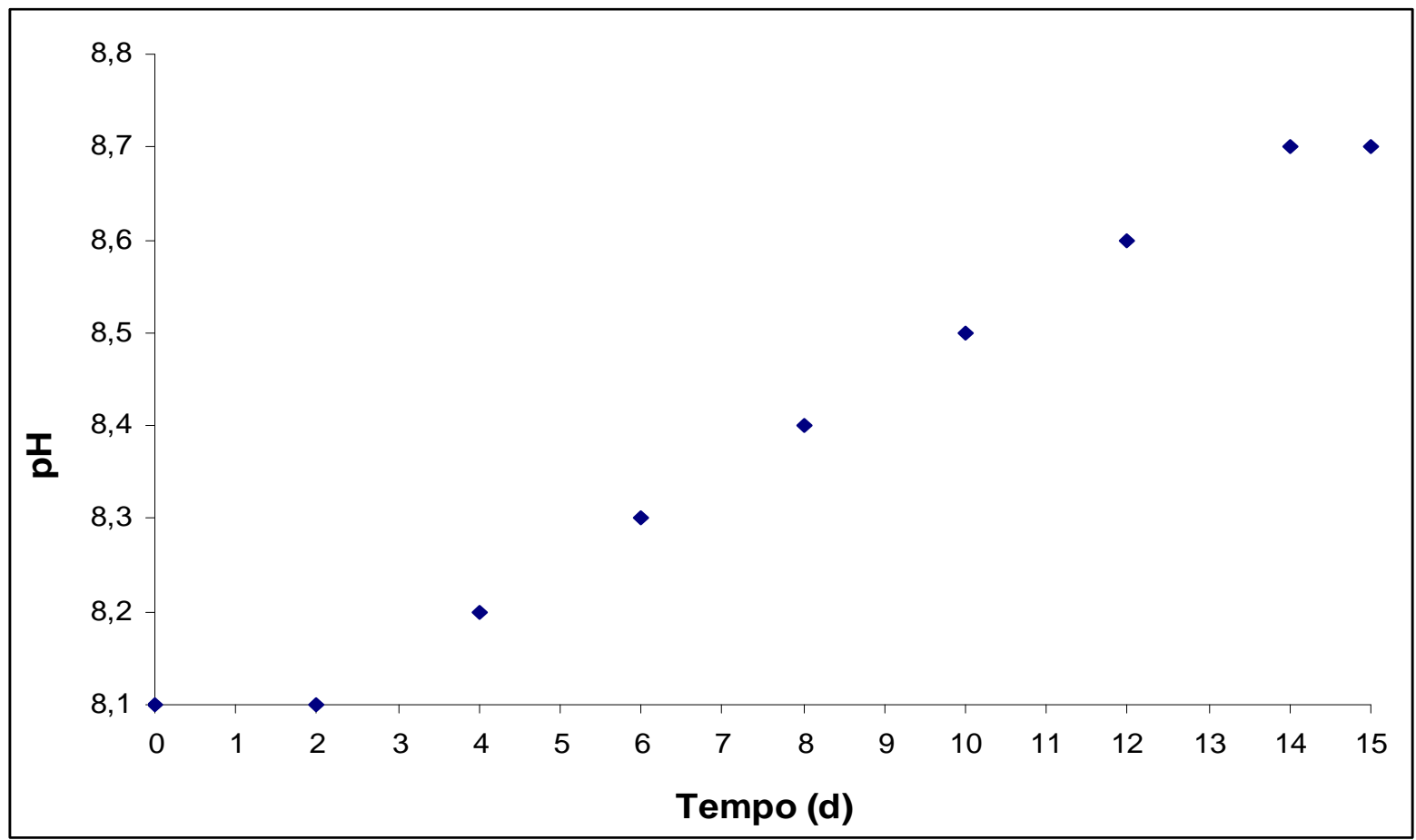

Figura 28 - Variação temporal do pH do lixiviado durante o primeiro ciclo de "stripping" (sistema R-2/Fase 2).

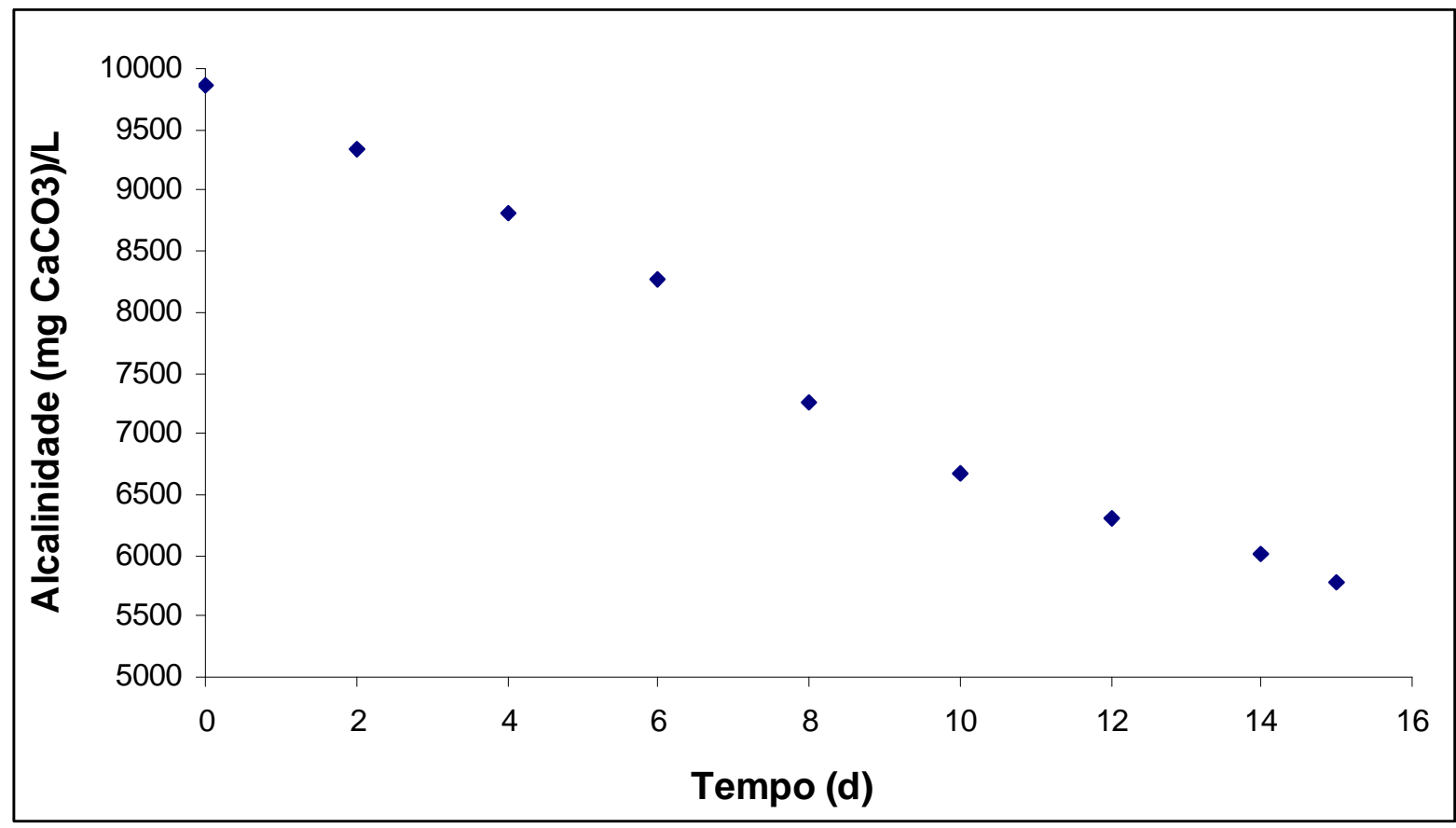

Figura 29 - Variação temporal da alcalinidade total do lixiviado durante o primeiro ciclo de "stripping" (sistema R-2/Fase 1). 


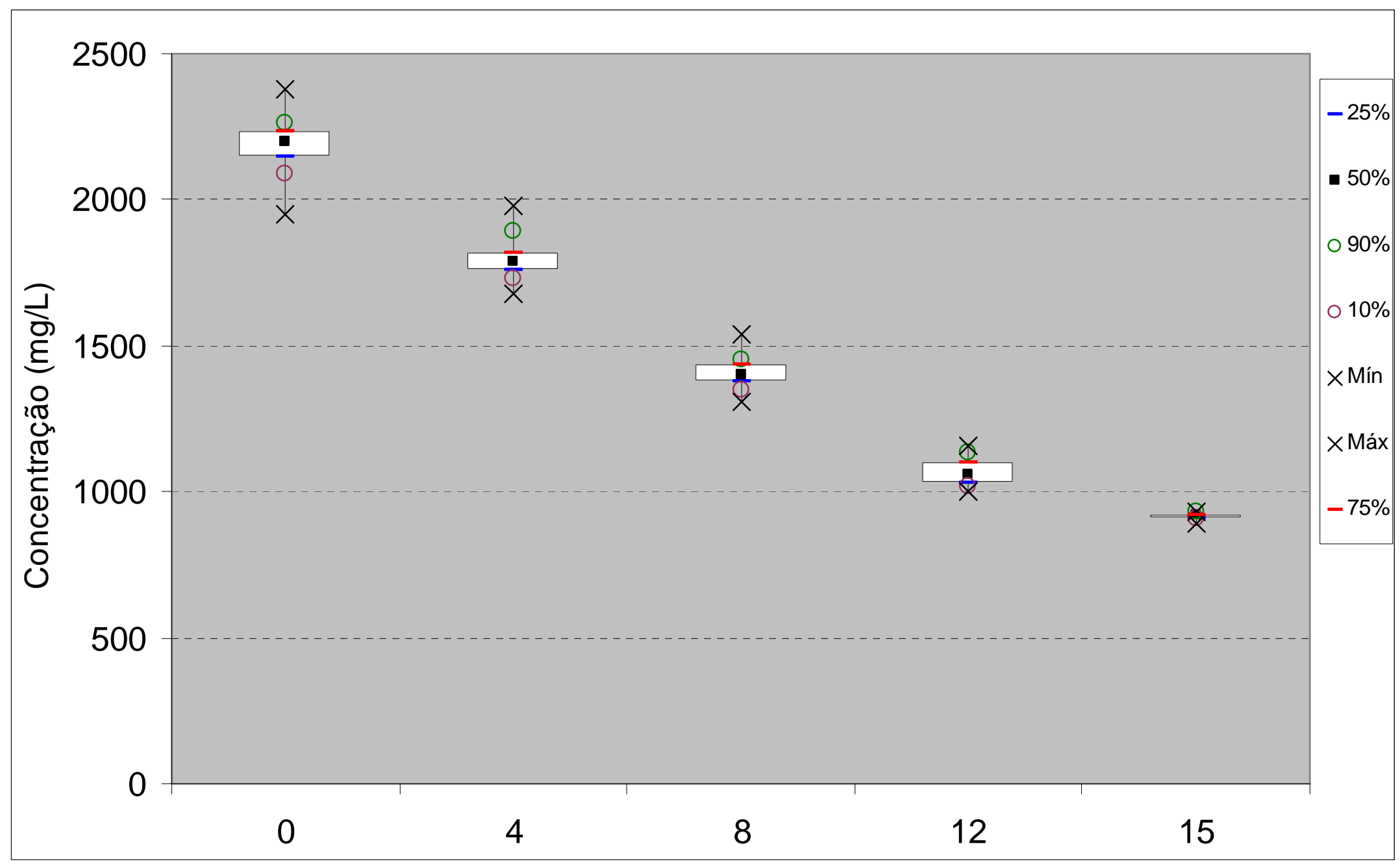

Figura 30 - Perfis das concentrações de $\mathbf{N}-\mathrm{NH}_{3}$ durante os 20 ciclos de "stripping". 


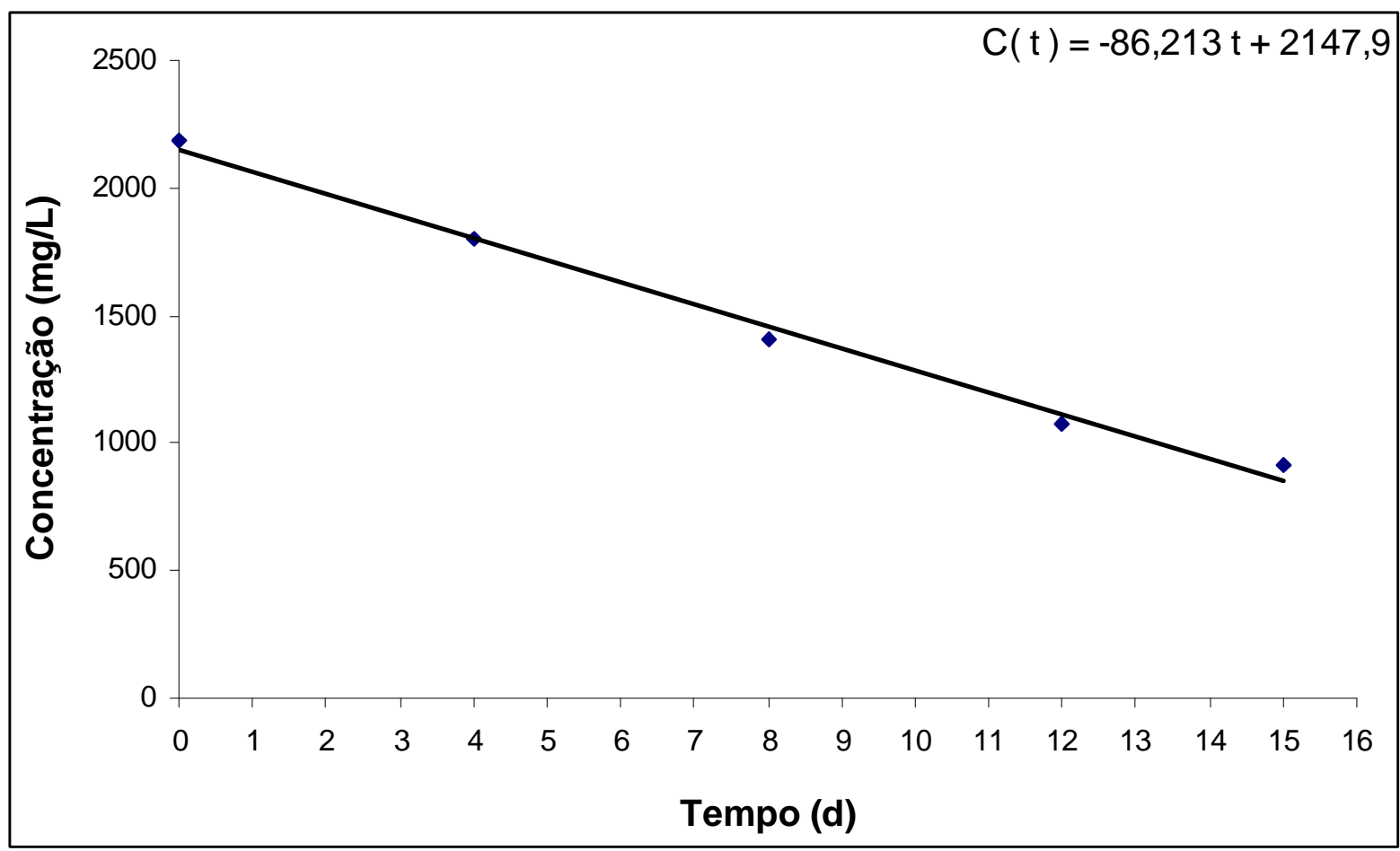

Figura 31 - Concentrações médias de $\mathrm{N}-\mathrm{NH}_{3}$ durante os ciclos de "Stripping" - Sistema R-2

Através da figura 32 observa-se que a equação que determina a variação de $\mathrm{N}-\mathrm{NH} 3$ ao longo do tempo é de ordem zero, sendo a taxa média de remoção de amônia ao longo do tempo igual a 86,2 mg N-NH$/$ L.dia. 


\subsubsection{PRÉ-TRATAMENTO DO LIXIVIADO POR "STRIPPING" DE AMÔNIA COM SISTEMA DE AERAÇÃO}

Assim como no sistema R-2, não houve controle de nenhum parâmetro ambiental do "stripping" de amônia através do sistema de aeração (COL-1) com exceção é claro da vazão de ar introduzida na massa líquida do sistema, que se manteve em torno de $35 \mathrm{~L} / \mathrm{h}$ durante o ciclo de tratamento.

\subsubsection{Concentração do nitrogênio amoniacal no final do "stripping" igual a aproximadamente $1200 \mathrm{mg} / \mathrm{L}$}

Paralelamente ao sistema R-2 foi feito o "stripping" de amônia utilizando um sistema de aeração por bolhas grossas. A tabela 12 traz as características físico-químicas do lixiviado durante os ciclos da fase 1 .

Tabela 12 - Características físico-químicas do lixiviado durantes os ciclos de "stripping"

\begin{tabular}{|c|c|c|c|c|c|c|c|c|c|c|c|}
\hline Ciclo & $\begin{array}{c}\text { Tempo } \\
\text { (d) }\end{array}$ & $\begin{array}{l}\text { Duração } \\
\text { do ciclo } \\
\text { (d) }\end{array}$ & $\begin{array}{c}\mathrm{DBO} \\
(\mathrm{mg} / \mathrm{l})\end{array}$ & $\begin{array}{l}\text { DQO } \\
(\mathrm{mg} / \mathrm{l})\end{array}$ & $\begin{array}{c}\mathrm{N}- \\
\mathrm{NH}_{3} \\
(\mathrm{mg} / \mathrm{l})\end{array}$ & $\begin{array}{c}\text { Remoção } \\
\text { de DBO } \\
(\%)\end{array}$ & $\begin{array}{c}\text { Remoção } \\
\text { DQO } \\
(\%)\end{array}$ & $\mathrm{pH}$ & $\begin{array}{l}\text { Alcalinidade } \\
\qquad(\mathrm{mg} \\
\left.\mathrm{CaCO}_{3} / \mathrm{L}\right)\end{array}$ & $\begin{array}{c}\text { SSV } \\
(\mathrm{mg} / \\
\mathrm{L})\end{array}$ & $\begin{array}{c}\mathrm{ST} \\
(\mathrm{mg} / \mathrm{L} \\
)\end{array}$ \\
\hline \multirow{4}{*}{$\begin{array}{c}1 \\
\text { (São } \\
\text { João) }\end{array}$} & 0,0 & & 2200 & 7500 & 2200 & 46,3 & 23,1 & 8,1 & 9880 & 90 & 16780 \\
\hline & 4,0 & & & 6750 & 1890 & & & & & & \\
\hline & 8,0 & & & 6050 & 1480 & & & & & & \\
\hline & 11,0 & 11,0 & 1180 & 5770 & 1230 & & & 8,5 & 6670 & 190 & 17530 \\
\hline \multirow{4}{*}{$\begin{array}{c}2 \\
\text { (Bandei } \\
\text {-rantes) }\end{array}$} & 12,0 & & 2050 & 7150 & 2130 & 46,3 & 21,4 & 8,0 & 11230 & 110 & 18760 \\
\hline & 16,0 & & & 6610 & 1910 & & & & & & \\
\hline & 20,0 & & & 5910 & 1450 & & & & & & \\
\hline & 22,0 & 11,0 & 1100 & 5620 & 1250 & & & 8,4 & 7790 & 230 & 19460 \\
\hline \multirow{4}{*}{$\begin{array}{c}3 \\
\text { (Bandei } \\
\text {-rantes) }\end{array}$} & 23,0 & & 1940 & 6890 & 1950 & 40,7 & 21,7 & 8,2 & 11120 & 100 & 19100 \\
\hline & 27,0 & & & 6250 & 1840 & & & & & & \\
\hline & 31,0 & & & 5610 & 1410 & & & & & & \\
\hline & 33,0 & 11,0 & 1150 & 5390 & 1200 & & & 8,5 & 8120 & 210 & 19860 \\
\hline \multirow{4}{*}{$\begin{array}{c}4 \\
\text { (São } \\
\text { João) }\end{array}$} & 34,0 & & 2150 & 7340 & 2120 & 41,9 & 20,9 & 8,1 & 9750 & 130 & 17900 \\
\hline & 38,0 & & & 6770 & 1810 & & & & & & \\
\hline & 42,0 & & & 6130 & 1400 & & & & & & \\
\hline & 45,0 & 11,0 & 1250 & 5800 & 1250 & & & 8,4 & 6460 & 240 & 18750 \\
\hline \multirow{4}{*}{$\begin{array}{c}5 \\
\text { (São } \\
\text { João) }\end{array}$} & 46,0 & & 2180 & 7100 & 1940 & 42,2 & 21,1 & 8,0 & 8970 & 80 & 18860 \\
\hline & 50,0 & & & 6510 & 1770 & & & & & & \\
\hline & 54,0 & & & 5910 & 1380 & & & & & & \\
\hline & 56,0 & 11,0 & 1260 & 5600 & 1230 & & & 8,3 & 6190 & 190 & 19400 \\
\hline
\end{tabular}

Já a figura 33 demonstra o perfil temporal da concentração de $\mathrm{N}^{-\mathrm{NH}_{3}}$ e DQO durante os ciclos de "stripping" da primeira fase utilizando - se o sistema COL-1. 


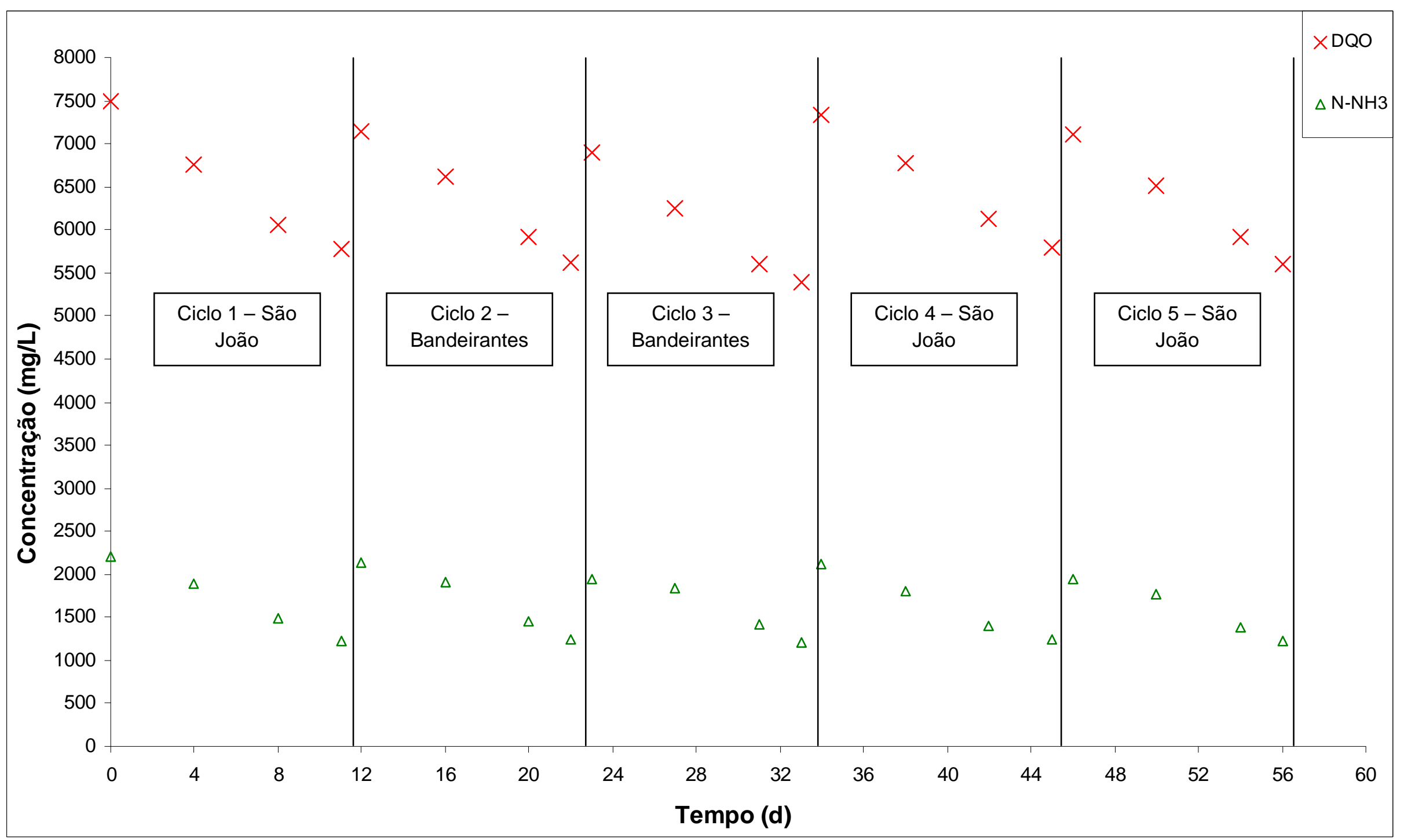

Figura 32 - Perfis temporais das concentrações de DQO e N-NH ${ }_{3}$ durante os ciclos de "stripping" da primeira fase - Sistema COL-1 
Observando-se a figura 30 e a tabela 12 nota-se que o sistema COL-1 se comportou de maneira semelhante ao sistema R-2 no que se refere à redução de $D Q O$ e DBO, porém a redução de DQO e DBO foi maior no sistema COL-1 do que no sistema R2. A remoção média de $\mathrm{DQO}$ e DBO no sistema COL-1 foi de 21,7 e $46,5 \%$ respectivamente, já no sistema R-2 estes valores foram de 19,7\% (DQO) e 37,4 \% (DBO).

Assim como no "stripping" por agitação mecânica, houve um aumento do pH e uma diminuição da alcalinidade do lixiviado durante os ciclos do sistema COL-1.

$\mathrm{O}$ comportamento do sistema COL-1 no que se refere à remoção de $\mathrm{N}-\mathrm{NH}_{3}$ foi semelhante ao apresentado no sistema R-2. A figura 34 traz a distribuição da concentração de $\mathrm{N}-\mathrm{NH}_{3}$ quando se utilizou o aterro São João e a figura 35 a mesma distribuição relativa ao aterro Bandeirantes. As figuras 36 e 37 trazem o perfil das concentrações médias de $\mathrm{N}_{-} \mathrm{NH}_{3}$ do aterro São João e Bandeirantes respectivamente. De acordo com as figuras 36 e 37 a taxa de transferência média de amônia durante o "stripping" foi de 79,26 mg N-NH$/$ L.dia para os ciclos utilizando o aterro São João e $78 \mathrm{mg} \mathrm{N}-\mathrm{NH}_{3} / \mathrm{L}$.dia para os ciclos utilizando o aterro Bandeirantes.

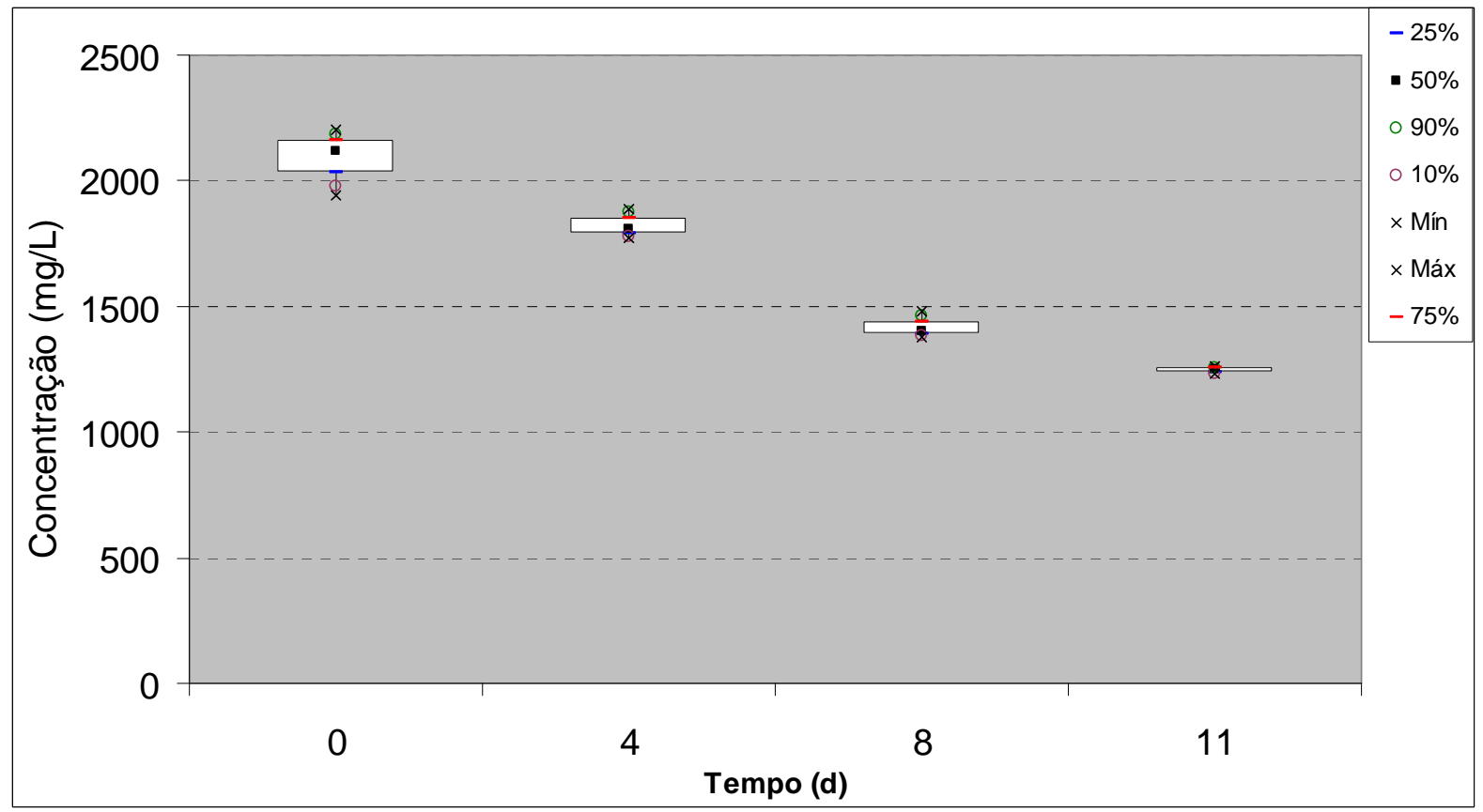

Figura 33 - Perfis das concentrações de $\mathrm{N}-\mathrm{NH}_{3}$ durante os ciclos de "stripping" do lixiviado provindo do aterro São João - concentração de $\mathrm{N}-\mathrm{NH}_{3}$ final de aproximadamente $1200 \mathrm{mg} / \mathrm{L}$. 


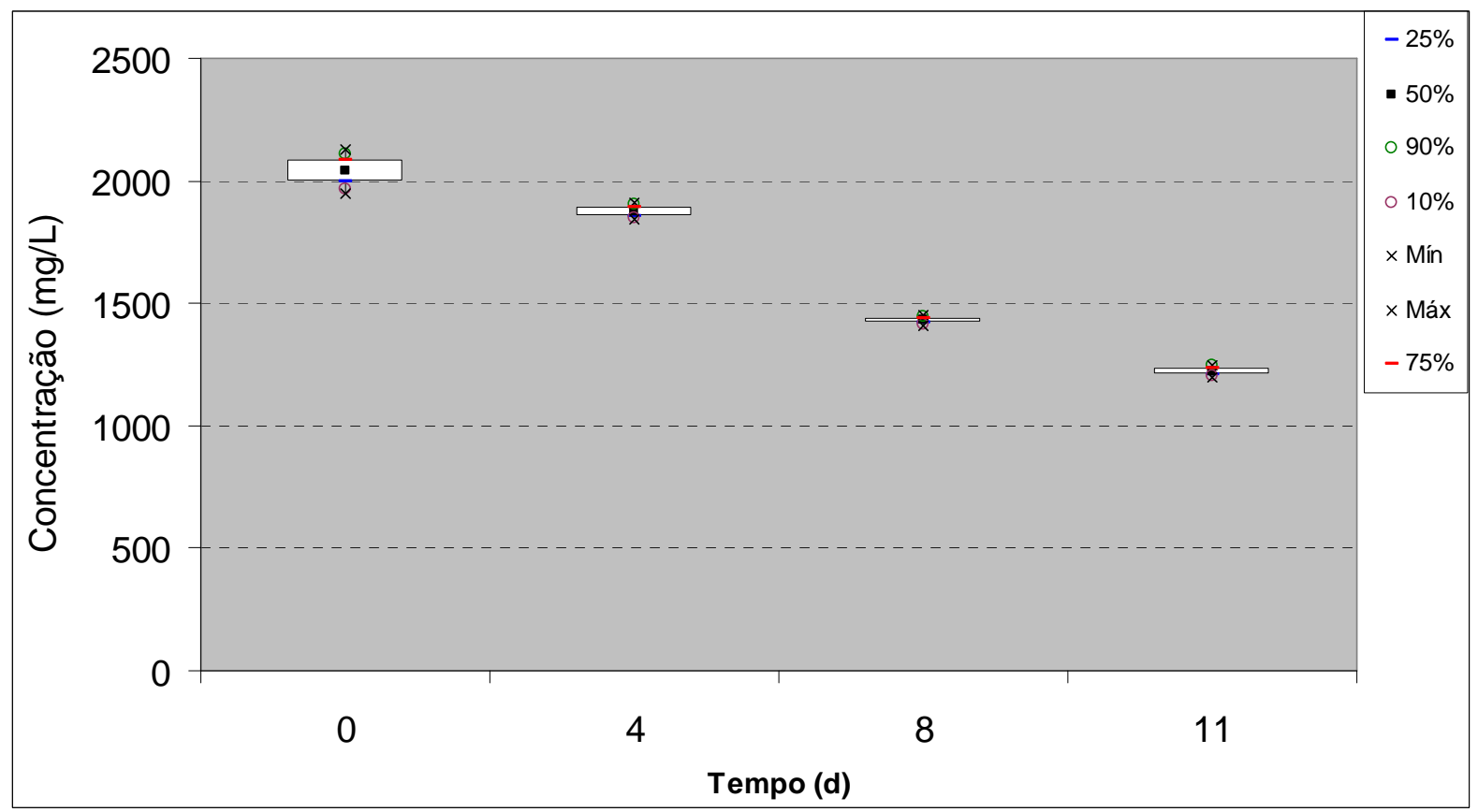

Figura 34 - Perfis das concentrações de $\mathrm{N}-\mathrm{NH}_{3}$ durante os ciclos de "stripping" do lixiviado provindo do aterro Bandeirantes - concentração de $\mathrm{N}-\mathrm{NH}_{3}$ final de aproximadamente 1200 $\mathrm{mg} / \mathrm{L}$.

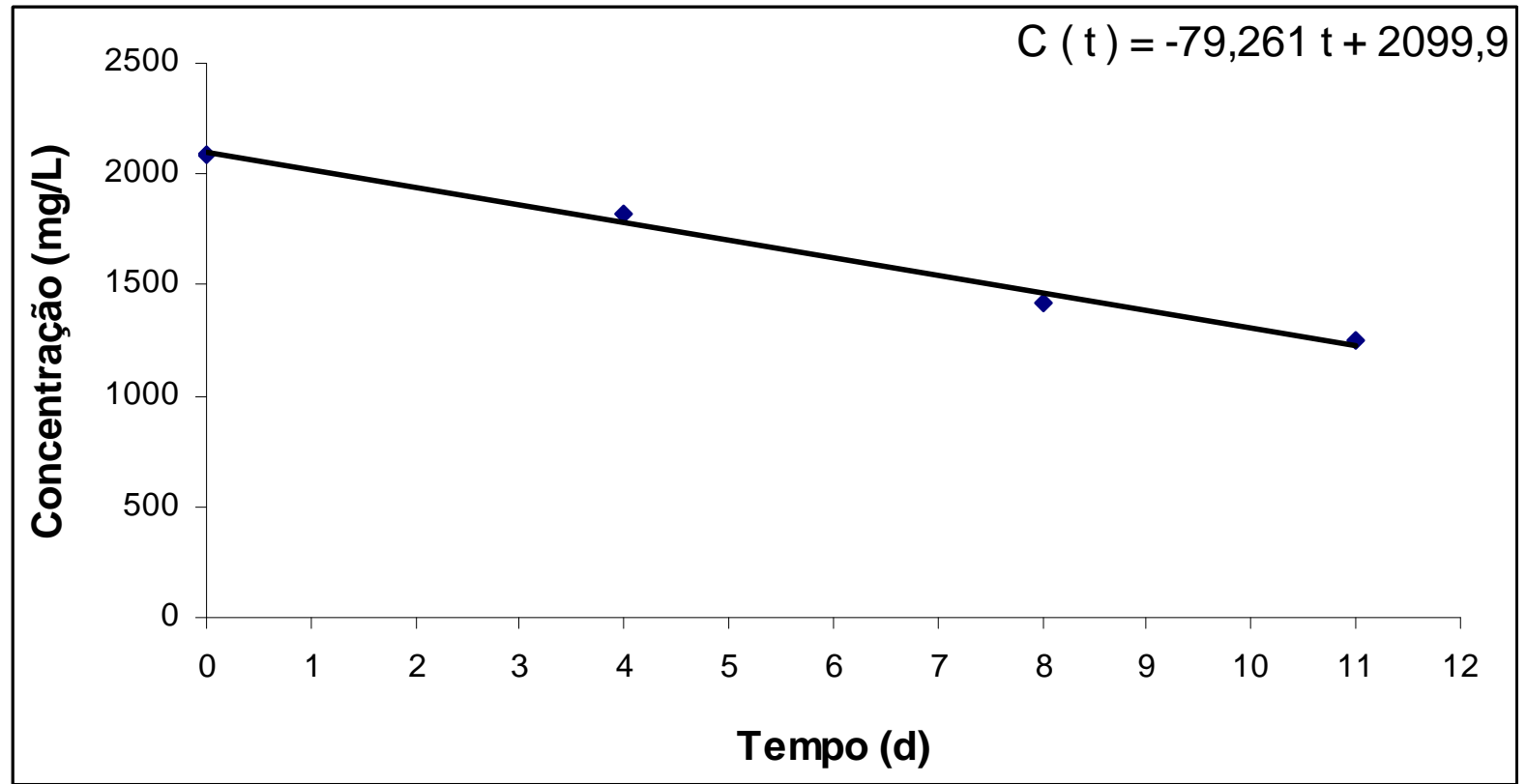

Figura 35 - Concentrações médias de N-NH3 durante os ciclos de "Stripping" - Aterro São João. 


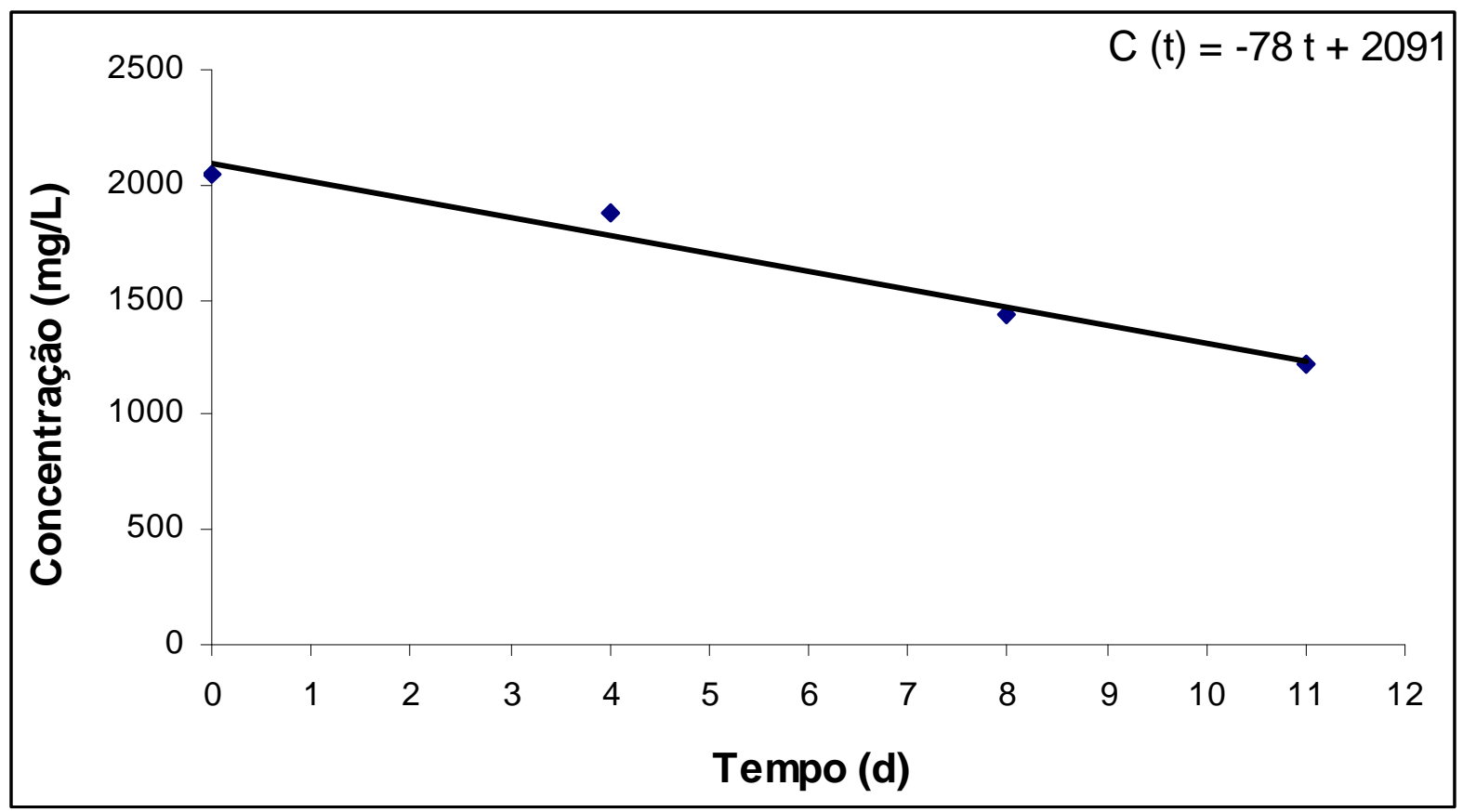

Figura 36 - Concentrações médias de $\mathrm{N}-\mathrm{NH}_{3}$ durante os ciclos de "stripping" - Aterro Bandeirantes

\subsubsection{Concentração do nitrogênio amoniacal no final do "stripping" igual a aproximadamente $900 \mathrm{mg} / \mathrm{L}$.}

Paralelamente aos 20 ciclos executados com o sistema R-2, foram executados 20 ciclos de "stripping" utilizando o sistema COL-1. É importante salientar que os ciclos do sistema COL-1 eram realizados em paralelo com os do sistema $\mathrm{R}-2$, ou seja, foi utilizado o mesmo lixiviado para iniciar o ciclo dos dois sistemas.

As figuras 38 e 39 demonstram o perfil de variação das concentrações de DQO referente aos 8 primeiros ciclos de "stripping", já as figuras 40, 41 e 42 demonstram a variação temporal das concentrações de DQO e COT dos 12 últimos ciclos de "stripping". Os ciclos foram seqüenciais por isso, as figuras trazem os dados de 4 em 4 ciclos.

Já a tabela 13 traz as características físico-químicas do lixiviado durante todos os ciclos de "stripping" da fase 2 utilizando o sistema COL-1. 


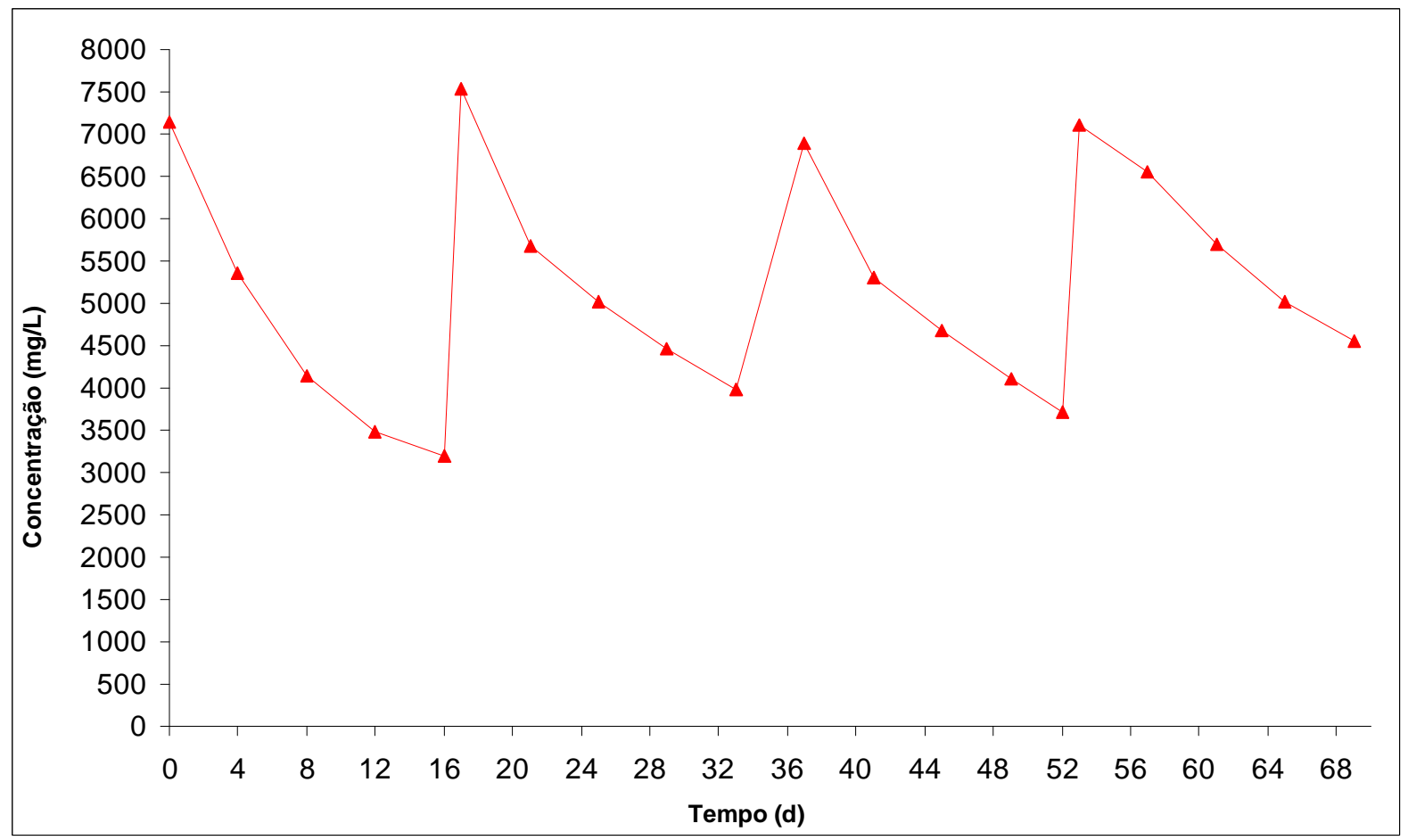

Figura 37 - Perfis temporais das concentrações de DQO dos 4 primeiros ciclos de "stripping" do lixiviado bruto (sistema COL-1).

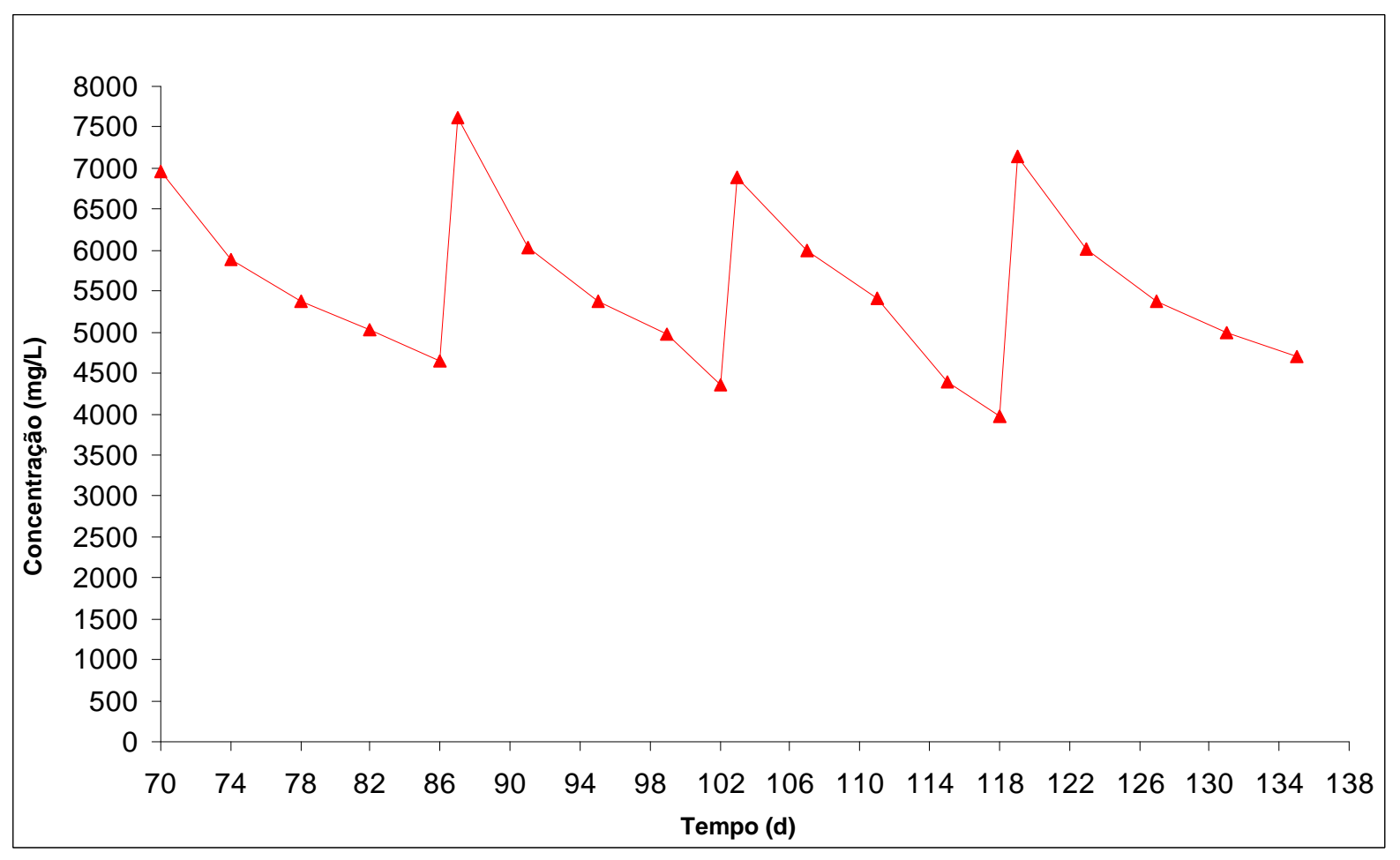

Figura 38 - Perfis temporais das concentrações de DQO dos 4 ciclos seguintes de "stripping" do lixiviado bruto (sistema COL-1). 


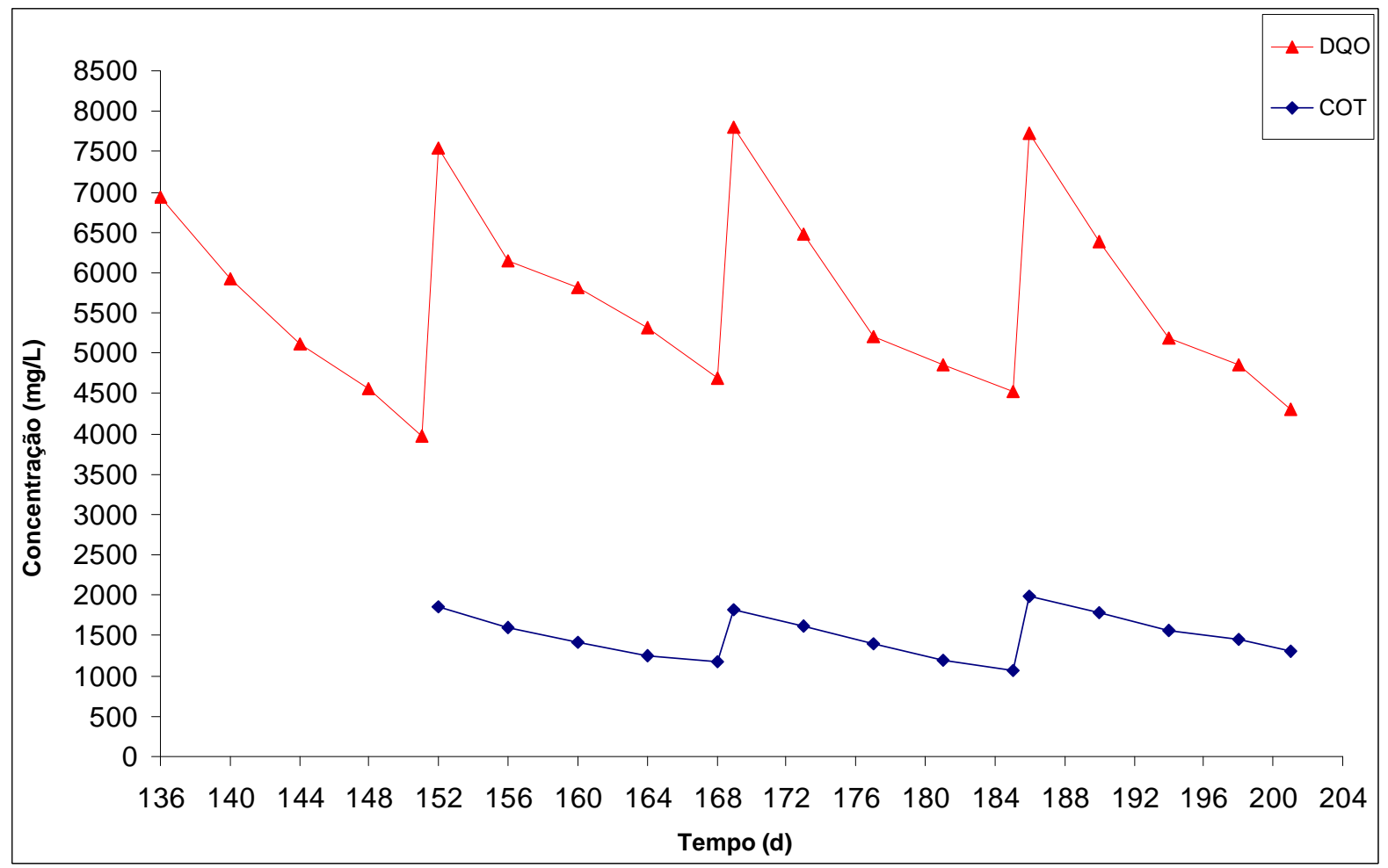

Figura 39 - Perfis temporais das concentrações de DQO e COT dos 4 ciclos seguintes de "stripping" do lixiviado bruto (sistema COL-1).

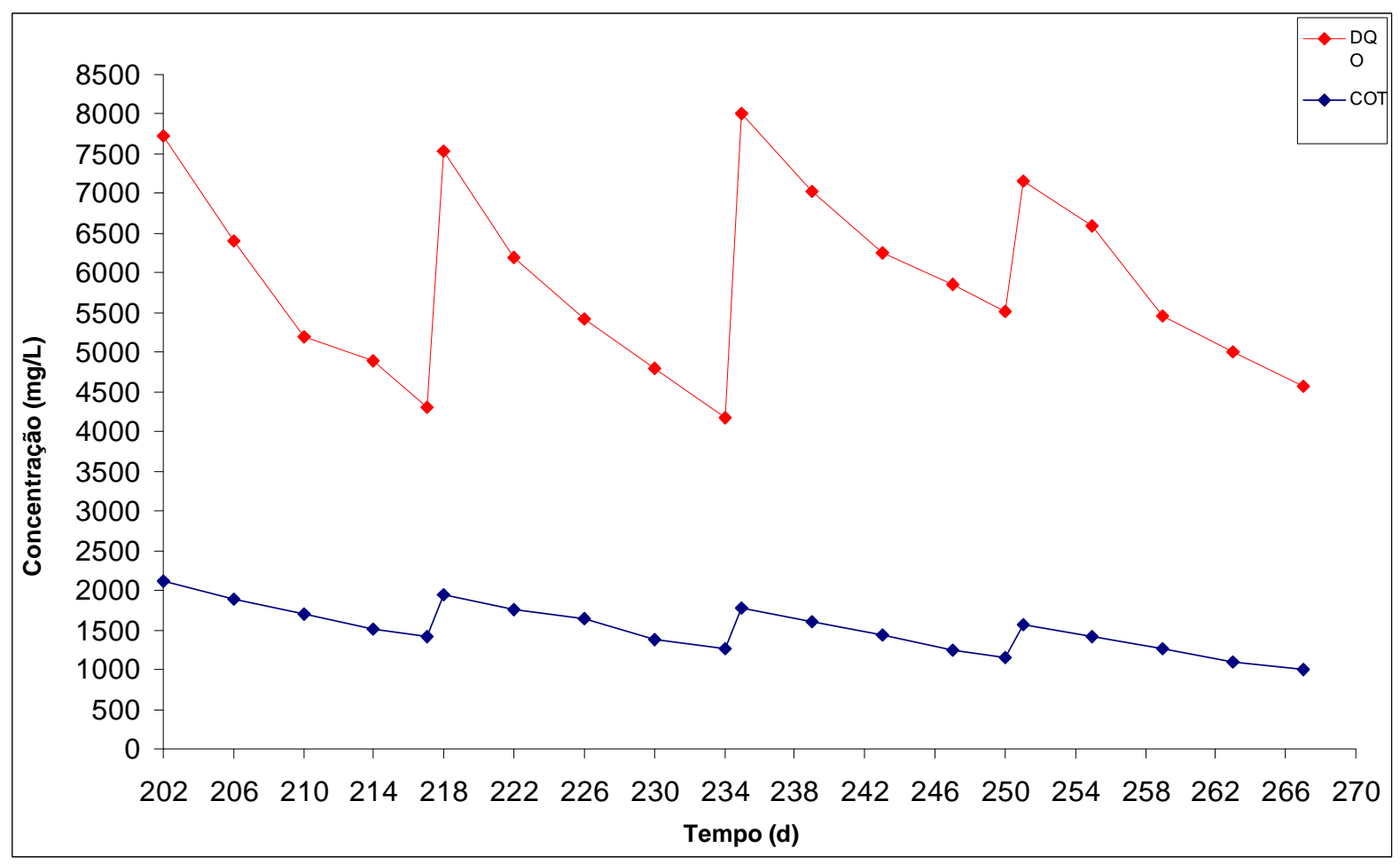

Figura 40 - Perfis temporais das concentrações de DQO e COT dos 4 ciclos seguintes de "stripping" do lixiviado bruto (COL-1). 


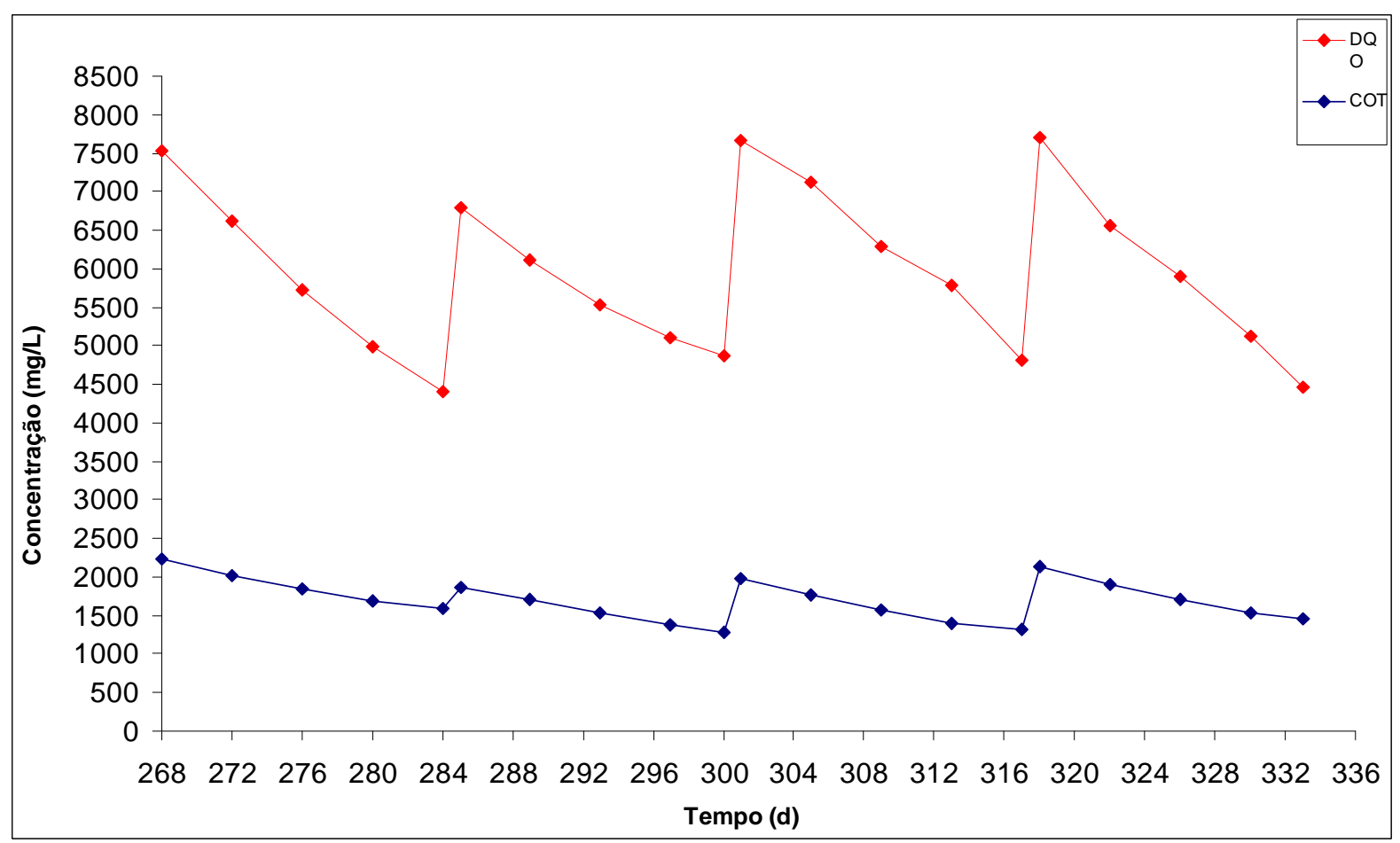

Figura 41 - Perfis temporais das concentrações de DQO e COT dos 4 últimos ciclos de "stripping" do lixiviado bruto (sistema COL-1).

Tabela 13 - Características físico-químicas do lixiviado durantes os ciclos de "stripping"

\begin{tabular}{|c|c|c|c|c|c|c|c|c|c|c|c|}
\hline Ciclo & $\begin{array}{l}\text { Tempo } \\
\text { (d) }\end{array}$ & $\begin{array}{l}\text { Duração } \\
\text { do ciclo } \\
\text { (d) }\end{array}$ & $\begin{array}{c}\mathrm{DBO} \\
(\mathrm{mg} / \mathrm{l})\end{array}$ & $\begin{array}{c}\text { DQO } \\
(\mathrm{mg} / \mathrm{l})\end{array}$ & $\begin{array}{c}\mathrm{N}- \\
\mathrm{NH}_{3} \\
(\mathrm{mg} / \mathrm{l})\end{array}$ & $\begin{array}{c}\text { Remoção } \\
\text { de DBO } \\
(\%)\end{array}$ & $\begin{array}{c}\text { COT } \\
(\mathrm{mg} / \mathrm{L})\end{array}$ & $\mathrm{pH}$ & $\begin{array}{c}\text { Alcalinidade } \\
\left(\mathrm{mg}^{2}\right. \\
\left.\mathrm{CaCO}_{3} / \mathrm{L}\right)\end{array}$ & $\begin{array}{c}\mathrm{ST} \\
(\mathrm{mg} / \mathrm{L} \\
)\end{array}$ & $\begin{array}{c}\mathrm{SSV}(\mathrm{mg} \\
/ \mathrm{L})\end{array}$ \\
\hline \multirow{5}{*}{1} & 0,0 & & 1900 & 7150 & 2200 & & - & 8,1 & 9860 & 18350 & 110 \\
\hline & 4,0 & & & 5360 & 1700 & & & & & & \\
\hline & 8,0 & & & 4150 & 1360 & & & & & & \\
\hline & 12,0 & & & 3480 & 1050 & & & & & & \\
\hline & 16,0 & 16 & 630 & 3200 & 915 & 66,8 & - & 8,8 & 5890 & 19420 & 220,0 \\
\hline \multirow{5}{*}{2} & 17,0 & & 2050 & 7530 & 2250 & & - & 8,3 & 11550 & 18400 & 90,0 \\
\hline & 21,0 & & & 5680 & 1930 & & & & & & \\
\hline & 25,0 & & & 5020 & 1590 & & & & & & \\
\hline & 29,0 & & & 4470 & 1110 & & & & & & \\
\hline & 33,0 & 16 & 710 & 3980 & 930 & 65,4 & - & 8,9 & 6050 & 20310 & 200,0 \\
\hline \multirow{5}{*}{3} & 37,0 & & 2100 & 6890 & 2380 & & - & 8,2 & 11200 & 17300 & 100 \\
\hline & 41,0 & & & 5310 & 1720 & & & & & & \\
\hline & 45,0 & & & 4680 & 1380 & & & & & & \\
\hline & 49,0 & & & 4100 & 1060 & & & & & & \\
\hline & 52,0 & 16 & 700 & 3720 & 910 & 66,7 & - & 8,9 & 6230 & 18840 & 235 \\
\hline \multirow{5}{*}{4} & 53,0 & & 1960 & 7110 & 2250 & & - & 7,9 & 10100 & 19340 & 75,0 \\
\hline & 57,0 & & & 6550 & 1700 & & & & & & \\
\hline & 61,0 & & & 5700 & 1280 & & & & & & \\
\hline & 65,0 & & & 5010 & 1190 & & & & & & \\
\hline & 69,0 & 16 & 780 & 4550 & 930 & 60,2 & - & 8,7 & 6090 & 20370 & 220,0 \\
\hline
\end{tabular}




\begin{tabular}{|c|c|c|c|c|c|c|c|c|c|c|c|}
\hline Ciclo & $\begin{array}{l}\text { Tempo } \\
\text { (d) }\end{array}$ & $\begin{array}{l}\text { Duração } \\
\text { do ciclo } \\
\text { (d) }\end{array}$ & $\begin{array}{c}\mathrm{DBO} \\
(\mathrm{mg} / \mathrm{l})\end{array}$ & $\begin{array}{c}\mathrm{DQO} \\
(\mathrm{mg} / \mathrm{l})\end{array}$ & $\begin{array}{c}\mathrm{N}- \\
\mathrm{NH}_{3} \\
(\mathrm{mg} / \mathrm{l})\end{array}$ & $\begin{array}{c}\text { Remoção } \\
\text { de DBO } \\
(\%)\end{array}$ & $\begin{array}{c}\mathrm{COT} \\
(\mathrm{mg} / \mathrm{L})\end{array}$ & $\mathrm{pH}$ & $\begin{array}{c}\text { Alcalinidade } \\
\left(\mathrm{mg}^{2}\right. \\
\left.\mathrm{CaCO}_{3} / \mathrm{L}\right)\end{array}$ & $\begin{array}{c}\mathrm{ST} \\
(\mathrm{mg} / \mathrm{L} \\
)\end{array}$ & $\begin{array}{c}\mathrm{SSV}(\mathrm{mg} \\
/ \mathrm{L})\end{array}$ \\
\hline \multirow{5}{*}{5} & 70,0 & & 1980 & 6960 & 2180 & & - & 8,3 & 11230 & 18090 & 100 \\
\hline & 74,0 & & & 5890 & 1650 & & & & & & \\
\hline & 78,0 & & & 5370 & 1410 & & & & & & \\
\hline & 82,0 & & & 5030 & 1150 & & & & & & \\
\hline & 86,0 & 16 & 850 & 4650 & 900 & 57,1 & - & 8,9 & 6670 & 19880 & 260 \\
\hline \multirow{5}{*}{6} & 87,0 & & 2480 & 7610 & 2100 & & - & 8,1 & 10880 & 14350 & 110,0 \\
\hline & 91,0 & & & 6030 & 1690 & & & & & & \\
\hline & 95,0 & & & 5380 & 1230 & & & & & & \\
\hline & 99,0 & & & 4970 & 1190 & & & & & & \\
\hline & 102,0 & 16 & 720 & 4350 & 910 & 71,0 & - & 8,8 & 5090 & 16110 & 180,0 \\
\hline \multirow{5}{*}{7} & 103,0 & & 1870 & 6890 & 2230 & & - & 8,0 & 10560 & 18760 & 70 \\
\hline & 107,0 & & & 6000 & 1760 & & & & & & \\
\hline & 111,0 & & & 5410 & 1390 & & & & & & \\
\hline & 115,0 & & & 4400 & 1180 & & & & & & \\
\hline & 118,0 & 16 & 680 & 3980 & 910 & 63,6 & - & 8,8 & 6545 & 19130 & 200 \\
\hline \multirow{5}{*}{8} & 119,0 & & 2020 & 7140 & 2260 & & - & 8,3 & 11150 & 17680 & 65,0 \\
\hline & 123,0 & & & 6010 & 1770 & & & & & & \\
\hline & 127,0 & & & 5380 & 1390 & & & & & & \\
\hline & 131,0 & & & 5000 & 1140 & & & & & & \\
\hline & 135,0 & 16 & 710 & 4710 & 920 & 64,9 & - & 9,0 & 6300 & 19330 & 210,0 \\
\hline \multirow{5}{*}{9} & 136,0 & & 1910 & 6930 & 2180 & & - & 7,9 & 9720 & 18340 & 120 \\
\hline & 140,0 & & & 5930 & 1810 & & & & & & \\
\hline & 144,0 & & & 5110 & 1290 & & & & & & \\
\hline & 148,0 & & & 4560 & 1110 & & & & & & \\
\hline & 151,0 & 16 & 670 & 3980 & 910 & 64,9 & - & 8,8 & 5020 & 19120 & 230 \\
\hline \multirow{5}{*}{10} & 152,0 & & 2100 & 7540 & 2150 & & 1850 & 8,2 & 10640 & 15640 & 110,0 \\
\hline & 156,0 & & & 6150 & 1620 & & 1600 & & & & \\
\hline & 160,0 & & & 5820 & 1570 & & 1410 & & & & \\
\hline & 164,0 & & & 5320 & 1150 & & 1260 & & & & \\
\hline & 168,0 & 16 & 810 & 4700 & 930 & 61,4 & 1180 & 8,9 & 6890 & 16500 & 210,0 \\
\hline \multirow{5}{*}{11} & 169,0 & & 2000 & 7800 & 2130 & & 1830 & 8,0 & 11620 & 21340 & 130 \\
\hline & 173,0 & & & 6480 & 1630 & & 1610 & & & & \\
\hline & 177,0 & & & 5210 & 1280 & & 1390 & & & & \\
\hline & 181,0 & & & 4850 & 1020 & & 1190 & & & & \\
\hline & 185,0 & 16 & 730 & 4530 & 910 & 63,5 & 1070 & 8,8 & 6570 & 21800 & 265 \\
\hline \multirow{5}{*}{12} & 186,0 & & 2120 & 7720 & 2200 & & 1980 & 7,9 & 10120 & 17600 & 80,0 \\
\hline & 190,0 & & & 6390 & 1860 & & 1780 & & & & \\
\hline & 194,0 & & & 5180 & 1370 & & 1570 & & & & \\
\hline & 198,0 & & & 4860 & 1130 & & 1450 & & & & \\
\hline & 201,0 & 16 & 780 & 4300 & 910 & 63,2 & 1310 & 8,6 & 7110 & 18750 & 200,0 \\
\hline \multirow{5}{*}{13} & 202,0 & & 1910 & 7830 & 2150 & & 2110 & 8,0 & 9875 & 17890 & 80 \\
\hline & 206,0 & & & 6410 & 1750 & & 1880 & & & & \\
\hline & 210,0 & & & 5200 & 1300 & & 1700 & & & & \\
\hline & 214,0 & & & 4890 & 1080 & & 1520 & & & & \\
\hline & 217,0 & 16 & 810 & 4310 & 920 & 57,6 & 1410 & 8,7 & 6350 & 19420 & 250 \\
\hline
\end{tabular}




\begin{tabular}{|c|c|c|c|c|c|c|c|c|c|c|c|}
\hline Ciclo & $\begin{array}{l}\text { Tempo } \\
\text { (d) }\end{array}$ & $\begin{array}{l}\text { Duração } \\
\text { do ciclo } \\
\text { (d) }\end{array}$ & $\begin{array}{c}\mathrm{DBO} \\
(\mathrm{mg} / \mathrm{l})\end{array}$ & $\begin{array}{c}\mathrm{DQO} \\
(\mathrm{mg} / \mathrm{l})\end{array}$ & $\begin{array}{c}\mathrm{N}- \\
\mathrm{NH}_{3} \\
(\mathrm{mg} / \mathrm{l})\end{array}$ & $\begin{array}{c}\text { Remoção } \\
\text { de DBO } \\
(\%)\end{array}$ & $\begin{array}{c}\mathrm{COT} \\
(\mathrm{mg} / \mathrm{L})\end{array}$ & $\mathrm{pH}$ & $\begin{array}{c}\text { Alcalinidade } \\
\left(\mathrm{mg}_{3}\right. \\
\left.\mathrm{CaCO}_{3} / \mathrm{L}\right)\end{array}$ & $\begin{array}{c}\mathrm{ST} \\
(\mathrm{mg} / \mathrm{L} \\
)\end{array}$ & $\begin{array}{c}\mathrm{SSV}(\mathrm{mg} \\
\quad / \mathrm{L})\end{array}$ \\
\hline \multirow{5}{*}{14} & 218,0 & & 2100 & 7530 & 2200 & & 1940 & 8,1 & 12440 & 16780 & 110,0 \\
\hline & 222,0 & & & 6200 & 1660 & & 1760 & & & & \\
\hline & 226,0 & & & 5420 & 1310 & & 1650 & & & & \\
\hline & 230,0 & & & 4800 & 1120 & & 1380 & & & & \\
\hline & 234,0 & 16 & 820 & 4180 & 930 & 61,0 & 1260 & 8,9 & 7300 & 17230 & 230,0 \\
\hline \multirow{5}{*}{15} & 235,0 & & 2500 & 8000 & 2300 & & 1780 & 8,1 & 11560 & 19340 & 70 \\
\hline & 239,0 & & & 7020 & 1880 & & 1600 & & & & \\
\hline & 243,0 & & & 6260 & 1390 & & 1440 & & & & \\
\hline & 247,0 & & & 5850 & 1130 & & 1240 & & & & \\
\hline & 250,0 & 16 & 900 & 5510 & 910 & 64,0 & 1150 & 8,8 & 6340 & 21780 & 190 \\
\hline \multirow{5}{*}{16} & 251,0 & & 1950 & 7150 & 2130 & & 1560 & 8,0 & 9890 & 18670 & 40,0 \\
\hline & 255,0 & & & 6600 & 1810 & & 1410 & & & & \\
\hline & 259,0 & & & 5450 & 1350 & & 1260 & & & & \\
\hline & 263,0 & & & 5010 & 1100 & & 1100 & & & & \\
\hline & 267,0 & 16 & 610 & 4580 & 920 & 68,7 & 1010 & 8,9 & 5500 & 19120 & 180,0 \\
\hline \multirow{5}{*}{17} & 268,0 & & 2210 & 7520 & 2200 & & 2230 & 8,1 & 10140 & 19540 & 110 \\
\hline & 272,0 & & & 6610 & 1730 & & 2020 & & & & \\
\hline & 276,0 & & & 5720 & 1210 & & 1840 & & & & \\
\hline & 280,0 & & & 4990 & 1040 & & 1690 & & & & \\
\hline & 284,0 & 16 & 790 & 4410 & 930 & 64,3 & 1600 & 8,7 & 6430 & 21690 & 215 \\
\hline \multirow{5}{*}{18} & 285,0 & & 1980 & 6800 & 2020 & & 1870 & 7,9 & 10900 & 19320 & 90,0 \\
\hline & 289,0 & & & 6120 & 1600 & & 1700 & & & & \\
\hline & 293,0 & & & 5540 & 1380 & & 1540 & & & & \\
\hline & 297,0 & & & 5100 & 1090 & & 1370 & & & & \\
\hline & 300,0 & 16 & 740 & 4870 & 910 & 62,6 & 1290 & 8,8 & 7120 & 21100 & 240,0 \\
\hline \multirow{5}{*}{19} & 301,0 & & 2260 & 7670 & 1950 & & 1980 & 8,2 & 11340 & 15690 & 85 \\
\hline & 305,0 & & & 7120 & 1670 & & 1760 & & & & \\
\hline & 309,0 & & & 6290 & 1350 & & 1580 & & & & \\
\hline & 313,0 & & & 5790 & 1140 & & 1390 & & & & \\
\hline & 317,0 & 16 & 875 & 4810 & 930 & 61,3 & 1310 & 9,0 & 6890 & 16300 & 195 \\
\hline \multirow{5}{*}{20} & 318,0 & & 1800 & 7700 & 2210 & & 2140 & 8,0 & 9650 & 20670 & 110,0 \\
\hline & 322,0 & & & 6560 & 1810 & & 1900 & & & & \\
\hline & 326,0 & & & 5900 & 1380 & & 1710 & & & & \\
\hline & 330,0 & & & 5130 & 1090 & & 1540 & & & & \\
\hline & 333,0 & 16 & 690 & 4470 & 920 & 61,7 & 1460 & 8,8 & 5900 & 21990 & 230,0 \\
\hline
\end{tabular}

Observando-se as figuras 38 a 42 nota-se que assim como no "stripping" por agitação mecânica, o sistema de "stripping" por aeração proporcionou uma queda na concentração de DQO e COT. Em comparação ao sistema R-2 a diminuição da $\mathrm{DQO}, \mathrm{DBO}$ e COT da massa líquida no sistema COL-1 foi maior. Enquanto que no sistema R-2 a remoção média da concentração de DBO e DQO foi de 58 e $38 \%$ 
respectivamente, a remoção da DBO e DQO no sistema COL-1 foi de 63,5 e 40,4\% respectivamente. Já a eficiência média da remoção de COT foi de 34\%.

O fato de se introduzir ar no sistema pode ter favorecido o crescimento de biomassa no sistema COL-1 aumentando assim, a eficiência na remoção de matéria orgânica bem como a maior volatilização de compostos orgânicos voláteis.

Durante os ciclos de "stripping" houve um aumento no $\mathrm{pH}$ e uma diminuição na concentração de alcalinidade. A figura 43 demonstra o perfil do $\mathrm{pH}$ durante o primeiro ciclo de "stripping"; já a figura 44 traz o perfil de concentração da alcalinidade durante o mesmo ciclo.

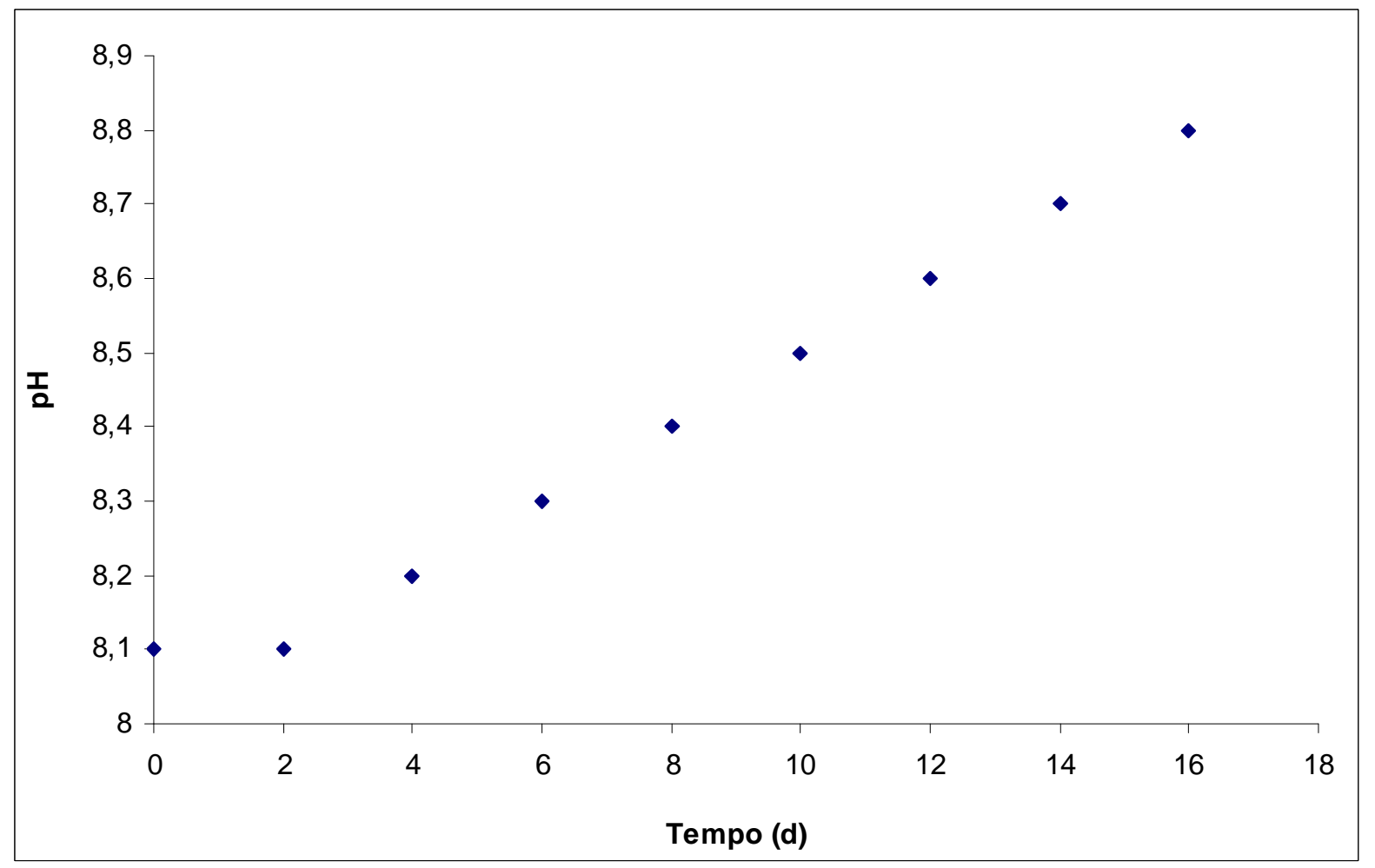

Figura 42 - Variação temporal do pH do lixiviado durante o primeiro ciclo de "stripping" (sistema COL-1/Fase 2). 


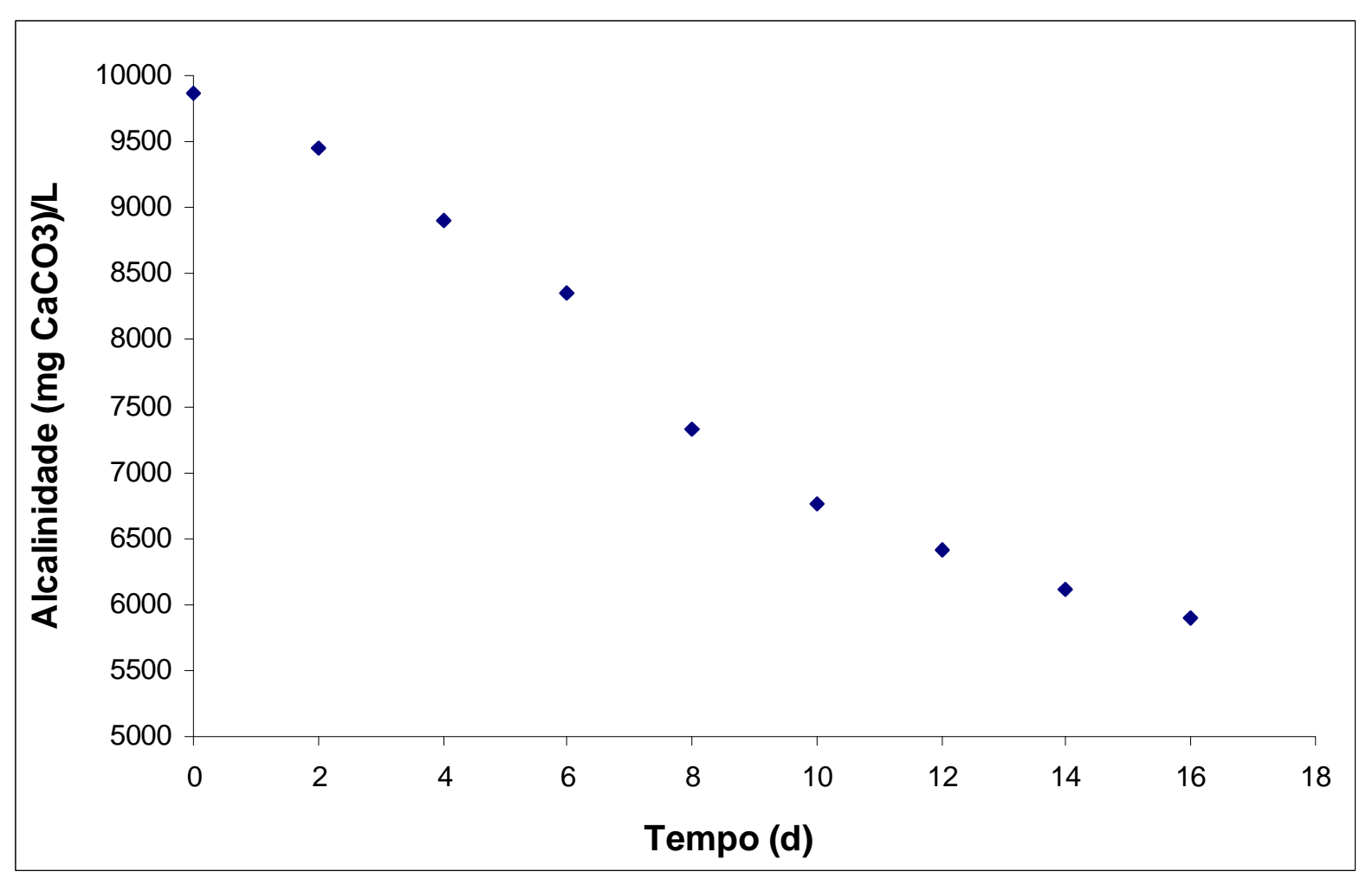

Figura 43 - Variação temporal da concentração de alcalinidade do lixiviado durante o primeiro ciclo de "stripping" (sistema COL-1/Fase 2).

O decaimento do nitrogênio amoniacal durante os ciclos de "stripping" utilizando o sistema COL - 1 apresentou um comportamento semelhante ao observado no sistema R-2. Através da figura 45 pode-se observar a distribuição da concentração de $\mathrm{N}-\mathrm{NH}_{3}$ durante os 20 ciclos de "stripping" utilizando-se o sistema COL-1. Já a figura 36 traz o perfil das concentrações médias de $\mathrm{N}-\mathrm{NH}_{3}$ durante os 20 ciclos de "stripping".

Pode-se observar através da figura 45 que a distribuição da concentração de $\mathrm{N}-\mathrm{NH}_{3}$ durante os 20 ciclos de "stripping" pode ser representado por uma reta, o que significa que as reações ocorridas podem ser representadas por uma equação de ordem zero.

O tempo médio de "stripping" no sistema por aeração foi de 16 dias. A taxa média de transferência de $\mathrm{N}-\mathrm{NH}_{3}$ durante o "stripping" foi de 78,9 mg N-NH$/$ L.dia. 


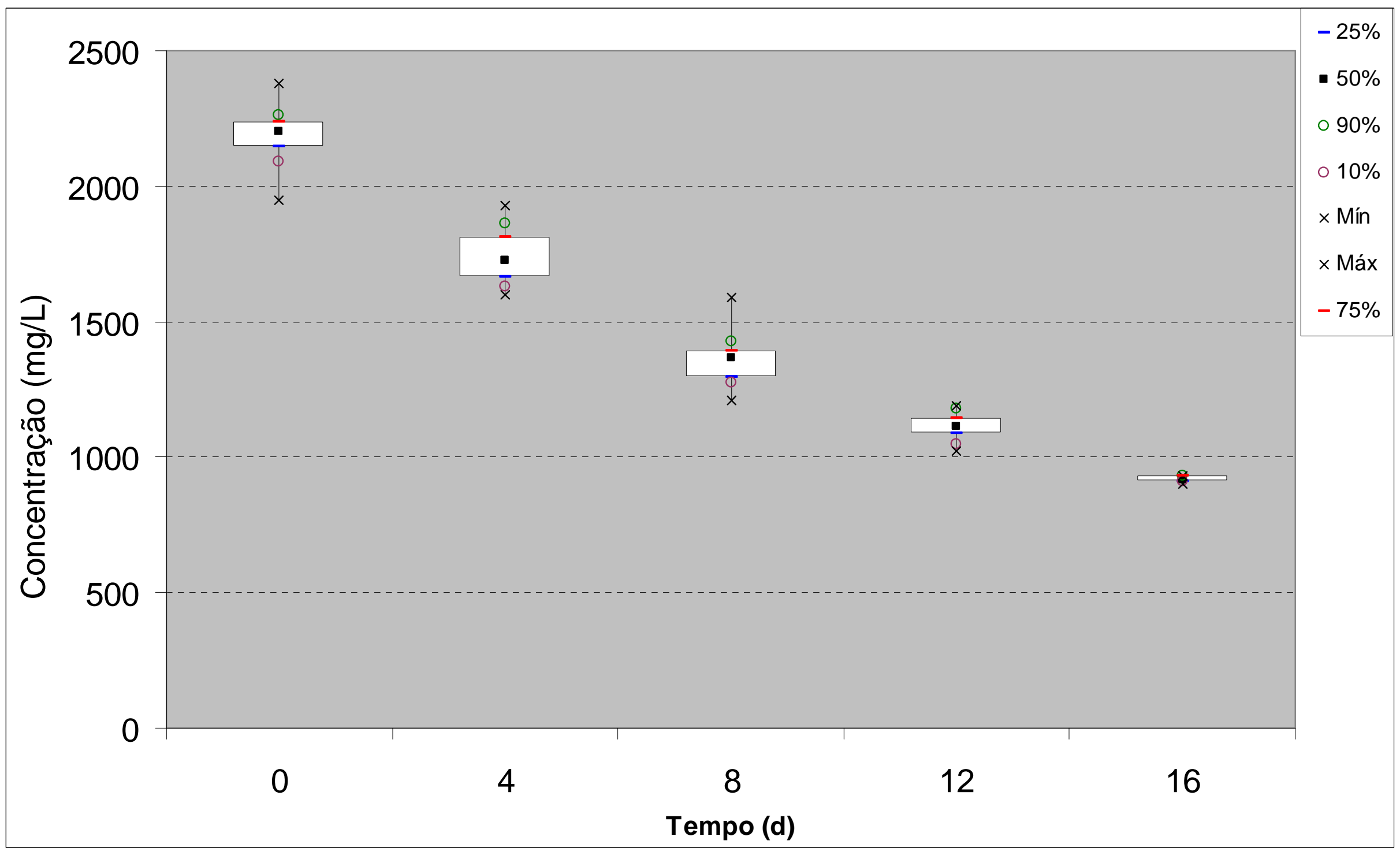

Figura 44 - Perfis das concentrações de $\mathrm{N}-\mathrm{NH}_{3}$ durante os 20 ciclos de "stripping". 


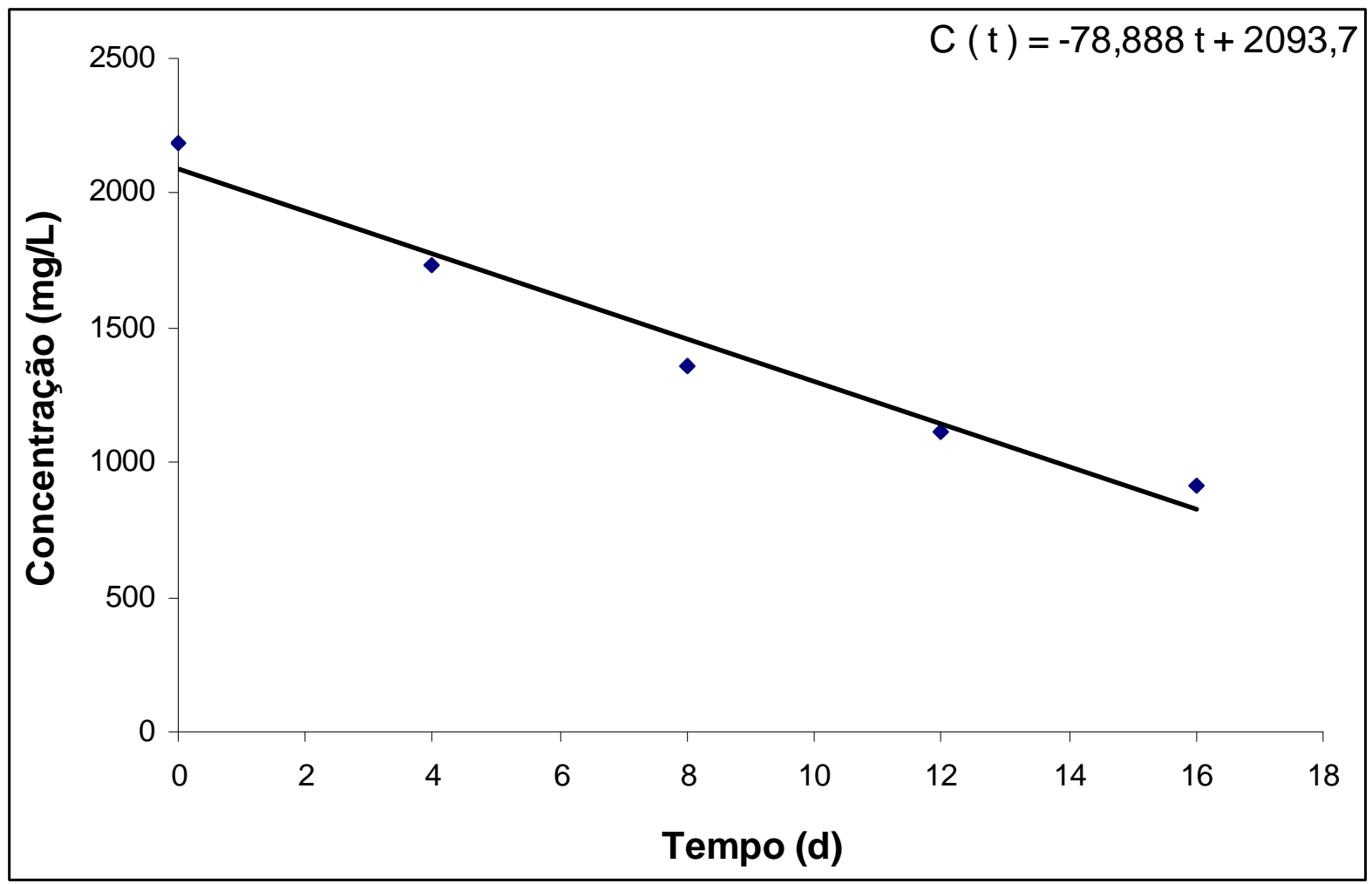

Figura 45 - Concentrações médias de $\mathrm{N}-\mathrm{NH}_{3}$ durante os ciclos de "Stripping" - Sistema COL-1. 


\subsection{SISTEMA EM BATELADAS SEQÜENCIAIS (R-1)}

\subsubsection{FASE 01 - ALIMENTAÇÃO DO SISTEMA UTILIZANDO LIXIVIADO BRUTO - PARTIDA DO SISTEMA}

Além da partida do sistema, o primeiro ciclo de tratamento da pesquisa tinha como objetivo determinar as condições e parâmetros necessários para a inibição do processo de nitratação (acúmulo de nitrito). A intenção inicial nesta fase era que não houvesse a necessidade de controlar nenhum parâmetro ambiental do reator R-1, já que este ciclo tinha um caráter exploratório. A única preocupação neste primeiro ciclo era determinar os tempos de cada etapa do mesmo. O controle do inicio e do final de cada etapa foi feito como descrito no item 4.4.1.4.

A figura 47 demonstra a variação das concentrações de nitrito, nitrato, $\mathrm{N}-\mathrm{NH}_{3}$ e DBO durante os primeiro ciclo de "stripping".

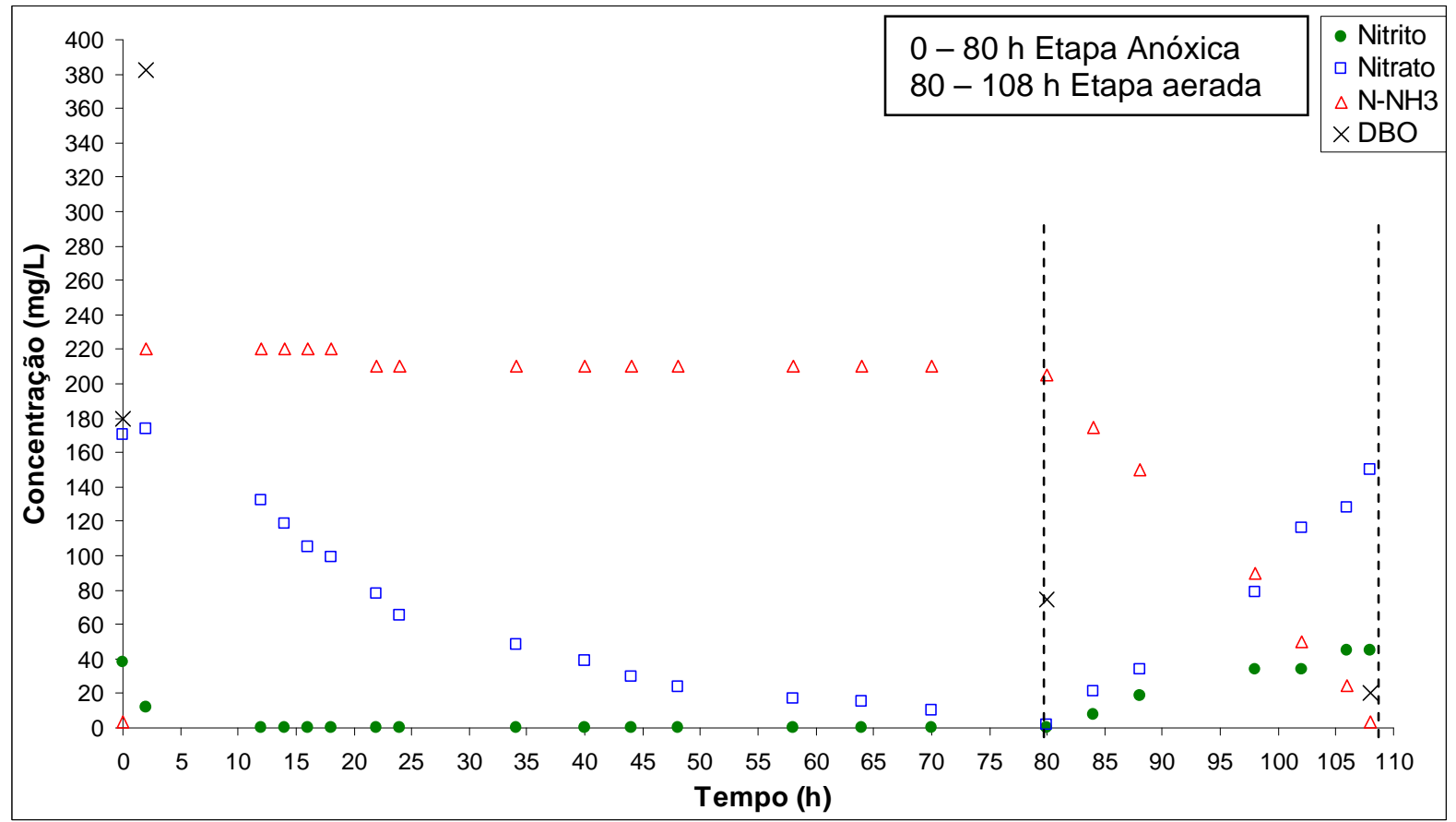

Figura 46 - Perfis temporais das concentrações de $\mathrm{DBO}, \mathrm{N}-\mathrm{NO}_{2}^{-}, \mathrm{N}-\mathrm{NO}_{3}^{-}$e N-NH${ }_{3}+$ durante o primeiro ciclo de tratamento do reator R-1/Fase 1 - Aterro São João. 
Através da figura 47 pode-se observar que no início do tratamento houve uma maior formação de nitrato do que de nitrito, ou seja, a inibição da nitratação não foi eficiente. Durante o período aerado o consumo de alcalinidade fez com que o pH da massa líquida decaísse muito obrigando assim, a adição de alcalinizante ao sistema $(50 \mathrm{ml} \mathrm{NaOH} 1 \mathrm{~N})$ para manter $\mathrm{o} \mathrm{pH}$ do sistema próximo a 8,3. Mesmo com a manutenção do pH o acúmulo de nitrito não foi favorecido; este fato pode ter sido causado pela não aclimatação dos microrganismos as condições operacionais necessárias a inibição da nitratação já que, este era o primeiro ciclo de tratamento.

A tabela 14 traz as características físico-químicas e taxas referentes ao primeiro ciclo de tratamento.

Nota-se através da figura 47 que mesmo no início da etapa anóxica, a concentração de nitrato no reator continuou subindo, ou seja, uma parcela do nitrito formado durante a fase aerada foi convertido em nitrato e posteriormente reduzido a nitrogênio gasoso. Este fato atesta a dificuldade em se manter o nitrogênio oxidado na forma de nitrito, que é mais instável.

Tabela 14 - Características físico-químicas e taxas do primeiro ciclo de tratamento utilizando o sistema R-1 (primeira fase - aterro São João)

Inicio da etapa anóxica (após alimentação)

\begin{tabular}{|c|c|c|c|c|c|c|c|c|c|}
\hline Ciclo pH & $\begin{array}{c}\text { Alcalinidade } \\
\text { Total }(\mathrm{mg} / \mathrm{L} \\
\left.\mathrm{CaCO}_{3}\right)\end{array}$ & $\begin{array}{c}\text { SSV } \\
(\mathrm{mg} / \mathrm{L})\end{array}$ & $\begin{array}{c}\mathrm{DBO} \\
\text { (mg/L) }\end{array}$ & $\begin{array}{c}\text { Relação } \\
\mathrm{DBO}_{\text {removidal }} \\
\text { Nitrito- } \\
\text { Nitrato } \\
(\mathrm{Kg} \mathrm{DBO} \mathrm{DB} / \mathrm{Kg} \\
\left.\mathrm{NO}_{3}^{-}, \mathrm{NO}_{2}^{-}\right)\end{array}$ & $\begin{array}{l}\text { Nitrito } \\
\text { (mg/L) }\end{array}$ & $\begin{array}{l}\text { Nitrato } \\
\text { (mg/L) }\end{array}$ & $\begin{array}{l}\mathrm{N}-\mathrm{NH}_{3} \\
(\mathrm{mg} / \mathrm{L})\end{array}$ & $\begin{array}{c}\text { Eficiência } \\
\text { na remoção } \\
\text { de DBO do } \\
\text { ciclo (\%) }\end{array}$ & $\begin{array}{l}\text { Temperatura } \\
\text { média do } \\
\text { ciclo }\left({ }^{0} \mathrm{C}\right)\end{array}$ \\
\hline
\end{tabular}

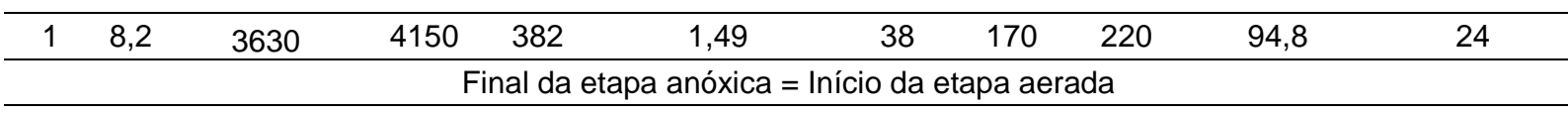

\begin{tabular}{|c|c|c|c|c|c|c|c|c|c|c|}
\hline Ciclo & $\mathrm{pH}$ & $\begin{array}{c}\text { Alcalinidade } \\
\text { Total }(\mathrm{mg} / \mathrm{L} \\
\left.\mathrm{CaCO}_{3}\right)\end{array}$ & $\begin{array}{c}\text { SSV } \\
(\mathrm{mg} / \mathrm{L})\end{array}$ & $\begin{array}{c}\text { DBO } \\
(\mathrm{mg} / \mathrm{L})\end{array}$ & $\begin{array}{c}\text { Taxa de } \\
\text { Desnitrificação } \\
\text { (Kg NO3-, NO2- } \\
\text { / Kg SSV.dia) }\end{array}$ & $\begin{array}{l}\text { Nitrito } \\
\text { (mg/L) }\end{array}$ & $\begin{array}{l}\text { Nitrato } \\
(\mathrm{mg} / \mathrm{L})\end{array}$ & $\begin{array}{l}\mathrm{N}-\mathrm{NH}_{3} \\
(\mathrm{mg} / \mathrm{L})\end{array}$ & $\begin{array}{l}\text { Tempo da } \\
\text { etapa }(\mathrm{h})\end{array}$ & $\begin{array}{c}\text { Eficiência na } \\
\text { remoção de } \\
\mathrm{N}-\mathrm{NO}_{2}^{-} / \mathrm{N}- \\
\mathrm{NO}_{3}^{-}(\%)\end{array}$ \\
\hline 1 & 8,6 & 3780 & 4170 & 75 & 0,0148 & 2 & 0 & 205 & 80 & 99,0 \\
\hline \multicolumn{11}{|c|}{ Fase Aerada } \\
\hline \multicolumn{11}{|c|}{ Final da etapa aerada } \\
\hline Ciclo & $\mathrm{pH}$ & $\begin{array}{l}\text { Alcalinidade } \\
\text { Total }(\mathrm{mg} / \mathrm{L} \\
\left.\mathrm{CaCO}_{3}\right)\end{array}$ & $\begin{array}{l}\text { SSV } \\
(\mathrm{mg} / \mathrm{L})\end{array}$ & $\begin{array}{c}\text { DBO } \\
\text { (mg/L) }\end{array}$ & $\begin{array}{l}\text { Tempo da } \\
\text { etapa }(\mathrm{h})\end{array}$ & $\begin{array}{l}\text { Nitrito } \\
\text { (mg/L) }\end{array}$ & $\begin{array}{l}\text { Nitrato } \\
(\mathrm{mg} / \mathrm{L})\end{array}$ & $\begin{array}{l}\mathrm{N}-\mathrm{NH}_{3} \\
(\mathrm{mg} / \mathrm{L})\end{array}$ & $\begin{array}{c}\text { Taxa de } \\
\text { Nitrificação } \\
\text { (Kg N-NH } / \\
\text { Kg } \\
\text { SSV.dia) }\end{array}$ & $\begin{array}{c}\text { Eficiência na } \\
\text { remoção de } \\
\mathrm{N}-\mathrm{NH}_{3}(\%)\end{array}$ \\
\hline 1 & 8,1 & 3420 & 4090 & 20 & 28 & 45,0 & 150 & 3 & 0,042 & 98,5 \\
\hline
\end{tabular}


Através dos dados apresentados na tabela 14 nota-se que o tempo da etapa anóxica foi relativamente longo sendo que, a taxa de desnitritação ficou em torno de 0,0148 $\mathrm{Kg}\left(\mathrm{NO}_{3}^{-}, \mathrm{NO}_{2}^{-}\right) / \mathrm{Kg} \mathrm{SSV}$.dia). Já a taxa de nitrificação foi de $0,042 \mathrm{Kg} \mathrm{N}-\mathrm{NH}_{3} / \mathrm{Kg}$ SSV.dia. Apesar do longo tempo da etapa anóxica e das baixas taxas de desnitrificação e nitrificação, a eficiência global de remoção de nitrogênio amoniacal foi alta ficando acima de $95 \%$.

A concentração de amônia livre no reator variou de $20,7 \mathrm{mg} / \mathrm{L}$ (inicio da etapa aerada) a $0,23 \mathrm{mg} / \mathrm{L}$ (final etapa aerada) para uma temperatura média no ciclo de 24 ${ }^{0} \mathrm{C}$. O cálculo da amônia livre foi feito de acordo com a formulação proposta por Anthonisen et al. (1976) (equação 12) o qual observou uma inibição das bactérias que oxidam nitrito quando a concentração de $\mathrm{N}^{-\mathrm{NH}_{3}}$ na massa líquida encontrava-se na faixa de 0,1 a 1,0 mg/L sendo assim, com os valores encontrados de Amônia livre durante o primeiro ciclo de "stripping" apontariam para um possível acúmulo de nitrito, porém na prática não foi o que ocorreu.

A figura 48 bem como a tabela 15 trazem as características físico-químicas e taxas determinadas durante o segundo ciclo do sistema R-1 alimentado com lixiviado do aterro Bandeirantes.

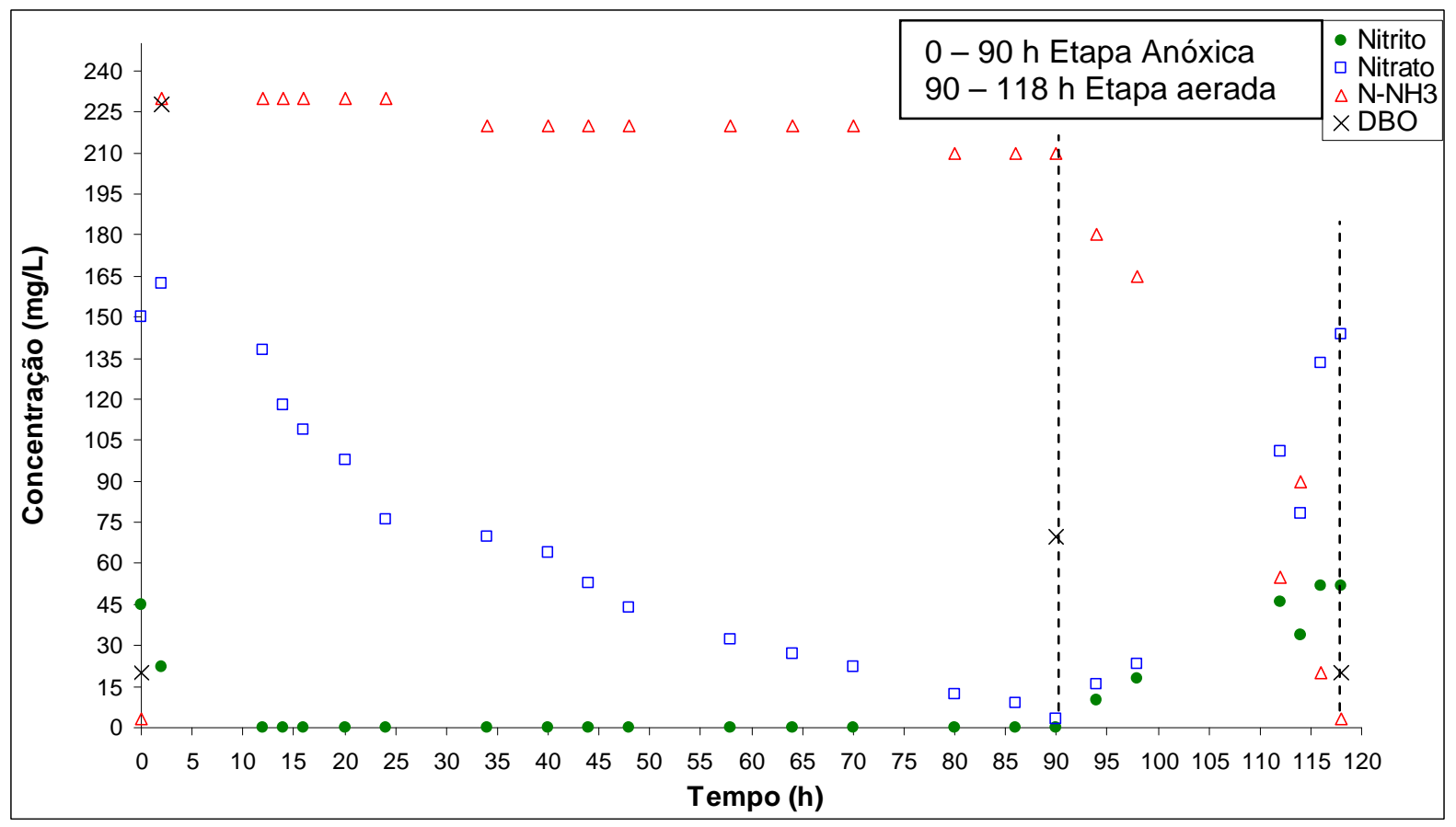

Figura 47 - Perfis temporais das concentrações de DBO, N-NO ${ }_{2}^{-}, \mathrm{N}-\mathrm{NO}_{3}{ }^{-}$e $\mathrm{N}-\mathrm{NH}_{3}+$ durante o segundo ciclo de tratamento do reator R-1/Fase 1 - Aterro Bandeirantes. 
Neste ciclo, assim como no anterior, o pH da massa líquida teve um decréscimo acentuado durante o período aerado sendo necessário a introdução de alcalinizante para a manutenção do pH a níveis próximos a 8,3. Segundo QUEIROZ (2006), a manipulação do $\mathrm{pH}$ a valores próximos a 8,3 foi importante para a manutenção da amônia livre no reator em concentrações favoráveis a inibição das bactérias oxidantes de nitrito.

Mesmo com a adição de alcalinizante o pH da massa líquida, em dados momentos da etapa aeróbia, decaia acentuadamente o que pode ter dificultado o acúmulo de nitrito.

Nesta etapa do ciclo a fase anóxica foi mais longa do que a do ciclo 1. Como o lixiviado do aterro Bandeirantes tem por característica uma baixa concentração de compostos recalcitrantes, a difícil assimilação destes compostos pelas bactérias redutoras de nitrito pode ter ocasionado o longo tempo da etapa anóxica.

Tabela 15 - Características físico-químicas e taxas do segundo ciclo de tratamento utilizando o sistema R-1 (primeira fase - aterro Bandeirantes)

\begin{tabular}{|c|c|c|c|c|c|c|c|c|c|c|}
\hline \multicolumn{11}{|c|}{ Fase Anóxica } \\
\hline \multicolumn{11}{|c|}{ Inicio da etapa anóxica (após alimentação) } \\
\hline Ciclo & $\mathrm{pH}$ & $\begin{array}{c}\text { Alcalinidade } \\
\text { Total }(\mathrm{mg} / \mathrm{L} \\
\left.\mathrm{CaCO}_{3}\right)\end{array}$ & $\begin{array}{c}\text { SSV } \\
(\mathrm{mg} / \mathrm{L})\end{array}$ & $\begin{array}{c}\mathrm{DBO} \\
(\mathrm{mg} / \mathrm{L})\end{array}$ & $\begin{array}{c}\text { Relação } \\
\text { DBO removida/ } \\
\text { Nitrito- } \\
\text { Nitratoremovido } \\
\left(\mathrm{Kg} \mathrm{DBO}^{-} \mathrm{Kg}\right. \\
\left.\mathrm{NO}_{3}^{-}, \mathrm{NO}_{2}^{-}\right)\end{array}$ & $\begin{array}{l}\text { Nitrito } \\
\text { (mg/L) }\end{array}$ & $\begin{array}{l}\text { Nitrato } \\
(\mathrm{mg} / \mathrm{L})\end{array}$ & $\begin{array}{l}\mathrm{N}-\mathrm{NH}_{3} \\
(\mathrm{mg} / \mathrm{L})\end{array}$ & $\begin{array}{c}\text { Eficiência } \\
\text { na } \\
\text { remoção } \\
\text { de DBO do } \\
\text { ciclo (\%) }\end{array}$ & $\begin{array}{c}\text { Temperatura } \\
\text { média do } \\
\text { ciclo }\left({ }^{0} \mathrm{C}\right)\end{array}$ \\
\hline 2 & 8,2 & 3450 & 3720 & 228 & 0,82 & 45 & 150 & 230 & 91,2 & 24 \\
\hline \multicolumn{11}{|c|}{ Final da etapa anóxica = Início da etapa aerada } \\
\hline Ciclo & $\mathrm{pH}$ & $\begin{array}{c}\text { Alcalinidade } \\
\text { Total }(\mathrm{mg} / \mathrm{L} \\
\left.\mathrm{CaCO}_{3}\right)\end{array}$ & $\begin{array}{c}\text { SSV } \\
(\mathrm{mg} / \mathrm{L})\end{array}$ & $\begin{array}{c}\mathrm{DBO} \\
(\mathrm{mg} / \mathrm{L})\end{array}$ & $\begin{array}{c}\text { Taxa de } \\
\text { Desnitrificação } \\
\text { (Kg NO3-, } \\
\text { NO2-/ Kg } \\
\text { SSV.dia) }\end{array}$ & $\begin{array}{l}\text { Nitrito } \\
\text { (mg/L) }\end{array}$ & $\begin{array}{l}\text { Nitrato } \\
(\mathrm{mg} / \mathrm{L})\end{array}$ & $\begin{array}{l}\mathrm{N}-\mathrm{NH}_{3} \\
(\mathrm{mg} / \mathrm{L})\end{array}$ & $\begin{array}{l}\text { Tempo da } \\
\text { etapa (h) }\end{array}$ & $\begin{array}{c}\text { Eficiência na } \\
\text { remoção de } \\
\mathrm{N}-\mathrm{NO}_{2}^{-} / \mathrm{N}- \\
\mathrm{NO}_{3}^{-}(\%)\end{array}$ \\
\hline 2 & 8,6 & 3760 & 4120 & 70 & 0,0124 & 0 & 3 & 210 & 90 & 98,5 \\
\hline \multicolumn{11}{|c|}{ Fase Aerada } \\
\hline \multicolumn{11}{|c|}{ Final da etapa aerada } \\
\hline Ciclo & $\mathrm{pH}$ & $\begin{array}{c}\text { Alcalinidade } \\
\text { Total }(\mathrm{mg} / \mathrm{L} \\
\left.\mathrm{CaCO}_{3}\right)\end{array}$ & $\begin{array}{c}\text { SSV } \\
(\mathrm{mg} / \mathrm{L})\end{array}$ & $\begin{array}{c}\mathrm{DBO} \\
(\mathrm{mg} / \mathrm{L})\end{array}$ & $\begin{array}{l}\text { Tempo da } \\
\text { etapa (h) }\end{array}$ & $\begin{array}{l}\text { Nitrito } \\
\text { (mg/L) }\end{array}$ & $\begin{array}{l}\text { Nitrato } \\
(\mathrm{mg} / \mathrm{L})\end{array}$ & $\begin{array}{l}\mathrm{N}-\mathrm{NH}_{3} \\
(\mathrm{mg} / \mathrm{L})\end{array}$ & $\begin{array}{c}\text { Taxa de } \\
\text { Nitrificação } \\
(\mathrm{Kg} \mathrm{N}- \\
\mathrm{NH}_{3} / \mathrm{Kg} \\
\text { SSV.dia) }\end{array}$ & $\begin{array}{c}\text { Eficiência na } \\
\text { remoção de } \\
\mathrm{N}-\mathrm{NH}_{3}(\%)\end{array}$ \\
\hline 2 & 8,1 & 3530 & 3690 & 20 & 28 & 52,0 & 144 & 3 & 0,048 & 98,6 \\
\hline
\end{tabular}


Comparando-se o primeiro com o segundo ciclo de tratamento nota-se que a formação de nitrito no segundo ciclo foi maior, o que evidencia que o acúmulo de nitrito pode também estar relacionado à adaptação dos microrganismos as condições operacionais que propiciem este acúmulo.

Não houve controle de temperatura em nenhum dos ciclos de tratamento do sistema R-1. Para a temperatura média no ciclo 2 igual a $23{ }^{\circ} \mathrm{C}$, a concentração de amônia livre no reator variou de $20,2 \mathrm{mg} / \mathrm{L}$ (inicio etapa aerada) a $0,21 \mathrm{mg} / \mathrm{L}$ (final da etapa aerada).

A taxa de desnitrificação (tabela 15) foi menor no ciclo 2 do que no ciclo 1; A maior concentração de compostos recalcitrantes do aterro bandeirantes em comparação ao aterro São João pode ter ocasionado esse maior tempo da etapa anóxica.

$\mathrm{Na}$ seqüência do tratamento, a figura 49 e a tabela 16 trazem as características físico-químicas e taxas do ultimo ciclo da primeira fase da pesquisa.

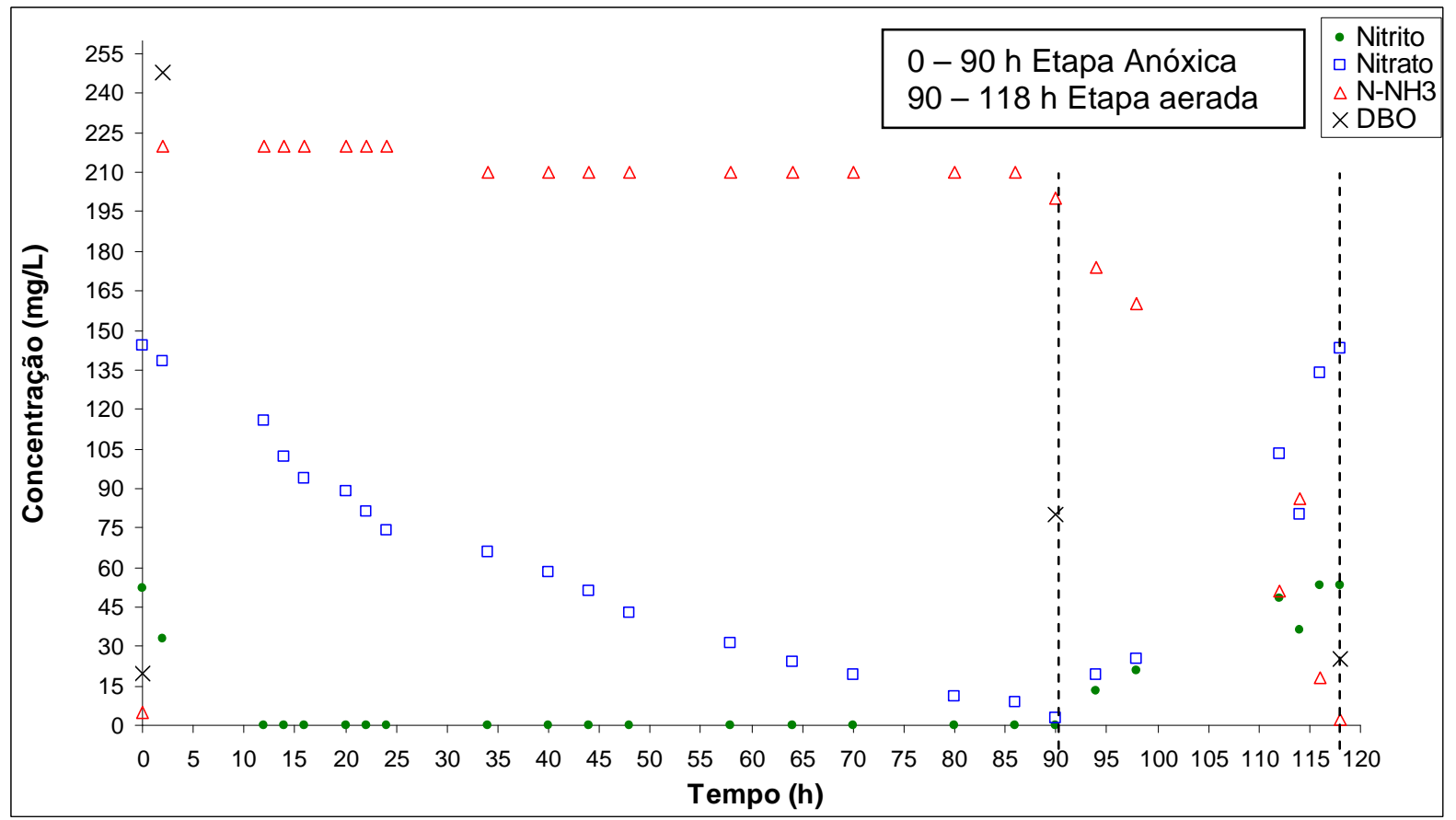

Figura 48 - Perfis temporais das concentrações de DBO, N-NO ${ }_{2}^{-}, \mathrm{N}-\mathrm{NO}_{3}{ }^{-}$e N-NH${ }_{3}+$ durante o ultimo ciclo de tratamento do reator R-1/Fase1 - Aterro Bandeirantes. 
Tabela 16 - Características físico-químicas e taxas do ultimo ciclo de tratamento utilizando o sistema R-1 (primeira fase - aterro Bandeirantes)

Fase Anóxica

Inicio da etapa anóxica (após alimentação)

\begin{tabular}{|c|c|c|c|c|c|c|c|c|c|c|}
\hline Ciclo & $\mathrm{pH}$ & $\begin{array}{c}\text { Alcalinidade } \\
\text { Total }(\mathrm{mg} / \mathrm{L} \\
\left.\mathrm{CaCO}_{3}\right)\end{array}$ & $\begin{array}{l}\text { SSV } \\
(\mathrm{mg} / \mathrm{L})\end{array}$ & $\begin{array}{c}\text { DBO } \\
\text { (mg/L) }\end{array}$ & $\begin{array}{c}\text { Relação } \\
\mathrm{DBO}_{\text {removidal }} \\
\text { Nitrito- } \\
\text { Nitrato } \\
\left(\mathrm{Kg} \mathrm{DBOmovido}^{-} \mathrm{Kg}\right. \\
\left.\mathrm{NO}_{3}^{-}, \mathrm{NO}_{2}^{-}\right)\end{array}$ & $\begin{array}{l}\text { Nitrito } \\
(\mathrm{mg} / \mathrm{L})\end{array}$ & $\begin{array}{l}\text { Nitrato } \\
\text { (mg/L) }\end{array}$ & $\begin{array}{l}\mathrm{N}-\mathrm{NH}_{3} \\
(\mathrm{mg} / \mathrm{L})\end{array}$ & $\begin{array}{c}\text { Eficiência } \\
\text { na } \\
\text { remoção } \\
\text { de DBO do } \\
\text { ciclo }(\%)\end{array}$ & $\begin{array}{l}\text { Temperatura } \\
\text { média do } \\
\text { ciclo }\left({ }^{0} \mathrm{C}\right)\end{array}$ \\
\hline 3 & 8,2 & 3340 & 3900 & 248 & 0,87 & 52 & 144 & 220 & 89,9 & 24 \\
\hline \multicolumn{11}{|c|}{ Final da etapa anóxica = Início da etapa aerada } \\
\hline Ciclo & $\mathrm{pH}$ & $\begin{array}{c}\text { Alcalinidade } \\
\text { Total }(\mathrm{mg} / \mathrm{L} \\
\left.\mathrm{CaCO}_{3}\right)\end{array}$ & $\begin{array}{c}\text { SSV } \\
(\mathrm{mg} / \mathrm{L})\end{array}$ & $\begin{array}{c}\text { DBO } \\
\text { (mg/L) }\end{array}$ & $\begin{array}{c}\text { Taxa de } \\
\text { Desnitrificação } \\
\text { (Kg NO3-, } \\
\text { NO2-/ Kg } \\
\text { SSV.dia) }\end{array}$ & $\begin{array}{l}\text { Nitrito } \\
(\mathrm{mg} / \mathrm{L})\end{array}$ & $\begin{array}{l}\text { Nitrato } \\
(\mathrm{mg} / \mathrm{L})\end{array}$ & $\begin{array}{l}\mathrm{N}-\mathrm{NH}_{3} \\
(\mathrm{mg} / \mathrm{L})\end{array}$ & $\begin{array}{l}\text { Tempo da } \\
\text { etapa (h) }\end{array}$ & $\begin{array}{c}\text { Eficiência na } \\
\text { remoção de } \\
\mathrm{N}-\mathrm{NO}_{2}^{-} / \mathrm{N}- \\
\mathrm{NO}_{3}^{-}(\%)\end{array}$ \\
\hline 3 & 8,5 & 3710 & 4170 & 80 & 0,0123 & 0 & 3 & 210 & 90 & 98,5 \\
\hline \multicolumn{11}{|c|}{ Fase Aerada } \\
\hline \multicolumn{11}{|c|}{ Final da etapa aerada } \\
\hline Ciclo & $\mathrm{pH}$ & $\begin{array}{c}\text { Alcalinidade } \\
\text { Total }(\mathrm{mg} / \mathrm{L} \\
\left.\mathrm{CaCO}_{3}\right)\end{array}$ & $\begin{array}{c}\text { SSV } \\
(\mathrm{mg} / \mathrm{L})\end{array}$ & $\begin{array}{c}\text { DBO } \\
(\mathrm{mg} / \mathrm{L})\end{array}$ & $\begin{array}{l}\text { Tempo da } \\
\text { etapa }(\mathrm{h})\end{array}$ & $\begin{array}{l}\text { Nitrito } \\
\text { (mg/L) }\end{array}$ & $\begin{array}{l}\text { Nitrato } \\
(\mathrm{mg} / \mathrm{L})\end{array}$ & $\begin{array}{l}\mathrm{N}-\mathrm{NH}_{3} \\
(\mathrm{mg} / \mathrm{L})\end{array}$ & $\begin{array}{c}\text { Taxa de } \\
\text { Nitrificação } \\
\text { (Kg N-NH} / \\
\text { Kg } \\
\text { SSV.dia) }\end{array}$ & $\begin{array}{c}\text { Eficiência na } \\
\text { remoção de } \\
\mathrm{N}-\mathrm{NH}_{3}(\%)\end{array}$ \\
\hline 3 & 8,2 & 3450 & 4250 & 25 & 28 & 53 & 143 & 2 & 0,042 & 99,0 \\
\hline
\end{tabular}

Analisando-se a figura 49 e a tabela 16 nota-se que mesmo com uma maior formação de nitrito em comparação com o ciclo anterior, neste ciclo houve ainda uma predominância na formação de nitrato ocasionado possivelmente pela não adaptação do sistema ás condições operacionais adotadas para o sistema R-1. Devido a alta concentração de nitrogênio amoniacal do lixiviado bruto, o período aerado do ciclo foi relativamente extenso provocando assim uma queda acentuada no $\mathrm{pH}$ (grande consumo de alcalinidade) durante esta etapa sendo que, este foi mais um dos possíveis motivos que dificultaram o acúmulo de nitrito. Mesmo com longos tempos de cada etapa do ciclo a remoção de nitrogênio global durante o ciclo foi satisfatória, ficando acima de 98\%. Já a eficiência na remoção de DBO ficou acima de $89 \%$. Outro fator que, teoricamente, deveria favorecer o acúmulo de nitrito foi a concentração de amônia livre que variou entre $20,67 \mathrm{mg} / \mathrm{L}$ (início etapa aerada) e $0,19 \mathrm{mg} / \mathrm{L}$ (final etapa aerada) contudo, esta teoria não foi confirmada na prática. 


\subsubsection{FASE 02 - ALIMENTAÇÃO DO SISTEMA COM LIXIVIADO PRÉ-TRATADO ("STRIPPING" DE AMÔNIA ATÉ A CONCENTRAÇÃO DE APROXIMADAMENTE $1200 \mathrm{MG} / \mathrm{L})$}

Como um dos principais objetivos da pesquisa era avaliar a remoção de nitrogênio pela via curta (acúmulo de nitrito) e este objetivo não foi alcançado na primeira fase, optou-se por alterar as condições operacionais do sistema R-2. Para isso, foi efetuado um pré-tratamento do lixiviado bruto que consistia em um "stripping" de amônia até que a concentração do lixiviado bruto atingisse aproximadamente 1200 $\mathrm{mg} / \mathrm{L}$. O objetivo de se reduzir a concentração de nitrogênio amoniacal do lixiviado bruto era justamente reduzir o tempo da etapa aerada e conseqüentemente a perda excessiva de alcalinidade durante esta fase que, tinha como conseqüência a redução acentuada do $\mathrm{pH}$ da massa líquida. A mudança da concentração de nitrogênio amoniacal objetivou facilitar a operacionalidade do sistema como, por exemplo, eliminar a necessidade de adição de alcalinizante durante a etapa aeróbia. A figura 50 e a tabela 17 demonstram as características físico-químicas e as taxas relativas ao primeiro ciclo de tratamento da fase 2. Neste ciclo em específico o sistema foi alimentado com lixiviado pré-tratado do aterro São João.

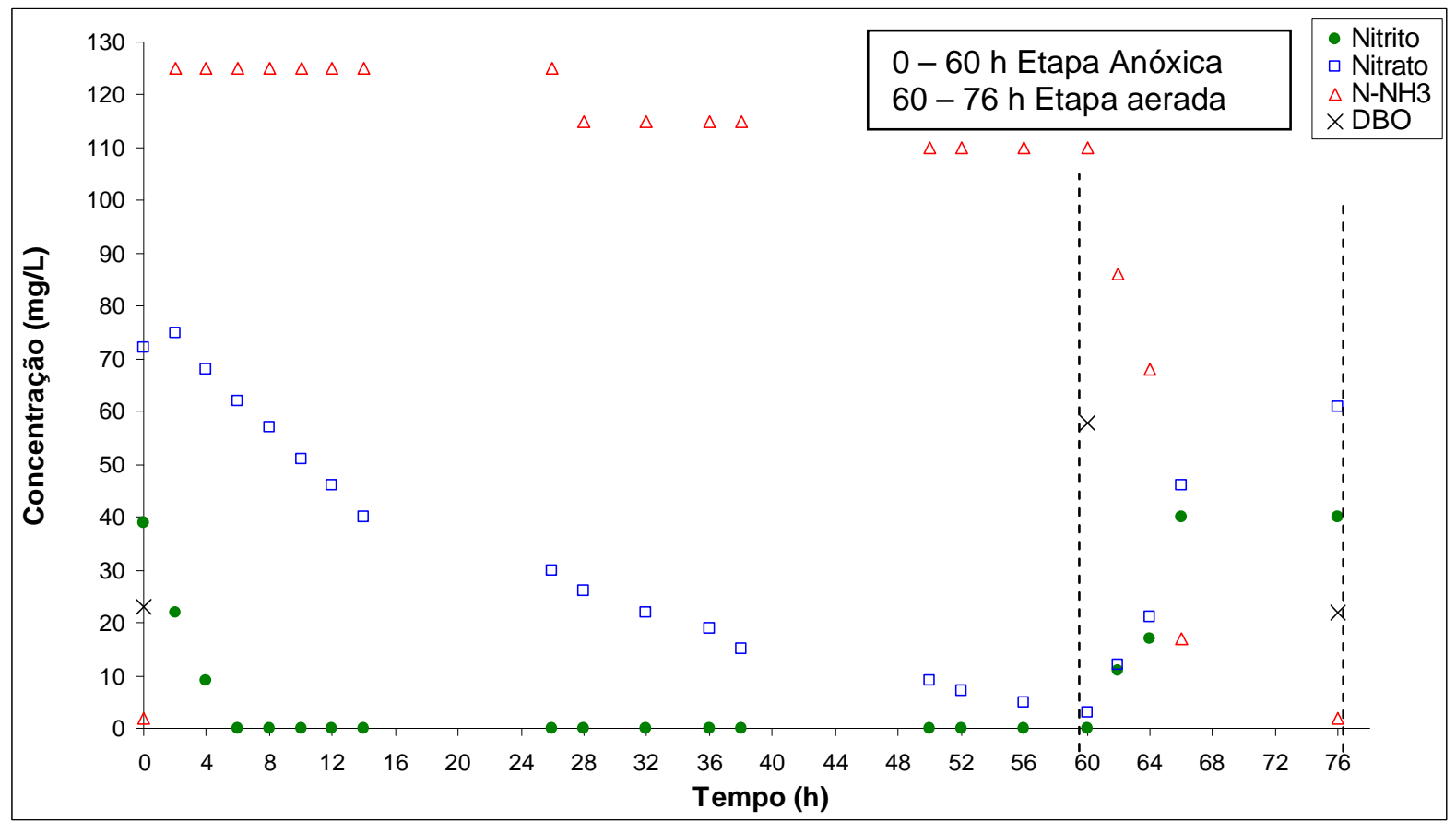

Figura 49- Perfis temporais das concentrações de $\mathrm{DBO}, \mathrm{N}-\mathrm{NO}_{2}^{-}, \mathrm{N}-\mathrm{NO}_{3}^{-}$e N-NH${ }_{3}+$ durante o primeiro ciclo de tratamento do reator R-1/Fase 2 - Aterro São João. 
Tabela 17 - Características físico-químicas e taxas do primeiro ciclo de tratamento utilizando o sistema R-1 (segunda fase - Aterro São João).

\begin{tabular}{|c|c|c|c|c|c|c|c|c|c|c|}
\hline \multicolumn{11}{|c|}{ Fase Anóxica } \\
\hline \multicolumn{11}{|c|}{ Inicio da etapa anóxica (após alimentação) } \\
\hline Ciclo & $\mathrm{pH}$ & $\begin{array}{c}\text { Alcalinidade } \\
\text { Total }(\mathrm{mg} / \mathrm{L} \\
\left.\mathrm{CaCO}_{3}\right)\end{array}$ & $\begin{array}{c}\text { SSV } \\
(\mathrm{mg} / \mathrm{L})\end{array}$ & $\begin{array}{l}\mathrm{DBO} \\
(\mathrm{mg} / \mathrm{L})\end{array}$ & $\begin{array}{c}\text { Relação } \\
\mathrm{DBO}_{\text {removidal }} \\
\text { Nitrito- } \\
\text { Nitratoremovido } \\
(\mathrm{Kg} \mathrm{DBO} / \mathrm{Kg} \\
\left.\mathrm{NO}_{3}^{-}, \mathrm{NO}_{2}^{-}\right)^{-}\end{array}$ & $\begin{array}{l}\text { Nitrito } \\
\text { (mg/L) }\end{array}$ & $\begin{array}{l}\text { Nitrato } \\
(\mathrm{mg} / \mathrm{L})\end{array}$ & $\begin{array}{l}\mathrm{N}-\mathrm{NH}_{3} \\
(\mathrm{mg} / \mathrm{L})\end{array}$ & $\begin{array}{l}\text { Eficiência } \\
\text { na } \\
\text { remoção } \\
\text { de DBO do } \\
\text { ciclo (\%) }\end{array}$ & $\begin{array}{c}\text { Temperatura } \\
\text { média do } \\
\text { ciclo }\left({ }^{0} \mathrm{C}\right)\end{array}$ \\
\hline 1 & 8,1 & 3560 & 3580 & 146 & 0,81 & 39 & 72 & 125 & 84,9 & 25 \\
\hline \multicolumn{11}{|c|}{ Final da etapa anóxica = Início da etapa aerada } \\
\hline Ciclo & $\mathrm{pH}$ & $\begin{array}{c}\text { Alcalinidade } \\
\text { Total }(\mathrm{mg} / \mathrm{L} \\
\left.\mathrm{CaCO}_{3}\right)\end{array}$ & $\begin{array}{c}\text { SSV } \\
(\mathrm{mg} / \mathrm{L})\end{array}$ & $\begin{array}{l}\mathrm{DBO} \\
(\mathrm{mg} / \mathrm{L})\end{array}$ & $\begin{array}{c}\text { Taxa de } \\
\text { Desnitrificação } \\
\text { (Kg NO3-, } \\
\text { NO2-/ Kg } \\
\text { SSV.dia) }\end{array}$ & $\begin{array}{l}\text { Nitrito } \\
\text { (mg/L) }\end{array}$ & $\begin{array}{l}\text { Nitrato } \\
(\mathrm{mg} / \mathrm{L})\end{array}$ & $\begin{array}{l}\mathrm{N}-\mathrm{NH}_{3} \\
(\mathrm{mg} / \mathrm{L})\end{array}$ & $\begin{array}{l}\text { Tempo da } \\
\text { etapa (h) }\end{array}$ & 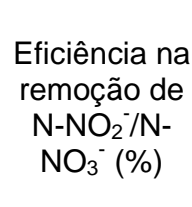 \\
\hline 1 & 8,6 & 3830 & 3790 & 58 & 0,0114 & 0 & 3 & 110 & 60 & 97,3 \\
\hline \multicolumn{11}{|c|}{ Fase Aerada } \\
\hline \multicolumn{11}{|c|}{ Final da etapa aerada } \\
\hline Ciclo & $\mathrm{pH}$ & $\begin{array}{c}\text { Alcalinidade } \\
\text { Total }(\mathrm{mg} / \mathrm{L} \\
\left.\mathrm{CaCO}_{3}\right)\end{array}$ & $\begin{array}{c}\text { SSV } \\
(\mathrm{mg} / \mathrm{L})\end{array}$ & $\begin{array}{l}\mathrm{DBO} \\
(\mathrm{mg} / \mathrm{L})\end{array}$ & $\begin{array}{l}\text { Tempo da } \\
\text { etapa (h) }\end{array}$ & $\begin{array}{l}\text { Nitrito } \\
\text { (mg/L) }\end{array}$ & $\begin{array}{l}\text { Nitrato } \\
\text { (mg/L) }\end{array}$ & $\begin{array}{l}\mathrm{N}-\mathrm{NH}_{3} \\
(\mathrm{mg} / \mathrm{L})\end{array}$ & $\begin{array}{c}\text { Taxa de } \\
\text { Nitrificação } \\
\text { (Kg N-NH }{ }_{3} / \\
\mathrm{Kg} \\
\text { SSV.dia) }\end{array}$ & $\begin{array}{c}\text { Eficiência na } \\
\text { remoção de } \\
\mathrm{N}-\mathrm{NH}_{3}(\%)\end{array}$ \\
\hline 1 & 8,2 & 3490 & 3810 & 22 & 16 & 40 & 61 & 2 & 0,043 & 98,2 \\
\hline
\end{tabular}

Nota-se através da figura 50 que mesmo alterando-se a concentração de nitrogênio amoniacal do lixiviado bruto, houve uma predominância na formação de nitrato durante a etapa aeróbia. Outro fato que se repetiu durante este primeiro ciclo de tratamento foi a queda acentuada do $\mathrm{pH}$ durante a etapa aeróbia obrigando assim, a adição de alcalinizante durante a etapa.

O tempo da etapa aeróbia foi reduzido de uma média de 28 horas da fase 1 para 16 horas no primeiro ciclo de tratamento da fase 2 confirmando assim, que o tempo da etapa aerada é proporcional a concentração inicial de nitrogênio da massa líquida.

Tanto nesta etapa quanto na etapa 1 não houve o controle sistemático da quantidade de oxigênio introduzida na massa líquida durante a etapa aeróbia porém, procurou-se manter a concentração de oxigênio no reator próximo a $1 \mathrm{mg} / \mathrm{L}$.

Houve também uma diminuição da etapa anóxica do ciclo mostrando assim que a concentração de nitrito/nitrato é diretamente proporcional ao tempo da etapa 
anóxica. O grande limitante da etapa anóxica do sistema foi a concentração de matéria orgânica disponível para a redução do nitrito/nitrato formado durante a etapa aeróbia, ou seja, a dificuldade dos microrganismos em utilizar a matéria orgânica recalcitrante presente no lixiviado provocou um aumento no tempo da etapa anóxica.

Apesar de a temperatura influenciar diretamente a velocidade específica de crescimento dos microrganismos, não foi feito nenhuma manipulação na temperatura do sistema durante esta fase.

Nesta fase a concentração de amônia livre no reator variou entre $9,47 \mathrm{mg} / \mathrm{L}$ (inicio etapa aerada) e 0,18 mg/L (final etapa aerada) valores estes que segundo Anthonisen et al. (1976) podem ser tóxicos as bactérias oxidantes de nitrito, ou seja, esta condição da massa líquida era favorável ao acúmulo de nitrito.

Nota-se através das figuras 51, 52, 53 e 54 bem como das tabelas 17, 18, 19 e 20 a seguir, que o comportamento do sistema foi praticamente o mesmo observado durante o primeiro ciclo desta etapa, ou seja, mesmo com as concentrações de amônia livre no reator favoráveis a inibição da nitratação, houve uma maior formação de nitrato do que nitrito.

É importante ressaltar que durante todos os ciclos desta etapa foi necessário a adição de alcalinizante para evitar a queda acentuada do $\mathrm{pH}$ durante a etapa aeróbia do ciclo. 


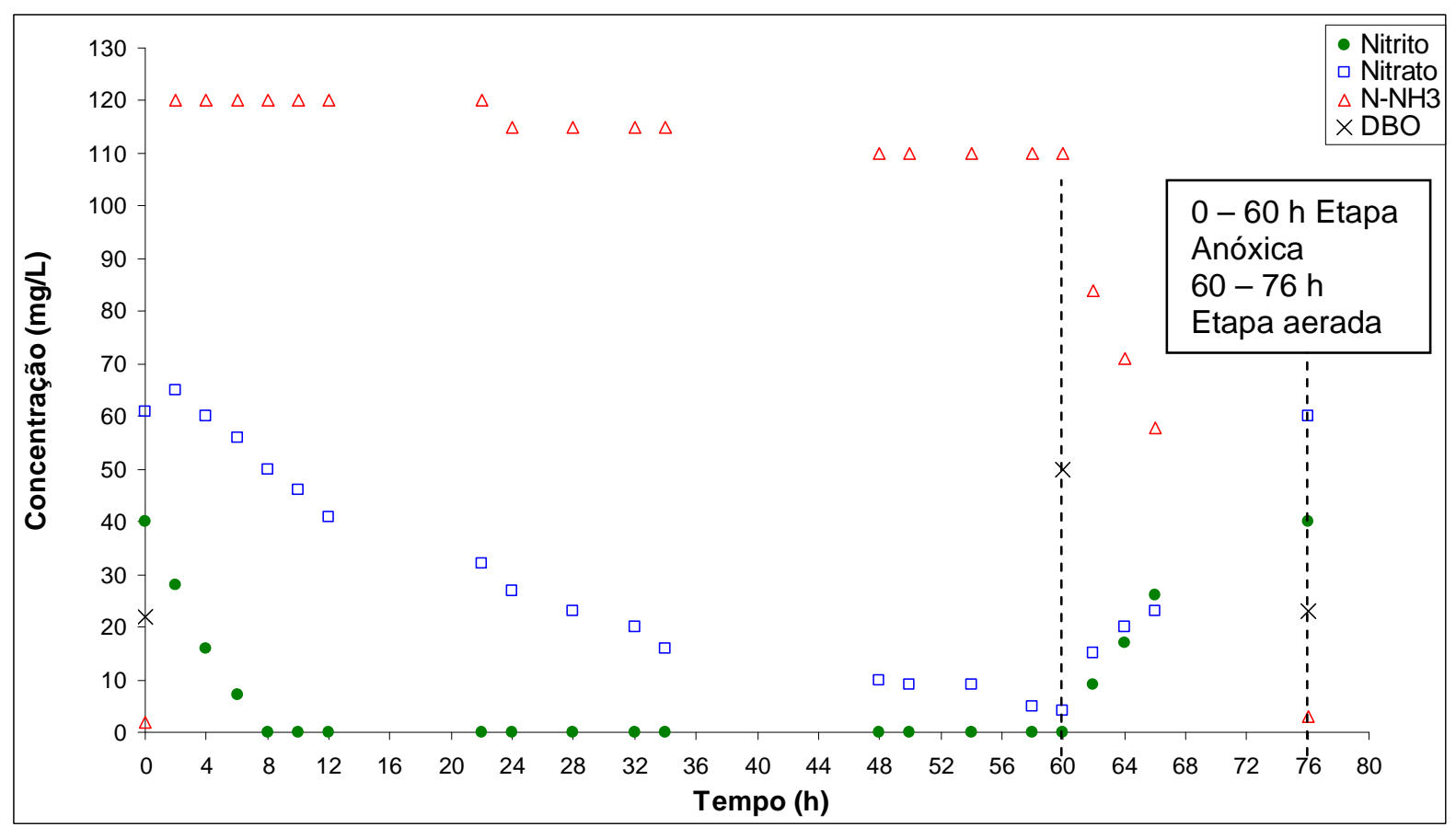

Figura 50 - Perfis temporais das concentrações de $\mathrm{DBO}, \mathrm{N}-\mathrm{NO}_{2}^{-}, \mathrm{N}-\mathrm{NO}_{3}{ }^{-}$e N- $\mathrm{NH}_{3}+$ durante o segundo ciclo de tratamento do reator R-1/Fase 2 - Aterro Bandeirantes.

Tabela 18 - Características físico-químicas e taxas do segundo ciclo de tratamento utilizando o sistema R-1 (segunda fase - Aterro Bandeirantes).

Inicio da etapa anóxica (após alimentação)

\begin{tabular}{|c|c|c|c|c|c|c|c|c|c|c|}
\hline Ciclo & $\mathrm{pH}$ & $\begin{array}{l}\text { Alcalinidade } \\
\text { Total }\left(\mathrm{mg}^{\prime} / \mathrm{L}\right. \\
\left.\mathrm{CaCO}_{3}\right)\end{array}$ & $\begin{array}{c}\text { SSV } \\
\text { (mg/L) }\end{array}$ & $\begin{array}{c}\mathrm{DBO} \\
(\mathrm{mg} / \mathrm{L})\end{array}$ & $\begin{array}{c}\text { Relação } \\
\text { DBOremovidal } \\
\text { Nitrito- } \\
\text { Nitratoremovido } \\
\text { (Kg DBO/Kg }\end{array}$ & $\begin{array}{l}\text { Nitrito } \\
\text { (mg/L) }\end{array}$ & $\begin{array}{l}\text { Nitrato } \\
\text { (mg/L) }\end{array}$ & $\begin{array}{l}\mathrm{N}-\mathrm{NH}_{3} \\
(\mathrm{mg} / \mathrm{L})\end{array}$ & $\begin{array}{c}\text { Eficiência } \\
\text { na } \\
\text { remoção } \\
\text { de DBO do } \\
\text { ciclo (\%) }\end{array}$ & $\begin{array}{l}\text { Temperatura } \\
\text { média do } \\
\text { ciclo }\left({ }^{0} \mathrm{C}\right)\end{array}$ \\
\hline
\end{tabular}

\begin{tabular}{|c|c|c|c|c|c|c|c|c|c|c|}
\hline 2 & 8,2 & 3160 & 3720 & 145 & 0,97 & 40 & 61 & 120 & 84,1 & 25 \\
\hline \multicolumn{11}{|c|}{ Final da etapa anóxica = Início da etapa aerada } \\
\hline Ciclo & $\mathrm{pH}$ & $\begin{array}{c}\text { Alcalinidade } \\
\text { Total }(\mathrm{mg} / \mathrm{L} \\
\left.\mathrm{CaCO}_{3}\right)\end{array}$ & $\begin{array}{c}\text { SSV } \\
(\mathrm{mg} / \mathrm{L})\end{array}$ & $\begin{array}{c}\mathrm{DBO} \\
(\mathrm{mg} / \mathrm{L})\end{array}$ & $\begin{array}{c}\text { Taxa de } \\
\text { Desnitrificação } \\
\text { (Kg NO3-, } \\
\text { NO2-/ Kg } \\
\text { SSV.dia) }\end{array}$ & $\begin{array}{l}\text { Nitrito } \\
(\mathrm{mg} / \mathrm{L})\end{array}$ & $\begin{array}{l}\text { Nitrato } \\
\text { (mg/L) }\end{array}$ & $\begin{array}{l}\mathrm{N}-\mathrm{NH}_{3} \\
(\mathrm{mg} / \mathrm{L})\end{array}$ & $\begin{array}{l}\text { Tempo da } \\
\text { etapa }(\mathrm{h})\end{array}$ & 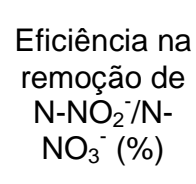 \\
\hline
\end{tabular}

\begin{tabular}{|c|c|c|c|c|c|c|c|c|c|c|}
\hline 2 & 8,5 & 3530 & 3810 & 50 & 0,0103 & 0 & 3 & 110 & 60 & 97,0 \\
\hline \multicolumn{11}{|c|}{ Fase Aerada } \\
\hline \multicolumn{11}{|c|}{ Final da etapa aerada } \\
\hline Ciclo & $\mathrm{pH}$ & $\begin{array}{c}\text { Alcalinidade } \\
\text { Total }(\mathrm{mg} / \mathrm{L} \\
\left.\mathrm{CaCO}_{3}\right)\end{array}$ & $\begin{array}{l}\text { SSV } \\
(\mathrm{mg} / \mathrm{L})\end{array}$ & $\begin{array}{l}\text { DBO } \\
\text { (mg/L) }\end{array}$ & $\begin{array}{l}\text { Tempo da } \\
\text { etapa (h) }\end{array}$ & $\begin{array}{l}\text { Nitrito } \\
(\mathrm{mg} / \mathrm{L})\end{array}$ & $\begin{array}{l}\text { Nitrato } \\
(\mathrm{mg} / \mathrm{L})\end{array}$ & $\begin{array}{l}\mathrm{N}-\mathrm{NH}_{3} \\
(\mathrm{mg} / \mathrm{L})\end{array}$ & $\begin{array}{c}\text { Taxa de } \\
\text { Nitrificação } \\
(\mathrm{Kg} \mathrm{N}- \\
\mathrm{NH}_{3} / \mathrm{Kg} \\
\mathrm{SSV} . \text { dia) }\end{array}$ & $\begin{array}{c}\text { Eficiência na } \\
\text { remoção de } \\
\mathrm{N}-\mathrm{NH}_{3}(\%)\end{array}$ \\
\hline 2 & 8,1 & 3290 & 3940 & 23 & 16 & 40 & 60 & 3 & 0,041 & 97,3 \\
\hline
\end{tabular}




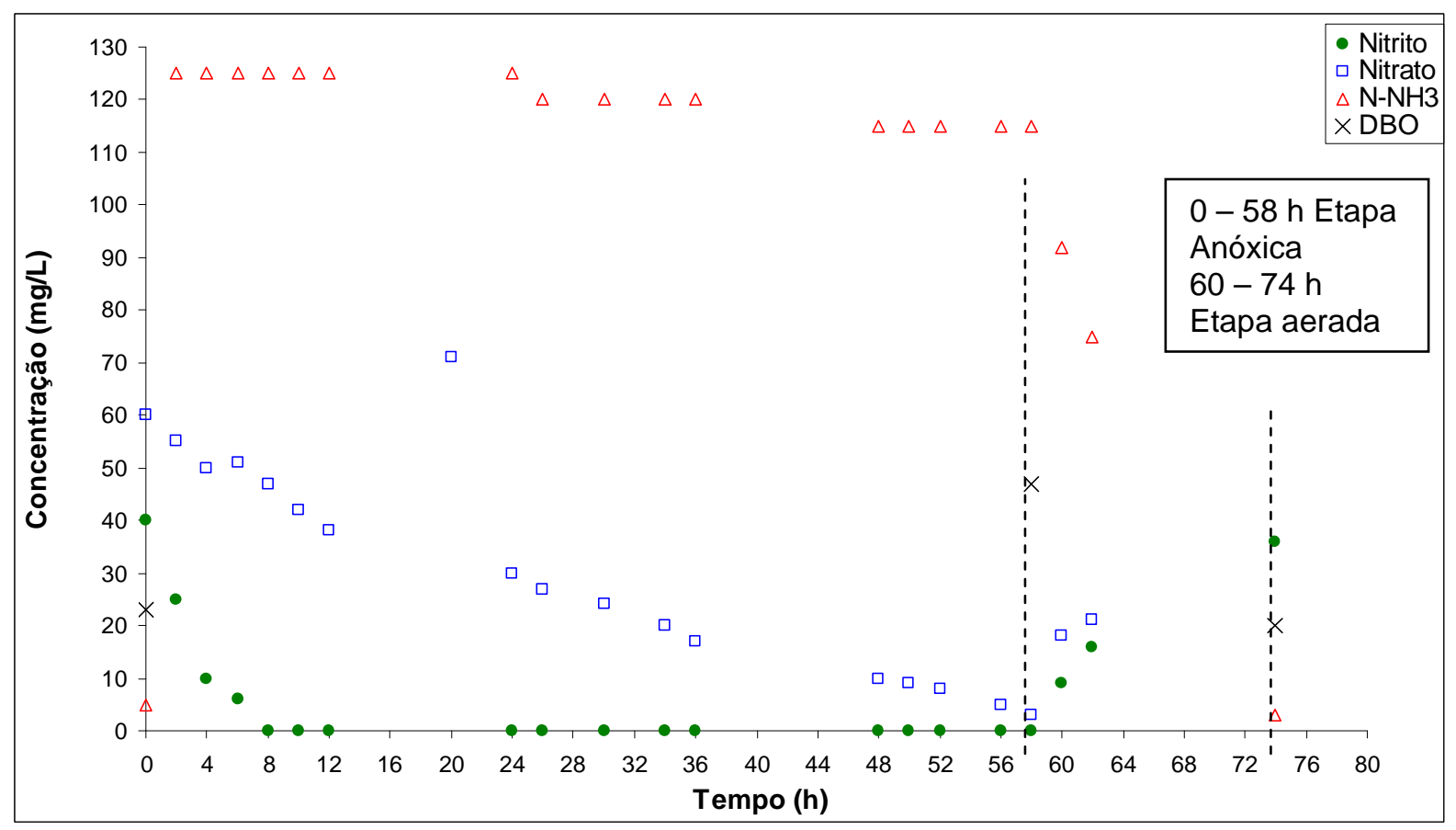

Figura 51 - Perfis temporais das concentrações de $\mathrm{DBO}, \mathrm{N}-\mathrm{NO}_{2}^{-}, \mathrm{N}-\mathrm{NO}_{3}^{-}$e $\mathrm{N}-\mathrm{NH}_{3}+$ durante o terceiro ciclo de tratamento do reator R-1/Fase 2 - Aterro Bandeirantes.

Tabela 19 - Características físico-químicas e taxas do terceiro ciclo de tratamento utilizando o sistema R-1 (segunda fase - Aterro Bandeirantes). Fase Anóxica

Inicio da etapa anóxica (após alimentação)

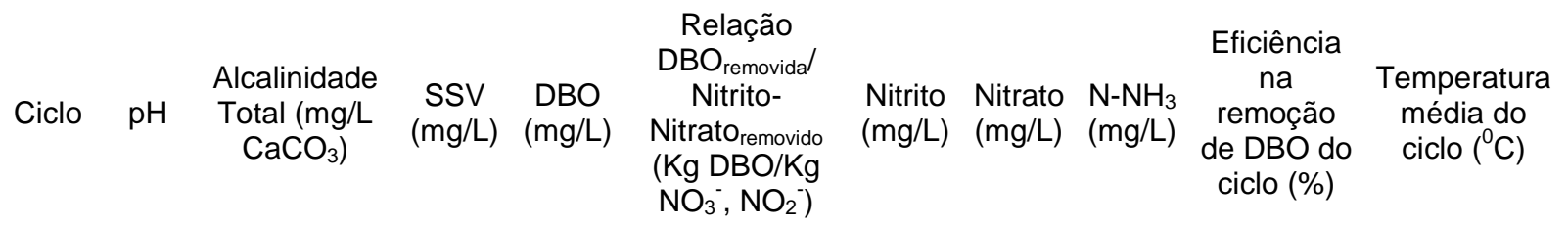

\begin{tabular}{ccccccccccc}
\hline 3 & 8,1 & 3710 & 3880 & 140 & 0,96 & 40 & 60 & 125 & 85,7 & 24 \\
\hline
\end{tabular}

\begin{tabular}{|c|c|c|c|c|c|c|c|c|c|c|}
\hline Ciclo & $\mathrm{pH}$ & $\begin{array}{c}\text { Alcalinidade } \\
\text { Total }\left(\mathrm{mg}^{\prime} / \mathrm{L}\right. \\
\left.\mathrm{CaCO}_{3}\right)\end{array}$ & $\begin{array}{l}\text { SSV } \\
\text { (mg/L) }\end{array}$ & $\begin{array}{c}\text { DBO } \\
\text { (mg/L) }\end{array}$ & $\begin{array}{c}\text { Taxa de } \\
\text { Desnitrificação } \\
\text { (Kg NO3-, } \\
\text { NO2-/ Kg } \\
\text { SSV dia) }\end{array}$ & $\begin{array}{l}\text { Nitrito } \\
\text { (mg/L) }\end{array}$ & $\begin{array}{l}\text { Nitrato } \\
(\mathrm{mg} / \mathrm{L})\end{array}$ & $\begin{array}{l}\mathrm{N}-\mathrm{NH}_{3} \\
(\mathrm{mg} / \mathrm{L})\end{array}$ & $\begin{array}{l}\text { Tempo da } \\
\text { etapa }(h)\end{array}$ & 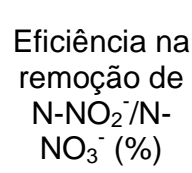 \\
\hline
\end{tabular}

\begin{tabular}{lllllllllll}
\hline 3 & 8,5 & 3900 & 4030 & 47 & 0,0100 & 0 & 3 & 115 & 58 & 97,0 \\
\hline \multicolumn{10}{c}{ Fase Aerada } \\
\hline \multicolumn{10}{c}{ Final da etapa aerada } \\
\hline
\end{tabular}

\begin{tabular}{|c|c|c|c|c|c|c|c|c|c|c|}
\hline Ciclo & $\mathrm{pH}$ & $\begin{array}{c}\text { Alcalinidade } \\
\text { Total }(\mathrm{mg} / \mathrm{L} \\
\left.\mathrm{CaCO}_{3}\right)\end{array}$ & $\begin{array}{c}\text { SSV } \\
(\mathrm{mg} / \mathrm{L})\end{array}$ & $\begin{array}{l}\text { DBO } \\
\text { (mg/L) }\end{array}$ & $\begin{array}{l}\text { Tempo da } \\
\text { etapa }(\mathrm{h})\end{array}$ & $\begin{array}{l}\text { Nitrito } \\
\text { (mg/L) }\end{array}$ & $\begin{array}{l}\text { Nitrato } \\
(\mathrm{mg} / \mathrm{L})\end{array}$ & $\begin{array}{l}\mathrm{N}-\mathrm{NH}_{3} \\
\text { (mg/L) }\end{array}$ & $\begin{array}{c}\text { Taxa de } \\
\text { Nitrificação } \\
(\mathrm{Kg} \mathrm{N}- \\
\mathrm{NH}_{3} / \mathrm{Kg} \\
\mathrm{SSV} \text { dia) }\end{array}$ & $\begin{array}{c}\text { Eficiência na } \\
\text { remoção de } \\
\mathrm{N}-\mathrm{NH}_{3}(\%)\end{array}$ \\
\hline
\end{tabular}

\begin{tabular}{lllllllllll}
3 & 8 & 3650 & 3950 & 20 & 16 & 36 & 71 & 3 & 0,043 & 97,4 \\
\hline
\end{tabular}




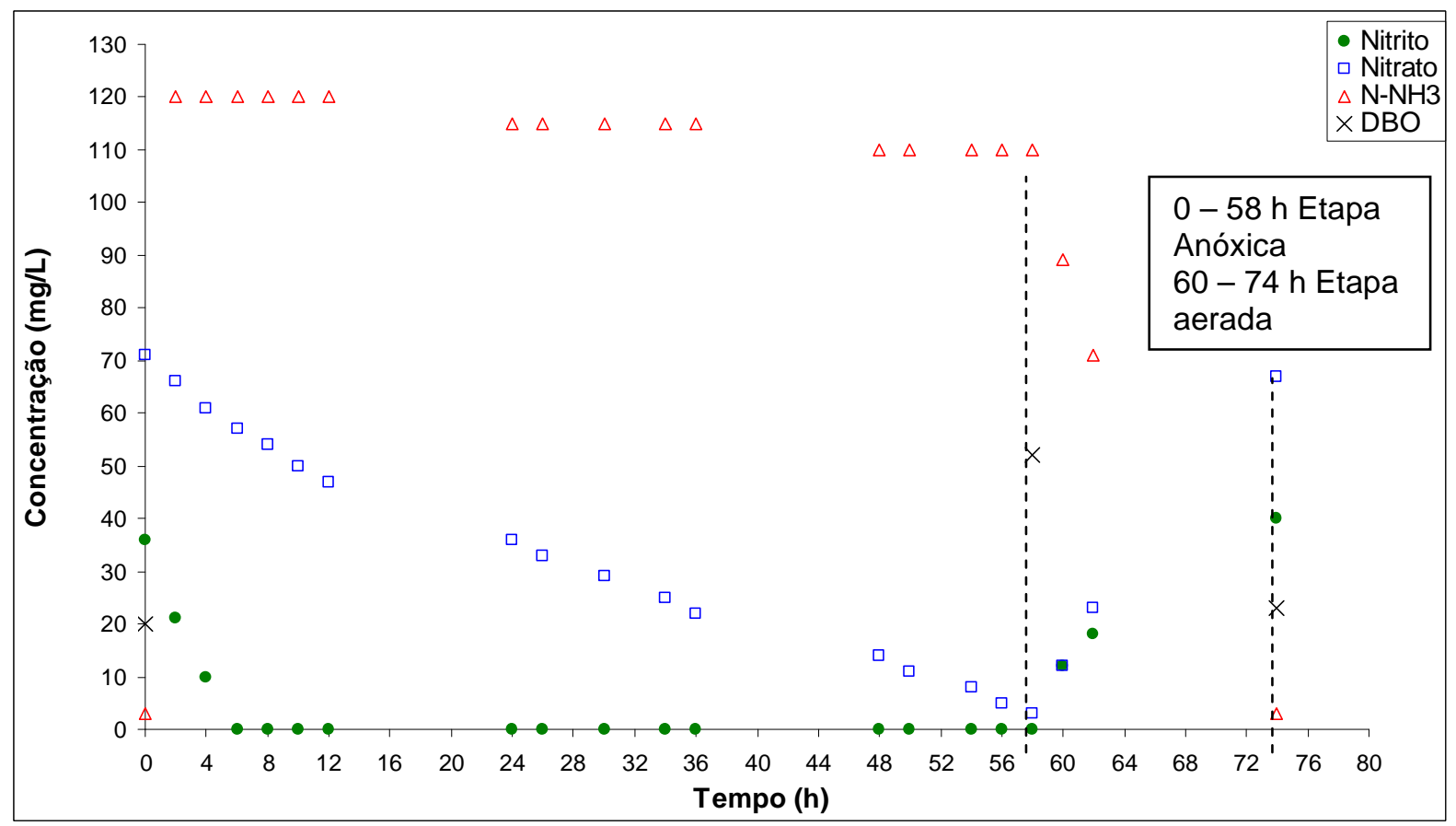

Figura 52 - Perfis temporais das concentrações de DBO, N-NO ${ }_{2}^{-}, \mathrm{N}-\mathrm{NO}_{3}{ }^{-}$e N- $\mathrm{NH}_{3}+$ durante o quarto ciclo de tratamento do reator R-1/Fase 2 - Aterro São João.

Tabela 20 - Características físico-químicas e taxas do quarto ciclo de tratamento utilizando o sistema R-1 (segunda fase - Aterro São João).

Fase Anóxica

Inicio da etapa anóxica (após alimentação)

\begin{tabular}{|c|c|c|c|c|c|c|c|c|c|c|}
\hline Ciclo & $\mathrm{pH}$ & $\begin{array}{c}\text { Alcalinidade } \\
\text { Total }(\mathrm{mg} / \mathrm{L} \\
\left.\mathrm{CaCO}_{3}\right)\end{array}$ & $\begin{array}{c}\text { SSV } \\
(\mathrm{mg} / \mathrm{L})\end{array}$ & $\begin{array}{l}\text { DBO } \\
(\mathrm{mg} / \mathrm{L})\end{array}$ & $\begin{array}{c}\text { Relação } \\
\mathrm{DBO}_{\text {removidal }} \\
\text { Nitrito- } \\
\text { Nitratoremovido } \\
(\mathrm{Kg} \mathrm{DBO} / \mathrm{Kg} \\
\left.\mathrm{NO}_{3}^{-}, \mathrm{NO}_{2}^{-}\right)\end{array}$ & $\begin{array}{l}\text { Nitrito } \\
(\mathrm{mg} / \mathrm{L})\end{array}$ & $\begin{array}{l}\text { Nitrato } \\
(\mathrm{mg} / \mathrm{L})\end{array}$ & $\begin{array}{l}\mathrm{N}-\mathrm{NH}_{3} \\
(\mathrm{mg} / \mathrm{L})\end{array}$ & $\begin{array}{c}\text { Eficiência } \\
\text { na } \\
\text { remoção } \\
\text { de DBO do } \\
\text { ciclo (\%) }\end{array}$ & $\begin{array}{l}\text { Temperatura } \\
\text { média do } \\
\text { ciclo }\left({ }^{0} \mathrm{C}\right)\end{array}$ \\
\hline
\end{tabular}

\begin{tabular}{ccccccccccc}
\hline 4 & 8,2 & 3750 & 4050 & 143 & 0,88 & 36 & 71 & 120 & 83,9 & 25 \\
\hline \multicolumn{10}{c}{ Final da etapa anóxica = Início da etapa aerada } \\
\hline
\end{tabular}

Taxa de

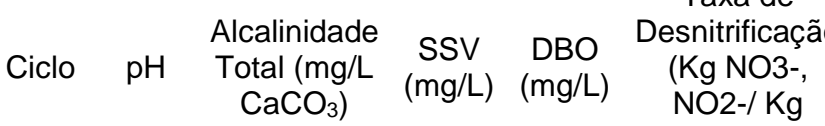
SSV.dia)
Eficiência na

Nitrito Nitrato $\mathrm{N}-\mathrm{NH}_{3}$ Tempo da remoção de $(\mathrm{mg} / \mathrm{L}) \quad(\mathrm{mg} / \mathrm{L}) \quad(\mathrm{mg} / \mathrm{L}) \quad$ etapa $(\mathrm{h}) \quad \mathrm{N}-\mathrm{NO}_{2}{ }^{-} / \mathrm{N}-$ $\mathrm{NO}_{3}^{-}(\%)$

\begin{tabular}{|c|c|c|c|c|c|c|c|c|c|c|}
\hline 4 & 8,5 & 3930 & 4130 & 52 & 0,0104 & 0 & 3 & 110 & 58 & 97,2 \\
\hline \multicolumn{11}{|c|}{ Fase Aerada } \\
\hline \multicolumn{11}{|c|}{ Final da etapa aerada } \\
\hline Ciclo & $\mathrm{pH}$ & $\begin{array}{c}\text { Alcalinidade } \\
\text { Total }(\mathrm{mg} / \mathrm{L} \\
\left.\mathrm{CaCO}_{3}\right)\end{array}$ & $\begin{array}{c}\text { SSV } \\
(\mathrm{mg} / \mathrm{L})\end{array}$ & $\begin{array}{c}\mathrm{DBO} \\
(\mathrm{mg} / \mathrm{L})\end{array}$ & $\begin{array}{l}\text { Tempo da } \\
\text { etapa }(\mathrm{h})\end{array}$ & $\begin{array}{l}\text { Nitrito } \\
\text { (mg/L) }\end{array}$ & $\begin{array}{l}\text { Nitrato } \\
\text { (mg/L) }\end{array}$ & $\begin{array}{l}\mathrm{N}-\mathrm{NH}_{3} \\
(\mathrm{mg} / \mathrm{L})\end{array}$ & $\begin{array}{c}\text { Taxa de } \\
\text { Nitrificação } \\
\text { (Kg N-NH} / \\
\text { Kg } \\
\text { SSV.dia) }\end{array}$ & $\begin{array}{c}\text { Eficiência na } \\
\text { remoção de } \\
\mathrm{N}-\mathrm{NH}_{3}(\%)\end{array}$ \\
\hline
\end{tabular}

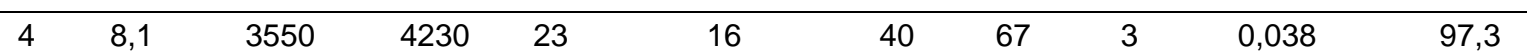




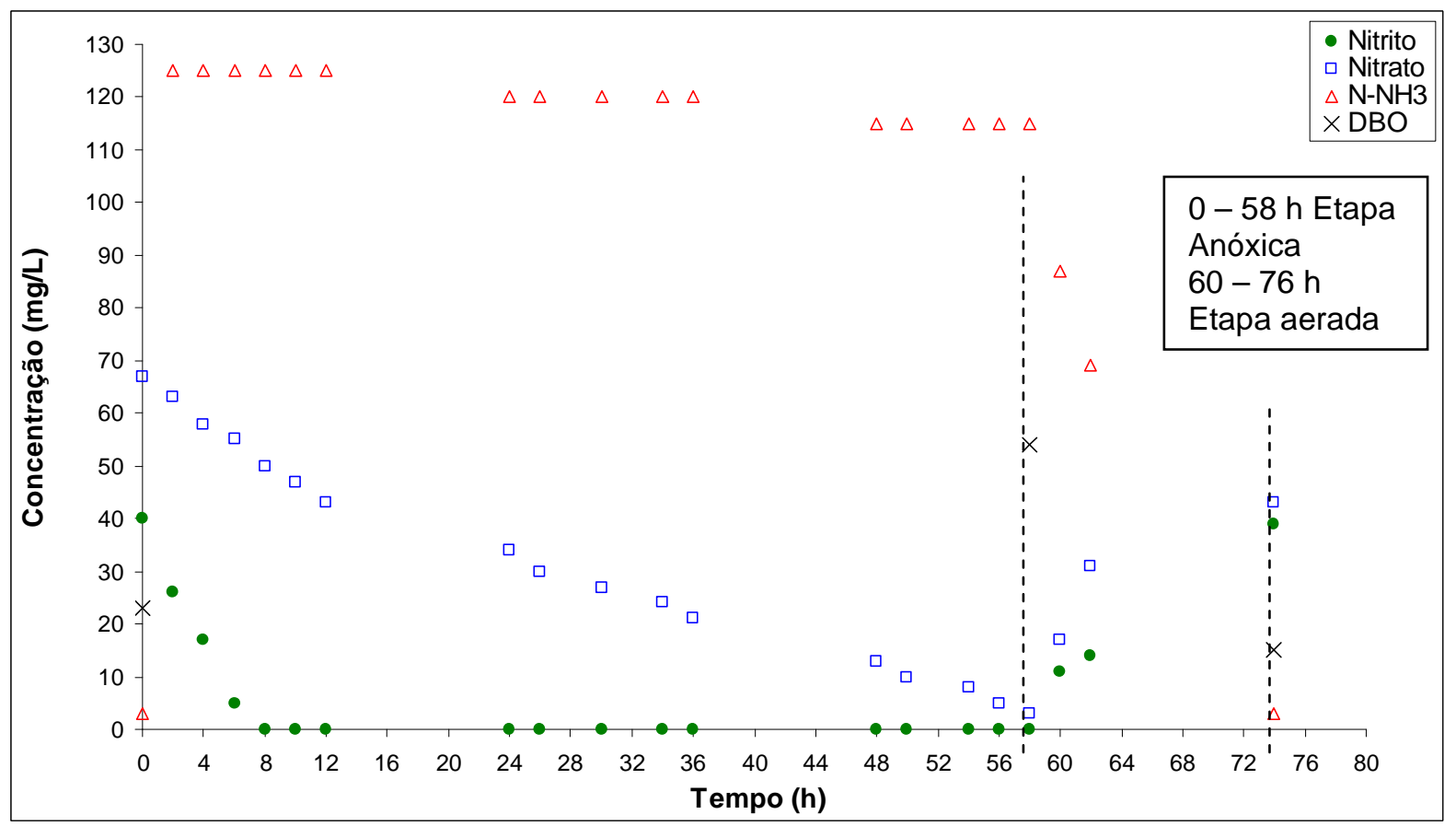

Figura 53 - Perfis temporais das concentrações de DBO, N-NO ${ }_{2}^{-}, \mathrm{N}-\mathrm{NO}_{3}{ }^{-}$e N-NH${ }_{3}+$ durante o quinto ciclo de tratamento do reator R-1/Fase 2 - Aterro São João.

Tabela 21 - Características físico-químicas e taxas do quinto ciclo de tratamento utilizando o sistema R-1 (segunda fase - Aterro São João).

Fase Anóxica

Inicio da etapa anóxica (após alimentação)

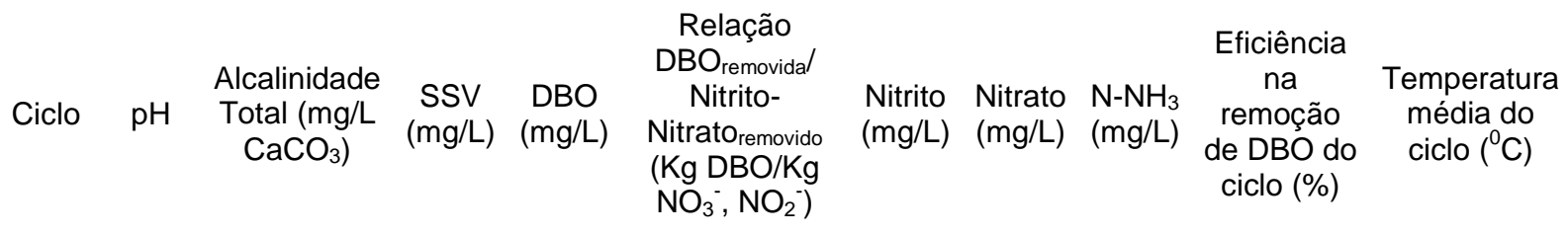

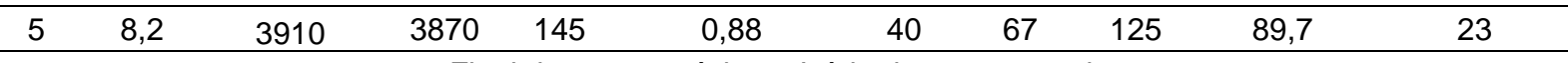

Final da etapa anóxica = Início da etapa aerada

\begin{tabular}{|c|c|c|c|c|c|c|c|c|c|c|}
\hline Ciclo & $\mathrm{pH}$ & $\begin{array}{c}\text { Alcalinidade } \\
\text { Total }(\mathrm{mg} / \mathrm{L} \\
\left.\mathrm{CaCO}_{3}\right)\end{array}$ & $\begin{array}{c}\text { SSV } \\
(\mathrm{mg} / \mathrm{L})\end{array}$ & $\begin{array}{l}\mathrm{DBO} \\
(\mathrm{mg} / \mathrm{L})\end{array}$ & $\begin{array}{c}\text { Taxa de } \\
\text { Desnitrificação } \\
\text { (Kg NO3-, } \\
\text { NO2-/ Kg } \\
\text { SSV.dia) }\end{array}$ & $\begin{array}{l}\text { Nitrito } \\
(\mathrm{mg} / \mathrm{L})\end{array}$ & $\begin{array}{l}\text { Nitrato } \\
(\mathrm{mg} / \mathrm{L})\end{array}$ & $\begin{array}{l}\mathrm{N}-\mathrm{NH}_{3} \\
(\mathrm{mg} / \mathrm{L})\end{array}$ & $\begin{array}{l}\text { Tempo da } \\
\text { etapa (h) }\end{array}$ & 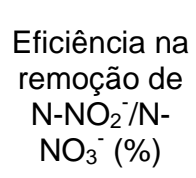 \\
\hline
\end{tabular}

\begin{tabular}{|c|c|c|c|c|c|c|c|c|c|c|}
\hline 5 & 8,6 & 4100 & 3910 & 54 & 0,0110 & 0 & 3 & 115 & 58 & 97,2 \\
\hline \multicolumn{11}{|c|}{ Fase Aerada } \\
\hline \multicolumn{11}{|c|}{ Final da etapa aerada } \\
\hline Ciclo & $\mathrm{pH}$ & $\begin{array}{c}\text { Alcalinidade } \\
\text { Total }(\mathrm{mg} / \mathrm{L} \\
\left.\mathrm{CaCO}_{3}\right)\end{array}$ & $\begin{array}{c}\text { SSV } \\
(\mathrm{mg} / \mathrm{L})\end{array}$ & $\begin{array}{l}\mathrm{DBO} \\
(\mathrm{mg} / \mathrm{L})\end{array}$ & $\begin{array}{l}\text { Tempo da } \\
\text { etapa (h) }\end{array}$ & $\begin{array}{l}\text { Nitrito } \\
\text { (mg/L) }\end{array}$ & $\begin{array}{l}\text { Nitrato } \\
(\mathrm{mg} / \mathrm{L})\end{array}$ & $\begin{array}{l}\mathrm{N}-\mathrm{NH}_{3} \\
(\mathrm{mg} / \mathrm{L})\end{array}$ & $\begin{array}{c}\text { Taxa de } \\
\text { Nitrificação } \\
(\mathrm{Kg} \mathrm{N}- \\
\mathrm{NH}_{3} / \mathrm{Kg} \\
\text { SSV.dia) }\end{array}$ & $\begin{array}{c}\text { Eficiência na } \\
\text { remoção de } \\
\mathrm{N}-\mathrm{NH}_{3}(\%)\end{array}$ \\
\hline
\end{tabular}

$\begin{array}{lllllllllll}5 & 8,2 & 3830 & 3690 & 15 & 16 & 39 & 43 & 3 & 0,046 & 97,4\end{array}$


Nota-se através das figuras 51 a 54 acima que houve uma predominância na formação de nitrato durante a fase aerada do ciclo. Mesmo com a predominância de nitrato, a concentração de nitrito foi aumentando no decorrer dos ciclos.

Outro fato relevante ocorrido durante todos os ciclos da fase 2 bem como da fase 1 foi que, a concentração de alcalinidade da massa líquida aumentou durante a fase anóxica (tabela 18 a 21) comprovando assim, a recuperação de alcalinidade durante esta fase como preconiza VAN HAANDEL; MARAIS, (1999). A recuperação média de alcalinidade durante a etapa anóxica da primeira fase da pesquisa foi de 1,41 $\left(\mathrm{mg} / \mathrm{L} \mathrm{CaCO}{ }_{3}\right) /\left(\mathrm{mg} / \mathrm{L} \mathrm{N}-\mathrm{NO}_{2}{ }^{-} / \mathrm{N}^{-} \mathrm{NO}_{3}{ }^{-}\right)$, já na fase 2 a recuperação média foi de 2,36 $\left(\mathrm{mg} / \mathrm{L} \mathrm{CaCO}{ }_{3}\right) /\left(\mathrm{mg} / \mathrm{L} \mathrm{N}-\mathrm{NO}_{2}{ }^{-} / \mathrm{N}^{-N}{ }_{3}{ }^{-}\right)$. O aumento da alcalinidade bem como do $\mathrm{pH}$ é de suma importância para a etapa seguinte do ciclo (aerada) já que, quanto maior o $\mathrm{pH}$ e a alcalinidade maior será a capacidade de tamponamento do sistema durante a etapa aeróbia evitando assim, quedas muito acentuadas do $\mathrm{pH}$.

A concentração de amônia livre nos 4 últimos ciclos da fase 2 ficaram acima dos valores considerados inibitórios para as bactérias oxidantes de nitrito, condição essa que deveria favorecer o acúmulo de nitrito durante a fase aerada. É importante ressaltar que houve sim um acúmulo de nitrito na fase aeróbia, porém, a conversão de nitrogênio amoniacal em nitrito não foi completa, além disso, o gasto de alcalinizante durante a etapa aeróbia, para manter o pH da massa líquida acima de 8,3, não era uma condição operacional desejável.

Os valores da concentração de amônia livre durante os quatro últimos ciclos da etapa aeróbia ficaram entre:

- $\quad 1^{0}$ ciclo $=12,04 \mathrm{mg} / \mathrm{L}$ (inicio etapa aerada) e $0,24 \mathrm{mg} / \mathrm{L}$ (final etapa aerada);

- $2^{0}$ ciclo $=9,48 \mathrm{mg} / \mathrm{L}$ (inicio etapa aerada) e $0,18 \mathrm{mg} / \mathrm{L}$ (final etapa aerada);

- $3^{0} \mathrm{ciclo}=12,04 \mathrm{mg} / \mathrm{L}$ (inicio etapa aerada) e 0,24 mg/L (final etapa aerada);

- $4^{0}$ ciclo $=10,98 \mathrm{mg} / \mathrm{L}$ (inicio etapa aerada) e $0,26 \mathrm{mg} / \mathrm{L}$ (final etapa aerada). 


\subsubsection{FASE O3 - ALIMENTAÇÃO DO SISTEMA COM LIXIVIADO PRÉ-TRATADO ("STRIPPING" DE AMÔNIA ATÉ A CONCENTRAÇÃO DE APROXIMADAMENTE 900 $M G / L)$}

Assim como ocorrido na primeira fase da pesquisa, na segunda fase os resultados não foram os compatíveis com os objetivos da pesquisa, ou seja, não foi atingida a eficiência desejada para a conversão do nitrogênio amoniacal em nitrito (acúmulo de nitrito).

Como supostamente uma das causas do não acúmulo completo de nitrito foi a queda brusca do $\mathrm{pH}$ durante a etapa aeróbia, optou-se por diminuir o tempo desta etapa; para isso, foi reduzido a concentração inicial de nitrogênio amoniacal do lixiviado utilizado na alimentação do sistema para aproximadamente $900 \mathrm{mg} / \mathrm{L}$. Como relatado anteriormente, para se chegar a essa concentração de nitrogênio amoniacal realizado "stripping" do lixiviado.

A figura 55 traz os perfis temporais das concentrações de nitrito, nitrato, $\mathrm{N}-\mathrm{NH}_{3} \mathrm{e}$ DBO durante os dois primeiros ciclos da terceira fase da pesquisa.

Nota-se através da figura 55 que na fase aerada do ciclo mesmo havendo uma formação de nitrato, a predominância foi de nitrito indicando assim uma melhor adaptação do sistema às condições operacionais.

Pela primeira vez na pesquisa não houve a necessidade da adição de alcalinizante durante a etapa aeróbia do ciclo já que, o pH não decaiu a um valor muito abaixo de 8,3 .

Os valores de amônia livre durante os dois primeiros ciclos variaram entre:

- $1^{0}$ ciclo = 16,8 mg/L (inicio etapa aerada) 0,23mg/L (final etapa aerada);

- $\quad 2^{0}$ ciclo $=14,26 \mathrm{mg} / \mathrm{L}$ (inicio etapa aerada) $0,37 \mathrm{mg} / \mathrm{L}$ (final etapa aerada)

Nota-se que os valores de amônia livre tanto do primeiro como do segundo estão dentro da faixa considerada inibidora das bactérias oxidantes de nitrito, ou seja, a condição estava favorável ao acúmulo de nitrito. A tabela 22 traz as características físico-químicas e taxas determinadas durante o ciclo 1 e 2 desta fase. 
Tabela 22 - Características físico-químicas e taxas dos 2 primeiros ciclos de tratamento utilizando o sistema R-1 (terceira fase).

\begin{tabular}{|c|c|c|c|c|c|c|c|c|c|c|}
\hline \multicolumn{11}{|c|}{ Fase Anóxica } \\
\hline \multicolumn{11}{|c|}{ Inicio da etapa anóxica (após alimentação) } \\
\hline Ciclo & $\mathrm{pH}$ & $\begin{array}{c}\text { Alcalinidade } \\
\text { Total }(\mathrm{mg} / \mathrm{L} \\
\left.\mathrm{CaCO}_{3}\right)\end{array}$ & $\begin{array}{c}\text { SSV } \\
\text { (mg/L) }\end{array}$ & $\begin{array}{c}\text { DBO } \\
(\mathrm{mg} / \mathrm{L})\end{array}$ & $\begin{array}{c}\text { Relação } \\
\mathrm{DBO}_{\text {removidal }} \\
\text { Nitrito- } \\
\text { Nitrato removido } \\
\left(\mathrm{Kg} \mathrm{DBO}^{-} \mathrm{Kg}\right. \\
\left.\mathrm{NO}_{3}^{-}, \mathrm{NO}_{2}^{-}\right)\end{array}$ & $\begin{array}{l}\text { Nitrito } \\
\text { (mg/L) }\end{array}$ & $\begin{array}{l}\text { Nitrato } \\
\text { (mg/L) }\end{array}$ & $\begin{array}{l}\mathrm{N}-\mathrm{NH}_{3} \\
\text { (mg/L) }\end{array}$ & $\begin{array}{c}\text { Eficiência } \\
\text { na } \\
\text { remoção } \\
\text { de DBO do } \\
\text { ciclo (\%) }\end{array}$ & $\begin{array}{l}\text { Temperatura } \\
\text { média do } \\
\text { ciclo }\left({ }^{0} \mathrm{C}\right)\end{array}$ \\
\hline 1 & 8,5 & 3530 & 4250 & 107 & 0,86 & 59 & 22 & 93 & 86,0 & 24 \\
\hline 2 & 8,4 & 3640 & 3620 & 103 & 0,84 & 69 & 14 & 94 & 85,4 & 25 \\
\hline \multicolumn{11}{|c|}{ Final da etapa anóxica = Início da etapa aerada } \\
\hline Ciclo & $\mathrm{pH}$ & $\begin{array}{c}\text { Alcalinidade } \\
\text { Total }(\mathrm{mg} / \mathrm{L} \\
\left.\mathrm{CaCO}_{3}\right)\end{array}$ & $\begin{array}{c}\text { SSV } \\
\text { (mg/L) }\end{array}$ & $\begin{array}{c}\mathrm{DBO} \\
(\mathrm{mg} / \mathrm{L})\end{array}$ & $\begin{array}{c}\text { Taxa de } \\
\text { Desnitrificação } \\
\text { (Kg NO3-, } \\
\text { NO2-/ Kg } \\
\text { SSV.dia) }\end{array}$ & $\begin{array}{l}\text { Nitrito } \\
\text { (mg/L) }\end{array}$ & $\begin{array}{l}\text { Nitrato } \\
\text { (mg/L) }\end{array}$ & $\begin{array}{l}\mathrm{N}-\mathrm{NH}_{3} \\
(\mathrm{mg} / \mathrm{L})\end{array}$ & $\begin{array}{l}\text { Tempo da } \\
\text { etapa (h) }\end{array}$ & $\begin{array}{c}\text { Eficiência na } \\
\text { remoção de } \\
{\mathrm{N}-\mathrm{NO}_{2}^{-} / \mathrm{N}-}_{\mathrm{NO}_{3}^{-}(\%)}\end{array}$ \\
\hline 1 & 8,7 & 3680 & 4260 & 40 & 0,0061 & 0 & 3 & 88 & 72 & 96,3 \\
\hline 2 & 8,7 & 3890 & 4070 & 35 & 0,0066 & 2 & 0 & 88 & 72 & 97,6 \\
\hline \multicolumn{11}{|c|}{ Fase Aerada } \\
\hline \multicolumn{11}{|c|}{ Final da etapa aerada } \\
\hline Ciclo & $\mathrm{pH}$ & $\begin{array}{c}\text { Alcalinidade } \\
\text { Total }(\mathrm{mg} / \mathrm{L} \\
\left.\mathrm{CaCO}_{3}\right)\end{array}$ & $\begin{array}{c}\text { SSV } \\
\text { (mg/L) }\end{array}$ & $\begin{array}{c}\text { DBO } \\
\text { (mg/L) }\end{array}$ & $\begin{array}{l}\text { Tempo da } \\
\text { etapa }(\mathrm{h})\end{array}$ & $\begin{array}{l}\text { Nitrito } \\
\text { (mg/L) }\end{array}$ & $\begin{array}{l}\text { Nitrato } \\
\text { (mg/L) }\end{array}$ & $\begin{array}{l}\mathrm{N}-\mathrm{NH}_{3} \\
\text { (mg/L) }\end{array}$ & $\begin{array}{c}\text { Taxa de } \\
\text { Nitrificação } \\
\text { (Kg N-NH } / \\
\text { Kg } \\
\text { SSV.dia) }\end{array}$ & $\begin{array}{c}\text { Eficiência na } \\
\text { remoção de } \\
\mathrm{N}-\mathrm{NH}_{3}(\%)\end{array}$ \\
\hline 1 & 8,3 & 3360 & 4250 & 15 & 10 & 69 & 14 & 2 & 0,049 & 97,7 \\
\hline 2 & 8,3 & 3570 & 3780 & 15 & 10 & 82 & 0 & 3 & 0,054 & 96,6 \\
\hline
\end{tabular}

Nota-se através da tabela 22 que a inibição da nitratação foi total no ciclo 2 ou seja, quase todo o nitrogênio amoniacal do lixiviado bruto foi oxidado a nitrito. A eficiência na conversão de nitrogênio amoniacal para nitrito no final do ciclo foi acima de $95 \%$. A eficiência na remoção de DBO também ficou acima de $85 \%$ nos dois ciclos.

Outro dado relevante referente aos dois ciclos de tratamento foi que apesar de a quantidade de nitrito formada, em comparação as fases anteriores, ser menor nestes ciclos, a fase anóxica foi relativamente longa. A possível explicação para esse longo tempo da fase anóxica foi à baixa disponibilidade de matéria orgânica facilmente biodegradável. Como relatado anteriormente o processo de "stripping" provocou uma diminuição na concentração de matéria orgânica disponível para a redução do nitrito sobrando assim, uma grande quantidade de compostos refratários que não são facilmente assimilados pelos microrganismos tendo como conseqüência, os longos tempos da etapa anóxica. 


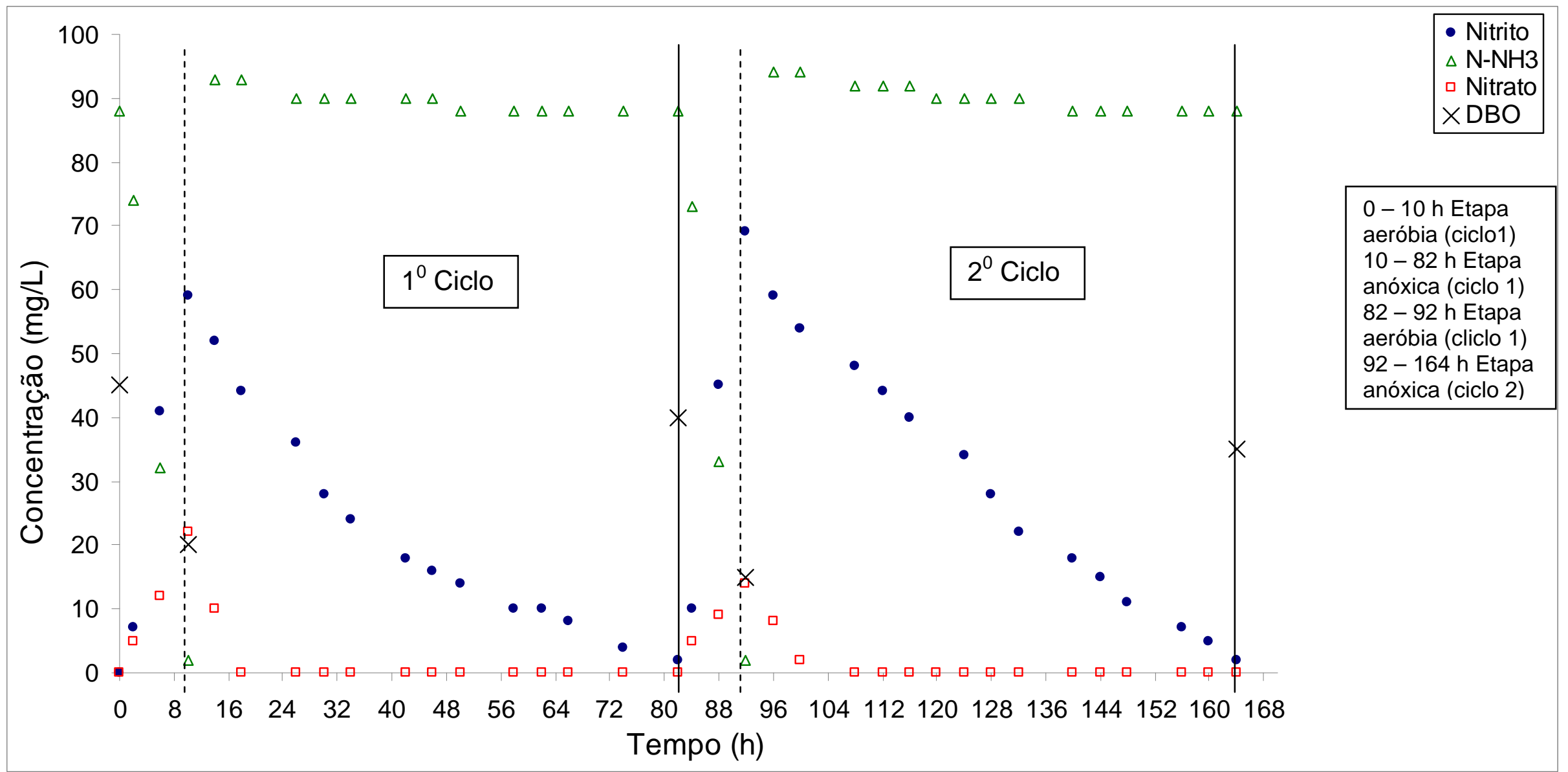

Figura 54 - Perfis temporais das concentrações de $\mathrm{DBO}, \mathrm{N}-\mathrm{NO}_{2}^{-}, \mathrm{N}-\mathrm{NO}_{3}^{-}$e $\mathrm{N}-\mathrm{NH}_{3}+$ durante os dois primeiros ciclos de tratamento do reator $\mathrm{R}$ 1/Fase 3 - Aterro Bandeirantes. 
A partir do segundo ciclo de tratamento desta fase o sistema entrou em equilíbrio sendo que, todos os tempos de cada etapa do ciclo foram praticamente constantes (10 h de etapa anóxica e 72h etapa aerada). Não houve mais a necessidade de adição de alcalinizante em nenhum dos ciclos desta fase já que, a alcalinidade provinda do lixiviado bruto associada com a redução do tempo da etapa aerada propiciou que o $\mathrm{pH}$ da massa líquida no final da etapa se mantivesse sempre acima ou igual a 8,3. Outro fenômeno que contribuiu para a manutenção do pH da massa líquida acima de 8,3 durante a fase aerada foi a recuperação da alcalinidade durante a etapa anóxica do ciclo. A alcalinidade recuperada propiciou um maior tamponamento da massa líquida evitando quedas bruscas no pH. A figura 56 demonstra o perfil de variação da alcalinidade durante a etapa anóxica do segundo ciclo de tratamento desta fase. A recuperação média de alcalinidade durante os 20 ciclos dessa fase foi de $1,92\left(\mathrm{mg} / \mathrm{L} \mathrm{CaCO}{ }_{3}\right) /\left(\mathrm{mg} / \mathrm{LN}-\mathrm{NO}_{2}{ }^{-} / \mathrm{N}^{-\mathrm{NO}_{3}}{ }^{-}\right)$

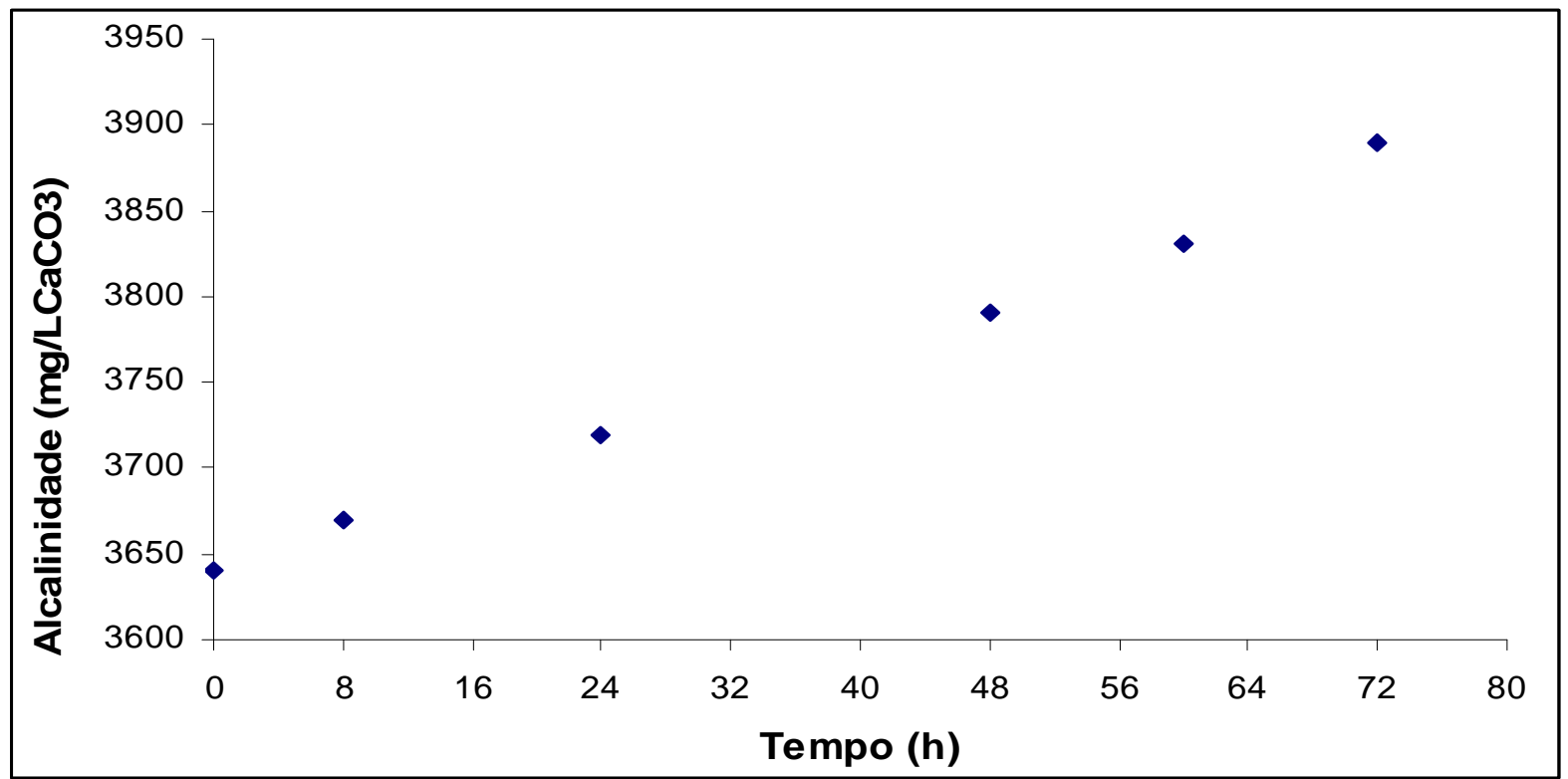

Figura 55 - Perfil da concentração de alcalinidade durante a etapa anóxica do segundo ciclo de tratamento - Fase3

Esta fase foi a mais duradoura entre as 4 da pesquisa, sendo executados 20 ciclos de tratamento com comportamento do sistema praticamente constante ao longo destes ciclos. A figura 57 traz o perfil de concentração do nitrito durante os 10 primeiros ciclos de tratamento desta fase. Já a figura 58 demonstra o perfil de concentração para os dez ciclos restantes da fase. Os ciclos não foram "plotados" no mesmo gráfico, pois os horários de coleta mudaram a partir do décimo ciclo desta 
fase. A figura 60 traz o perfil das concentrações médias de nitrito durante a fase anóxica relativa aos 10 primeiros ciclos de tratamento já a figura 61 traz o perfil para os últimos 10 ciclos de tratamento. 


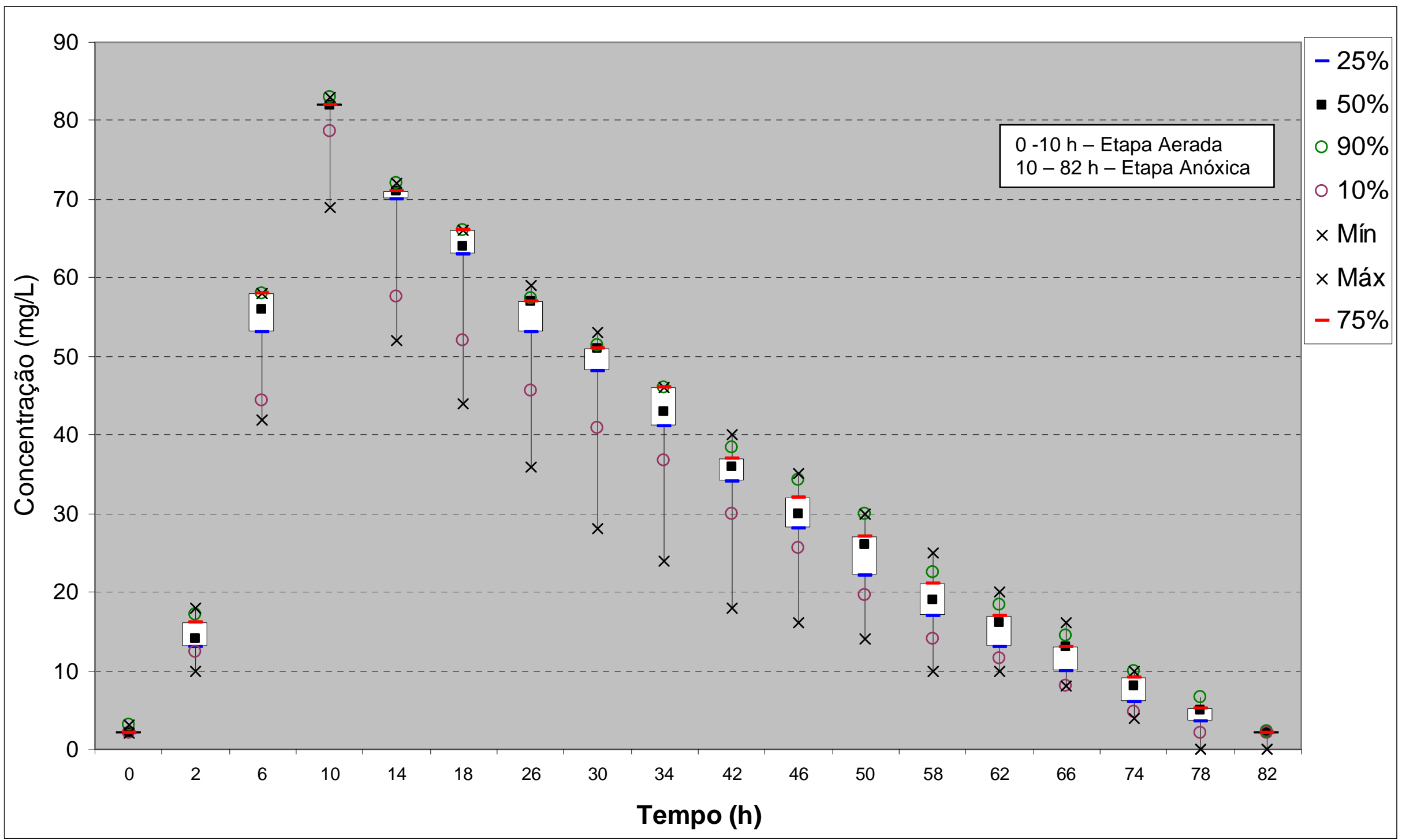

Figura 56 - Perfis das concentrações de $\mathrm{N}^{-\mathrm{NO}_{2}}{ }^{-}$durante os 10 primeiros ciclos de tratamento - Fase 3 


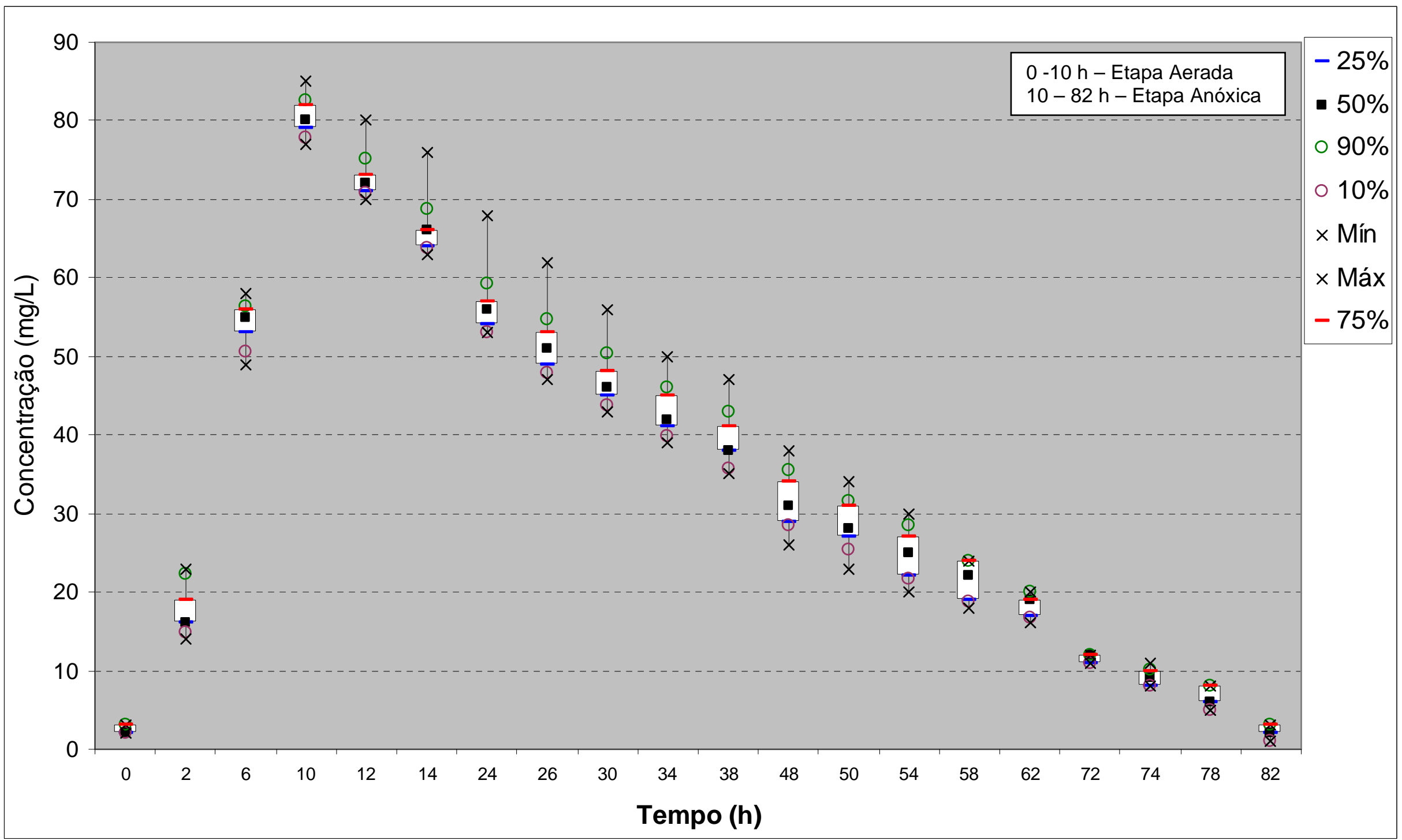

Figura 57 - Perfis das concentrações de $\mathrm{N}^{-\mathrm{NO}_{2}}{ }^{-}$durante os 10 últimos ciclos de tratamento - Fase 3 


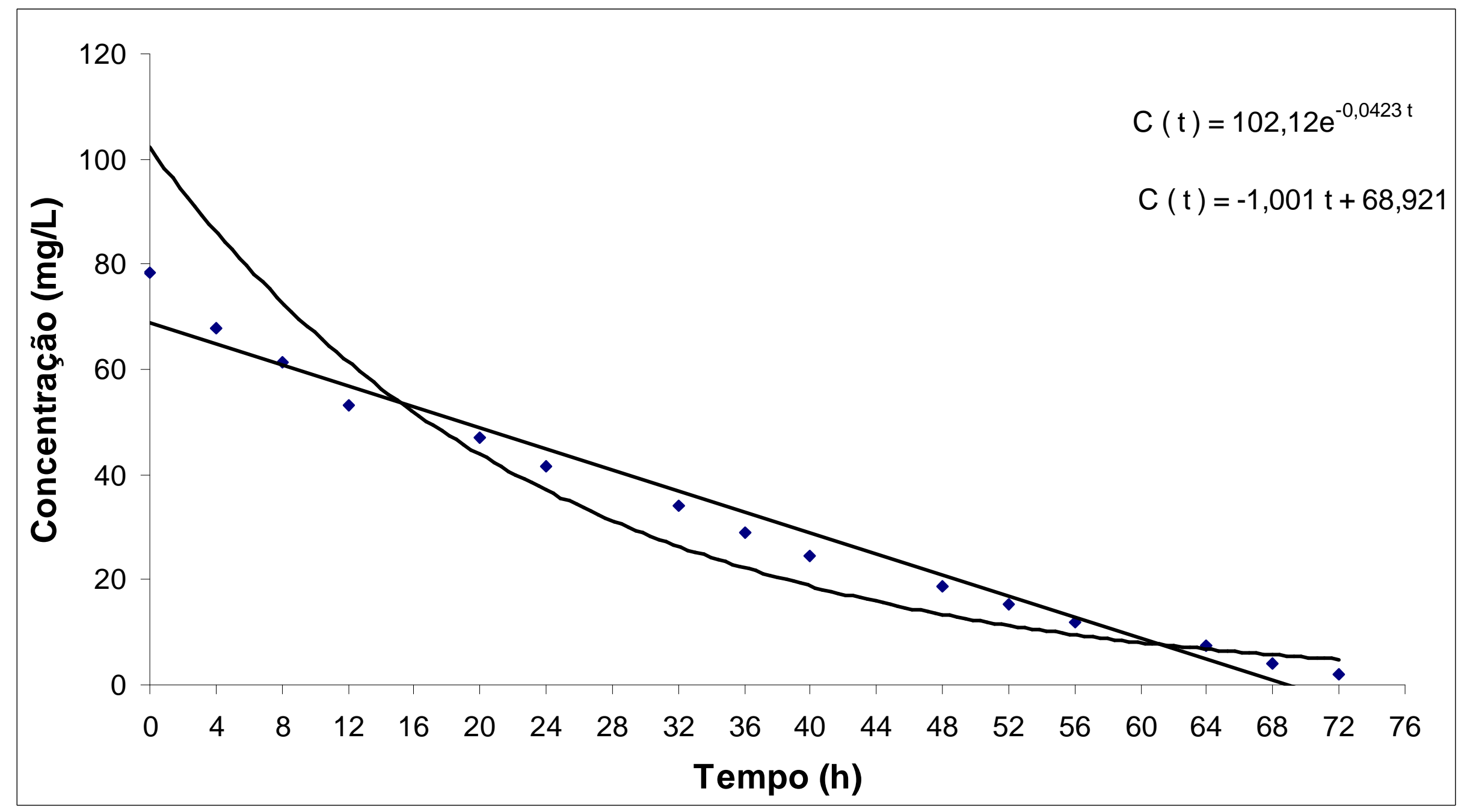

Figura 58 - Concentrações médias de $\mathrm{N}_{-} \mathrm{NO}_{2}{ }^{-}$durante a etapa anóxica dos 10 primeiros ciclos de tratamento do sistema R-1 - Fase 3. 


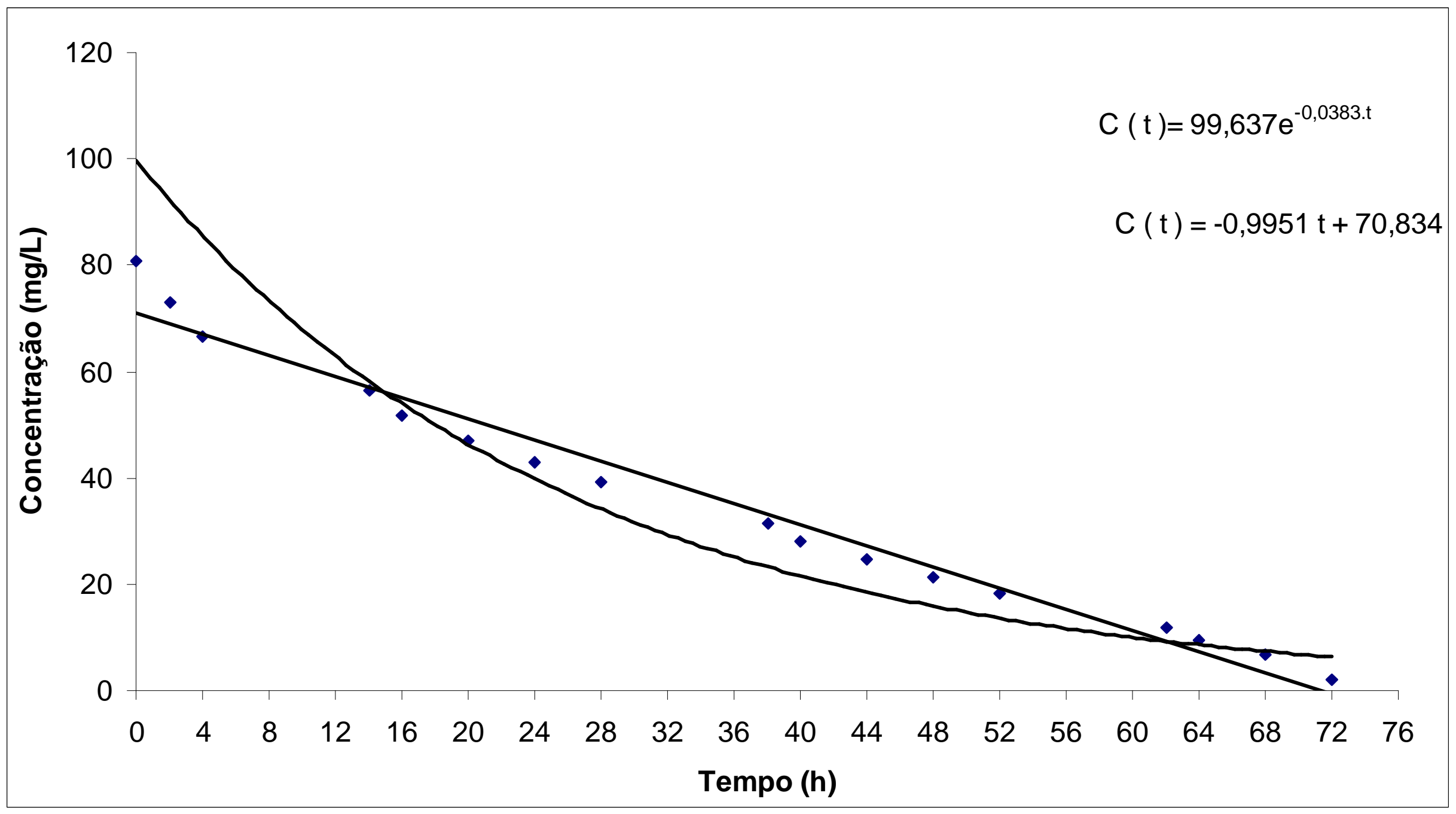

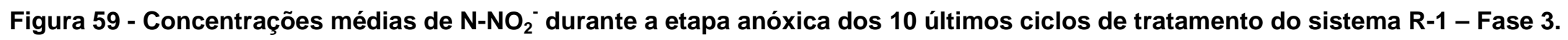


As reações de redução do nitrito na etapa anóxica estão representadas pela figura 59 e 60 sendo que, esta redução pode ser representada por uma equação de ordem zero (uma reta) ou uma equação de ordem 1 (exponencial). Neste caso em específico a reação de redução do nitrito foi representada pelas duas equações, pois em alguns ciclos a reação era melhor representada por uma equação de ordem $0 \mathrm{e}$ em outros ciclos por uma equação de $1^{\underline{a}}$ ordem. Através das figuras 60 e 61 este fato pode ser melhor observado.Nestas figuras estão "plotados" todos os ciclos de tratamento sendo possível observar que alguns ciclos são melhor representados por equações de ordem zero e outros por equações de $1^{\text {a }}$ ordem.

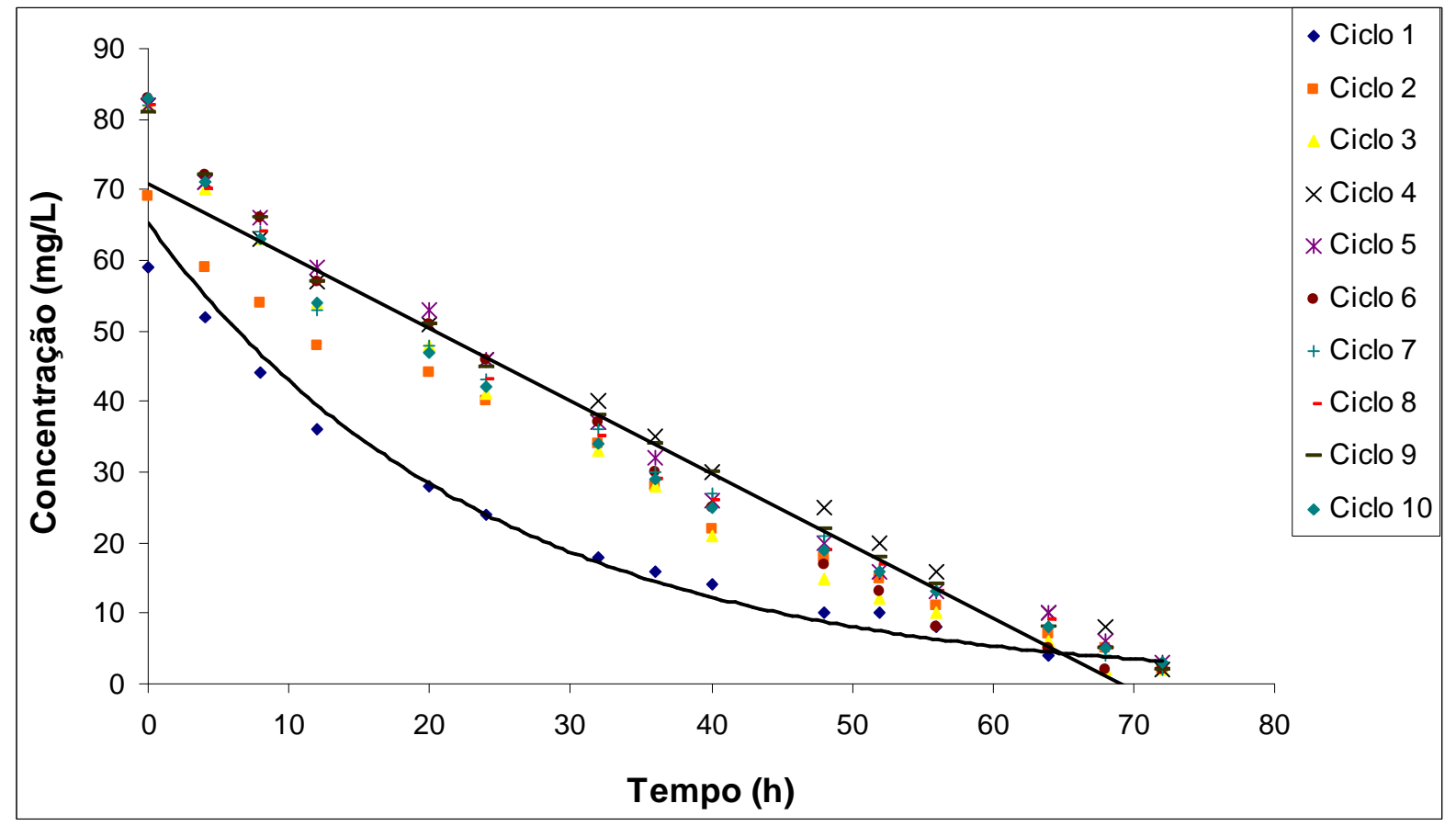

Figura 60 - Variação da concentração de $\mathrm{N}^{-\mathrm{NO}_{2}}{ }^{-}$durante a fase anóxica dos 10 primeiros ciclos de tratamento do reator R-1 - fase 3.

Nota-se através das figuras 57 e 58 que a queda na concentração de nitrito foi mais acentuada nas primeiras horas de ciclo. No inicio do ciclo a disponibilidade de matéria orgânica biodegradável era maior, ou seja, matéria orgânica mais facilmente assimilada pelos microrganismos responsáveis pela redução do nitrito. 


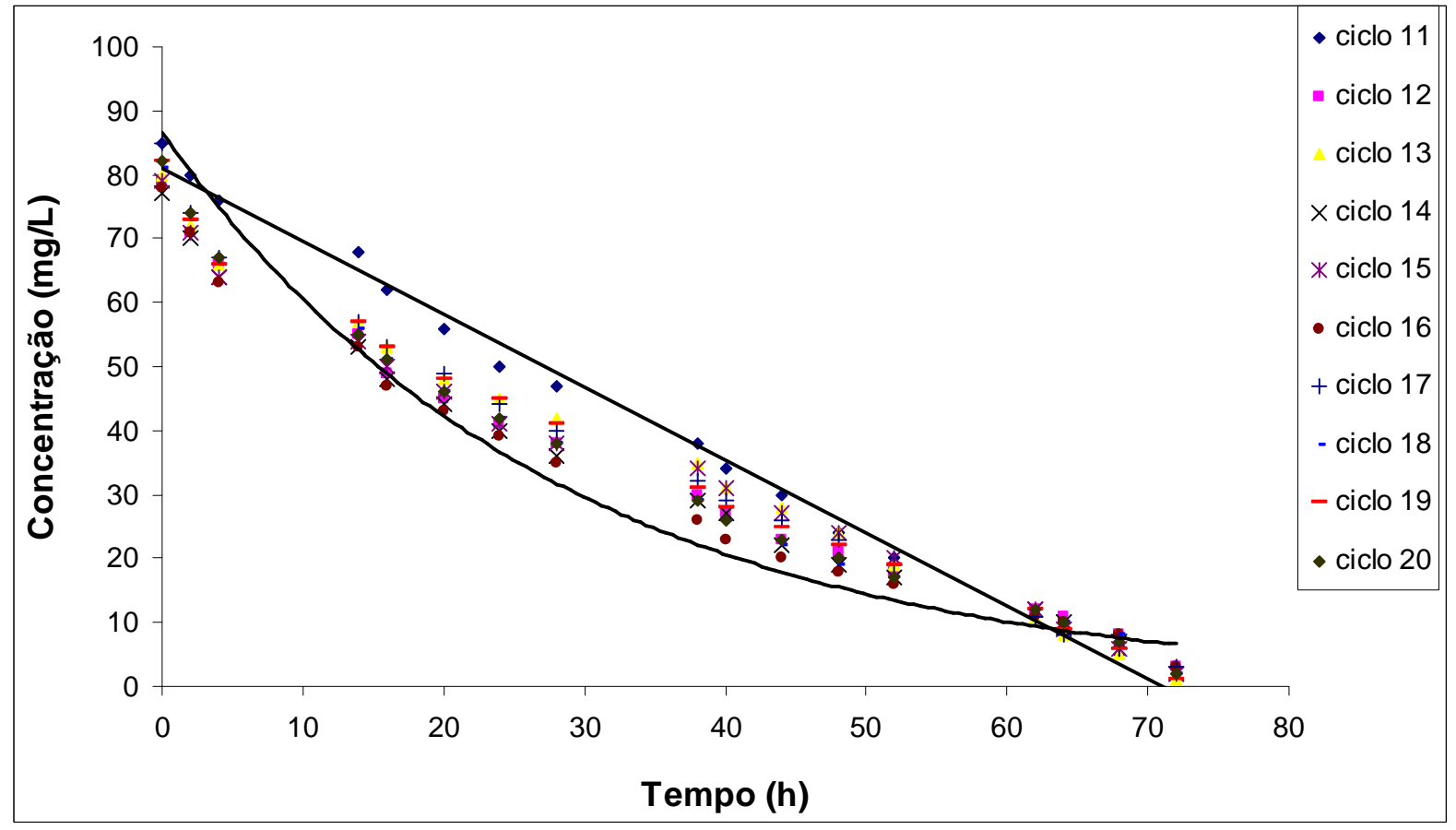

Figura 61 - Variação da concentração de N-NO2- durante a fase anóxica dos 10 ultimos ciclos de tratamento do reator R-1 - fase 3.

O tempo da etapa anóxica foi condicionado pela disponibilidade de matéria orgânica para a redução do nitrito. A matéria orgânica (DQO, DBO, COT) reduzida durante o processo de "stripping" pode ter limitado o tempo da etapa anóxica do ciclo.

Na figura 58 a queda na concentração de nitrito no início da etapa anóxica é mais evidente já que os intervalos de tempo de coleta para estes ciclos, no inicio da fase anóxica, foram reduzidos.

Comparando-se as figuras 57 e 58 nota-se que a distribuição das concentrações de nitrito foi mais uniforme, para cada intervalo de tempo, nos últimos 10 ciclos de tratamento, isso demonstra que o sistema entrou em regime de equilíbrio ao longo do tempo.

A amônia livre durante esta fase da pesquisa variou entre 25,02 mg/l (inicio etapa aerada) e 0,162 mg/l (final da fase aerada). Estas concentrações, segundo Anthonisen et al. (1976), são inibitórios para as bactérias que oxidam nitrito, ou seja, esta condição associada a manutenção do $\mathrm{pH}$ pode ter favorecido o acúmulo de 
nitrito durante a etapa aerada. A tabela 23 traz as características físico-químicas e as taxas referentes aos 20 ciclos de tratamento. Já a figura 63 traz o perfil das concentrações de COT durante os últimos 10 ciclos de tratamento.

Mesmo com longos tempos da etapa anóxica a redução de nitrito a nitrato (quando formado) teve uma eficiência acima de 95\%.

É importante ressaltar que em todas as fases da pesquisa foram executadas análises de DQO durante os ciclos, porém estes dados não foram acrescentados à pesquisa, pois os mesmos não são consistentes já que, a análise DQO durante os ciclos, principalmente na etapa aerada, é passível de muitas interferências (nitrito, sulfetos, cloretos, etc.) sendo que, os valores foram incompatíveis com a operação do sistema.

Tabela 23 - Características físico-químicas e taxas referentes aos 20 ciclos de tratamento utilizando o sistema R-1 (terceira fase).

\begin{tabular}{|c|c|c|c|c|c|c|c|c|c|c|}
\hline \multicolumn{11}{|c|}{ Fase Anóxica } \\
\hline \multicolumn{11}{|c|}{ Inicio da etapa anóxica (após alimentação) } \\
\hline Ciclo & $\mathrm{pH}$ & $\begin{array}{c}\text { Alcalinidade } \\
\text { Total }(\mathrm{mg} / \mathrm{L} \\
\left.\mathrm{CaCO}_{3}\right)\end{array}$ & $\begin{array}{c}\text { SSV } \\
\text { (mg/L) }\end{array}$ & $\begin{array}{c}\text { DBO } \\
(\mathrm{mg} / \mathrm{L})\end{array}$ & $\begin{array}{c}\text { Relação } \\
\mathrm{DBO}_{\text {removidal }} \\
\text { Nitrito- } \\
\text { Nitrato } \\
\text { (mg } \\
\mathrm{DBO} / \mathrm{mg}^{-} \\
\left.\mathrm{NO}_{3}^{-}, \mathrm{NO}_{2}^{-}\right)\end{array}$ & $\begin{array}{l}\text { Nitrito } \\
\text { (mg/L) }\end{array}$ & $\begin{array}{l}\text { Nitrato } \\
(\mathrm{mg} / \mathrm{L})\end{array}$ & $\begin{array}{l}\mathrm{N}-\mathrm{NH}_{3} \\
(\mathrm{mg} / \mathrm{L})\end{array}$ & $\begin{array}{c}\text { Eficiência } \\
\text { na } \\
\text { remoção } \\
\text { de DBO } \\
\text { do ciclo } \\
(\%)\end{array}$ & $\begin{array}{c}\text { Temperatura } \\
\text { média do } \\
\text { ciclo }\left({ }^{0} \mathrm{C}\right)\end{array}$ \\
\hline 1 & 8,5 & 3530 & 4250 & 107 & 0,86 & 59 & 22 & 93 & 86,0 & 24 \\
\hline 2 & 8,4 & 3640 & 3620 & 103 & 0,84 & 69 & 14 & 94 & 85,4 & 21 \\
\hline 3 & 8,3 & 2920 & 4210 & 107 & 0,90 & 82 & 0 & 94 & 86,0 & 25 \\
\hline 4 & 8,4 & 2960 & 4180 & 110 & 0,88 & 82 & 0 & 94 & 81,8 & 23 \\
\hline 5 & 8,3 & 2840 & 3890 & 109 & 0,90 & 82 & 0 & 94 & 86,2 & 25 \\
\hline 6 & 8,3 & 3000 & 3880 & 105 & 0,84 & 83 & 0 & 93 & 85,7 & 26 \\
\hline 7 & 8,4 & 3320 & 3990 & 97 & 0,84 & 82 & 0 & 94 & 84,5 & 24 \\
\hline 8 & 8,5 & 3180 & 3730 & 96 & 0,80 & 82 & 0 & 93 & 86,5 & 20 \\
\hline 9 & 8,3 & 3450 & 4030 & 109 & 0,94 & 83 & 0 & 94 & 90,8 & 22 \\
\hline 10 & 8,3 & 3380 & 4150 & 105 & 0,83 & 81 & 0 & 93 & 83,8 & 21 \\
\hline 11 & 8,4 & 3610 & 4180 & 101 & 0,73 & 85 & 0 & 93 & 85,1 & 22 \\
\hline 12 & 8,3 & 3550 & 4000 & 95 & 0,79 & 79 & 0 & 94 & 84,2 & 23 \\
\hline 13 & 8,3 & 3330 & 4320 & 105 & 0,88 & 80 & 0 & 93 & 85,7 & 24 \\
\hline 14 & 8,3 & 3400 & 3810 & 104 & 0,85 & 77 & 0 & 93 & 84,6 & 24 \\
\hline 15 & 8,4 & 3450 & 4250 & 99 & 0,84 & 79 & 0 & 94 & 84,8 & 25 \\
\hline 16 & 8,4 & 3350 & 3900 & 98 & 0,89 & 78 & 0 & 93 & 84,7 & 22 \\
\hline 17 & 8,3 & 2980 & 3750 & 100 & 0,80 & 85 & 0 & 95 & 90,0 & 23 \\
\hline 18 & 8,4 & 3110 & 4120 & 95 & 0,76 & 81 & 0 & 94 & 89,5 & 23 \\
\hline 19 & 8,3 & 3210 & 4060 & 107 & 0,84 & 82 & 0 & 94 & 86,0 & 24 \\
\hline 20 & 8,3 & 2870 & 3980 & 110 & 0,85 & 82 & 0 & 94 & 90,9 & 25 \\
\hline
\end{tabular}


Final da etapa anóxica = Início da etapa aerada

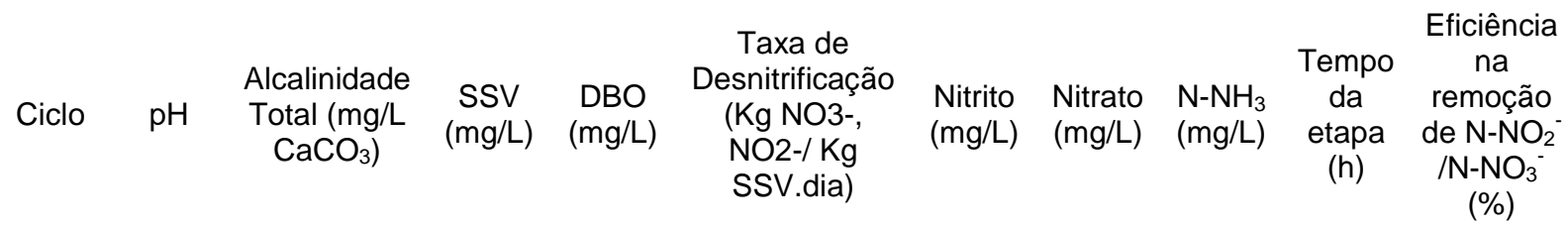

\begin{tabular}{ccccccccccc}
\hline 1 & 8,7 & 3680 & 4260 & 40 & 0,0061 & 0 & 3 & 88 & 72 & 96,3 \\
\hline 2 & 8,7 & 3890 & 4070 & 35 & 0,0066 & 2 & 0 & 88 & 72 & 97,6 \\
\hline 3 & 8,7 & 3180 & 4220 & 35 & 0,0063 & 2 & 0 & 88 & 72 & 97,6 \\
\hline 4 & 8,6 & 3100 & 4200 & 40 & 0,0063 & 2 & 0 & 88 & 72 & 97,6 \\
\hline 5 & 8,7 & 2960 & 4280 & 38 & 0,0062 & 3 & 0 & 88 & 72 & 96,3 \\
\hline 6 & 8,6 & 3150 & 3980 & 37 & 0,0068 & 2 & 0 & 87 & 72 & 97,6 \\
\hline 7 & 8,7 & 3480 & 4150 & 30 & 0,0064 & 2 & 0 & 88 & 72 & 97,6 \\
\hline 8 & 8,7 & 3270 & 4050 & 32 & 0,0066 & 2 & 0 & 88 & 72 & 97,6 \\
\hline 9 & 8,6 & 3590 & 4110 & 33 & 0,0066 & 2 & 0 & 87 & 72 & 97,6 \\
\hline 10 & 8,7 & 3510 & 4310 & 40 & 0,0060 & 3 & 0 & 87 & 72 & 96,3 \\
\hline 11 & 8,7 & 3730 & 4110 & 40 & 0,0067 & 2 & 0 & 87 & 72 & 97,6 \\
\hline 12 & 8,8 & 3660 & 3980 & 35 & 0,0064 & 3 & 0 & 87 & 72 & 96,2 \\
\hline 13 & 8,6 & 3470 & 4100 & 37 & 0,0063 & 3 & 0 & 87 & 72 & 96,3 \\
\hline 14 & 8,6 & 3530 & 4020 & 40 & 0,0062 & 2 & 0 & 87 & 72 & 97,4 \\
\hline 15 & 8,7 & 3560 & 3560 & 35 & 0,0071 & 3 & 0 & 87 & 72 & 96,2 \\
\hline 16 & 8,6 & 3500 & 3120 & 30 & 0,0081 & 2 & 0 & 87 & 72 & 97,4 \\
\hline 17 & 8,7 & 3120 & 3790 & 34 & 0,0073 & 2 & 0 & 88 & 72 & 97,6 \\
\hline 18 & 8,7 & 3290 & 4200 & 35 & 0,0063 & 2 & 0 & 87 & 72 & 97,5 \\
\hline 19 & 8,6 & 3370 & 3910 & 40 & 0,0068 & 2 & 0 & 88 & 72 & 97,6 \\
\hline 20 & 8,7 & 3090 & 4120 & 42 & 0,0065 & 2 & 0 & 87 & 72 & 97,6 \\
\hline & & & & & & & & & Continua
\end{tabular}


Fase Aerada

Final da etapa aerada

\begin{tabular}{|c|c|c|c|c|c|c|c|c|c|c|}
\hline Ciclo & $\mathrm{pH}$ & $\begin{array}{c}\text { Alcalinidade } \\
\text { Total }(\mathrm{mg} / \mathrm{L} \\
\left.\mathrm{CaCO}_{3}\right)\end{array}$ & $\begin{array}{c}\text { SSV } \\
\text { (mg/L) }\end{array}$ & $\begin{array}{l}\text { DBO } \\
(\mathrm{mg} / \mathrm{L})\end{array}$ & $\begin{array}{l}\text { Tempo } \\
\text { da } \\
\text { etapa } \\
\text { (h) }\end{array}$ & $\begin{array}{l}\text { Nitrito } \\
\text { (mg/L) }\end{array}$ & $\begin{array}{l}\text { Nitrato } \\
(\mathrm{mg} / \mathrm{L})\end{array}$ & $\begin{array}{l}\mathrm{N}-\mathrm{NH}_{3} \\
(\mathrm{mg} / \mathrm{L})\end{array}$ & $\begin{array}{c}\text { Taxa de } \\
\text { Nitrificação } \\
\text { (Kg N-NH} H_{3} / \\
\text { Kg }\end{array}$ & $\begin{array}{c}\text { Eficiência } \\
\text { na } \\
\text { remoção } \\
\text { de } \mathrm{N}-\mathrm{NH}_{3}\end{array}$ \\
\hline
\end{tabular}
SSV.dia) (\%)

\begin{tabular}{lllllllllll}
\hline 1 & 8,3 & 3360 & 3360 & 15 & 10 & 69 & 14 & 2 & 0,061 & 97,7 \\
\hline 2 & 8,3 & 3570 & 3570 & 15 & 10 & 82 & 0 & 3 & 0,057 & 96,6 \\
\hline 3 & 8,3 & 2720 & 2720 & 15 & 10 & 82 & 0 & 3 & 0,075 & 96,6 \\
\hline 4 & 8,2 & 2580 & 2580 & 20 & 10 & 82 & 0 & 2 & 0,080 & 97,7 \\
\hline 5 & 8,2 & 2390 & 2390 & 15 & 10 & 83 & 0 & 3 & 0,085 & 96,6 \\
\hline 6 & 8,3 & 2560 & 2560 & 15 & 10 & 82 & 0 & 2 & 0,080 & 97,7 \\
\hline 7 & 8,2 & 2880 & 2880 & 15 & 10 & 82 & 0 & 3 & 0,071 & 96,6 \\
\hline 8 & 8,3 & 2710 & 2710 & 13 & 10 & 83 & 0 & 2 & 0,076 & 97,7 \\
\hline 9 & 8,3 & 2830 & 2830 & 10 & 10 & 81 & 0 & 2 & 0,072 & 97,7 \\
\hline 10 & 8,3 & 2900 & 2900 & 17 & 10 & 83 & 0 & 2 & 0,070 & 97,7 \\
\hline 11 & 8,2 & 3410 & 3150 & 15 & 10 & 79 & 0 & 3 & 0,064 & 96,6 \\
\hline 12 & 8,3 & 3370 & 2940 & 15 & 10 & 80 & 0 & 2 & 0,069 & 97,7 \\
\hline 13 & 8,3 & 3130 & 3100 & 15 & 10 & 77 & 0 & 2 & 0,066 & 97,7 \\
\hline 14 & 8,2 & 3250 & 3120 & 16 & 10 & 79 & 0 & 3 & 0,065 & 96,6 \\
\hline 15 & 8,2 & 3260 & 2750 & 15 & 10 & 78 & 0 & 3 & 0,073 & 96,6 \\
\hline 16 & 8,3 & 3240 & 3110 & 15 & 10 & 85 & 0 & 3 & 0,065 & 96,6 \\
\hline 17 & 8,2 & 2840 & 2890 & 10 & 10 & 81 & 0 & 2 & 0,071 & 97,7 \\
\hline 18 & 8,2 & 2950 & 3110 & 10 & 10 & 82 & 0 & 3 & 0,065 & 96,6 \\
\hline 19 & 8,3 & 3000 & 2760 & 15 & 10 & 82 & 0 & 3 & 0,074 & 96,6 \\
\hline 20 & 8,1 & 2890 & 3120 & 10 & 10 & 79 & 0 & 2 & 0,065 & 97,7 \\
\hline & & & & & & & & & & 0 \\
\hline
\end{tabular}




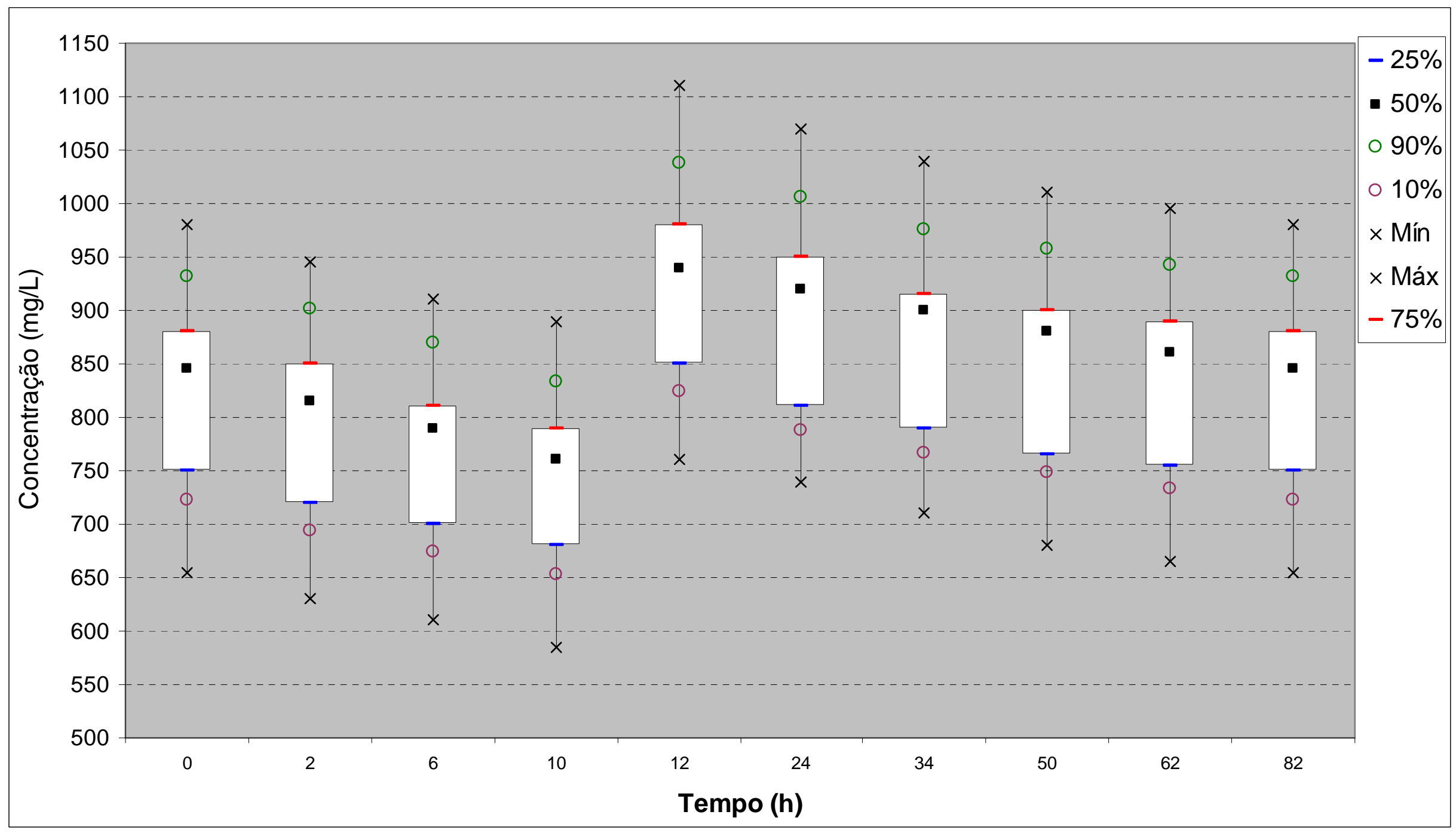

Figura 62 - Perfis das concentrações de COT durante os 10 últimos ciclos de tratamento - Fase 3 
Analisando a tabela 23 nota-se um dos fatos mais relevantes da pesquisa; a matéria orgânica presente no início da fase anóxica não era teoricamente suficiente para a redução de toda a massa de nitrito presente no reator. Nota-se pela tabela 23 que a relação média $\mathrm{DBO}_{\text {removida/Nitrito-Nitrato }}$ removido foi de $0,84 \mathrm{mg} \mathrm{DBO}_{5,20} / \mathrm{mg}\left(\mathrm{N}-\mathrm{NO}_{2}{ }^{-} / \mathrm{N}-\right.$ $\mathrm{NO}_{3}{ }^{-}$); sendo esta a DBO de cinco dias. Considerando a DBO de primeiro estágio uma vez e meia a DBO de cinco dias, tem-se que a relação média

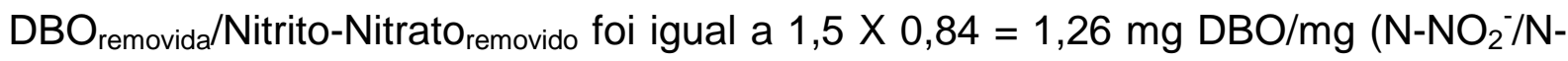
$\mathrm{NO}_{3}{ }^{-}$). Mesmo considerando a DBO de primeiro estágio bem como a parcela referente à respiração endógena, nota-se que a matéria orgânica disponível era insuficiente para a redução do nitrito formado durante a etapa aeróbia. Assim, supõe-se que outros fenômenos, até mesmo químicos, podem ter ocorrido durante a etapa anóxica e contribuído para a redução do nitrito. Outra possível explicação para tal redução é que a matéria orgânica recalcitrante, que teoricamente não seria assimilável aos microrganismos, pode ter sido utilizada pelos mesmos para a redução do nitrito. Esta quebra da matéria orgânica recalcitrante pode ter se dado de maneira lenta, sendo este um dos possíveis motivos para o longo tempo da etapa anóxica. Esta possível utilização da matéria orgânica recalcitrante pelos microrganismos pode ser um efeito da aclimatação dos mesmos ao efluente lixiviado. AKERMAM (2005) não obteve uma boa desnitrificação quando utilizou o lixiviado como fonte de carbono para o processo de desnitritação, sendo que, a alta concentração de compostos recalcitrantes presente no lixiviado estudado foi um dos motivos apontados para a não redução do nitrito formado durante a etapa aeróbia. A redução da DBO durante os ciclos de tratamento ficou acima de $85 \%$.

A taxa média específica de nitritação foi de $0,070 \mathrm{Kg} \mathrm{N}-\mathrm{NH}_{3} / \mathrm{Kg} \mathrm{SSV}$.dia e a de desnitritação igual a 0,0066 Kg N-NH$/ \mathrm{Kg} \mathrm{SSV.dia.} \mathrm{Nota-se} \mathrm{que} \mathrm{a} \mathrm{taxa} \mathrm{de}$ desnitrificação foi bem menor do que a de nitritação, ou seja, o limitante dos ciclos não foi a concentração de nitrogênio amoniacal do afluente e sim a disponibilidade de matéria orgânica para a redução do nitrito na etapa anóxica. 
5.3.4 FASE 04 - ALIMENTAÇÃO DO SISTEMA COM 4L DE LIXIVIADO PRÉTRATADO ("STRIPPING" DE AMÔNIA ATÉ A CONCENTRAÇÃO DE APROXIMADAMENTE 900 MG/L)

Após 20 ciclos operando com o sistema R-1 em equilíbrio dinâmico optou-se por mudar a fração de alimentação do sistema; ao invés de se usar um volume de alimentação equivalente a $10 \%$ do volume do reator, passou-se a alimentar o reator R-1 com um volume de alimentação equivalente a $20 \%$ do seu volume, ou seja, $4 \mathrm{~L}$. O lixiviado utilizado nesta fase era pré-tratado ("stripping" de amônia).

O primeiro ciclo desta fase foi iniciado com o término da etapa aeróbia do ultimo ciclo da fase anterior, ou seja, a concentração de nitrito no início do primeiro ciclo desta fase era correspondente a concentração de nitrogênio amoniacal do inicio do ciclo aerado da fase anterior. Como houve um aumento da concentração de matéria orgânica disponível para a redução do nitrito devido ao maior volume de alimentação, a fase anóxica deste primeiro ciclo foi mais curta do que a dos ciclos da fase 3. Este fato não se repetiu para os próximos ciclos já que, a formação de nitrito/nitrato na fase aerada também sofreu um aumento devido ao maior volume de alimentação. A figura 64 traz o perfil temporal das concentrações de nitrito, nitrato, $\mathrm{N}-\mathrm{NH}_{3}$, durante o primeiro ciclo de tratamento desta fase. 


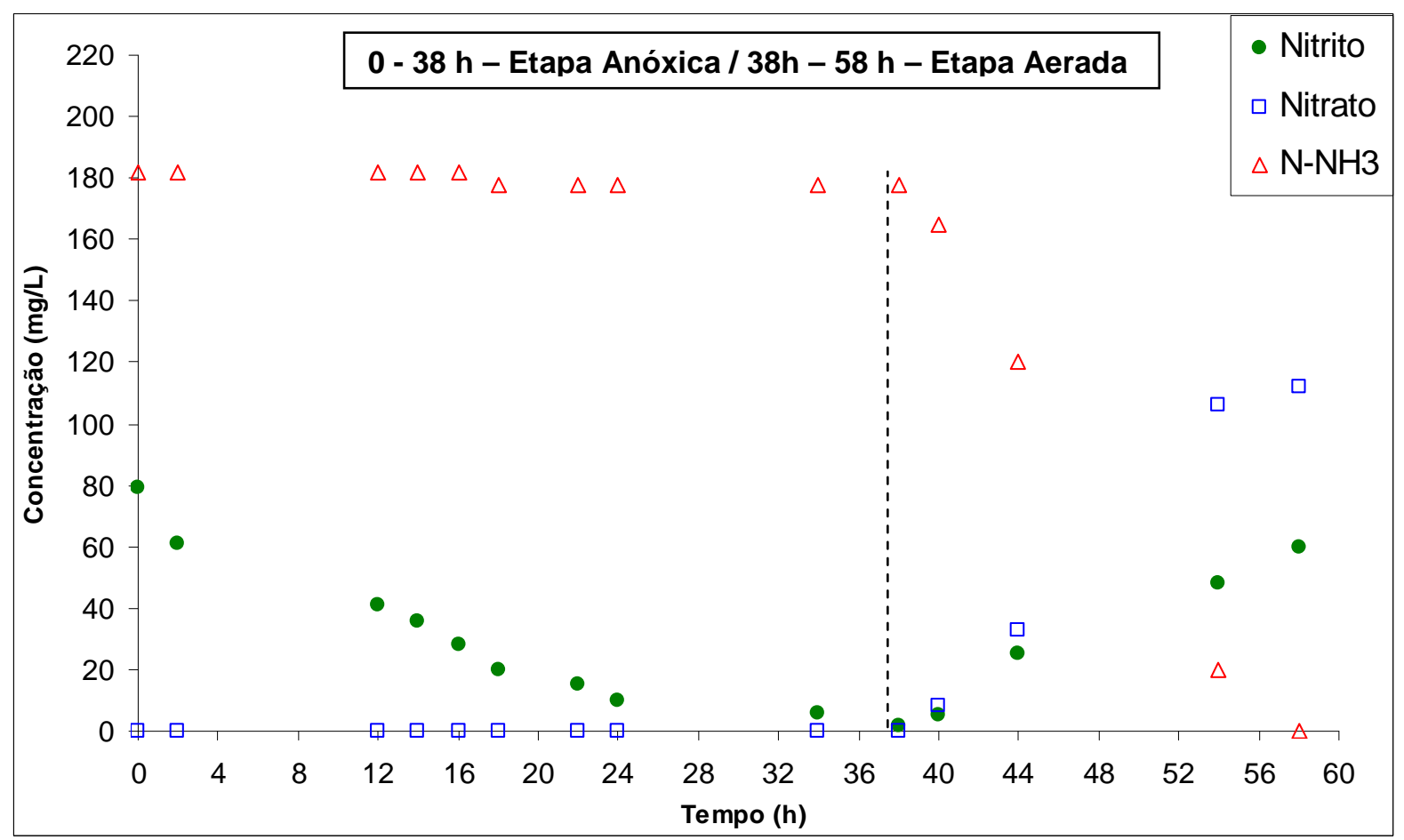

Figura 63 - Perfis temporais das concentrações de $\mathrm{N}_{-} \mathrm{NO}_{2}^{-}, \mathrm{N}_{-} \mathrm{NO}_{3}{ }^{-}$e $\mathrm{N}-\mathrm{NH}_{3}+$ durante o primeiro ciclo de tratamento do reator $\mathrm{R}-1 / \mathrm{Fase} 4$.

Nota-se através da figura 64 que uma parcela significativa da amônia oxidada foi convertida em nitrato, assim como havia ocorrido na 1 e 2 fase da pesquisa. $\mathrm{O} \mathrm{pH}$ da massa líquida, apesar do maior tempo da etapa aeróbia, se manteve acima de 8,3 durante todo o ciclo, porém devido ao não conhecimento do tempo da etapa aerada, o tempo do período aerado foi maior que o necessário o que ocasionou a oxidação de todo o nitrogênio amoniacal no final da etapa aerada. A oxidação de todo o nitrogênio amoniacal durante a etapa aeróbia não possibilitou a manutenção de um residual de amônia livre no reator e conseqüentemente a inibição da nitratação. Mesmo sem um percentual de amônia livre, houve a formação de nitrito provavelmente causada pela aclimatação dos microrganismos obtida na etapa anterior do ciclo. Com o passar dos ciclos, mesmo com a manutenção de residuais de amônia livre no final da etapa aeróbia, houve a formação de nitrato durante a etapa aeróbia sendo que, esta formação foi reduzida gradualmente ao longo dos ciclos até inibição total da nitratação. As figuras 65 e 66 trazem os perfis das concentrações de $\mathrm{N}-\mathrm{NO}_{3}{ }^{-}, \mathrm{N}-\mathrm{NO}_{2}{ }^{-}$e N-NH${ }_{3}$ durante os ciclos que se seguiram. 


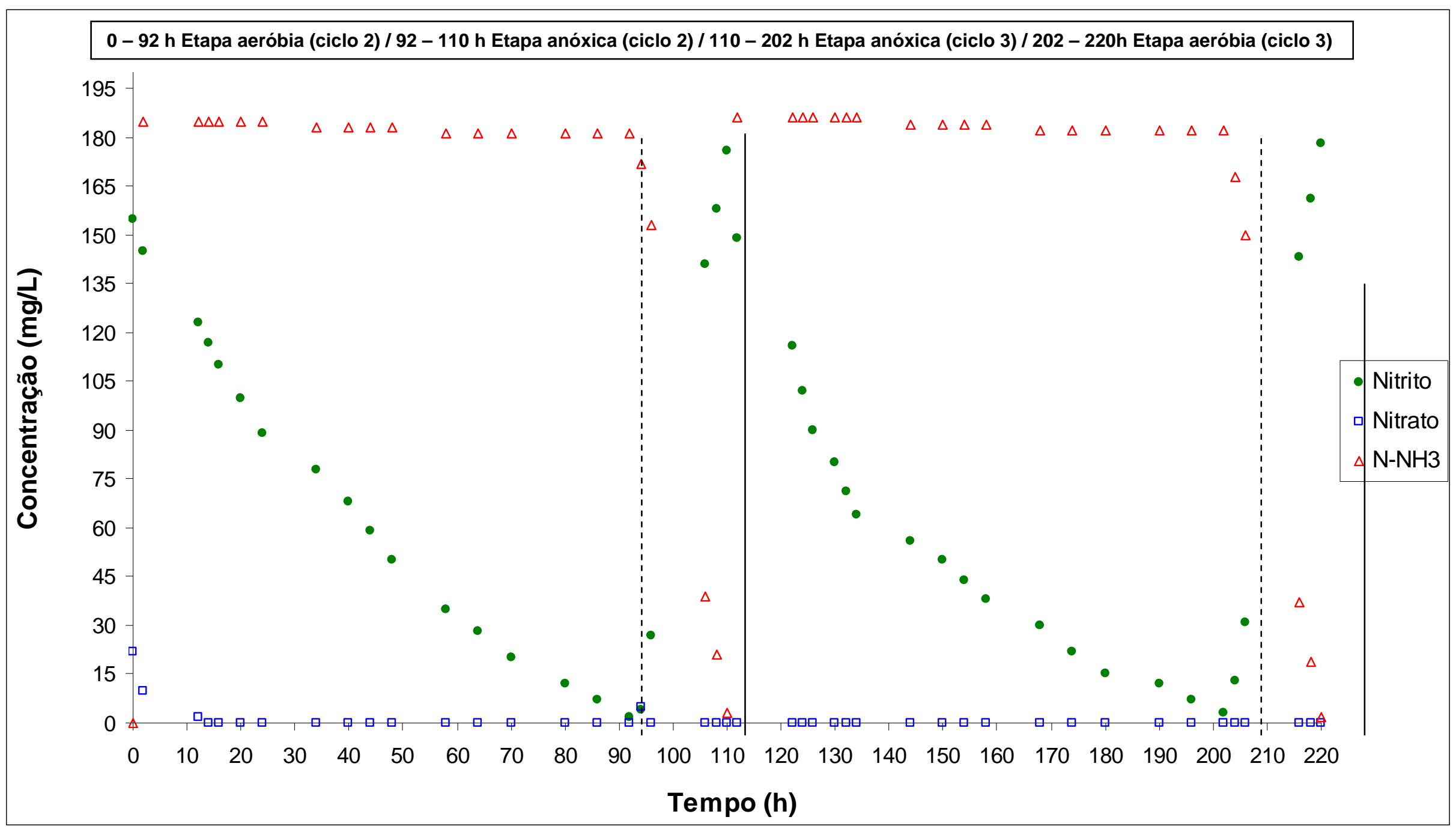

Figura 64 - Perfis temporais das concentrações de $\mathrm{N}-\mathrm{NO}_{2}{ }^{-}, \mathrm{N}-\mathrm{NO}_{3}{ }^{-}$e N-NH${ }_{3}+$ durante os dois ciclos seguintes de tratamento do reator $\mathrm{R}-1 / \mathrm{Fase} 4$. 


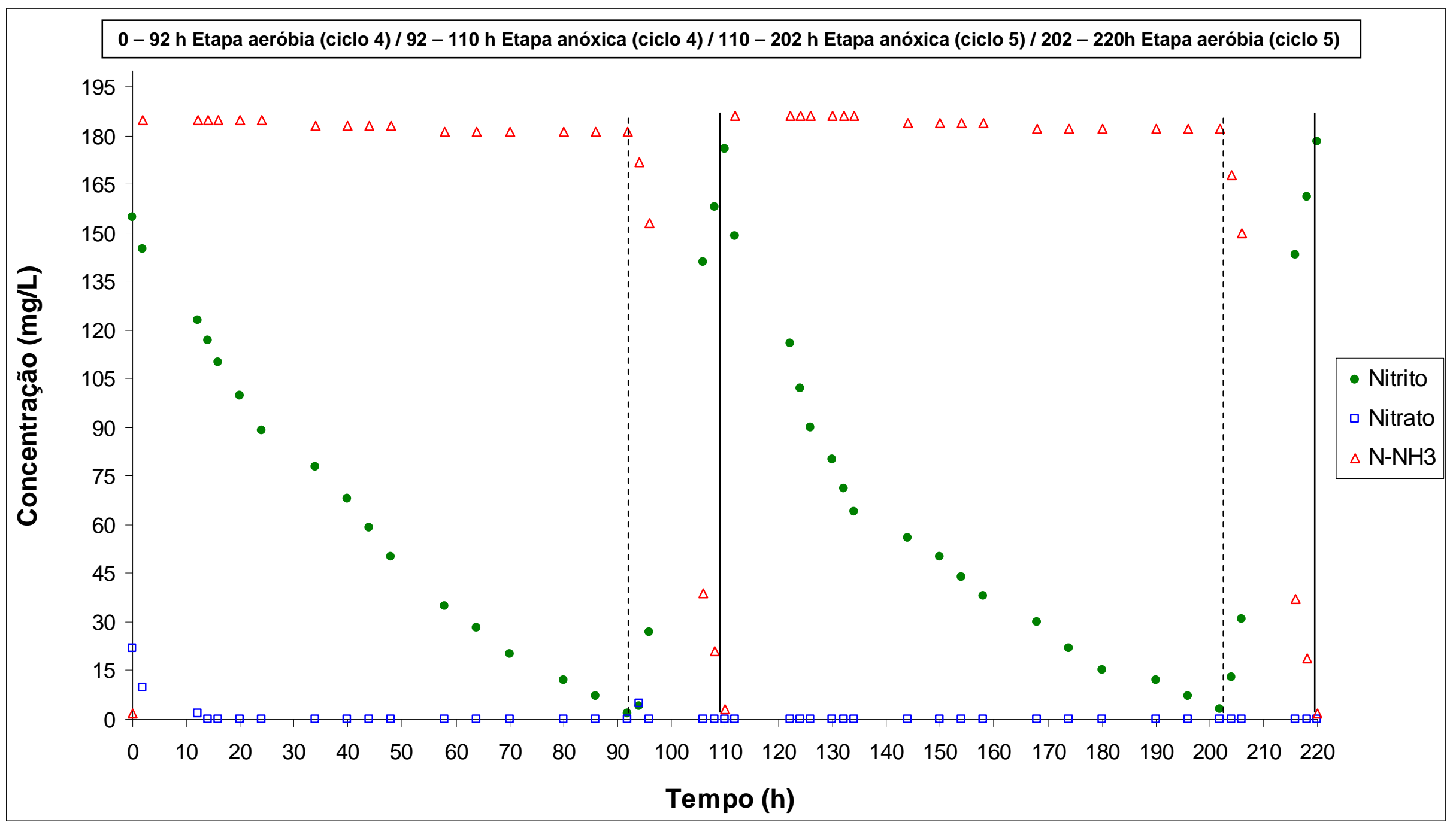

Figura 65- Perfis temporais das concentrações de $\mathrm{N}_{-} \mathrm{NO}_{2}^{-}, \mathrm{N}_{-}-\mathrm{NO}_{3}{ }^{-}$e N-NH${ }_{3}+$ durante os dois ciclos finais de tratamento do reator $\mathrm{R}-1 /$ Fase 4. 
Nota-se através das figuras 65 e 66 que com o passar do tempo as concentrações de nitrato no reator diminuíram sendo que nos últimos dois ciclos a relação $\mathrm{N}-\mathrm{NH}_{3} /$ $\left(\mathrm{N}-\mathrm{NO}_{2}{ }^{-}+\mathrm{N}-\mathrm{NO}_{3}{ }^{-}\right)$ficou acima de $90 \%$ demonstrando assim um acúmulo eficiente de nitrito.

A tabela 24 traz as características físico-químicas e as taxas referentes aos 5 ciclos de tratamento desta fase.

Tabela 24 - Características físico-químicas e taxas referentes aos 5 ciclos de tratamento utilizando o sistema R-1 (quarta fase).

Fase Anóxica

Inicio da etapa anóxica (após alimentação)

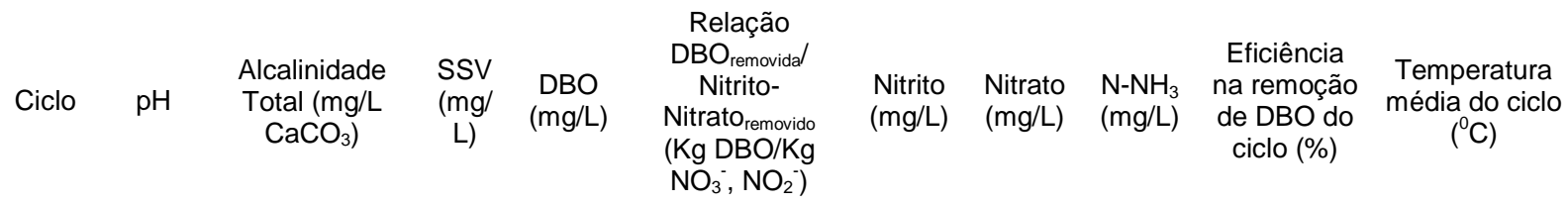

\begin{tabular}{ccccccccccc}
\hline 1 & 8,6 & 3850 & 4180 & 250 & 2,43 & 79 & 0 & 182 & 90,0 & 24 \\
\hline 2 & 8,5 & 4100 & 3530 & 220 & 0,90 & 60 & 112 & 186 & 90,9 & 23 \\
\hline 3 & 8,3 & 3800 & 4110 & 245 & 0,96 & 122 & 58 & 185 & 93,9 & 22 \\
\hline 4 & 8,4 & 3550 & 4150 & 260 & 0,97 & 155 & 22 & 185 & 92,3 & 24 \\
\hline 5 & 8,4 & 3400 & 3930 & 220 & 0,84 & 176 & 0 & 186 & 90,9 & 25 \\
\hline \multicolumn{8}{c}{ Final da etapa anóxica = Início da etapa aerada } \\
\hline
\end{tabular}

\begin{tabular}{|c|c|c|c|c|c|c|c|c|c|c|}
\hline Ciclo & $\mathrm{pH}$ & $\begin{array}{c}\text { Alcalinidade } \\
\text { Total }(\mathrm{mg} / \mathrm{L} \\
\left.\mathrm{CaCO}_{3}\right)\end{array}$ & $\begin{array}{c}\text { SSV } \\
\text { (mg/ } \\
\text { L) }\end{array}$ & $\begin{array}{c}\mathrm{DBO} \\
(\mathrm{mg} / \mathrm{L})\end{array}$ & $\begin{array}{c}\text { Taxa de } \\
\text { Desnitrificação } \\
\text { (Kg NO3--, NO2- } \\
\text { / Kg SSV.dia) }\end{array}$ & $\begin{array}{l}\text { Nitrito } \\
\text { (mg/L) }\end{array}$ & $\begin{array}{l}\text { Nitrato } \\
(\mathrm{mg} / \mathrm{L})\end{array}$ & $\begin{array}{l}\mathrm{N}-\mathrm{NH}_{3} \\
(\mathrm{mg} / \mathrm{L})\end{array}$ & $\begin{array}{l}\text { Tempo da } \\
\text { etapa }(\mathrm{h})\end{array}$ & 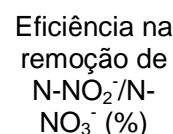 \\
\hline
\end{tabular}

\begin{tabular}{ccccccccccc}
\hline 1 & 8,7 & 4050 & 4100 & 70 & 0,0114 & 2 & 3 & 178 & 38 & 93,7 \\
\hline 2 & 8,7 & 4310 & 4130 & 65 & 0,0109 & 0 & 0 & 182 & 92 & 100,0 \\
\hline 3 & 8,6 & 4050 & 4020 & 75 & 0,0116 & 2 & 0 & 181 & 92 & 98,9 \\
\hline 4 & 8,6 & 3760 & 4110 & 90 & 0,0111 & 2 & 0 & 181 & 92 & 98,9 \\
\hline 5 & 8,7 & 3620 & 3850 & 75 & 0,0117 & 3 & 0 & 182 & 92 & 98,3 \\
\hline \multicolumn{8}{c}{ Fase Aerada } \\
\hline \multicolumn{10}{c}{ Final da etapa aerada }
\end{tabular}

\begin{tabular}{|c|c|c|c|c|c|c|c|c|c|c|}
\hline íclo & $\mathrm{pH}$ & $\begin{array}{c}\text { Alcalinidade } \\
\text { Total }\left(\mathrm{mg}^{\prime} / \mathrm{L}\right. \\
\left.\mathrm{CaCO}_{3}\right)\end{array}$ & $\begin{array}{l}\text { SSV } \\
(\mathrm{mg} / \\
\mathrm{L})\end{array}$ & $\begin{array}{l}\text { DBO } \\
(\mathrm{mg} / \mathrm{L})\end{array}$ & $\begin{array}{l}\text { Tempo da etapa } \\
\text { (h) }\end{array}$ & $\begin{array}{l}\text { Nitrito } \\
\text { (mg/L) }\end{array}$ & $\begin{array}{l}\text { Nitrato } \\
(\mathrm{mg} / \mathrm{L})\end{array}$ & $\begin{array}{l}\mathrm{N}-\mathrm{NH}_{3} \\
(\mathrm{mg} / \mathrm{L})\end{array}$ & 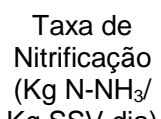 & $\begin{array}{c}\text { Eficiência na } \\
\text { remoção de } \\
\mathrm{N}-\mathrm{NH}_{3}(\%)\end{array}$ \\
\hline
\end{tabular}

\begin{tabular}{cccccccccccc}
\hline 1 & 8,3 & 3910 & 3480 & 25 & 20 & 60 & 112 & 0 & 0,061 & 100,0 \\
\hline 2 & 8,2 & 4110 & 3770 & 20 & 18 & 122 & 58 & 3 & 0,063 & 98,4 \\
\hline 3 & 8,3 & 3830 & 3210 & 15 & 18 & 155 & 22 & 2 & 0,074 & 98,9 \\
\hline 4 & 8,2 & 3550 & 3910 & 20 & 18 & 176 & 0 & 3 & 0,061 & 98,3 \\
\hline 5 & 8,3 & 3410 & 4100 & 20 & 18 & 178 & 0 & 2 & 0,059 & 98,9 \\
\hline
\end{tabular}


Através da tabela 24 pode-se observar que, com exceção do primeiro ciclo, a relação média $\mathrm{DBO}_{\text {removida/Nitrito-Nitrato }}$ removido ficou abaixo de $1,0 \mathrm{mg} \mathrm{DBO}{ }_{5,2} / \mathrm{mg}(\mathrm{N}$ $\mathrm{NO}_{2}{ }^{-} / \mathrm{N}^{-} \mathrm{NO}_{3}{ }^{-}$). Esta relação foi maior no primeiro ciclo já que, o nitrito formado era provindo da etapa anterior e a disponibilidade de matéria orgânica neste ciclo era maior devido ao maior volume de alimentação.

Mais uma vez pode-se observar que a quantidade de matéria orgânica utilizada durante a etapa anóxica do ciclo era menor do que a teoricamente necessária para a redução de todo o nitrito/nitrato presente no reator. Este fato associado a parcela de matéria orgânica recalcitrante presente no lixiviado fez com que os tempos da etapa anóxica dos ciclos continuassem relativamente altos (acima de $90 \mathrm{~h}$ para os ciclos 2 , 3,4 e 5). Nota-se que quando a disponibilidade de matéria orgânica foi maior (ciclo 1), em relação a quantidade de nitrito formado, o tempo da etapa anóxica foi mais curto do que nos ciclos posteriores da fase 4 .

A amônia livre durante os últimos quatro ciclos de tratamento desta fase variou entre 0,203 (final etapa aeróbia) a $49 \mathrm{mg} / \mathrm{L}$ (inicio etapa aeróbia) valores estes considerados inibidores para as bactérias nitratantes. No final da etapa aeróbia do primeiro ciclo a concentração de amônia livre no reator foi igual a zero, sendo este um dos possíveis motivos para a formação de uma concentração maior de nitrato do que de nitrito durante este ciclo. Nos ciclos que se seguiram ainda houve a conversão de $\mathrm{N}^{-\mathrm{NH}_{3}}$ em nitrato. $\mathrm{O}$ aparecimento de nitrato nos ciclos que se seguiram pode ser em função da aclimatação dos microrganismos as novas condições operacionais já que, com o passar dos ciclos esta concentração foi diminuindo até não ser possível mais detectar concentrações de nitrato na massa líquida.

Assim como em todas as etapas da pesquisa, houve uma recuperação de alcalinidade durante a etapa aeróbia dos ciclos de tratamento. Nesta fase a recuperação média de alcalinidade foi igual a $1,56\left(\mathrm{mg} / \mathrm{L} \mathrm{CaCO}{ }_{3}\right) /\left(\mathrm{mg} / \mathrm{LN}-\mathrm{NO}_{2}{ }^{-} / \mathrm{N}-\right.$ $\mathrm{NO}_{3}{ }^{-}$. 


\section{CONCLUSÕES}

Através da presente pesquisa pode-se concluir que:

- O processo de "stripping" ocasionou não somente a redução da concentração de nitrogênio amoniacal mais também a redução de DQO, DBO e COT tanto para o sistema utilizando aeração por bolhas grossas como para o sistema com agitação mecânica.

- O processo de "stripping" por aeração com bolhas grossas foi mais eficiente na remoção de DQO, COT e DBO, isso se deu provavelmente pelo fato de o ar introduzido no sistema propiciar um maior arraste de compostos orgânicos voláteis.

- O pré-tratamento por "stripping" fez com que o pH da massa líquida aumentasse ao longo do ciclo ao contrário da alcalinidade que decaiu ao longo do mesmo.

- As taxas médias de remoção de amônia quando se utilizou o sistema por agitação mecânica variaram entre 83,14 e $86,95 \mathrm{mg} \mathrm{N}-\mathrm{NH}_{3} / \mathrm{L}$.dia. Já para o sistema por aeração com bolhas grossas a taxa média de remoção de amônia ficou entre 78 e $79,26 \mathrm{mg} \mathrm{N}-\mathrm{NH}_{3} / \mathrm{L}$.dia.

- Nas primeiras fases da pesquisa utilizando o sistema R-1 as concentrações de amônia livre variando entre 20,7 e 0,23 mg/L não inibiram completamente a nitratação.

- Para a alimentação do sistema R-2 utilizando lixiviado pré-tratado ("stripping" de amônia até a concentração de aproximadamente $900 \mathrm{mg} / \mathrm{L}$ ) as condições para o acúmulo de nitrito foram: manutenção do $\mathrm{pH}$ acima de 8,3 associado a manutenção da concentração de amônia livre no reator acima de $0,1 \mathrm{mg} / \mathrm{L}$. Para esta condição a relação $\mathrm{N}-\mathrm{NO}_{2}{ }^{-} /\left(\mathrm{N}-\mathrm{NO}_{2}{ }^{-}+\mathrm{N}-\mathrm{NO}_{3}{ }^{-}\right)$durante a pesquisa foi maior que $95 \%$.

- Mantendo uma concentração de aproximadamente $1,0 \mathrm{mg} / \mathrm{L} \mathrm{O}_{2}$ no reator durante a etapa aerada, a remoção de nitrogênio amoniacal foi acima de 95\% em todas as fases da pesquisa. 
- Na primeira fase, para uma concentração de SSV no reator entre $4250 \mathrm{mg} / \mathrm{L}$ e $3690 \mathrm{mg} / \mathrm{L}$, a taxa específica de nitrificação variou entre 0,042 e $0,048 \mathrm{Kg} \mathrm{N}$ $\mathrm{NH}_{3} / \mathrm{Kg}$ SSV.dia. Na fase 2 para um concentração de SSV entre 3550 e 3830 $\mathrm{mg} / \mathrm{L}$, a taxa específica de nitrificação variou entre 0,038 e 0,046 $\mathrm{Kg} \mathrm{N}-\mathrm{NH}_{3} /$ $\mathrm{Kg}$ SSV.dia. Na fase 3, para uma concentração média de SSV no reator igual a $2930 \mathrm{mg} / \mathrm{L}$ a taxa específica média de nitrificação foi de $0,070 \mathrm{Kg} \mathrm{N}-\mathrm{NH}_{3} / \mathrm{Kg}$ SSV.dia. Por fim na fase 4 para uma concentração de SSV entre 3400 e 4310 $\mathrm{mg} / \mathrm{L}$ a taxa de desnitritação variou entre 0,059 e $0,074 \mathrm{Kg} \mathrm{N}-\mathrm{NH}_{3} / \mathrm{Kg}$ SSV.dia.

- A etapa anóxica do ciclo em todas as fases da pesquisa e em específico na terceira fase, foi condicionada pela disponibilidade de matéria orgânica disponível para a redução do nitrato. A redução da matéria orgânica durante o "stripping" associada a grande parcela de compostos recalcitrantes fez com que a etapa anóxica do ciclo fosse relativamente longa.

- Em todas as fases da pesquisa a relação média $\mathrm{DBO}_{\text {removida/Nitrito- }}$

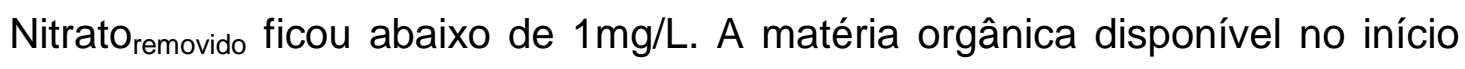
da etapa anóxica teoricamente não era suficiente para a redução de todo o nitrito formado durante a etapa aeróbia sendo que, possivelmente, outros fenômenos contribuíram para a redução do nitrito durante a etapa anóxica.

- Em todas as fases da pesquisa houve uma recuperação de alcalinidade durante a etapa anóxica. A recuperação média de alcalinidade variou entre 1,41 (fase 1) e 2,36 (mg/L CaCO 3$) /\left(m g / L N-\mathrm{NO}_{2}{ }^{-} / \mathrm{N}^{-} \mathrm{NO}_{3}{ }^{-}\right.$) (fase 2). 


\section{SUGESTÕES PARA PRÓXIMAS PESQUISAS}

Para futuras pesquisas objetivando a remoção biológica de nitrogênio de lixiviado utilizando o mesmo como fonte de carbono para a etapa anóxica, bem como futuras pesquisas visando a remoção de nitrogênio amoniacal através do processo de "stripping" recomenda-se:

- Variação da vazão de ar para o processo de "stripping" por aeração, obtendo assim várias taxas de remoção para diferentes vazões de ar.

- Estudo dos fenômenos que provocam o decaimento da DQO, DBO e COT durante o "stripping", já que nesta pesquisa não é possível precisar qual o principal agente responsável por esta redução.

- Controle da temperatura no processo de acúmulo de nitrito e desnitrificação, objetivando verificar a variação das taxas de nitrificação e desnitrificação para diferentes faixas de temperatura.

- Estudo da utilização da matéria orgânica disponível para a redução do nitrito na etapa anóxica, com o objetivo de determinar qual a parcela de matéria orgânica é realmente utilizada pelos microrganismos redutores de nitrato ou então se esta redução se dá por algum outro fenômeno. 


\section{BIBLIOGRAFIA}

AGDAG, O. N.; SPONZA D. T. Anaerobic/aerobic treatment of municipal landfill leachate in sequential two-stage up-flow anaerobic sludge blanket reactor (UASB)/completely stirred tank reactor (CSTR) systems. Process Biochemistry, n.40, p. 895-902, 2005.

AMARAL, M. C. S.; FERREIRA, C. F .A. LENGEL, L. C.; AQUINO, S. F. Avaliação da biodegradabilidade anaeróbia de lixiviados de aterro sanitários. Engenharia Sanitária e Ambiental, vol.13, n.1, 2008.

AMERICAN PUBLIC HEALTH ASSOCIATION (APHA), AMERICAN WATER WORKS ASSOCIATION (AWWA), and WATER ENVIRONMENT FEDERATION (WEF). Standard methods for examination of water and wastewater. 20 ed., Washington, 1998.

AKERMAM, A. Feasibility of nitrate-shunt (nitritation) on landfill leachate. Tese (Mestrado) - Instituto de Tecnologia, Universidade de Lund (Suécia), 2005. Disponível em http://www.sysav.se/upload/ovright. Acesso em 14 out. de 2007).

AMOKRANE, A.; COMEL,C; VERON, J. Landfill leachates pretreatment by coagulation-flocculation. Water Research, vol.31, n.11, p.2775-2782, 1997.

ANTHONISEN, A. C., LOEHR R. C.; PRAKASAM T.B.S.; SRINATH, E. G. Inhibition of nitrification by ammonia and nitrous acid. Journal of Water Pollution Control Federation, v.48, n.5, p.835-852, 1976.

ASSIS, J. F. Avaliação do uso de aterros como alternativa para disposição de resíduos sólidos domiciliares e industriais. 1999. 126 p. Dissertação (Mestrado) Escola de Engenharia de São Carlos, Universidade de São Paulo. São Carlos, 1999.

BERGE, N. D.; REINHART, D. R.; BATARSEH, E. S. Strategy for complete nitrogen removal in bioreactor landfills. Journal of Environmental Engineering, vol.133, n.12, p. 1117-1125, 2007.

BIDONE, R. F.; HARTMANN, F.; ROSA, A. L.; SOUTO, G. B; POVINELL, J. I. Filtros anaeróbios aplicados ao tratamento de lixiviado de aterro sanitário. In: CONGRESSO BRASILEIRO DE ENGENHARIA SANITÁRIA E AMBIENTAL, 24.,2007, Belo Horizonte. Anais. Belo Horizonte: ABES. 1990 p.1-8.

BOCK, E.; SCHMIDT, R. S.; ZART D. Nitrogen loss caused by denitrifying Nitrosomonas cells using ammonium or hydrogen as electron acceptor. Archive Microbiology, v.12 p.16-20, 1995.

BRASIL. Instituto Brasileiro de Geografia e Estatística. Pesquisa de informações básicas municipais: relatório final 2002. Rio de Janeiro:IBGE, 2005. 382 p. 
BRASIL. Instituto Brasileiro de Geografia e Estatística. Pesquisa nacional de saneamento básico: relatório final 2000. Rio de Janeiro:IBGE, 2002. 397 p.

BRASIL. Ministério do Meio Ambiente. Conselho Nacional do Meio Ambiente. Resolução nO 357 de 17 de março de 2005. Dispõe sobre a classificação dos corpos de água e diretrizes ambientais para o seu enquadramento, bem como estabeleçe as condições e padrões de lançamento de efluentes, e dá outras providências. Diário Oficial da União, 18 mar. 2005.

CASTILLO, E.; VERGARA, M.; MORENO, Y. Landfill leachate treatment using a rotating biological contactor and an upward-flow anaerobic sludge bed reactor. Waste Management, n.27, p.720-726, 2007.

ÇEÇEN, F.; ÇAKIROGLU, D. Impact of landfill leachate on the co-treatment of domestic wastewater. Biotechnology Letters, n.23, p.821-826, 2001.

CHANG, J. Treatment of landfill leachate with an upflow anaerobic reactor combining a sludge bed and a filter. Water Science \& Technology, Londres v. 21, n.4-5, p. 133-143, 1989.

CHEUNG K. C.; CHU L. M. ; WONG M. H.; Ammonia stripping as a pretreatment for landfill leachate. Water, air and soil pollution, vol. 94, n.1-2, p. 209-221,1997.

CHIANESE, A.; RANAURO, R.; VERDONE, N. Treatment of landfill leachate by reverse osmosis. Water Research, vol.33, n.3, p.647-652, 1998.

CIUDAD, G.; GONZÁLEZ, R., BORNHARDT, C.; ANTILEO, C. Modes of operation and $\mathrm{pH}$ control as enhancement factors for partial nitrification with oxygen transport limitation. Water Research, n.4, p.4621-4629, 2007.

FUX, C.; SIEGRIST, $H$. Nitrogen removal from sludge digester liquids by nitrification/denitrification or partial nitritation/anammox:environmental and economical considerations. Water Science and Technology, vol. 50, n.10, p.19-26, 2004.

GANIGUÉ, R.; LÓPEZ, H.; BALAGUER, M. D.; COLPRIM, J. Partial ammonium oxidation to nitrite of high ammonium content urban landfill leachates. Water Research, n.41, p. 3317-3326, 2007.

GARRIDO, J. M.; VAN BENTHUM, W.A.J.; VAN LOOSDRECHT, M.C.M.; HEIJNEN, J. J. Influence of dissolved oxygen concentration on nitrite accumulation in o biofilm airlift suspension reactor. Biotechnology and Bioengineering, v.53, p.168-178, 1996.

GÓRSKA, S. J.; CICHON, A.; MIKSCH, C. Nitrogen removal from wastewater with high ammonia nitrogen concentration via shorter nitrification and denitrification. Water Science and technology, Londres, v.36, n.10, p.73-78, 1997. 
Hem, L.J.; Rusten, B.; Oedegaard, H. Nitrification in a moving bed biofilm reactor. Water Research, v.28, n. 6, p. 1425-1433, 1994.

IM, J.; WOO H.; CHOI, M.; HAN, K.; KIM, C. Simultaneous organic and nitrogen removal from municipal landifill leachate using an anaerobic-aerobic system. Water Research, vol.35, n.10, p.2403-2410, 2001.

JORDÃO, E. P.; PESSÔA, C. A. Tratamento de Esgotos Domésticos. 4 ed. Rio de Janeiro: SEGRAC, 2005.

KETTUNEN, R. H;. RINTALA, J. A. Performance of an on-site UASB reactor treating leachate at low temperature. Water Research, vol.32, n.3, p.537-546, 1998.

KIM, D.; KIM, S. Effect of nitrite concentration on the distribution and competition of nitrite-oxidizing bacteria in nitratation reactor systems and their kinetic characteristics. Water Research, n.40, p.887-894, 2006.

KLIMIUK, E.; KULIKOWSKA, D. Organics removal from landfill leachate and activated sludge production in SBR reactors. Waste Management, n.26, p.11401147, 2006.

KNOX, K. Leachate treatment with nitrification of ammonia . Water Research, vol.19, n.7, p.895-904, 1985.

KUAI, L.; VERSTRAETE, W. Ammonium removal by the oxygen-limited autotrophic nitrification-denitrification system. Applied and Environmental Microbiology, vol.64, n.11, p. 4500-4506, 1998.

LAITINEN, N.; LUONSI, A., VILEN, J. Landfill leachate treatment with sequencing batch reactor and membrane bioreactor. Desalination, n. 191, p. 86-91, 2006.

MADIGAN, M. T., MARTINKO, J. M.; PARKER, J. Brock Biology of Microorganisms. $8^{a}$ edição. New Jersey. Prentice Hall, 1997.

MARTIENSSEN, M.; SCHOPS, R. Biological treatment of leachate from solid waste landfill sites - alterations in the bacterial community during the denitrification process. Water Research, vol. 31, n.5, p.1164-1170, 1997.

MASSUKADO, L. M. Sistema de apoio à decisão:avaliação de cenários de gestão integrada de resíduos sólidos urbanos domiciliares. 2004, 230p. Dissertação( Mestrado) - Universidade Federal de São Carlos. São Carlos, 2004:

McBEAN, E. A.; ROVERS, F. A.; FARQUHAR, G. J. Landfill engineering and design. $1^{\text {a }}$ edição. New Jesey. Prentice Hall, 1995. 
METCALF \& EDDY INC. Wastewater engineering: Treatment and Reuse. Revisão de George Tchobanoglous, Franklin Burton e David Stensel. 4 ed. New York: McGraw-Hill, 2003.

MOSER, G.I.F. Estudo da nitrificação de líquido percolado de aterro sanitário utilizando-se sistemas de lagoa aerada e lodos ativados. 2003. 140p. Dissertação (Mestrado) - Escola Politécnica da Universidade de São Paulo. São Paulo, 2003.

MULDER, J. W.; VAN KEMPEN, R. N-removal by SHARON. Water Quality International, v.2, p. 30-31, 1997.

NECZAJ, E.; OKONIEWSKA, E.; KACPRZAK, M. Treatment of landfill leachate by sequencing batch reactor. Desalination, vol.185, p. 357-362, 2005.

NUNESMAIA, M. F. A gestão de resíduos urbanos e suas limitações. Revista Baiana de Tecnologia - SSA, vol.17, n.1,p.120-129, 2002.

PARKES, S. D.; JOLLEY, D. F.; WILSON, S. R. Inorganic nitrogen transformations in the treatment of landfill leachate with a high ammonium load: A case study. Environmental Monitoring Assessment, vol. 124, p.51-61, 2007.

PARKIM, G. F.; OWEN, W. F. Fundamentals of anaerobic digestion of wastewater sludges. Journal of Environmental Engineering, vol.112, n.5, p.867-920, 1986.

PASCHOALATO, C.F.P.R. Caracterização dos líquidos percolados gerados por disposição de lixo urbano em diferentes sistemas de aterramento. 2000. 97 p. Dissertação (Mestrado). Escola de Engenharia de São Carlos, Universidade de São Paulo. São Carlos, 2000.

PENG, Y. Z.; Chen, Y.; Peng, C.Y.; Liu, M.; Wang, S.Y.; Song, X.Q.; Cui, Y.W. Nitrite accumulation by aeration controlled in sequencing batch reactors treating domestic wastewater. Water Science and Technology, vol.50, n.10, p.35-43, 2004.

PHILIPS, S.; LAANBROEK, H. J.; VERSTRAETE, W. Origin, cause and effects of increased nitrite concentrations in aquatic environments. Reviews in Environmental Science and Biotechnology, n.01, p.115-141, 2002.

PIVELI, R. P.; KATO, M. T. Qualidade das águas e poluição:aspectos físicoquímicos. $1^{a}$ edição. São Paulo: Associação Brasileira de Engenharia Sanitária e Ambiental (ABES). 2006.

QASIM, S. R.; CHIANG, W. Sanitary landifill leachate: generation, control and treatment. Lancaster: Ed.Techonomic publishin. 1994.

QUEIROZ, L. M. Estudo da remoção biológica de nitrogênio via nitrito utilizando fenol como fonte de carbono operando um reator em bateladas 
sequenciais (SBR) em escala piloto. 2006. 198 p. Dissertação (Mestrado) - Escola Politécnica da Universidade de São Paulo. São Paulo, 2006.

RODRÍGUEZ, J.; CASTRILLÓN, L.; MARAÑÓN, E.; SASTRE, H.; FERNÁNDEZ, E. Removal of non-biodegradable organic matter from landfill leachates by adsorption. Water Research, vol.38, p. 3297-3303, 2004.

INSTITUTO DE PESQUISAS TECNOLÓGICAS/CEMPRE. Lixo municipal: manual de gerenciamento integrado. 2. ed. São Paulo: IPT, 2000. 370 p.

SÃO PAULO (Estado) Decreto $\mathrm{n}^{\circ} 8.468$ de 08 de setembro de 1976. Aprova o regulamento da Lei nO 997 de 31 de maio de 1976, que dispõe sobre a prevenção e o controle da poluição do meio ambiente. Legialação estadual: controle de poluição ambiental, São Paulo, CETESB, 1991.

SCHALCH, V. Produção e características do chorume em processo de decomposição do lixo urbano.1994.103 p. Dissertação (mestrado), Escola de Engenharia de São Carlos, Universidade de São Paulo. São Carlos, 1994.

SPENGEL, D. B.; DZOMBAK, D. A. Treatment of landfill leachate with rotating biological contactors: bench-scale experiments. Journal of the Water Pollution Control Federation, vol.63, n.7, p. 971-98, 1991.

TENGRUI, L.; AL-HARBAWI, A. F.; BO, L. M.; JUN, Z.; LONG, X. Y.. Characteristics of nitrogen removal from old landfill leachate by sequencing batch biofilm reactor. American Journal of Applied Sciences, n.4, p.211-214, 2007.

TURK, O.; MAVINIC, D. S. Selective inhibition: a novel concept for removing nitrogen from highly nitrogenous wastes. Environmental Technology Letters, n.8, p.419426, 1987.

UYGUR, A.; KARGI, F. Biological nutrient removal from pre-treated landfill leachate. Journal of Environmental Management, n.71, p. 9-14, 2004.

VAN HAANDEL, A.; MARAIS, G. O comportamento do sistema de lodo ativado teoria e aplicações para projeto e operação. Campina Grande: Epgraf, 1999. 488 p.

VERSTRAETE, W.; PHILIPS, S. Nitrification/denitrification processes and technologies in new contexts. Enviromental Pollution, v.102, p. 717-726, 1998.

VON SPERLING, M. Princípios do tratamento biológico de águas residuárias: lagoas de estabilização. $1^{\mathrm{a}}$ edição. Belo Horizonte:DESA, UFMG. 1996. v.3.

VON SPERLING, M . Princípios do tratamento biológico de águas residuárias: lodos ativados. $2^{\mathrm{a}}$ edição. Belo Horizonte: DESA, UFMG, 2002. 4v. 
WANG, F.; SMITH, D. W.; GAMAL EL-DIN, M. Application of advanced oxidation methods for landfill leachate treatment - A review. Journal Environmental Engineering and Science, vol. 2, p. 413-427, 2003.

WELANDER, U.; HENRYSSOW, T; WELANDER, T. Nitrification of landfill leachate using suspended-carrier biofilm technology. Water Research, vol. 31, n.9, p.23512355, 1997.

WISZNIOWSKI, J.; GÓRSKA, S. J.; ROBERT, D.; WEBER, J. V. The effect of landfill leachate composition on organics and nitrogen removal in an activated sludge system with bentonite additive. Journal Environmental Management, vol.85, p.5968, 2007.

WU, J. J.; WU, C.; MA, H.; CHANG, C. Treatment of landfill leachate by ozone-based advanced oxidation processes. Chemosphere, vol.54, p. 997-1003, 2003. 
